Szegedi Tudományegyetem Természettudományi és Informatikai Kar

Természeti Földrajzi és Geoinformatikai Tanszék

Környezettudományi Doktori Iskola

\title{
TÁJVÁLTOZÁSOK ÉRTÉKELÉSE A DUNA-TISZA KÖZI HOMOKHÁTSÁG EGY KÖRNYEZET- ÉS KLÍMAÉRZÉKENY KISTÁJÁN, AZ ILLANCSON
}

Doktori $(\mathrm{PhD})$ értekezés

\section{LADÁNYI ZSUZSANNA}

Témavezető:

Dr. Rakonczai János

egyetemi docens 


\section{TARTALOMJEGYZÉK}

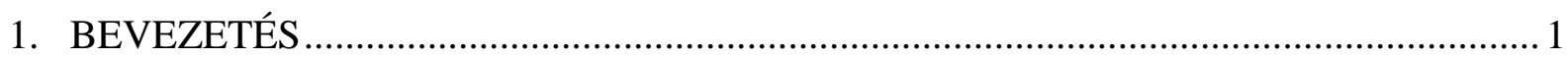

2. AZ ELMÚLT ÉVTIZEDEK TÁJVÁLTOZÁS-KUTATÁSA MAGYARORSZÁGON

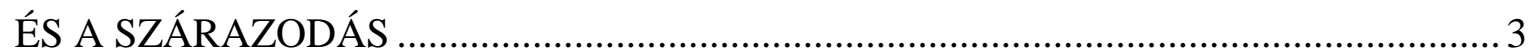

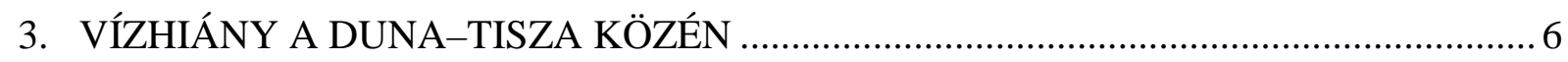

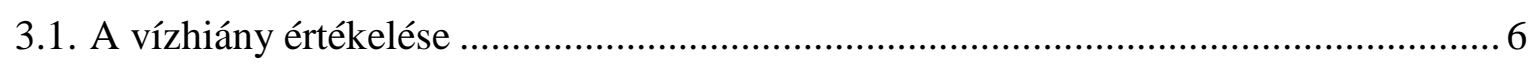

3.2. A Duna - Tisza közi vízhiány probléma kronologikus áttekintése............................. 11

4. A BÁCSKAI-SÍKVIDÉK HOMOKTÁJA, AZ ILLANCS ........................................... 18

4.1. Illancs természetföldrajzi adottságai ................................................................. 18

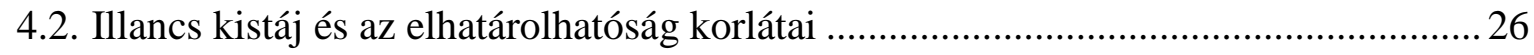

4.2.1. A kistáj elhatárolása a szakirodalomban és annak vitatható pontjai ................26

4.2.2. A kutatás megállapításai a kistáj elhatárolásának pontosításához.................... 29

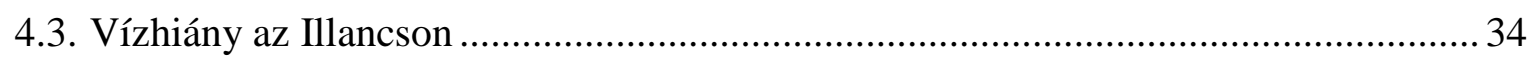

5. AZ ILLANCS TÁJHASZNÁLAT-VÁLTOZÁSAINAK ÉRTÉKELÉSE........................ 37

5.1. Tájhasználat-változások és a Duna-Tisza köze ....................................................... 37

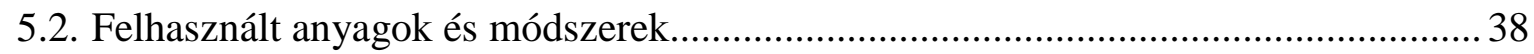

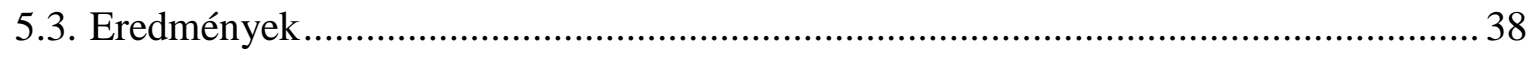

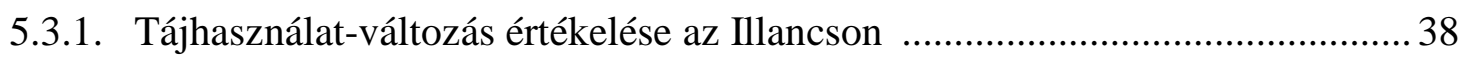

5.3.2. Tájhasználat-változás és a tájhatár összefüggései ....................................... 45

5.3.3. Antropogén környezet-átalakítások az Illancson......................................... 48

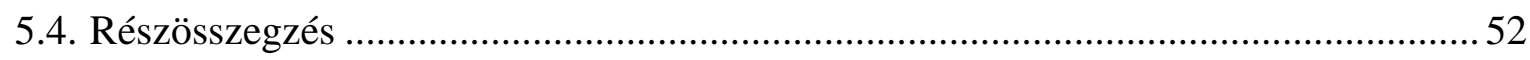

6. AZ ILLANCS TERMÉSZETES ÉLÖHELYEINEK ÁLLAPOTA ÉS VÁLTOZÁSAI

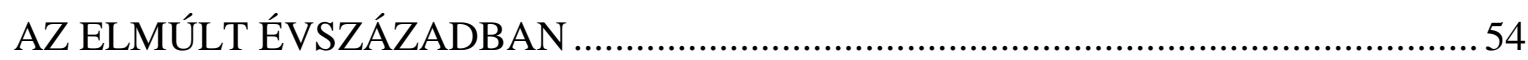

6.1. A Duna-Tisza köze jellemző élöhely-mintázatai és a szárazodás következményei ...54

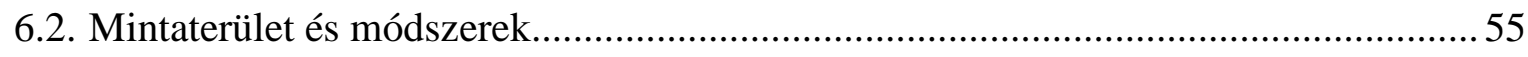

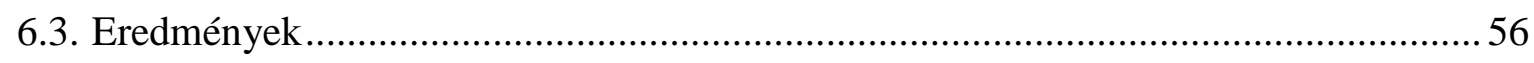

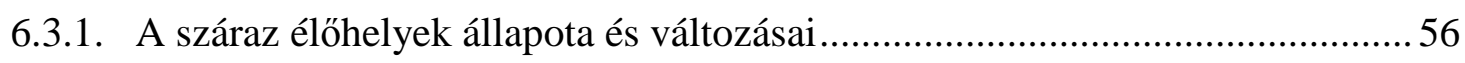

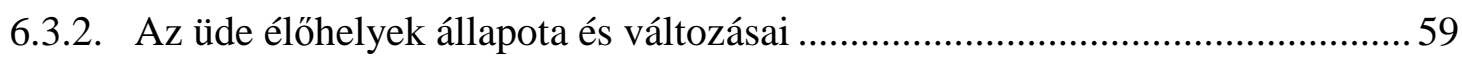

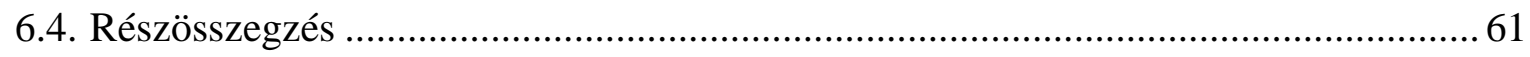

7. A SZÁRAZODÁS KÖVETKEZMÉNYEI EGY BOROTAI VIZES ÉLŐHELY

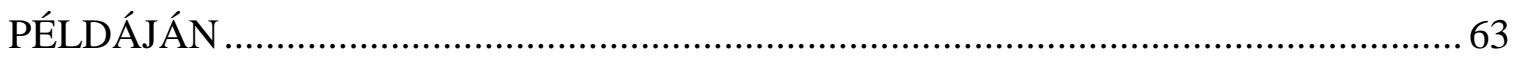

7.1. Buckavonulatok közötti vizes élőhelyek az Illancson............................................... 63

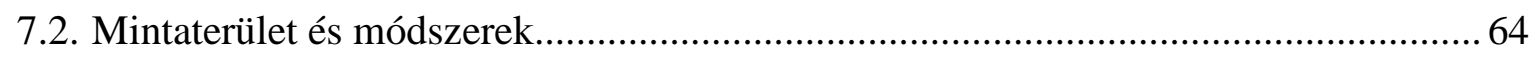




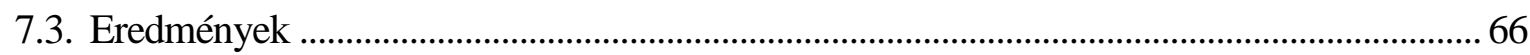

7.3.1. A mintaterület talajtulajdonságainak alakulása napjainkban ......................................... 66

7.3.2. A talajtulajdonságok változása a 20-21. században ..................................................... 70

7.3.3. Aktuális fajkészlet és az élőhelyek változásai a 20-21. században.............................. 73

7.4. Megállapítások a talaj és a vegetáció tekintetében a vizsgált mintaterületen ..............77

8. A TÁJI ÉRZÉKENYSÉG ÉRTÉKELÉSE AZ ILLANCSON TÉRINFORMATIKAI

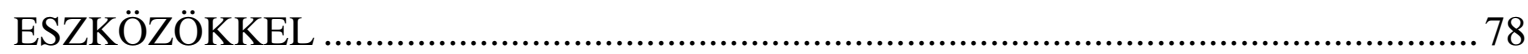

8.1. A spektrális indexek alkalmazása a táji környezet értékelésében ...............................78

8.2. A térinformatikai elemzéshez felhasznált adatok, az előfeldolgozás és az elemzés módszerei, valamint a vizsgált mintaterületek ...................................................... 81

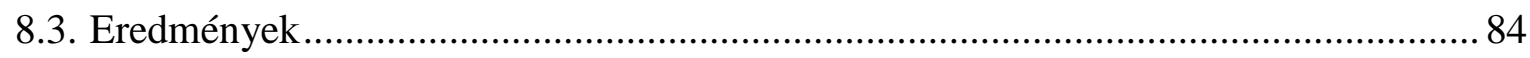

8.3.1. Illancsi telepített erdők biomassza-produkciója és a csapadék kapcsolata....... 84

8.3.2. Kontroll erdőterületek biomassza-produkciója és a csapadék kapcsolata......... 89

8.4. Megállapítások a tájérzékenység térinformatikai értékeléséhez ................................ 91

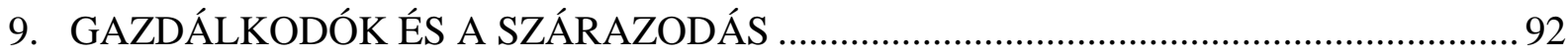

9.1. Illancs és az ember, valamint a szárazodás hatása az illancsi gazdálkodásra .............92 92

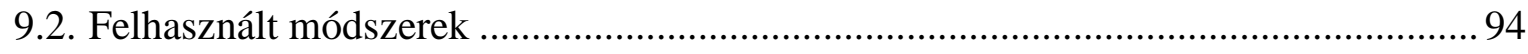

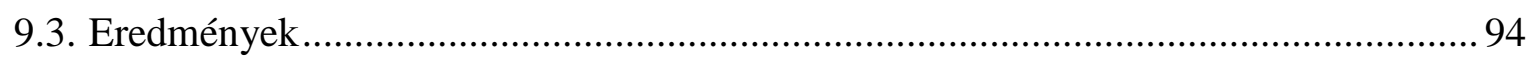

9.4. Alkalmazkodási lehetőségek a szárazodáshoz ........................................................ 98

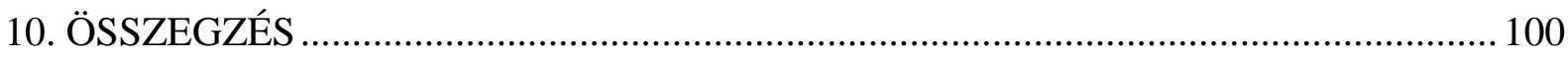

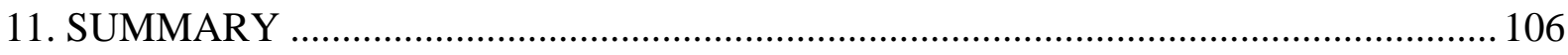

KÖSZÖNETNYILVÁNÍTÁS

IRODALOMJEGYZÉK

MELLÉKLETEK 


\section{BEVEZETÉS}

A globális klímaváltozás kérdésköre napjainkban, a 21. század elején, minden bizonnyal az egyik legtöbbet tárgyalt környezeti problémának tekinthető, melyet számos nemzetközi konferencia, kutatási program, önálló folyóirat és tudományos dolgozat bizonyít, valamint egyre többet szerepel a közmédiákban is. Az Éghajlatváltozási Kormányközi Testület (IPCC) részletes értékelések alapján mára bizonyítottnak látja, hogy olyan klímaváltozásnak vagyunk a részesei, melyben jelentős szerepet játszik az emberiség (IPCC 2007). Jól ismert globális következményei a jeges területek változásai, a szélsőségesebb időjárás, a szaporodó katasztrófák, a világtenger szintváltozása, a csapadékmennyiségekben bekövetkező változások, melyek a földfelszín különböző részein eltérő mértékben éreztetik hatásukat (Kertész 2001, Harnos et al. 2008, Rakonczai 2008a). Bizonyos területeken jelentős aszályok jelentkeznek, melyek a felelőtlen emberi tevékenységekkel kiegészülve olyan gyors változásokhoz vezethetnek, mint például a Csád és az Aral tavak kiszáradása. Máshol pedig jelentős károkat okozó hurrikánok, tornádók vagy a jelentős csapadékmennyiség hatására kialakuló árvizek a legfenyegetőbb tényezők.

Magyarország éghajlata kontinentális, jelentős mediterrán és atlantikus hatásokkal. $\mathrm{Az}$ arid, szemiarid és szubhumid térségek definíciója a FAO/UNESCO bioklimatikus indexén alapul, amely a csapadék és a potenciális evapotranspiráció arányát (P/ETP) jelenti. Ezen világviszonylatban használt indexértékek alapján az Alföld a szubhumid és szemiarid területek közé sorolható, így Magyarország az UNCCD szerint a sivatagosodás által érintett országként szerepel (,affected country”) (UNCCD 2006). Mivel a fokozódó szárazság komoly veszélyt jelenthet, Magyarország is aláírója (1999) az ENSZ Sivatagosodás és Aszály Elleni Küzdelemről szóló egyezményének.

Napjainkban az alföldi tájak közül különösen a Duna-Tisza köze szembesül a legjelentősebb vízháztartási problémával a klímaváltozás és az elmúlt évszázadok emberi tevékenysége miatt (Pálfai 1994a, Kuti et al. 2002, Rakonczai - Bódis 2002). Vízhiányának kritikus mértéke, és az ebből fakadó jelentős tájdegradáció mára már sem nemzetközi, sem hazai viszonylatban nem vitatott. A legérintettebb területeken ez nemcsak a természeti területek állapot-romlásában tükröződik (Iványosi 1994, Rakonczai 2006, Barna 2010), hanem a probléma már társadalmi, gazdasági kérdés is (Csatári 2004). A legjelentősebb változások a hátság legmagasabb részein tapasztalhatóak, többek között ez motiválta a mintaterület kiválasztását. A kutatómunka az egyik leginkább érintett régióban (a Duna-Tisza köze délnyugati részén) fekvő Illancs kistáj tájváltozásait vizsgálja a fentebb említett probléma természetes és 
antropogén hatótényezőinek tükrében az elmúlt kétszáz évre visszatekintve. Időben és térben is elemzi a térség vízháztartási problémájának kialakulását, és a hatótényezők szerepét.

A vizsgált kistáj korábban kevéssé volt kutatott, a 21. század elején került részletesebb ökológiai, tájökológiai, növényföldrajzi vizsgálatok alá (Bíró 2006, Csecserits et al. 2010, Horváth 2004, Pándi 2006). A kutatás során már a kistáj lehatárolásánál disszonanciák mutatkoztak a szakirodalomban, amelyek miatt az eredetileg tervezett kutatási tematikát is bővíteni kellett. Az értekezés a környezettudomány széles spektrumát (hidrológia, botanika, tájökológia, talajtan, földtan és földrajz tudományát) felhasználva, a társadalmi vonatkozásokat figyelembe véve kíván komplex elemzést nyújtani.

Azon kérdésekre keresi a választ, hogy:

(1) Milyen tájhasználati változások zajlottak le a területen, ennek milyen okai és következményei vannak? A tájváltozásokból milyen tájtörténeti időszakokra lehet következtetni?

(2) Milyen mértékü az ember környezet-átalakító tevékenysége az Illancson? Milyen mértékben maradt fenn a természetes vegetáció e Duna-Tisza közi kistájban?

(3) Milyen átalakuláson mentek át Illancs vizes élőhelyei az elmúlt 40 év gyors hidrológiai változásainak következményeként? Mennyiben azonosíthatóak a vizes élőhelyek? Megfigyelhető-e a talajok átalakulása?

(4) Mi jellemzi ma az Illancs száraz élőhelyeit? Milyen veszélyeztető tényezőkkel áll szemben (természetes és/vagy emberi hatások)?

(5) Milyen kapcsolatban állnak az erdők - mint az Illancs jelenlegi fö felszínborítási kategóriája - a csapadékkal, azaz mennyire lehetnek érzékenyek a szárazodás fokozódására? Bizonyíthatja-e ez a vizsgált kistáj klímaérzékenységét?

(6) A táj lakói és a gazdálkodók hogyan érzékelik a változást, vagy egyáltalán érzékelhető változás a környezeti tényezőkben? Tapasztalják-e a változások gazdálkodásra ható negatív következményeit? Miben látják a problémák megoldását? Van-e kézzel fogható gazdasági kára a folyamatnak?

Ezen komplex, a környezettudomány sokszínűségét tükröző kutatás kiemelt jelentőssége az, hogy feltárja a tájban aktuálisan zajló folyamatokat, kitekintést ad az elmúlt évszázad változásaira, így hozzájárul a lehetséges és célszerü természetvédelmi (és környezetvédelmi) kezelések reális céljainak megfogalmazásához (tájmenedzsment és környezetközpontú vízgazdálkodás).

(A doktori értekezés a sokoldalú megközelítés és a különböző módszerek alkalmazása miatt némiképp eltér a klasszikus tagolódástól, viszont minden értékelő fejezetében visszatükröződik a doktori iskola átlal elöírt irodalmi áttekintés-módszerek-eredmények felosztás). 


\section{AZ ELMÚLT ÉVTIZEDEK TÁJVÁLTOZÁS-KUTATÁSA MAGYARORSZÁGON ÉS A SZÁRAZODÁS}

A tájkutatásokban a 21. század elejére egyre nagyobb hangsúlyt kapnak a változásra és a degradációra irányuló vizsgálatok, hiszen a tájváltozások időbeni áttekintése a tájrehabilitációs és tájvédelmi feladatok elvégzéséhez meghatározó jelentőségűek. A gyakorlati megvalósítások többnyire valamilyen közigazgatási egységben gondolkoznak, azonban a környezeti problémák általában valamely természetföldrajzi egységhez kötődnek (tájak, vízgyüjtők stb.). A tájökológiai kutatások általában chorikus szintekre vonatkoznak, azonban ezen elemzéseknek is számos korlátozó tényezője fedezhető fel. Csak a táj fogalmának meghatározása geográfusok egész generációját foglalkoztatta, tudományos iskolák jöttek létre, és az 1900-as évek második felében hosszú időn keresztül szakfolyóiratokban lehetett végigkövetni az ezt övező tudományos vitát (Bulla - Mendöl 1947, Góczán 1961, Bulla 1962, Somogyi 1967, Pécsi - Somogyi 1967, Pécsi 1972, Pécsi et al. 1972, Székely 1973, Marosi 1980). Emellett a mező- és az erdőgazdálkodás, a tájépítészet, a filozófia és a művészet is sajátos tájfogalmat használ (Mezősi - Bata 2010). A tájfogalom tudományos megfogalmazása azért nem egyszerü, mert a táj egyszerre geográfiai, kulturális, történelmi és esztétikai kategória (Csorba 1999). A tájak határvonalainak meghúzása sem minden esetben egyértelmü, hiszen a tájalkotó tényezők - földtani, domborzati, éghajlati, vízrajzi, botanikai és talajtani adottságok - változása általában nem különül el éles határral. A probléma jelentősen függ a méretaránytól is, hiszen például egy milliós léptékü térképen a legfinomabb vonal is több $10 \mathrm{~km}$-es sávot takar (Csorba 2008). A tájhatár pontossága elvileg is korlátozott: habár elfogadjuk, hogy a táj egy integrált, komplex egység, mégis az értékelése a különböző tájalkotó tényezőkön át történik, melyek alapján sok esetben más-más határ húzható (Mezősi - Bata 2010).

A táj - mint összetett, funkcionális egység (1. ábra) - egy tájalkotó tényezőjének változása (változtatása) az egész struktúra valamilyen mértékü változását okozhatja. A táji kapcsolatrendszerek átlátásához szerteágazó ismeretek kellenek, de tájökológiai értelmü indikátorok segítségével lehetőség nyílhat a változó táji folyamatok felderítésére (Kovács et al. 2004, Csorba 2006).

A változás mértékére például a tájalkotó tényezők dinamikájának vizsgálata adhat választ. A dinamika kutatása napjainkban a felgyorsuló degradációs folyamatok kapcsán egyre jelentősebb szerepet kap. A tájdinamikai kutatások legszembetűnőbb és legjobban megragadható összetevője a tájhasználat változása (Frisnyák 1990, Konkolyné Gyúró 
1994, Barczi et al. 1996, Illyés 1997, Beluszky 2001, Szilassi 2006). A távérzékelés lehetőséget nyújt a vegetációs dinamika spektrális indexekkel történő vizsgálatára is (Kennedy et al. 2009), melyekkel a biomassza-aktivitás (Kovács 2006) és akár a meteorológiai paraméterekkel való kapcsolat is értékelhető (Kern et al. 2007). A modern tájkutatás eszközei lehetnek a tájdinamikai modellek is (Duray 2009). Ezek részben analitikusan a tájalkotó tényezők átalakulását vizsgálják, de lehetnek holisztikus jellegủek is, melyek a földhasználattal együtt bekövetkező, gyakran mélyreható változásokat is igyekeznek megragadni (Lóczy 2010).

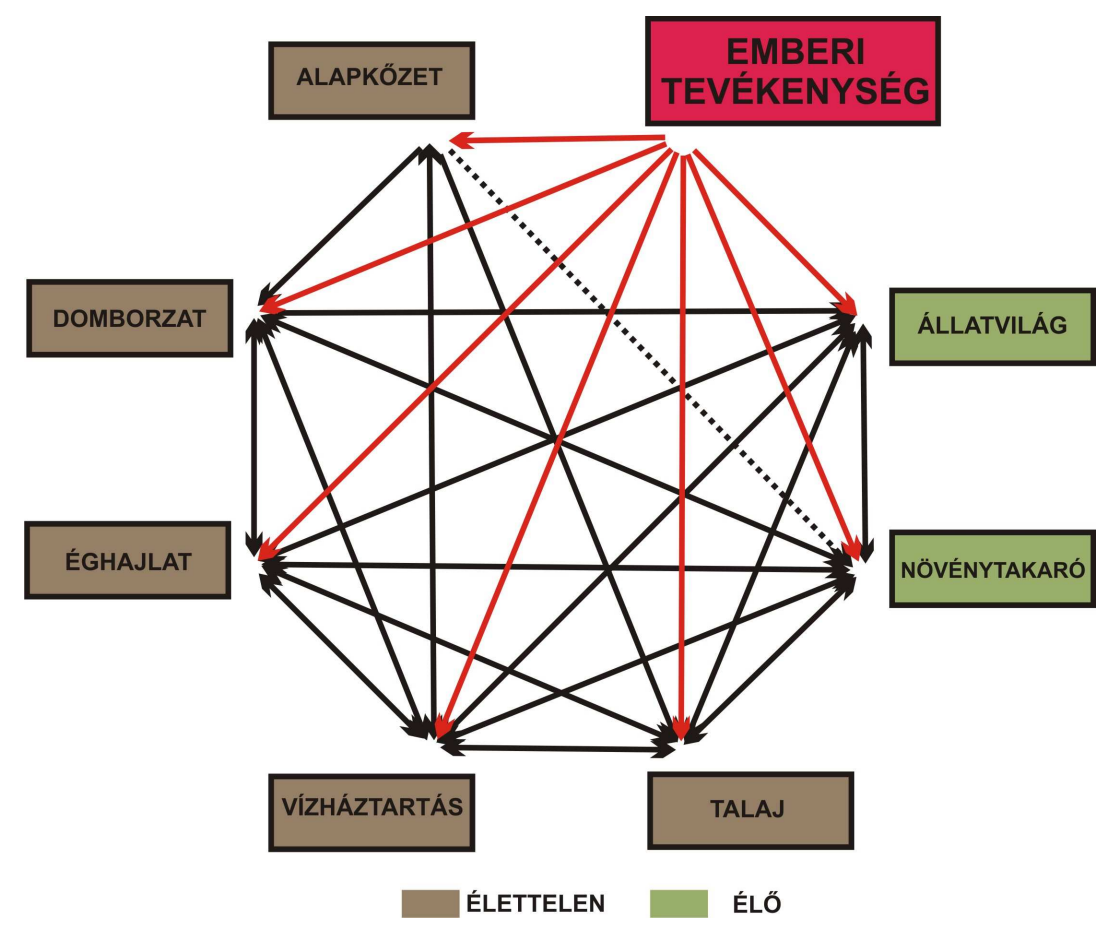

1. ábra. Tájalkotó tényezők, és kölcsönhatásaik (Bauer - Veinitschke 1976 alapján)

A tájmetriai mérőszámok a kvantitatív tájanalízis fontos részei (Mezősi - Fejes 2004), segítik a tájstruktúra és az ökológiai folyamatok megértését. Alapjuk a táj müködésében szerepet játszó foltok, folyosók és az általuk létrehozott mátrix, melyek vizsgálata által például a tájökológiai összekapcsoltságra, a tájökológiai stabilitásra, az ökoton zóna jellegére és méretére, vagy a táj ökológiai folyosókban való gazdagságára nyerhetünk információkat (Csorba et al. 2006). Általában a foltok válnak a vizsgálatok tárgyává, mivel ezek geometriai tulajdonságai (terület, kerület, alak, stb.), valamint relatív térbeli elhelyezkedése (pl. foltok közelsége, konnektivitás) matematikailag egyszerüen számítható (Csorba 2006, Szabó -Csorba 2009, Túri - Szabó 2009, Szilassi 2010).

Az elmúlt évtizedekben a tájkutatásokban egyre nagyobb szerep jut a történeti tájökológiai kutatásoknak (Bíró - Molnár 1998, Molnár 2003a, Deák 2004, Bíró et al. 2007, 
Molnár et al. 2008). E vizsgálatokkal a táj múltbéli viselkedéséről, átalakulásának irányáról és okairól gyüjthetőek adatok, melyek az aktuális folyamatok megismerésén túl tájtervezési célokat is szolgálhatnak. A múlt megfelelő ismerete javítja a predikciók megbízhatóságát is (Molnár - Bíró 2010).

A tájkutatások jelentős része irányul manapság a táj degradációjára (például a szárazodó klíma és a vízhiány következményei, a felszíni vizek minőségi és mennyiségi problémái, vagy a talajtermékenység tekintetében), de a táj változása nem feltétlenül jelenti annak degradációját.

A tájdegradáció okait a táj erőforrásainak kapacitását túllépő antropogén hasznosításban és a tájban magában rejlő ökológiai érzékenységében kell keresni. A hatások minőségének, mennyiségének különbözősége, valamint az érzékenység térben és időben változó természete megnehezíti a környezeti érzékenység megállapítását is. A degradációs jelenségek következményei három csoportba sorolhatóak a káros folyamat által érintett közeg alapján (Bádonyi 2001):

- talaj: termékenység csökkenés, a szerkezet változása, erózió, szikesedés/ sziktelenedés, savanyodás

- vegetáció: a növénytársulások szerkezetének változása, pusztulása

- a felszíni és felszín alatti vizek minőség és mennyiségi problémái

A jelenség ma már nemcsak lokális és regionális léptékben értelmezhető, hanem a globális problémák hatására világméretüvé is vált.

Magyarországi viszonylatban regionális léptékű tájdegradáció leginkább a klímaváltozás és az antropogén tevékenységek együttes hatására kialakuló Duna-Tisza közi talajvízszint-süllyedés nyomán figyelhető meg. A klímaváltozás következményeképpen fellépő, a hosszú távú adatsorokkal bizonyítható csapadékcsökkenés (szárazodás), valamint a trendszerü hőmérsékleti emelkedés hatására a szemi-arid jelleg fokozódik (Kertész et al. 2001, Rakonczai - Kovács 2004), mely a jövőben a terület fokozott érzékenységét tovább növelheti. A Duna-Tisza közén a természeti területek állapotromlását már az 1970-es években észlelték (Buzetzky - Zsuffa 1976), habár ekkor még csak az antropogén beavatkozásokat (vízrendezések) okolták a kialakult helyzetért. Mára egyre szaporodnak azok a kutatások, amelyek kifejezetten a szárazodás (és a vízhiány) hatását vizsgálják, regionális és lokális léptékben egyaránt (Kertész et al. 2001, Hoyk 2005, Rakonczai - Kovács 2005, Varga 2009, Zsákovics et al. 2009). 


\section{VÍZHIÁNY A DUNA-TISZA KÖZÉN}

A Duna-Tisza közi hátság regionális vízgazdálkodási kérdései napjainkban az Alföld környezeti problémái közül a legfontosabbak közé tartoznak. A közel 10.000 km² kiterjedésű hátság problémái lényegében abból fakadnak, hogy a talajvíz szintje - különböző okok miatt - rendkívül mélyre süllyedt (2. ábra). Jelen fejezet a vízhiány kialakulásában szerepet játszó tényezők bemutatását, a vízhiány elemzését, a problémával foglalkozó szakirodalom és a politikai válaszreakciók elemzését tűzte ki célul. Mindezen történeti és tudományos elemzés a kialakult vízhiány-probléma ok-okozati összefüggésének feltárására koncentrál, hiszen a dolgozatban vizsgált kistáj tájváltozásai mögött többek között a DunaTisza köze régiós léptékü problémái állnak.
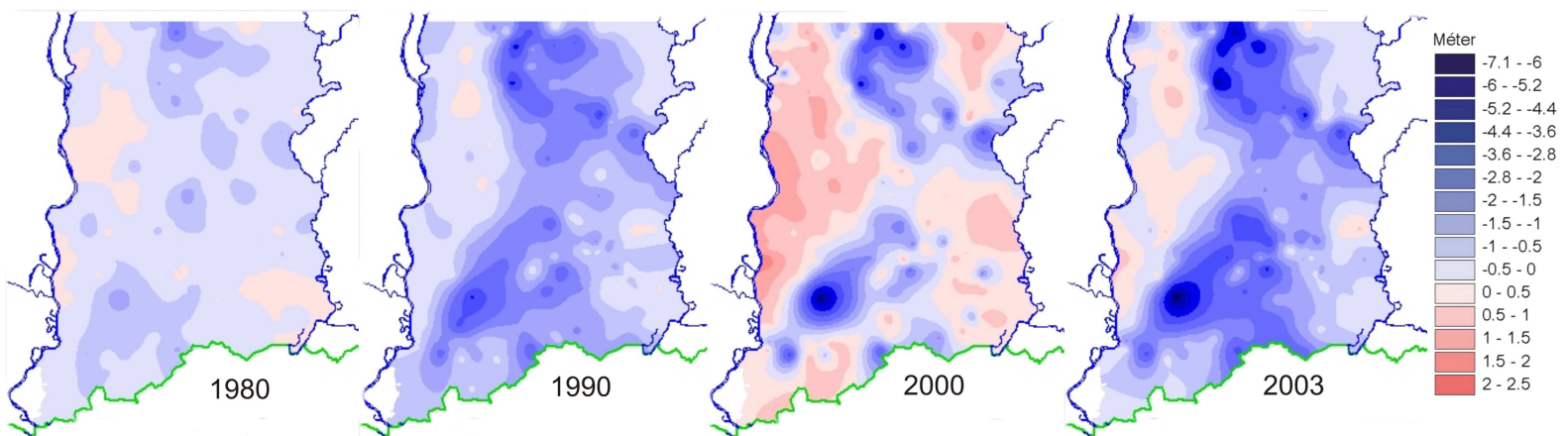

2. ábra. A talajvízszint-változás mértéke 1980, 1990, 2000 és 2003 márciusában a Duna-Tisza közén (az 1971-1975. évi átlaghoz viszonyítva) (Kovács A. 2005)

\subsection{A vízhiány értékelése}

Magyarországon az 1930-as évektől kezdték el kiépíteni a talajvíz helyzetét részletesen mérő kutak hálózatát. Jelenleg a Duna-Tisza köze területén mintegy 300 törzshálózati talajvízszint-észlelő kút adatait gyüjtik a területileg illetékes vízügyi igazgatóságok. A talajvíz-állapotok részletes térképezése elsőként az Alföldön 1950-1954 között zajlott le (Rónai 1961). Később, amikor a talajvízszint süllyedő tendenciájára fény derült, a talajvízkutak adatainak értékelését számos kutató elvégezte (Pálfai 1994a, Liebe 2000, Rakonczai - Bódis 2001, 2002, Kuti et al. 2002, Rakonczai 2006, VITUKI 2005, Szalai Nagy 2006, Völgyesi 2006). A vízhiány becslését három elemzés kísérelte meg, azonban a lehatárolt terület és a különböző vizsgált időintervallum következtében a megállapított mennyiségek különböznek. Rakonczai és Bódis (2002) kutatásaiban az 1970-1974 közötti időszak átlagához képest vizsgálta a talajvízszint süllyedését és 1995 márciusáig 4,87 milliárd $\mathrm{m}^{3}$ vízhiányt állapított meg. Az 1990-es évek közepének csapadékosabb évei következtében a vízhiány mérséklődni látszott, de az 1970-es évek közepétől 2003-ig terjedő periódusra vonatkozóan Rakonczai (2006) már újra közel 5 milliárd m³ vízhiányt becsül. A 
VITUKI Környezetvédelmi és Vízgazdálkodási Kht. által 2005-ben készített, „A DunaTisza köze hidrológiai - környezeti állapotértékelése” c. zárójelentés az 1956-60-as évek átlagától vizsgálta a rendkívül aszályos 2003. évhez viszonyított átlagos talajvízszintek eltérését, ahol a hiányzó talajvízmennyiséget a hátság északi részén 1950 millió m³ , a hátság déli részére 2050 millió $\mathrm{m}^{3}$-ben állapította meg (Gyirán 2009).

Regionális léptékben először az 1980-as években észlelték először a Duna-Tisza közén a talajvízcsökkenés folyamatát, de az ilyen jellegü változás nem csak ezt a tájat érintette (Rakonczai - Kovács 2005, Rakonczai 2008a). A talajvízszint-csökkenés hatására fokozatos aridifikáció indult el: lápi és szikes élőhelyek száradtak ki, a tavak kiterjedése csökkent és az idő elteltével ez a folyamat csak egyre inkább fokozódni látszik. A talajvíz jelentős csökkenése változásokat indukál a talajban és a vegetációban is (Kertész et al. 2001, Rakonczai et al. 2008, Margóczi et al. 2008), mely továbbgyürüzve hatással van az élővilág többi részére is.

A jelenség fő okairól eleinte csak vizsgálat nélküli föltételezések hangzottak el. A természetvédők a csatornák látványos vízelvezető hatására már az 1980-as években felhívták a figyelmet, és a talajvízszint-csökkenés fő okát a csatornák talajvíz-elszívó hatásában vélték felfedezni (Iványosi Szabó 1994). A rétegvíz-kitermelés hatása a Magyar Hidrológiai Társaság pécsi vándorgyülésén kerül elő először (Pálfai 1994b).

A talajvízszint-süllyedés okainak tisztázására a VITUKI-ban végeztek elöször vizsgálatokat (Major - Neppel 1988). Mérési adatokon nyugvó vízháztartási számításokkal és bizonyos területi analógiák felismerésével kimutatták, hogy a talajvízszint-süllyedést az 1971-től kialakuló jelentős csapadékhiány, az erdőterületek növekedése és a rétegvízkitermelés fokozódása együttesen idézték elő. A rétegvíz-kitermelés és a talajvízszintsüllyedés kapcsolatát a VITUKI szimulációs modellvizsgálatának eredményei bizonyították (VITUKI 1989), majd később Berényi és Erdélyi (1990) megállapítja, hogy a rétegvíz túlzott kitermelése a fő oka a talajvíz-süllyedésnek, melynek hatását csak fokozza a száraz időjárás. A rétegvíz-kitermelés mellett a talajvíz-kivétel hatása is a folyamatban jelentősebb befolyásoló tényezőnek bizonyult (Csordás - Csatári 1990, VITUKI 1991). Az erdőterületek befolyásoló hatásával kapcsolatban az 1990-es évek elején pro és kontra érvek hangzanak el az erdészet, és a vízügy oldaláról (Szofridt 1990, 1991, Major - Neppel 1990). A szén-hidrogén bányászat is a talajvízszint-süllyedést befolyásoló lehetséges okok közé sorolható, mely Kovács (1984) feltételezése szerint megzavarhatja az egységes felszín alatti vízrendszer müködését, így nem zárható ki, hogy a Hátság déli részén tapasztal- 
ható talaj-, és rétegvíz-süllyedéshez valamelyest hozzájárulhatott ${ }^{1}$ (lásd KiskunhalasSzank környéki bányászati tevékenységek) (Pálfai 1994b). A kutatások folytatását és kiszélesítését más érintett tudományok képviselőinek bevonásával tüzte ki célul egy további tanulmány (Pálfai 1990), amely a vizsgálati eredmények összegzéseképpen az addig meghatározott befolyásoló tényezők között arányokat határoz meg. Az időjárás (csapadék és párolgás) aránya a legjelentősebb (50\%), majd a hatótényezők sorrendjét az alábbiakra becsüli: a rétegvíz-kitermelés $25 \%$, a földhasználatban bekövetkezett változások (erdősültség stb.) 10\%, a vízrendezés 7\%, a talajvíz-kitermelés $6 \%$ és egyéb tényezők (pl. szénhidrogén-termelés) $2 \%$. E kutatások szerint tehát a természetes és a mesterséges tényezők körülbelül fele-fele arányban felelősek a probléma kialakulásáért, mely arányokon Pálfai (1994b) későbbi összegző tanulmánya sem változtatott.

Harmati (1994) és Iványosi Szabó (1994) már az 1990-es évek elején adatokkal támasztják alá a nagyfokú csapadékhiányt, és döntő okként említik a süllyedés előidézésében. Habár ekkor a csapadék mennyiségének csökkenése csak fele arányban tünt felelősnek a folyamatban, később további kutatók világítottak rá, hogy a csapadékhiány ennél még inkább befolyásoló tényező lehet, és hogy a legjelentősebb vízhiánnyal rendelkező területek erős kapcsolatban állnak a domborzattal (Rakonczai - Bódis 2002). A DunaTisza köze felszín alatti vízforgalma szempontjából fontos, hogy a táj a két nagy folyó között hátszerüen emelkedik ki, így a talajvíz utánpótlódásában csak a csapadéknak van meghatározó szerepe. A beszivárgás következtében a terepet többé-kevésbé követő talajvíz-domb alakul ki, mely a legmagasabb részeken van a legmélyebbre a felszíntől. A gravitációs megcsapolódás eredményeképpen (a mélység és a völgyek felé) a magasabb térszínen a talajvízszint sokkal érzékenyebbé válik a csapadékosság változásaira, mint a mélyedésekben, hiszen ott a csapadékon kívül oldalirányból is érkezik utánpótlás (3. ábra).

Völgyesi (2006) kutatásai alapján szintén hangsúlyozza, hogy a legerősebb faktor a talajvízszint-süllyedés tekintetében az időjárás, mely a magas térszínű területeken 80\%-os súlyú. 13\%-ban befolyásoló az erdő a magas térszínü területeken és 5\% alatti szerepe van a belvízcsatornáknak. A víztermelés hatását a megelőző tíz évre 2\%-nál kisebbre becsüli, és megállapítja, hogy a jelentősebb változások az 1960-as évektől kezdődően játszódtak le, amikor szinte a nulláról indulva 30 év alatt maximálisra nőtt a kitermelés. Szanyi és Kovács (2009) modellszámításokkal világít rá az antropogén és a természetes hatótényezők arányára.

\footnotetext{
${ }^{1}$ A terepbejárások során kiderült, hogy a hátságon jó néhány gazdálkodó a szénhidrogén-kutatásokat okolja a vízhiány kialakulásáért. Többek tapasztalata szerint rövid idővel a szeizmikus robbantások után az ásott kútjukban jelentősen csökkent a vízszint.
} 
Megállapítja, hogy a hátság legmagasabb részein a vízhiány döntően (80\%-ban) természetes okokra, azaz a klímaváltozásnak köszönhető csapadékhiányra vezethető vissza.

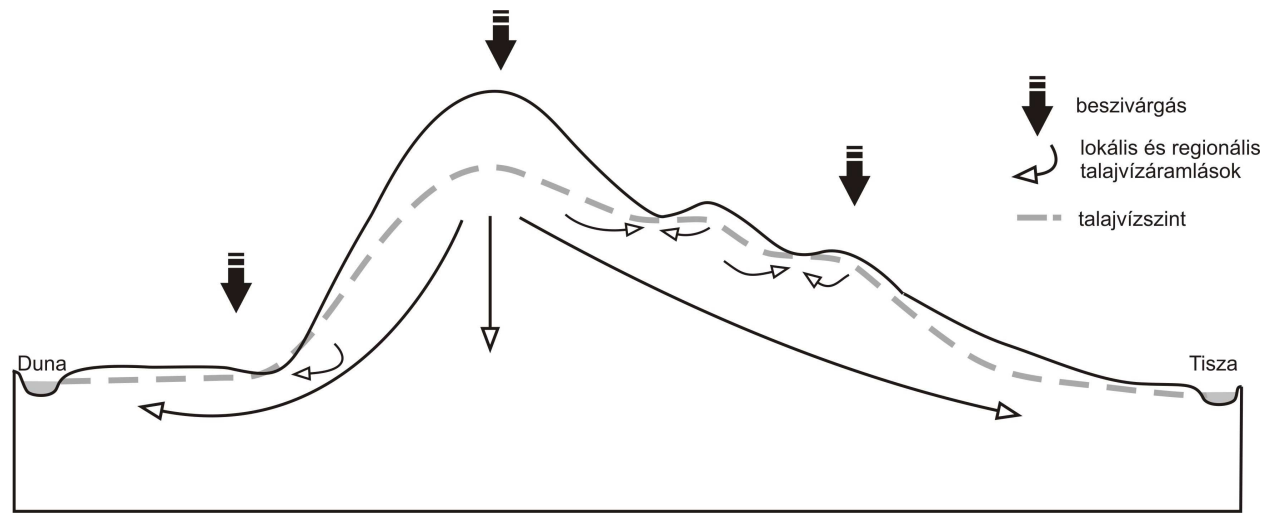

3. ábra. A Duna-Tisza közi Hátság talajvíz-áramlási rendszerének elvi vázlata (Kákonyi 2009 és Völgyesi 2006 alapján)

Az előbbiek alapján az a megállapítás tehető, hogy a térségben egy tartós csapadékhiányra visszavezethető, a geomorfológia által vezérelt talajvíz „kiürülési” folyamat van, mely a legmagasabb térszíneken a leglátványosabb. Ezt támasztja alá a Duna-Tisza közi talajvízkútadatok geostatisztikai értékelése (4. ábra) is. A klaszterek geomorfológiai szempontból jól értelmezhető csoportokat jelölnek ki a felszíni vízutánpótlódás és a vízmozgások szerint, valamint jól tükrözik a felszínközeli földtani képződmények szerepét is (Rakonczai 2008b).

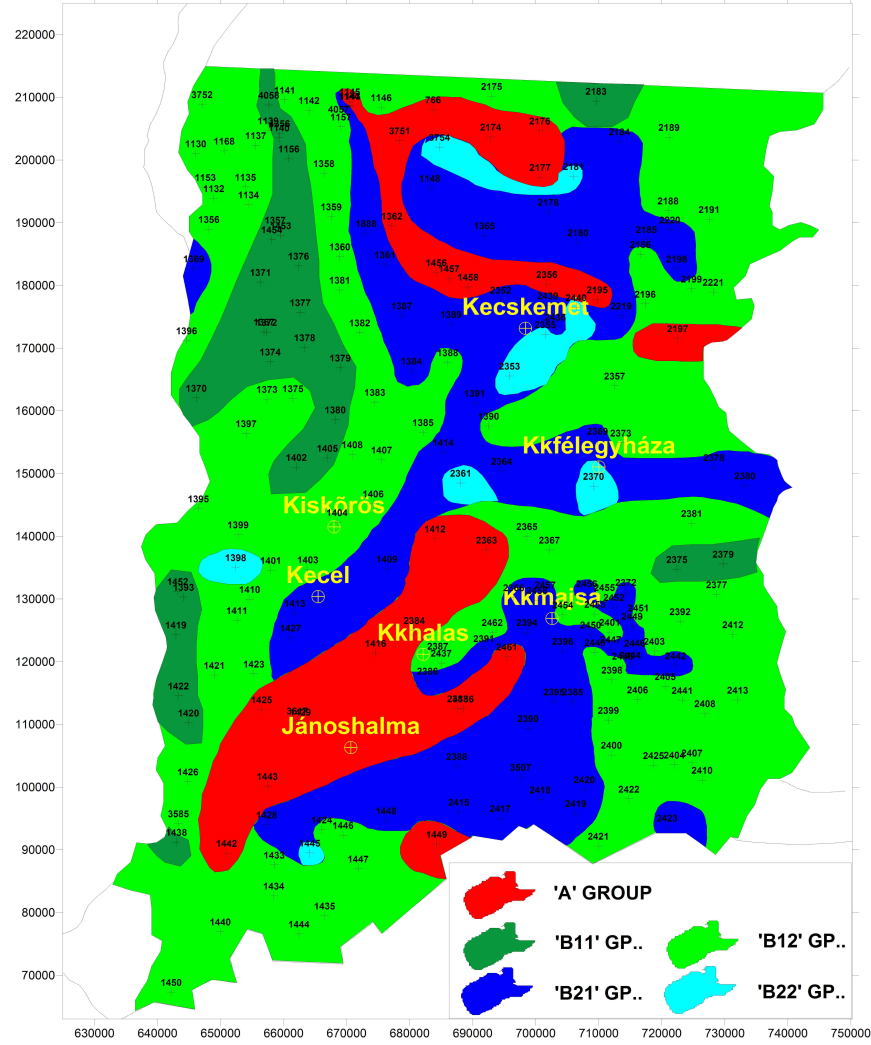

4. ábra. A Duna-Tisza közi talajvízszint-észlelö kutak adatainak klaszteranalízise (Rakonczai 2008b) 
A Duna-Tisza köze problémája a kutatások szerint tehát legnagyobb mértékben az időjárási feltételek változásaihoz köthető. A csapadék éves mennyiségét vizsgálva (5. ábra) valóban negatív trend figyelhető meg az adatsorokban. Évszakos lebontásban a legjelentősebb csökkenés tavasszal mutatkozik, a nyári viszont alig változik. A nyári csapadékok hasznosulását viszont a melegebb hőmérséklet lerontja (Rakonczai 2008a).

Az elmúlt száz év alatt szintén jelentős változást mutat az éves átlaghőmérsékletek alakulása is (6. ábra). A változás hazánkban is a globális változásokhoz hasonló mértékü, az évszakok tekintetében a legjelentősebb melegedés nyáron figyelhető meg (7. ábra).

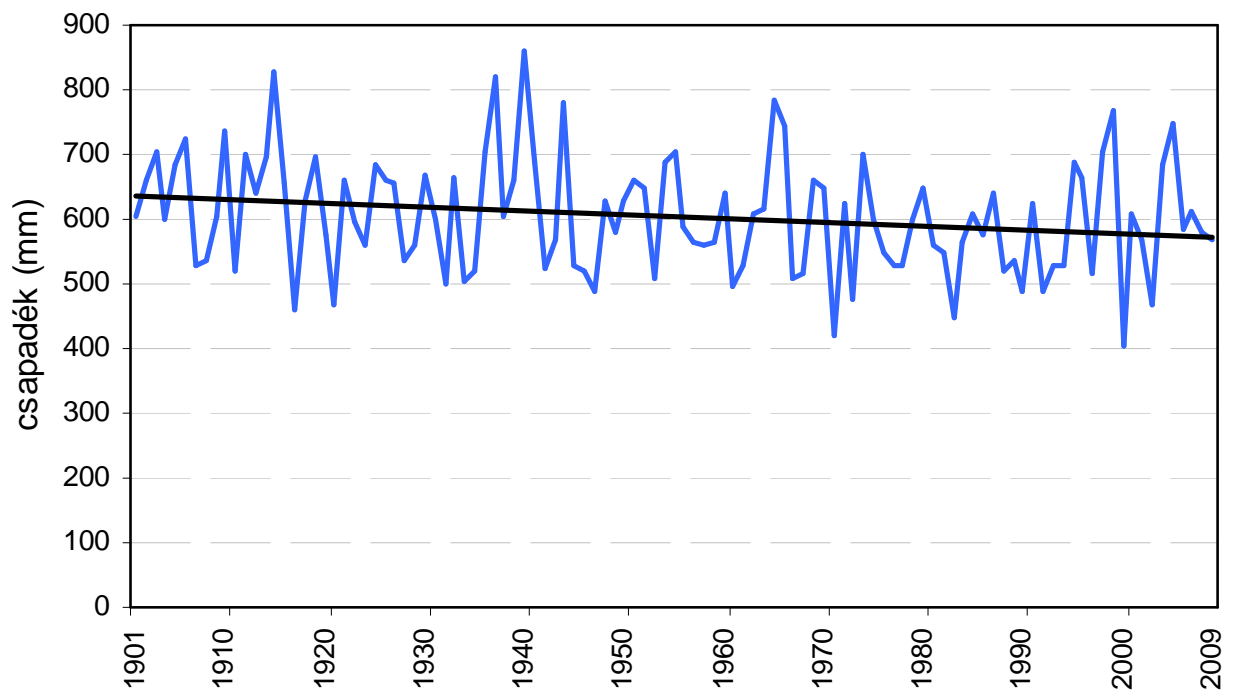

5. ábra. A csapadék éves mennyiségének változása hazánkban (az OMSZ adatai alapján)

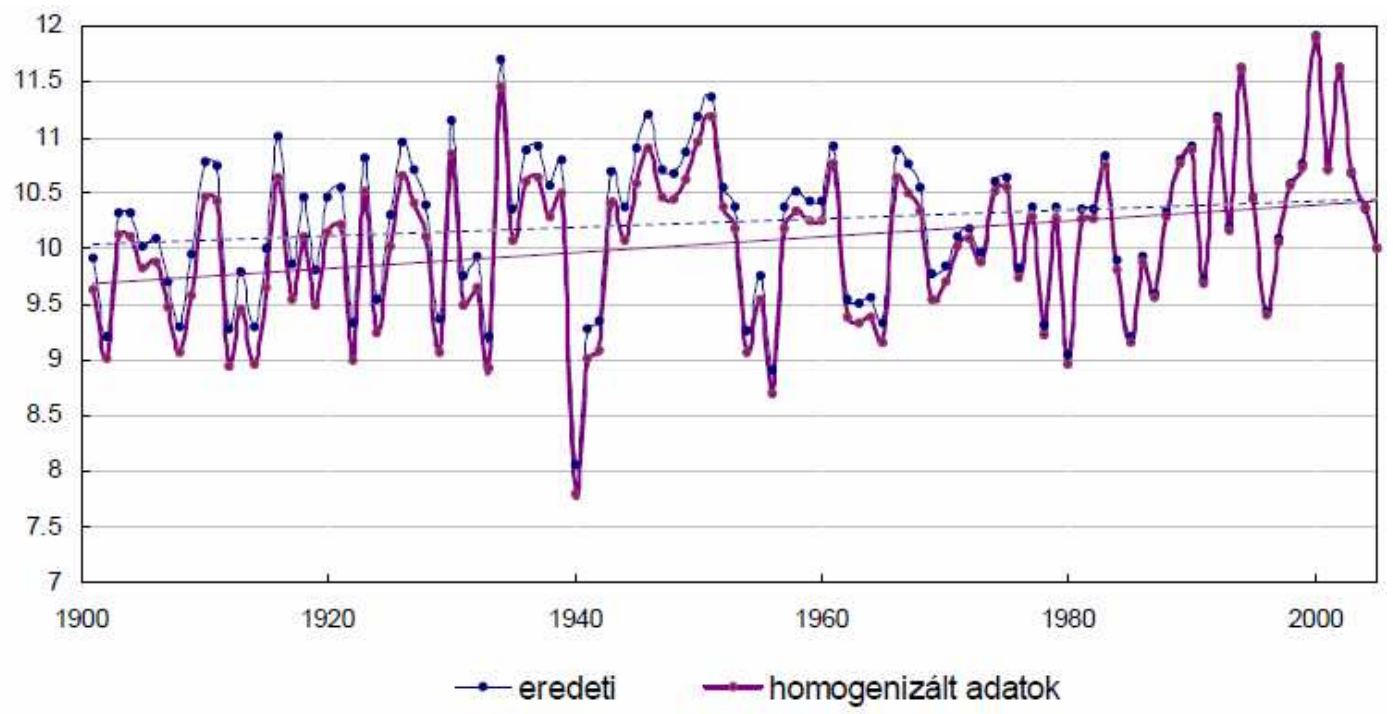

6. ábra. 15 magyarországi állomás adataiból számított eredeti és homogenizált évi középhömérsékleti átlagsor (1901-2005), az illesztett lineáris trendvonalakkal (forrás: OMSZ) 


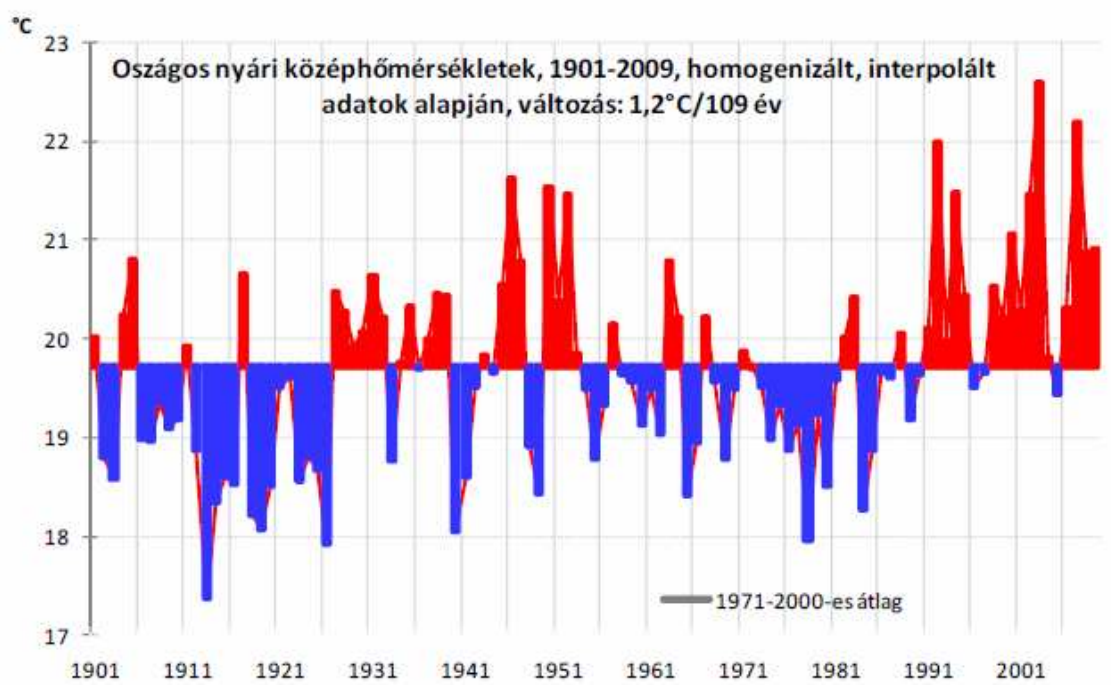

7. ábra. A nyári középhőmérséklet változása 1901-2009 (forrás: OMSZ)

Az éghajlat e két fő elemének vizsgálatából az látszik, hogy az éghajlat kissé melegedni és szárazodni látszik (Mika et al. 1995, Szász 1997, Szalai - Szentimrey 2001). E változások hatásai megjelennek közvetlen környezetünkben is. A különböző tájak adottságai jelentősen befolyásolják azt, hogy az ember a változásokat milyen mértékben érzékeli. A regionális klímamodellek a Kárpát-medence területére további melegedést jósolnak, a legnagyobb mértékű melegedés várhatóan a nyári időszakban következik be. Télen több csapadékra számíthatunk, és a modellbecslések alapján az időjárás is szélsőségesebbé válik (Bartholy et al. 2005, Bartholy - Pongrácz 2008).

\subsection{A Duna-Tisza közi vízhiány probléma kronologikus áttekintése}

A 20. század első harmadában lezajlott vízrendezések jelentősen befolyásolták a DunaTisza köze hidrogeográfiai képét. A 1975-ben alapított Kiskunsági Nemzeti Park már módosult hidrológiai feltételek között tette meg első lépéseit: érintetlen és félkultúr tájrészletek kaptak magas védelmet, melyeket szélsőséges vízháztartás és sajátos élővilág jellemez. Az antropogén beavatkozások hatására egyre inkább csökkenő tendenciát mutatott a vízfelületek száma és kiterjedése is, így már 1976-ban felmerült a vizes területek állapot-megőrzésének fontossága, javítása a legnagyobb összefüggő vizenyős területek, a Kisrét-Zabszék-KelemenszékFehérszék tórendszer és a Kolon-tó esetén (Buzetzky - Zsuffa 1976). Az 1980-as évek elején kezdődő jelentős változásokra először a természetvédelem figyelt fel. Jelentéktelenné kezdett válni a Duna-Tisza közi madármozgás a vonulások idején, felbomlottak a sziki, szikes tavi, réti fészkelő közösségek (Iványosi Szabó 1994). Mint kiderült, a vizes élőhelyek területének csökkenésre a vizes élőhelyen költő madárfajok reagáltak leggyorsabban. 
A VITUKI Talajvízhidrológiai Osztályán 1960-as évektől kezdődően havonta „Talajvízállás Tájékoztató Térképek” készültek (Major - Neppel 1988). Ezeken a térképeken már az 1970-es évek elején a Duna-Tisza közén nagy kiterjedésü talajvízcsökkenést kísérhettek figyelemmel, mely eltért az addigi megfigyelésektől. 1980-ban, egy kecskeméti kerekasztal-beszélgetésen a természetvédők oldaláról már vizsgálatok nélküli feltételezések is elhangzottak a süllyedés okait illetően, majd 1981-ben, a Magyar Hidrológiai Társaság pécsi vándorgyülésén is előkerült a Duna-Tisza közi talajvizek süllyedő irányzata (Pálfai 1994b). Rónai András az 1980-as évek elejei vízszintváltozások tanulmányozása során már azt a kijelentést tette, hogy „a víznívók az Alföldön általában süllyednek; a süllyedés 1976-77. év óta különösen erős” (Rónai 1983).

Major és Neppel (1988) elsőként emelték ki a probléma jelentőségét az egész Duna-Tisza közére vonatkoztatva. A „Talajvízállás Tájékoztató Térképek” alapján nagy kiterjedésű, szinte folyamatos talajvízszint-csökkenést állapítottak meg, és részletesen elemezték azt a 3 tényezőt, amelyek a jelentős változásban a kutatások szerint szerepet játszanak. Az a tény, hogy a cikk az erdők vízfelhasználását tulajdonította a Duna-Tisza közi talajvízszint-süllyedés egyik jelentős okozójának, (ahogy már korábban elmítettük) vitákat indított el a kutatók között: az erdészet és a vízügy érvei kerültek egymással szembe a Vízügyi Közlemények oldalain (Szofridt 1990, 1991, Major - Neppel 1990). 1989-ben a VITUKI-ban kidolgozásra került a Duna-Tisza köze talajvíz viszonyainak numerikus számítógépi szimulációs modellje, mely közelebb vitte a kutatókat a talajvízsüllyedésrétegvíz-kitermelés viszonyának megismeréséhez (VITUKI 1989, Liebe 1994).

A KVM Vízgazdálkodási Főosztályának megbízására a MTESZ Csongrád Megyei Szervezete által felkért munkacsoport 1990 tavaszán Elötanulmány a Duna-Tisza közi hátság vízgazdálkodási problémáinak rendezésére címmel végzett kutatásokat, mely Kiskunmajsa-Jánoshalma közötti térségben vizsgálta a talajvízsüllyedés okait, és meghatározta a befolyásoló tényezők arányait is. A megelőző kutatások alapján 1990 őszén a KVM Vízellátási Főosztálya a Magyar Hidrológiai Társaságnál megrendelte a Duna-Tisza közi vízrendezések hatásának elemzését, a VITUKI pedig az ehhez szükséges alapozó szakvélemények elkészítését (Alapozó szakvélemények a Duna-Tisza közi vízrendezések hatásvizsgálatához). A munkacsoportban már egyetemi oktatók, a Kiskunsági Nemzeti Park Igazgatóságának illetve a Vízügyi Igazgatóságok szakemberei is részt vettek (Pálfai 1990, Pálfai 1992, Pálfai 1994a).Berényi és Erdélyi (1990) megállapították, hogy a vezetékes vízellátás kiépítése óta a rétegvizek szintsüllyedése katasztrofális lett, mértéke pedig regionális. A Hátság lefolyás-viszonyainak megismeréséhez - a Duna-Tisza közi adathiány miatt - a 
Fehértó-Majsai főcsatornán történt lefolyás-vizsgálat meglévő adatok alapján (Major et al. 1991). E csatornák nyomvonalai azonban a Major és Neppel által 1988-ban meghatározott jelentősebb talajvízsüllyedéssel érintett területek zónáját nem érintik, ezért ezen mérések aligha vonatkoztathatóak a Hátság területére.

Kutatás-fejlesztési szerződés jött létre 1991-ben a Közlekedési, Hírközlési és Vízügyi Minisztérium Vízgazdálkodási Főosztálya és az Alsó-Tisza vidéki Vízügyi Igazgatóság között, melynek eredményeképpen 1992-ben elkészült A Duna-Tisza közi hátság távlati vízellátási koncepciója, a területileg érintett vízügyi igazgatóságok, valamint a Budapesti Mủszaki Egyetem Vízgazdákodási Tanszék együttmüködésével. A koncepcióban szereplő legfontosabb teendőket az Országos Vízügyi Főigazgatóság önálló kiadványban tette közzé (Pálfai 1993). Szilágyi és Vörösmarty (1993) később az 1961-1987 közötti talajvízsüllyedéseket osztott paraméterü vízmérleg-talajvíz modell segítségével az 1960-as évi állapotokhoz viszonyították, és szintén elemezték a vízhiány kialakulásában szerepet játszó tényezők szerepét.

Kiskőrösön 1993-ban összefogó konferenciát rendeztek a témáról, ahol megállapították, hogy súlyos ökológiai, társadalmi és gazdasági problémáról van szó, a probléma azonnali beavatkozást igényel és ehhez állami beavatkozások is szükségesek. Még 19931994 folyamán megszületett a vízellátási koncepció gazdasági elemzése (TREBAG), illetve a vízellátási javaslatok környezet-gazdákodási szempontú összehasonlítása (ÖKO Rt.), valamint a VITUKI 1993-as tanulmánya alapján az érintett főhatóságok szabályozták a Duna-Tisza közén talajvízből kielégíthető vízigényeket (Pálfai 1995). Az Alföld programról szóló kormány határozat (2042/1994. (V.9.) Korm. Hat.) szintén kiemelten foglalkozott a Duna-Tisza köze vízgazdálkodási problémáival. 1994-ben két tanulmány készült el a Környezetvédelmi és Területfejlesztési Minisztérium és a Bács-Kiskun megyei Önkormányzat megbízásából a homokhátsági talajvízszint-süllyedés terület és településfejlesztési kölcsönhatásairól (VÁTI 1994a, 1994b).

A Nagyalföld Alapítvány 1994-ben megjelent 3. kötete tette széles körben publikussá a Duna-Tisza köze problémáját és az ezzel kapcsolatos vizsgálatok eredményeit (Pálfai 1994a). Török (1994) egy 1993-as hágai konferencián Magyarország hidrológiai problémáival összefüggésben külön kiemeli a Duna-Tisza közét.

1995-ben születik egy ismételt kormányhatározat (2087/1995. (IV.3.) Korm. hat.) a Duna-Tisza közi hátság kritikus vízháztartási helyzetéről, de még mindig csak tervekről, vizsgálatokról, valamint a megvalósítás feltételeiről. Ugyanebben az időben Pálfai (1995) a Vízügyi közlemények oldalain megjelentet egy tanulmányt, mely elsőként foglalja össze a 
Duna-Tisza köze problémájának történetét, és a felvázolja a lehetséges megoldásokat is. A gazdaságossági kérdések tisztázása érdekében a Közlekedési, Hírközlési és Vízügyi Minisztérium 1995-ben pályázatot írt ki, melyet a TÉRTERV Mérnökszolgálati Kft. nyert meg, és 1995 végére el is készült A Duna-Tisza közi hátság vízvisszatartás és vízpótlás megoldása müszaki és pénzügyi megvalósithatóságának tanulmánya. A munka nem foglalkozik hidrogeológiai kérdésekkel, csak azt tárgyalja, hogy milyen müszaki megoldásokkal lehetne a vizet a hátsági területekre eljuttatni. E tanulmánnyal egyidőben indult, majd 1996-ban készült el a Kertészeti és Élelmiszeripari Egyetem A Duna-Tisza közi hátság vízhiányos helyzetéhez igazodó beavatkozások környezeti hatáselemzése és hatástanulmánya is (Völgyesi 2002).

Az évekig tartó előkészítő munkák után az első gyakorlati lépésnek a 2286/1996. (X. 25.) Korm. határozat tekinthető, amely az 1997-1998-as időszakra megfogalmazta a DunaTisza köze vízgazdálkodási helyzetének javítását célzó feladatokat. Erre alapozva, a Közlekedési, Hírközlési és Vízügyi Minisztérium elkészítette a cselekvési programot és a határozatból adódó feladatok végrehajtásának Intézkedési tervét (1997-98. évi vízvisszatartással kapcsolatos vízügyi beruházások programjának ütemezése) (Rónay 1998). Párhuzamosan a beruházások kezdeti megvalósulásával, 1997-ben készült el A Duna-Tisza csatorna tervezett változatainak vízügyi szempontú értékelése c. munka, melyet a VÁTI Rt. Területfejlesztési Iroda megbízásából a VÍZPART Kft. készített el (Pálfai 1997). A tanulmány részletesen ismerteti a Duna-Tisza csatorna megépítésének több mint 150 évre visszamenő történetét, 26 tervet és tanulmányt tekint át, részletesen elemezve megépítésének aktuális okait, vizsgálja a megvalósítás céljait.

Az 1990-es évek közepén a magyar természet- és környezetvédelem jogi szabályozása terén történt lépések következményeként (1995. évi LIII. törvény, 1996. évi LIII. törvény) 1997-ben országgyülési határozat születik a Nemzeti Környezetvédelmi Programról (83/1997. (IX. 26.) OGY határozat), melyben a Duna-Tisza közén észlelt vízszintsüllyedés és vízhiány kiemelten szerepel a felszín alatti vizek tekintetében.

Pálfai és munkatársai (1998) később az aszály vízgazdálkodási hatásait vizsgálták Magyarországon, és ezzel kapcsolatosan kiemelték az Alföldet, annak is leginkább a középső részét. Később Pálfai (2000) aszályérzékenységi térképet készített az Alföldre vonatkozóan, melyen belül a Duna-Tisza köze egyes részei erős aszállyal sújtott területekként mutatkoztak.

A Duna-Tisza közi homokhátság vízháztartási helyzetéről és a további szükséges intézkedésekről 1999-ben ismételt kormányhatározat született (2271/1999. (X.22.) Korm. 
hat.), melyhez konkrét cselekvési programot mellékeltek. Az 1999-es kormányhatározat folyományaként ismételten elindult egy kutatómunka, amely részben a talajvízszintsüllyedések okainak megállapítását, és az annak ellensúlyozására, visszafordítására szolgáló lehetőségek keresését tűzte ki célul. Ennek keretében a vízpótlás és vízvisszatartás hatékonyságát kívánták meghatározni (Völgyesi 2002).

A komplex kutatások egy rendkívül fontos lépése volt a 2003-ban induló VAHAVA program, melyben több száz kutató, szakember elemezte a magyarországi klímaváltozás egyes ágazatokra, szakterületekre valószínüsíthető hatását (Láng et al. 2007). A program azért fontos és jelentős a Duna-Tisza köze vízhiányának problémája kapcsán, hiszen könnyen elérhető kutatásai eredményeivel, fórumaival, sajtószerepléseivel tudatosította az emberekben, hogy a klímaváltozás és hatása milyen területeken és hogyan hat az emberek életére, és hogy hatása jelentősebb, mint azt évekkel ezelőtt gondolták volna. Döntéshozói szinten - többek között - a legfontosabb ajánlásként a Nemzeti Éghajlatváltozási Stratégia kidolgozására tett javaslat említendő meg, mely később, 2007ben elfogadásra is került. A VAHAVA programmal párhuzamosan zajlottak 2003-ban a Nemzeti Környezetvédelmi Program II. munkálatai (132/2003. (XII.11.) OGY határozat), melyben szintén kiemelt jelentőségủ volt a Duna-Tisza köze problémája.

Orlóci (2003) tanulmányában a Duna-Tisza csatorna megvalósításának indokoltságára, érdemleges szerepének megvitatásának szükségességére hívja fel a figyelmet, időszerünek tart egy komoly vitára való felkészülést. A cikkhez kapcsolódva Pálfai (2003) a Duna-Tisza közi Homokhátság vízháztartási helyzetét és vízgazdálkodási fejlesztési lehetőségeit vázolja fel.

A MTA RKK Alföldi Tudományos Intézete helyzetértékelő és számos kérdést felvető cikkeket közölt Homokhátság 2004 címü kiadványában (Csatári 2004). Csatári keveselte a lényegi lépéseket, amelyek a probléma irányában megvalósultak. Megfogalmazta, hogy a Homokhátság vízháztartási problémái immáron egyszerre ökológiai, ökonómiai, vízügyi, környezet- és természetvédelemi, táj- és mezőgazdálkodási, települési (tanyai) és társadalmi kérdések, problémák. Javasolta, hogy készüljenek a nagy, átfogó tervek alapján végre megyei szintű tervek, valósuljon meg a vízvisszatartás lépésről lépésre, térségi összefogással.

A Duna-Tisza közi hátság területén bekövetkezett kedvezőtlen változások hatásainak mérsékléséröl szóló 2095/2004. (IV. 27.) Kormányhatározat mellékletében többek között „vízpótló rendszer létesítésének lehetöségvizsgálatát” írta elő. 
2005 januárjára ismételten készült egy elemző tanulmány a Bács-Kiskun megyei önkormányzat megbízásából, az Alsó-Tisza vidéki Környezetvédelmi és Vízügyi igazgatóság és a Kiskunsági Nemzeti Park munkatársaival együttmüködve (Pálfai 2005), a DunaTisza közi Homokhátság vízháztartási helyzetéről és vízpótlásának szükségességéről. 2005-ben a VITUKI is készített elemző zárójelentést, A Duna-Tisza köze hidrológiaikörnyezeti állapotértékelése címmel (VITUKI 2005). A Duna-Tisza közi Homokhátság térségét sújtó problémákra reagálva a Kormány 1067/2005. (VI. 30.) sz. határozatával központi költségvetési támogatást biztosított az Új Magyarország Fejlesztési Tervben nevesített Duna-Tisza közi Homokhátság fenntartható fejlesztése komplex térségfejlesztési nagyprojekt előkészítésére. Ugyanebben az évben a Magyar Regionális és Területfejlesztési Hivatal Kiemelt Térségi Programok Főosztálya a Duna-Tisza közi Homokhátság vízpótlásáról szóló országgyülési és kormányhatározatok nyomán átfogó tanyakutatással bízta meg az MTA RKK Alföldi Tudományos Intézetét, mely többek között feldolgozza a tanyás térségek környezeti állapotát, és részletesen elemzi a Hátság vízgazdálkodási helyzetét és problémáit, valamint becsléseket tesz a Duna-Tisza közi vízhiányra (Kovács A. D. 2005).

Kovács F. (2005) biomassza-kutatásai bebizonyították, hogy a Duna-Tisza köze területének 1/4-én a biomassza-mennyiség alapvetően csökkenő tendenciájú, a legérzékenyebb területek a táj középső és DK-i részén határolhatóak le. A szárazodás hatásaival több kutatás is foglalkozott (Kovács - Rakonczai 2005, Hoyk 2005), melyek a talajvízszint süllyedésének területi viszonyait, illetve a vegetáció, a talaj és a táj rövid távú változását elemzik különböző mintaterületek alapján.

Völgyesi (2006) regionális modellt mutatott be a Duna-Tisza közére, melyben elemezte a különböző tényezők hatását és annak mértékét, és hangsúlyozta a vízvisszatartás szükségességét. A Bács-Kiskun Megyei Önkormányzat 2006 márciusában - az Országos Területfejlesztés Hivatal támogatásával - országos konferenciát rendezett, a Duna-Tisza Közi homokhátság komplex fejlesztése címmel, melyen miniszterek, államtitkárok, országgyülési képviselők, akadémikusok is részt vettek, a konkrét feladatok összegzése céljából. A számtalan határozat és szakmai ülés ellenére Rakonczai (2006) kutatásai alapján megállapította, hogy a 2000-es évek elejére, a változások észlelése után mindössze 20-25 évvel, a Duna-Tisza közén már közel 5 milliárd m³ víz hiányzik (a 2003-as aszályos évben), ami közelíti Magyarország teljes éves vízfelhasználását.

A Duna-Tisza közi Homokhátság fenntartható fejlesztése nagyprojekthez kapcsolódó 1067/2005. (VI. 30.) sz. határozat folyományaként 2007 júniusára elkészült egy elözetes megvalósíthatósági tanulmány, majd 2007 októberében a KVVM életre hívott egy 
tárcaközi munkacsoportot, amelynek fö feladata a Duna-Tisza közi Homokhátság komplex program első ütemét képező stratégiai célok és beavatkozási elemek meghatározása volt.

A VAHAVA program és folytatásainak kutatási eredményeire alapozva 2007-ben megszületett a Nemzeti Éghajlatváltozási Stratégia (NÉS 2007) a 2008-2025-ös időszakra vonatkozóan, melyben a Duna-Tisza vízhiánya kiemelt szerepet kapott. Ugyanebben az évben a Magyar Hidrológiai Társaság XXV. vándorgyülésén a VITUKI munkatársai már a Víz Keretirányelv tükrében foglalkoztak a Duna-Tisza közi hátság vízproblémáival (Konecsny 2007, Szalai et. al. 2007). Vitaanyag is olvasható volt az interneten Magyarország jelentős vízgazdálkodási kérdéseiről, majd a kidolgozást követően intézkedési lehetőségek fogalmazódtak meg a szakmai anyagokban a Duna-Tisza közén mutatkozó problémák tekintetében (Víz Keretirányelv 2009). 2009-ben a Hidrológiai vándorgyülésen több előadás is elhangzott a Duna-Tisza közi homokhátság vízpótlás lehetőségeiről (Kozák 2009), a fenntartható vízgazdálkodásról és vízpótlás elvi és műszaki megvalósítási lehetőségeiről (Gyirán 2009, Rónai és Keve 2009).

Számos hazai neves kutató mellett politikusok és képviselők részvételével zajlott le 2009 novemberében Kecskeméten az Aszály és Szárazodás konferencia, melynek eredményeképpen született egy országgyülésnek megküldendő állásfoglalás a hazai helyzetről és konkrét megvalósítandó lépésekről (Aszály és szárazodás 2009). Még 2009 decemberében külön konferencia keretében tekintették át a Duna-Tisza köze és a Duna-Tisza csatorna problémáját Kecskeméten. Ehhez kapcsolódóan az érintett szakterületek képviselői készítettek átfogó, értékelő tanulmányokat a Duna-Tisza köze mai problémáiról, és a Duna-Tisza csatornáról, illetve a közel két évtizede folyó - többnyire sikertelen és eredményeiket illetően meddő - programok hatástalanságának okairól. A 2009-ben körvonalazódó III. Környezetvédelmi programban a probléma újból kiemelt jelentőséggel szerepel.

2010 elején két párt választási programjába is vette a több száz éve tervezett, de soha meg nem valósult tervet, a Duna-Tisza csatornát. A pártok képviselői eltérően ítélték meg, miért is lenne szükség rá: az egyik hajózna, a másik inkább öntözne.

A fenti kivonatos értékelés azt mutatja, hogy a Duna-Tisza köze vízgazdálkodási problémája tény, és a gondok megoldásának szükségessége nem képezi vita tárgyát. Mint látható, mégis számtalan szakmai értékelés, politikai döntés ellenére lényegi elörelépés alig történt. 


\section{A BÁCSKAI SÍKVIDÉK HOMOKTÁJA, AZ ILLANCS}

A harmadik fejezetben részletesen bemutatott környezeti probléma a Duna-Tisza köze legmagasabb területeit fokozott mértékben érinti. Ilyen területek például a Kiskunsági Homokhát északi része, Kecskemét és Kiskunhalas környéke, valamint a Duna-Tisza köze délnyugati részén fekvő Illancs kistáj is. A kutatásom mintaterületéül az utóbbit választottam, mert egyrészről (a Homokhátság legmagasabb részeként) itt a legnagyobb mértékü a talajvízszint csökkenése, másrészről pedig a kistáj kevéssé volt kutatott.

A kistáj nevét arról kapta, hogy az ide vándorló népek hamar rájöttek, hogy talaja szántóföldi müvelésre nem igazán alkalmas, itt nem igazán lehet megélni, ezért a napjainkra fennmaradt szájhagyomány szerint ,az éj leple alatt visszaszöktek származási helyükre, elillantak" (Nebojszki 2004).

\subsection{Illancs természetföldrajzi adottságai}

A negyedidőszak elején a Duna átlós irányban haladt át a mai Duna-Tisza közén Csongrád-Szeged irányában. Az Alföldre kilépve mellékfolyóival (az Ős-Sárvíz és a nyugatról érkező patakok) együtt terjedelmes hordalékkúpokat hozott létre a süllyedő területeken (8. ábra). A folyók a hordalékkúpok fejlődésének törvényei szerint és tektonikus hatásokra gyakran változtatták a medrüket. A negyedidőszak folyamán az Alföld Ny-i felében két hordalékkúp épült. A kisebbik az Ős-Sárvíz hordalékkúpja, mely a Mezőföld irányából nyomult előre délkeleti irányban a bácskai területekre. Építéséhez a déli részen a Mecsekből érkező patakok is hozzájárultak. Ettől északra és keletre a Duna hatalmas hordalékkúpja terült el (Borsy 1989). A Duna folyását a Kecskemét-Nagykőrös vonaltól ÉNy-ra lévő területek emelkedése, és a Kalocsa-Baja-Zombor területen bekövetkező süllyedés változtatta meg alapvetően: a fokozatosan Ny-ra vándorló Duna elfoglalta a mai É-D-i irányú medrét, így az Ős-Sárvíz hordalékkúp-építő tevékenysége megszünt, hiszen a vízfolyás most már nem folyhatott át a bácskai részekre (Borsy 1989). A Mezőföld déli részével és a szekszárdi dombvidékkel tehát a bácskai felszín a Duna-völgy kialakulása előtt összefüggött (Pécsi 1957, Pécsi 1959, Borsy 1977), a kapcsolat egészen a würm közepéig (az interpleniglaciális időszakig) állhatott fenn. A kapcsolatot igazolja az 1980-ban létesített jánoshalmi fúrás, melynek negyedidőszaki rétegsorában Borsy és munkatársai (1981) több mint 10 futóhomok-réteget tártak fel, valamint Franyó (1988) 116 m-ig 26 lösz, homokos lösz, és löszös homokréteg előfordulását mutatta ki. A mélyebb szintekben előforduló fu- 
tóhomok rétegek azt bizonyítják, hogy az interpleniglaciális időszak elött is többször volt homokmozgás a tájon (Borsy et al. 1981). Az Ös-Sárvíz hordalékkúpján előforduló sok futóhomok, lösz illetve löszös réteg a terület formálódása során az eolikus folyamatok jelentős szerepét jelzik (Borsy 1989).

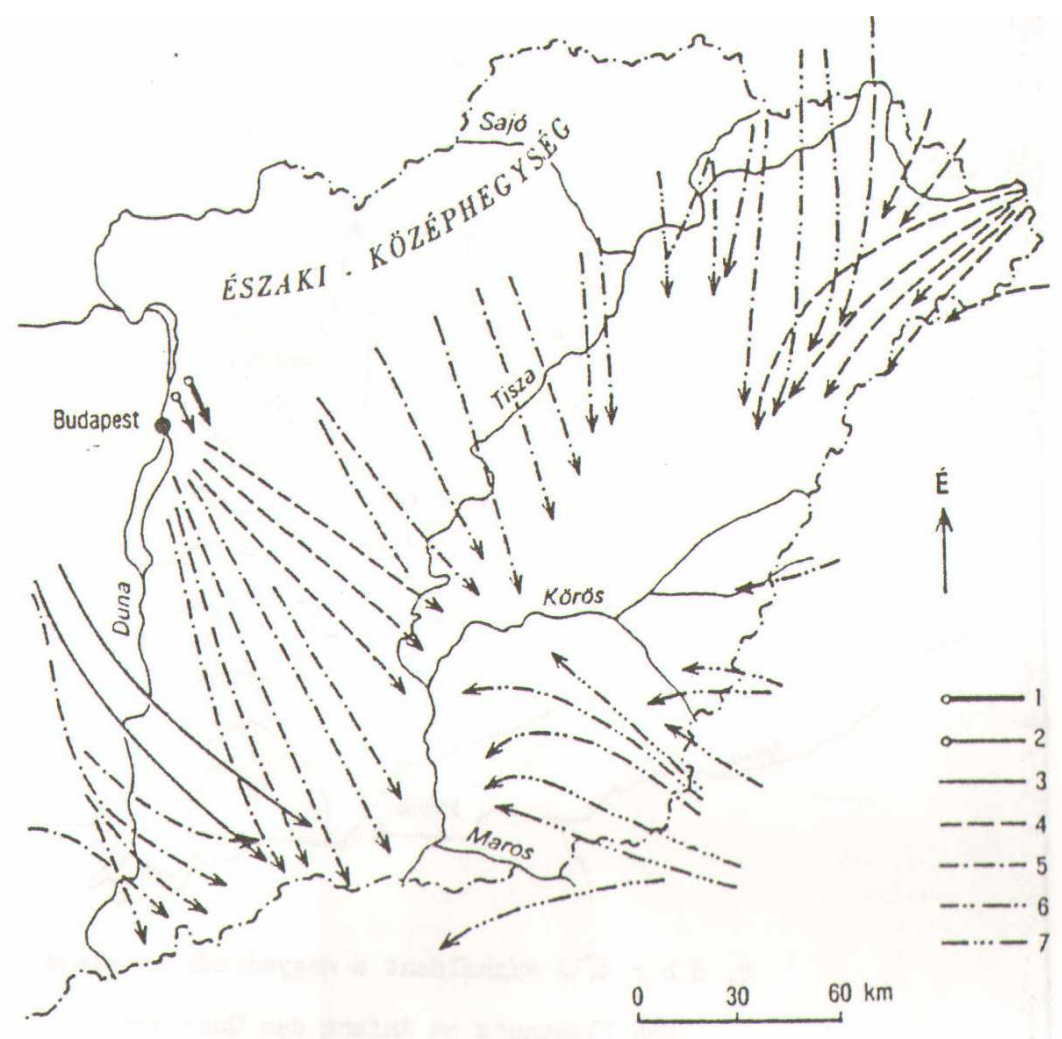

8. ábra. A hordalékkúpok épülésének iránya az Alföldön (Borsy 1989)

1. Az alsó pleisztocén hordalékkúp felszínen levő része; 2. A középsö-pleisztocén hordalékkúp felszínen levő része; 3. A felső-pleisztocénig képződött hordalékkúp; 4. A würm elejéig képződött hordalékkúp;

5. A würm közepéig képződött hordalékkúp; 6. A felső-pleniglaciális elejéig képződött hordalékkúp;

7. A késő-glaciálisig képződött hordalékkúp

Miháltz (1953) kutatásaiban ezzel szemben arra a megállapításra jutott, hogy a Duna már a pleisztocén elején a jelenlegi É-D irányú medrében folyt, és a homokot tisztán a szél halmozta a hátságra. Az általa vizsgált szelvények egységes anyagú, nagy vízszintes kiterjedésü rétegeket mutatnak, mely település folyóvízi lerakódásokban nincs. Azok mindig kisebb kiterjedésű lencsékben ékelődnek ki, egységes anyagú réteg csak nagy kiterjedésü hordalékszállító közegből rakódhat le (levegő).

Molnár (1977) szerint a Duna folyó a Duna-Tisza közi átlós irányú folyását a günz-mindel interglaciálisában hagyta el, és foglalta el a mai É-D irányú helyét, és az eolikus üledéksor ettől kezdve rakódott le. A felsőszentiváni fúrásszelvény vizsgálatában az eolikus és a folyóvízi homok határát 124-128 m-nél állapította meg. Az eolikus üledékek korbeosztását üledékföldtani, pollen és spóra, valamint molluszka fauna alapján 
Miháltz végezte el 77,2 m-ig azon elv alapján, hogy az eljegesedési időszakok löszképződést, az interglaciális és az interstadiális szakaszok pedig futóhomok-képződést eredményeztek. Molnár (1965) pleisztocén üledékeinek nehézásvány-összetétel vizsgálatával elemezte a lehordási irányokat, melyben a Duna-Tisza köze északi és déli része jelentősen elkülönül.

A fentebb említettek alapján az látszik, hogy a terület kialakulásával kapcsolatosan a területet vizsgáló földtanos és földrajzos kutatók eddigi kutatási eredményeik alapján különböző álláspontokat képviselnek, melyeknek tisztázása a jövő feladata.

A Duna-Tisza köze déli részének részletesebb (felszín és sekély) földtani vizsgálatai az 1950-es évektől kezdődően Miháltz (1950), majd később Rónai (1985) munkájából ismeretesek, valamint a MÁFI 1970-es évektől zajló részletes Alföld-kutatása (9. ábra) során zajlottak.

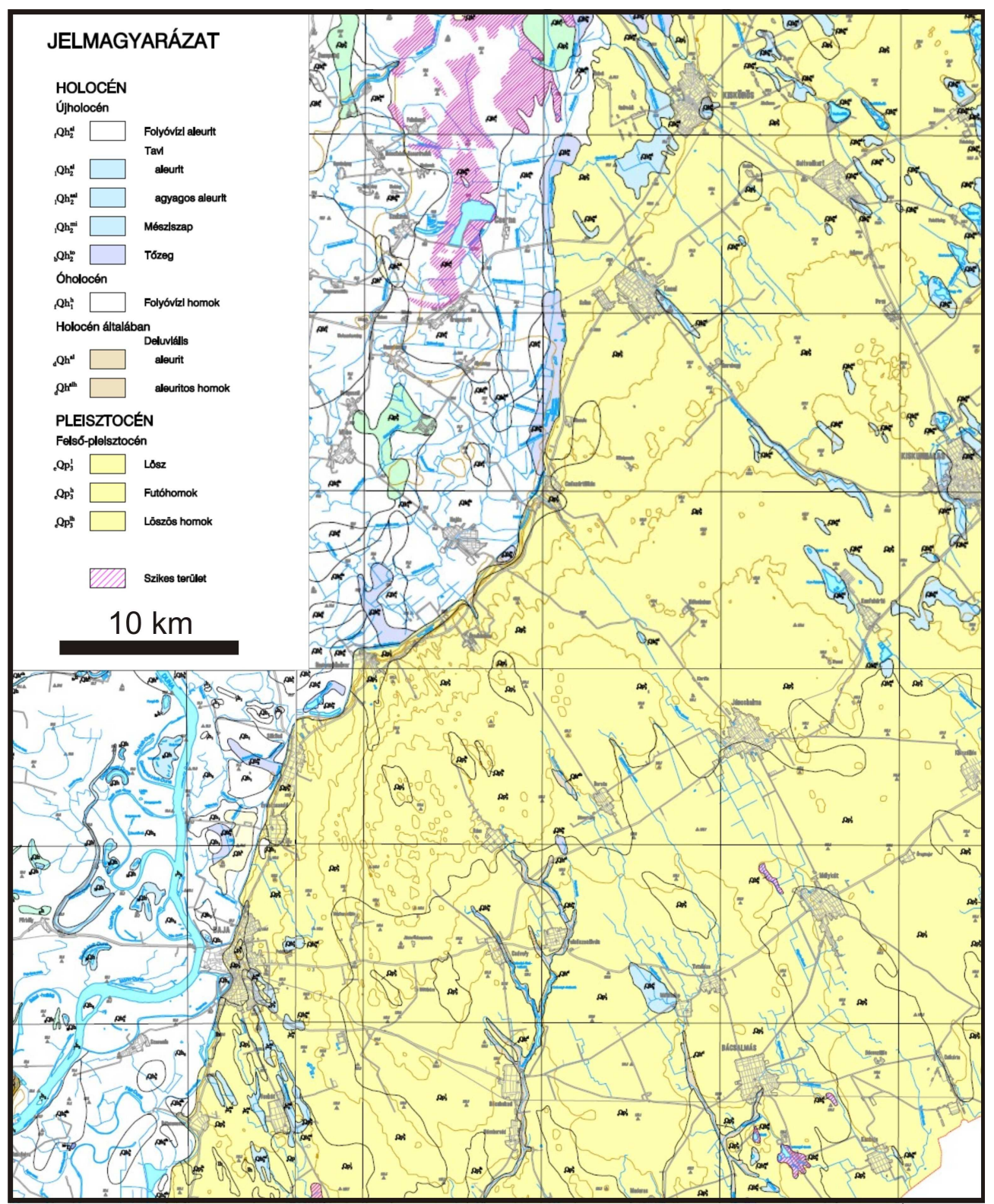

9. ábra. Az Alföld DNy-i részének felszíni üledéktípusai (forrás: MÁFI) 
a.

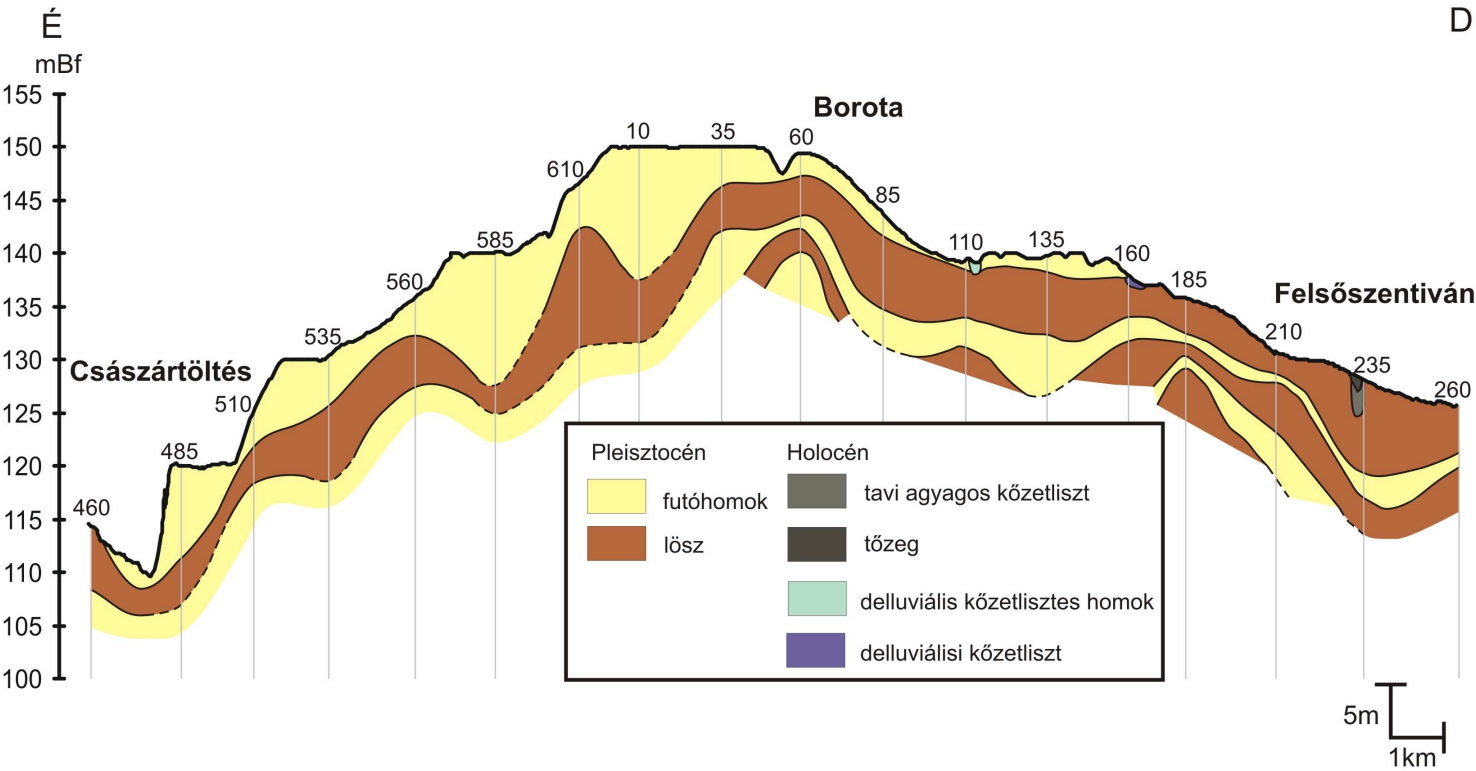

$b$.

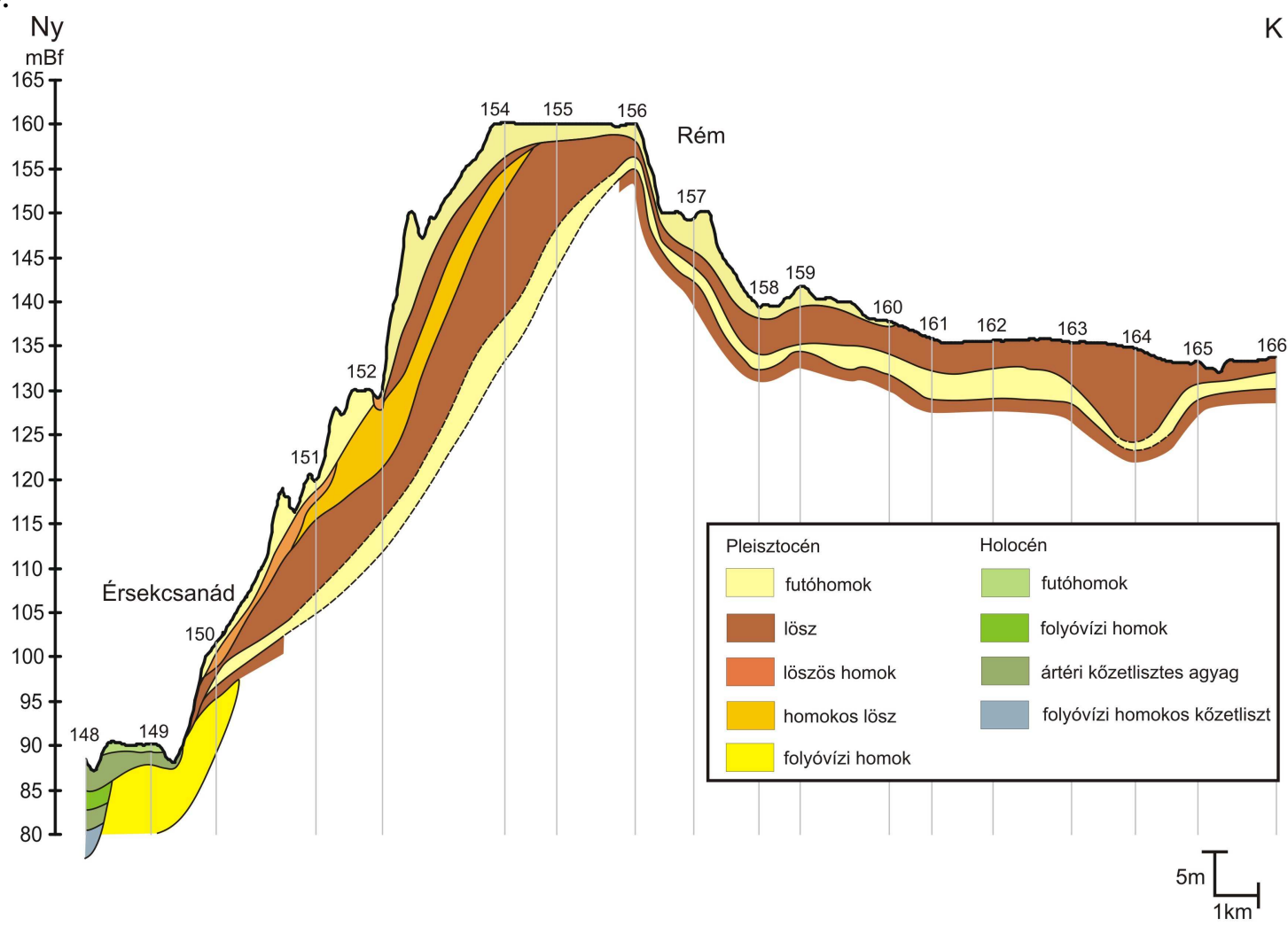

10. ábra. Keresztszelvények az Illancson

a. É-D-i keresztszelvény $b$. $N y-K$-i keresztszelvény

(A MÁFI adatai alapján szerkesztette: Kuti L., Ladányi Zs.. További szelvények az 1. mellékletben)

Az Illancs területét zömmel futóhomok, kisebb területen lösz illetve homokos lösz borítja, valamint a felszín alatt is változó mélységben és vastagságban is ezen üledékek rétegződnek (10. ábra). A Kecel-Bajai magaspart mentén húzódó területeken a lösz a felszínre bukkan, majd kelet felé a felszínt borító futóhomok-réteg egyre vastagabbá válik. A 
negyedidőszaki üledékek együttes vastagsága is kelet felé nő (Molnár 1977, Franyó 1994). Holocén üledéket csak elenyésző kiterjedésben, a buckamezők közötti mélyedésekben találunk, melyek a környező, magasabban fekvő területekről a szél és víz által felhalmozott kőzetanyagból jöttek létre (pl. delluviális kőzetlisztes homok).

A kistáj nyugati oldalán az üledéktípusok és a tengerszint feletti magasság egyértelmüsíti a tájhatárt. A mai Kalocsai-Sárköz kistáj a kalocsa-mohácsi süllyedék erőteljes tektonikus mélyülése nyomán vált a Duna árterévé, területét holocén üledékek borítják. A kistáj keleti részén a felszíni futóhomokot felváltja a lösz (Bácskai löszös síkság). A löszköpeny alatt megfigyelhető futóhomok-rétegek egyértelmüen jelzik a két terület szoros összetartozását.

A kistáj nyugati részén, a Duna-völgy felé több helyen figyelhetünk meg deráziós völgyeket (11. ábra), melyeket az interglaciálisok bỏvebb csapadékmennyisége hatására kialakult időszakos vízfolyások alakítottak ki (Miháltz 1950, Molnár - Balázs 2009). Ezek több helyen - a vékony futóhomok-borításnak köszönhetően - feltárták a futóhomok alatt lévő löszrétegeket.

A futóhomok zöme a pleisztocén utolsó harmadában alakult ki és halmozódott fel, de felszínük a holocénben is tovább formálódott. Igen jól osztályozott, uralkodó szemcsenagysága a 0,1-0,2 mm, melynek súlyaránya gyakran eléri a 70-80\%-ot is. Helyenként megfigyelhető az uralkodó széliránynak megfelelően bizonyos mértékü finomodás a futóhomok szemcsékben. A futóhomok a Duna-Tisza közén mészben és magnéziumban gazdag, a karbonát-tartalom eléri a 15-20\%-ot (ellentétben a Nyírség mésztelen, savanyú homokjával) (Rónai 1985). Kialakulásában szerepet játszottak a futóhomok alapanyagát adó folyók vízgyüjtő területének kőzetei, valamint a jelentős nagyságú mészgazdag löszrétegek. A lösz legtöbbször típusos lösz, illetve finomhomokos lösz, melynél az uralkodó löszfrakció $(0,02-0,05 \mathrm{~mm})$ mellett a vele szomszédos finomhomokra nagyobb mennyiség jut, mint a löszfrakcióknál finomabb szemcsékre, így a görbének az uralkodó szemcsenagyságot feltüntető része kissé a finomhomok felé tolódik el, de még mindig 0,02-0,05 mm közé esik. A löszös üledék vastagsága a Duna-Tisza közi homokhátságon 3-5 m körüli, a bácskai területen azonban a 10 m-t is meghaladja (Miháltz 1950, Molnár - Balázs 2009).

A Duna-Tisza közén a löszben több karbonátásvány van, mint a homokban (Molnár 1980, Szendrei 1977, Kerék 2003). Fügedi és munkatársai (2005) kimutatták, hogy a karbonátásványokat a Duna-Tisza közére nem a Duna árteréről, hanem a Dunántúli középhegységből fújta oda a szél. Az eljegesedések idején a kőzetport a krioturbáció hozta a felszínre. A szélhordta kalcit- és dolomitpor belekeveredett a hátságon lerakódó löszbe és 
homokba. A löszben azért több a karbonátásvány, mert a mészkő- és dolomitpor uralkodóan kőzetliszt szemcseméretü.

Az üledékföldtani vizsgálatok bebizonyították az eolikus folyamatok jelentőségét a területen. Az uralkodó ÉNy-DK irányú szelek felszínformáló hatására a jellegzetes futóhomok-formák közül a parabolabuckák (az Illancs déli részén hajtüszerü parabolák), a garmadabuckák, a szélbarázdák és a maradékgerincek dominálják a felszínt. Az akkumulációs homokmezőben a garmadák összetorlódása is megfigyelhető. A homokformákból álló felszínek jelentősen különböznek egymástól, hiszen kialakulásukat a szélirány, szélerősség és a felszín növényzettel való fedettsége befolyásolta (Borsy 1977).

A kistáj arculata az élőhelyek szempontjából kettős. A magaspartot övező területeken löszsztyepprétek (Festuca rupicola, Taraxacum serotinum, Astragalus exscapus, Hypericum elegans), valamint a homokterületeken a nyílt homokpusztagyepek (Festuca vaginata, Stipa borysthenica, Alkanna tinctoria, Dianthus serotinus, Onosma arenarium, Centaurea arenaria, Colchicum arenarium) és a homoki sztyepprétek (Festuca rupicola, Stipa capillata, Crysophogon gryllus, Adonis vernalis, Allium moschantum, Vinca herbacea) jellemzőek (Pándi 2008). A nyugati peremén húzódó jó termőtalajú, lösszel fedett magaspartját már évszázadokkal ezelőtt művelésbe vonták, ezért a természetes (illetve természetközeli) löszvegetáció csak a meredek partoldalon illetve az ÉNy-DKi lefutású löszvölgyek oldalain maradt meg (11. ábra). A természetes homoki élőhelyek az erdőtelepítés előretörésével és a kistáj homokterületeinek müvelésével fragmentálódtak, kiterjedésük töredékére csökkent.

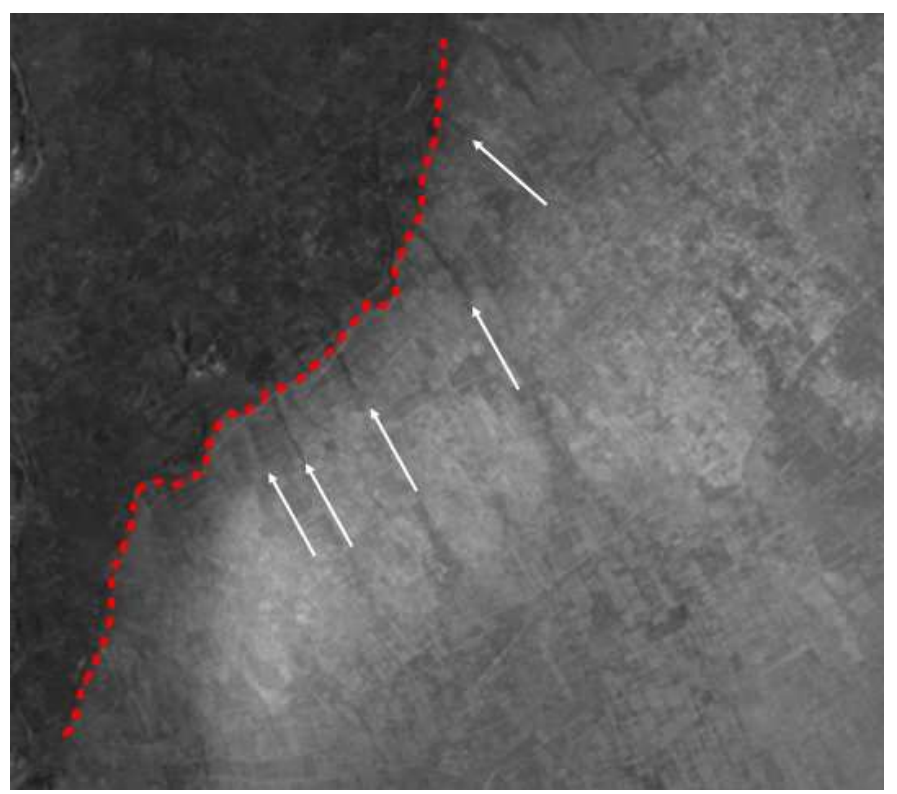

11. ábra. Illancsi löszvölgyek a kistáj digitális domborzatmodelljén (ASTER GDEM) (A piros vonal a Kecel-Bajai magaspart meredek peremét ábrázolja) 
A hátsági vizes élöhelyek mintázata, geomorfológiai helyzetéből adódóan egészen a legutóbbi évtizedekig fennmaradt, viszont az utóbbi húsz év vízhiányos állapotából következően az élőhelyek jellegtelenedése tapasztalható, miközben az antropogén élőhelypusztítás intenzitása is növekedik (Bíró 2006). Domborzati helyzetükből adódóan az Illancs peremén lévő időszakosan vízzel borított területek elsőként váltak a szárazodás valódi áldozataivá, az 1980-as évek óta száradnak és jellegtelenednek. Az egykori időszakos vízborítás miatt ezeken a területeken szántógazdálkodást nem folytattak, ezek legelőként funkcionáltak (egyes esetekben még funkcionálnak ma is, lásd később a borotai mintaterület esetén). A kiszáradáshoz és a vízhiány kialakulásához jelentősen hozzájárultak a csatornák, melyeket a belvízrendezés időszakában a „felesleges vizek” elvezetése céljából mélyítettek.

Az Illancs futóhomokkal fedett buckavonulatai az uralkodó széliránynak köszönhetően ÉNy-DK irányúak, és ujjszerüen nyúlnak el a Bácskai löszhát irányában. Talajai döntően futóhomokos váztalaj illetve humuszos homok kategóriába sorolhatóak. A magaspartot övező területeken alföldi mészlepedékes csernozjom talajok is elöfordulnak. A kistáj keleti peremén húzódó mélyedéseket döntően réti talajok jellemzik, és az agrotopográfiai adatbázis egy szoloncsák-szolonyec foltot is jelöl Borota közelében. A környező magasabban fekvő buckákról érkező vizek (csapadék-talajvíz) ezekben a laposokban összegyülnek és a jobb víztartó képességü talajoknak köszönhetően, nem szivárognak azonnal a mélybe. Az időszakos vízborítás következtében és a talajvíz sótartalma függvényében szikes illetve lápi élőhelyek alakultak ki rajtuk. A jelentős vízborítás hatására e területeket nem vonták mezőgazdasági müvelés alá, általában legelőként és kaszálóként használták őket. E területek jelentős vízborítására a második és a harmadik katonai térképezések szelvényein találunk bizonyítékokat (12. ábra).

A laposok vizének forrásai a lokális áramlási rendszerek, valamint a hátság magasabb részei felől érkező regionális felszín alatti talajvíz-áramlások. A Duna-Tisza közi hátság ezen a részén pozitív nyomásgradiens és a lefelé tartó vízmozgás a jellemző (Völgyesi 2006), így a mélységi vizek feláramlási zónái bizonyosan nem táplálják ezeket a mélyedéseket (13. ábra). 


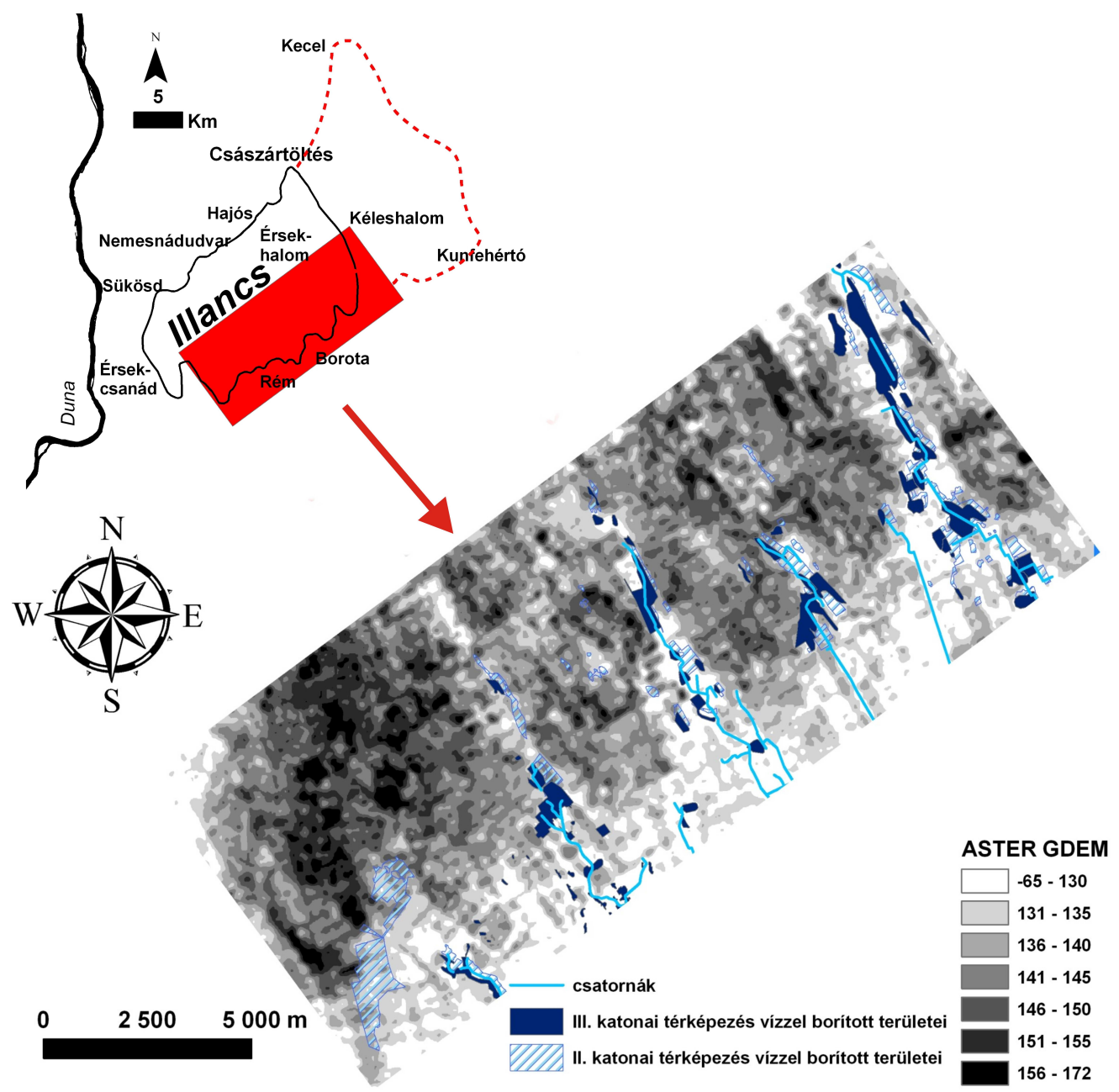

12. ábra. Az Illancs és a Bácskai löszhát peremén lévő időszakosan vízzel borított területek

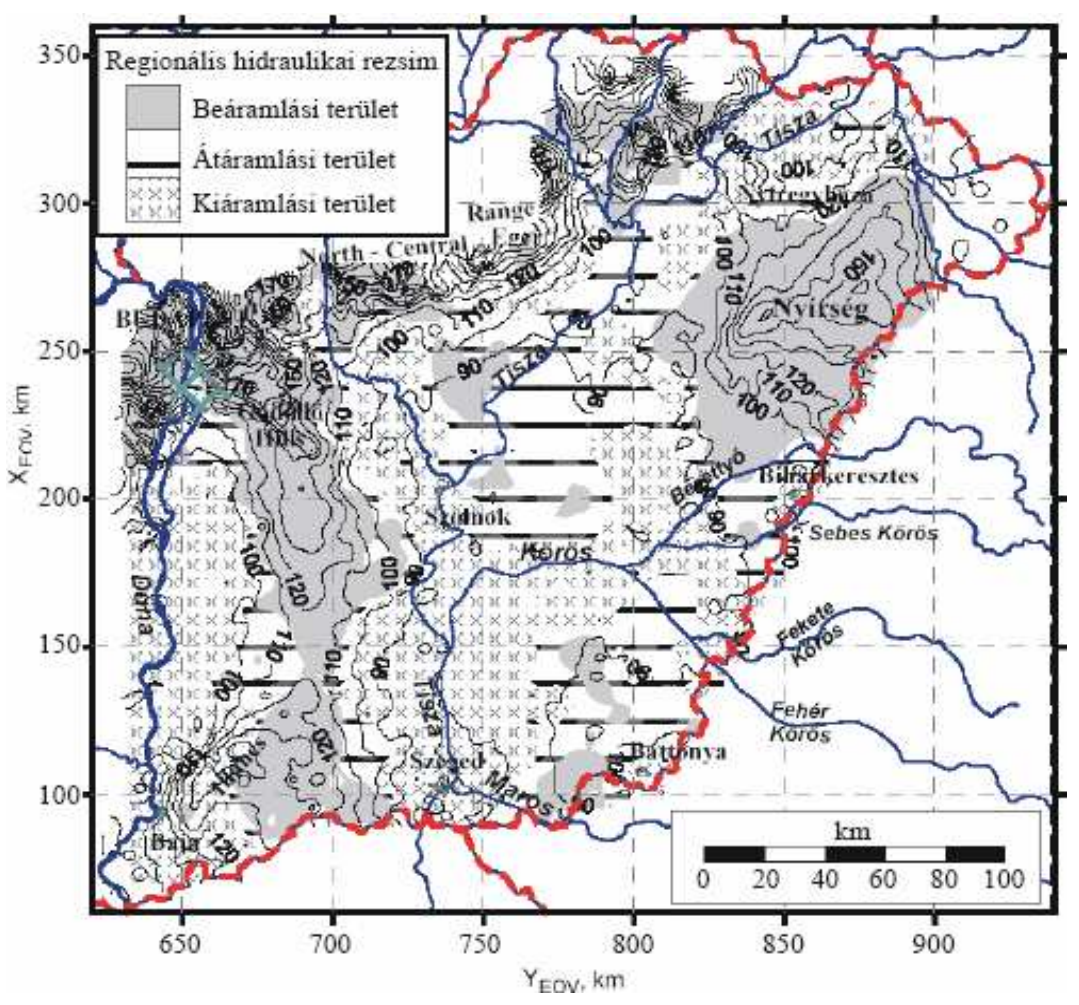

13. ábra. Hidraulikai rezsimek eloszlása az Alföldön (Almási 2001) 


\subsection{Illancs kistáj és az elhatárolhatóság korlátai}

A tájelhatárolás nehézségei már az 1960-as években lezajló, Magyarország természeti földrajzi tájbeosztásáról szóló vitában is megmutatkoztak. A „Bácskai-lösztábla” (így közvetve az Illancs is) a tájbeosztás-tervezetekben már más-más határvonallal szerepelt (Góczán 1961). A konszenzusos határvonal meghúzását követően az 1980-as évek végére az Illancs (és így a középtáj) lehatárolásának szakirodalmában újra disszonancia jelent meg. Mivel a dolgozat kistáj szintü elemzésekre vállalkozik, elengedhetetlen egy határvonal definiálása. Ezen alfejezet számba veszi és értékeli a szakirodalomban vett különböző tájhatárokat, azokat térképi és egyéb adatforrásokkal igyekszik alátámasztani. A további értékelésben a táj mai természeti földrajzi értelmezés szerint vett definíciója jelenik meg, amely szerint a táj a földfelszín meghatározott részlete, mely megjelenése és müködése alapján a szomszédos területektől (tájaktól) elkülönül (Pécsi et al. 1972). Olyan funkcionális egység, aminek természetes működésébe az ember beavatkozik, ugyanakkor annak maga is része.

\subsubsection{A kistáj elhatárolása a szakirodalomban és annak vitatható pontjai}

Bács-Kiskun megye területén elhelyezkedő kistájunk a Marosi - Somogyi féle kistájkataszter definíciója alapján buckás felszínü futóhomokkal fedett hordalékkúp-síkság (Marosi - Somogyi 1990a), határát Rémtől Érsekhalmáig, valamint Sükösdtől az Alsókélesivölgyig határozza meg. Hasonló határvonal szerepel a Magyarország Nemzeti Atlaszában a kistájak természeti adottságait a szántóföldi növénytermesztés szempontjából értékelő térképeken is (Mezősi 1989). Azonban a fentebb említett 1990-es kistájkataszter (Marosi Somogyi 1990b) térképmelléklete már a Kecel-Kunfehértó vonalat jelöli kistáj-határként (14. ábra). Ugyanez a határvonal jelenik meg a Magyarország Nemzeti Atlaszában a természeti tájak rendszertani besorolásánál is (Keresztesi et al. 1989). Később a MTA TAKI GIS laborja is ezt a térképet digitalizálta (Földrajzi kistájak é. n.) (2. melléklet).

Nebojszki (2004) ismeretterjesztő cikkében az Illancs keleti határaként a Császártöltés-Kiskunhalas vonalat említi. Bíró és munkatársai (2007) a Duna-Tisza köze vegetációs kistáj-beosztásának elkészítésekor az Illancs és a Bácska, valamint a Kiskunsági Homokhát közötti határt úgy húzták meg a vegetáció vizsgálata alapján, hogy a Kéleshalmihomokbuckák területét és Kunfehértó környékét nem sorolják az Illancshoz (15. ábra). 


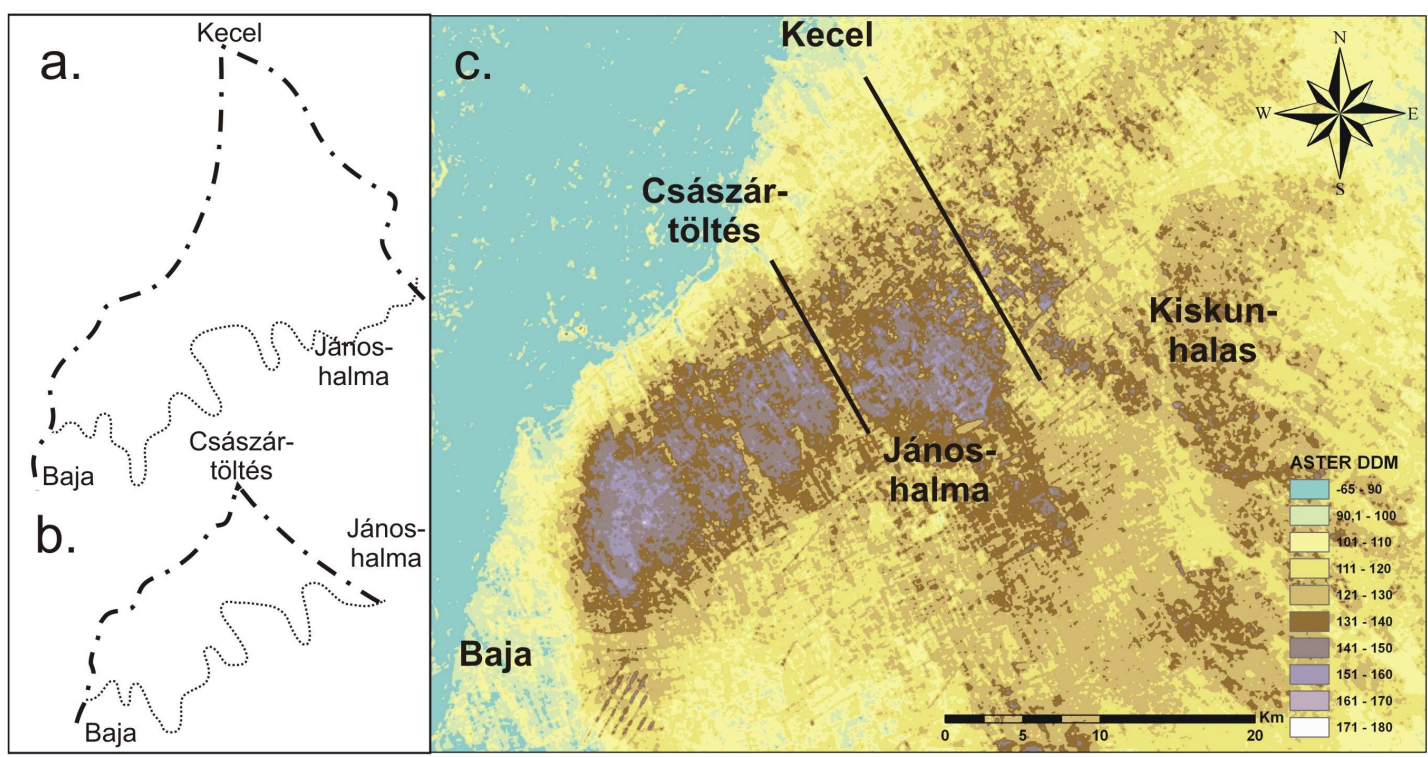

14. ábra. Az Illancs határa

a. Marosi - Somogyi féle kistájkataszter térképmelléklete szerint; b. Marosi-Somogyi kistájkataszter szerint; c. Illancs domborzata (ASTER DDM) feltüntetve a két határvonalat

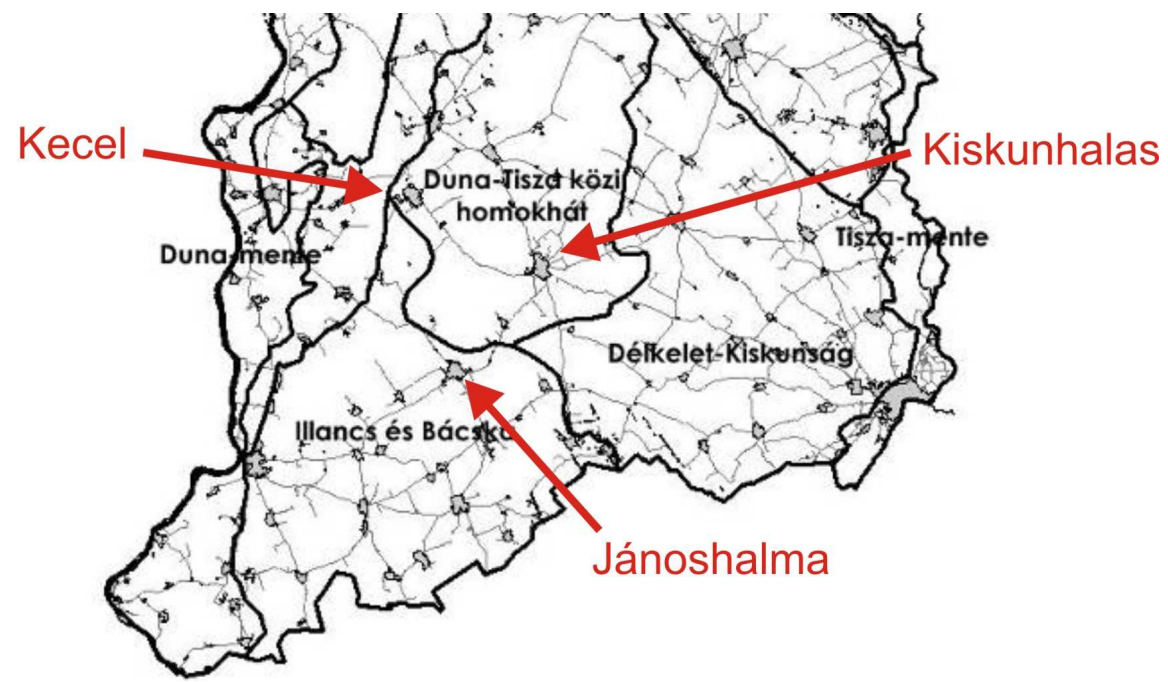

15. ábra: A vegetációs kistájak elhelyezkedése a Duna-Tisza közén (Bíró 2006)

Molnár és munkatársai (2008) Magyarország vegetációtájainak elhatárolásánál pontosították a vegetáció tekintetében a Homokhátság határát, így az Illancs déli határa is a megelőző irodalmakhoz képest módosításra került. A Borota terepülést övező jelentős beszögellés (Antallapos) például, melyet a Marosi - Somogyi féle kistájkataszter jelzett, ezen már nem szerepel (3. melléklet). Az Antallapos nevét Grassalkovich Antalról kapta (Farkas 2004), valószínűleg a környező buckákhoz képest mélyebb fekvése miatt.

A kistájkataszter 2010-ben módosításra, és újra kiadásra került (Dövényi 2010). Ez az irodalom a kistáj határát ismételten a Császártöltés-Jánoshalma vonalon húzza meg. 
Az ÉK-i és DNy-i határvonal kérdéskörében a MÁFI földtani térképei a KecelKunfehértó határvonalat támasztják alá (lásd 9. ábra), hiszen ettől a vonaltól északkeletre a mésziszapos völgyek sokkal jelentősebb kiterjedésűek és számúak, és ugyanígy az Illancs déli részén, Bajától délre is. A Jánoshalma-Császártöltés határvonal elválasztó jellegét az I. katonai térképezés szelvénye igazolhatja, amely e vonalnál jelentős kiterjedésủ lápréteket és tavat (Kélesi-tó) jelöl (16. ábra). A Kélesi-tó völgyeletének folytatása Császártöltés felé a Szamárvölgy, ami szintén e völgyelethez tartozik.

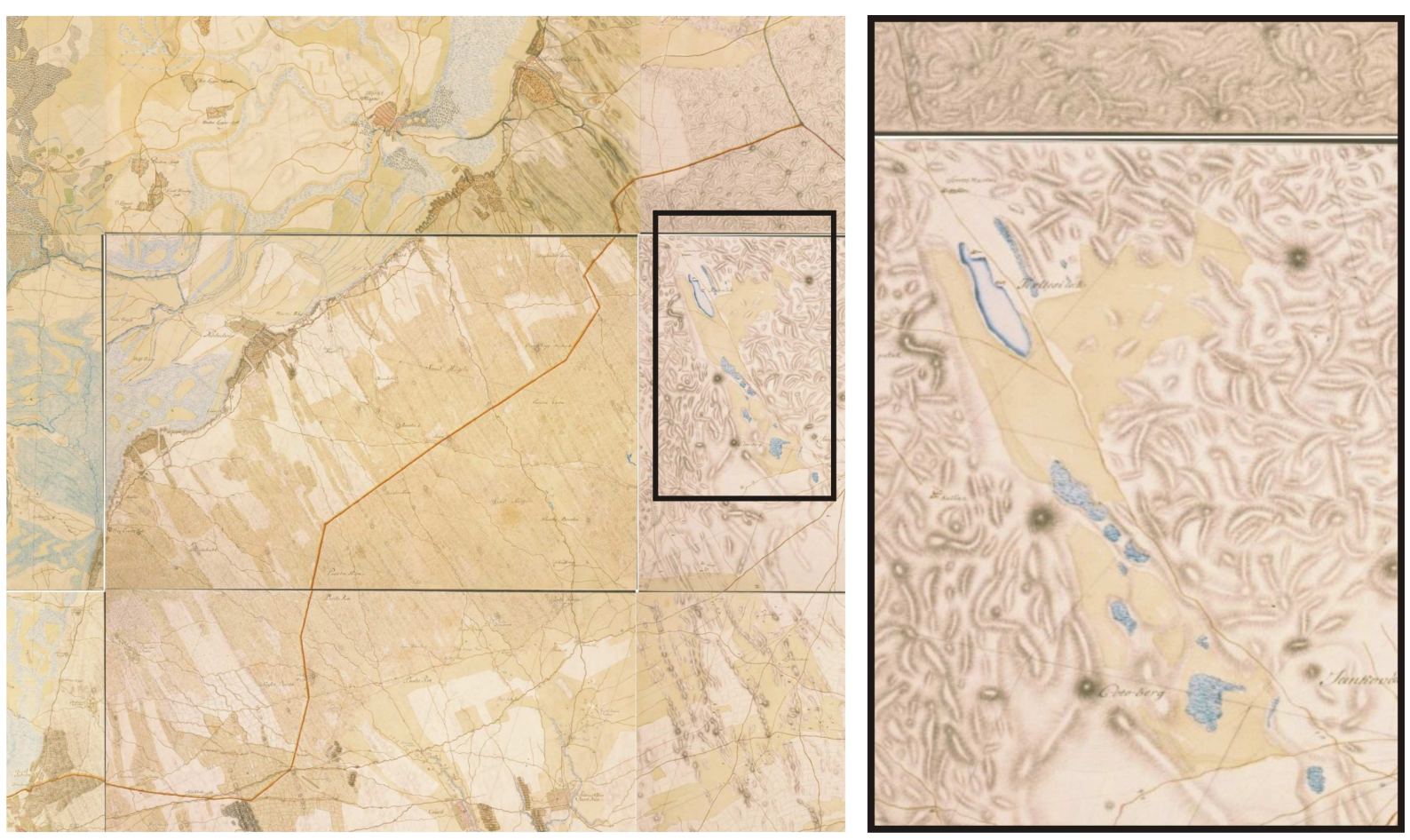

16. ábra. Az I. katonai térképezés illancsi szelvényei

(kiemelve a Jánoshalmától északkeletre húzódó lápréteket és a Kélesi-tavat)

A botanikai vizsgálatok azt mutatják, hogy a hátság buckavidékei jelentősen különböznek egymástól. Amíg a Duna-Tisza köze É-i részén (Kunadacs környékén) közönséges boróka (Juniperus communis) és szürke nyár (Populus canescens) jellemzi a buckákat, addig a Homokhátság D-i részén a fehér nyár (Populus alba) és az egybibés galagonya (Cragateous monogyna) fordul elö. A kettő közötti átmenetet képviseli a Kéleshalmát övező buckavidék, ahol az egybibés galagonya, a közönséges boróka, a szürkenyár és a fehérnyár egyaránt megtalálható (TIR 2010).

A kistáj Kecel-Bajai-magaspart mentén húzódó, lösszel fedett területének eltérő adottságait már az 1980-as évek végén felismerték (Rónai 1985, Jakucs et al. 1989, Várallyay et al. 1980, 4. melléklet), mégis - a futóhomok borította hordalékkúp-síkság definíció ellenére - az Illancshoz sorolták. 
Az eddig bemutatott elhatárolások az északnyugati határvonal tekintetében összességében egységes képet mutattak: nagyjából Kecel-Bajai magaspart vonalában jelölték ki Illancs északnyugati határvonalát, mely tulajdonképpen a pleisztocén üledékek (futóhomok, lösz), valamint a Duna-völgy felé a holocén üledékek határát jelenti. A délkeleti határvonal tekintetében Borota település környezetében mutatkoznak vitatható pontok. A MÁFI földtani térképei, és a Kreybig felvételezés segítségével, valamint terepi felmérésekkel ez a határvonal pontosítható. A délnyugati határvonal a megelőző irodalomban nagyjából egységesnek tekinthető. A legnagyobb eltérések az északkeleti határvonal esetében, a kéleshalmi homokbuckák területének hovatartozásában mutatkoztak. A homoki növényzet tekintetében a két határvonal esetében különbség csak a közönséges boróka (Juniperus communis) meglétében (illetve hiányában a rémi, borotai homokbuckákon) tapasztalható. Azonban a borókáról feljegyzések csak kb. 200 év óta állnak rendelkezésre (Molnár 2003b), tehát e tényező önmagában nem szolgálhatja egyételmüen a határvonal tisztázását.

\subsubsection{A kutatás megállapításai a kistáj elhatárolásának pontosításához}

Mindezek alapján elmondható, hogy Illancs kistáj elhatárolása nem egységes a szakirodalomban. Ennek oka valószínüleg a terület alulkutatottságában keresendő, pontosítása a jövőbeni kutatások egyik célfeladata lehet. A begyüjtött információk alapján a következő megállapítások tehetők:

- Az elhatároláshoz felhasználható jelenleg elérhető, felszínföldtani információkat nyújtó források nem elegendőek a terület pontos elhatároláshoz. A MÁFI földtani térképein és a Kreybig-féle Átnézetes Talajismereti Térképsorozat szelvényein különbözik a homok és a lösz határvonala, amelynek oka a fúrások sürüségében és a mintavételezés gyakorlatában keresendő. A Kreybig felmérés esetében mintavétel illetve laborelemzés alapján, hasonló vegetációs és domborzati körülmények figyelembe vételével határolták el egymástól a különböző (talaj) foltokat. A MÁFI kutatófúrások 1, illetve 4 km-ként történtek, közel szabályos háló alapján, amelyekből szintén csak közelítő pontosságú térképek keletkezhettek. Terepbejárással a déli határvonalat a Baja-Jánoshalma szakaszon pontosítottam (17. ábra), döntően a felszíni üledékek típusa és vele összefüggésben a tájhasználat alapján. Természetesen a valós tájhatár egy vonalnál sokkal szélesebb ökoton zónát takar, de az irodalmi adatokhoz képest a valósághoz ez az elhatárolás állhat a legközelebb, mely a további értékelésekhez alapadatként szolgál. 


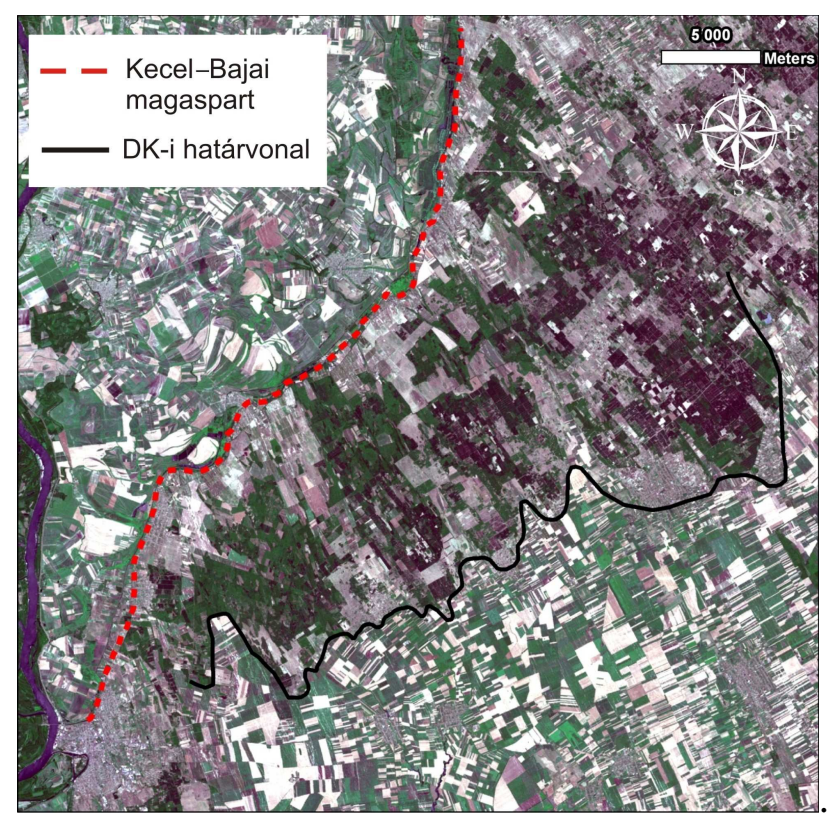

17. ábra: A pontosított határvonal (fekete vonal)

- Az akkumulációs homokmezők végénél a futóhomok jól elkülönül a jó termőképességü, nagy kiterjedésű bácskai szántók uralta lösztakarótól (18. ábra). A tereprendezések nyoma a Rém-Borota közötti határvonal hullámosságán is megfigyelhető ott, ahol egykor szőlősök-gyümölcsösök borították a felszínt. Sok esetben a mai tájhasználat egyértelmüen kijelöli a homok-lösz határvonalat.

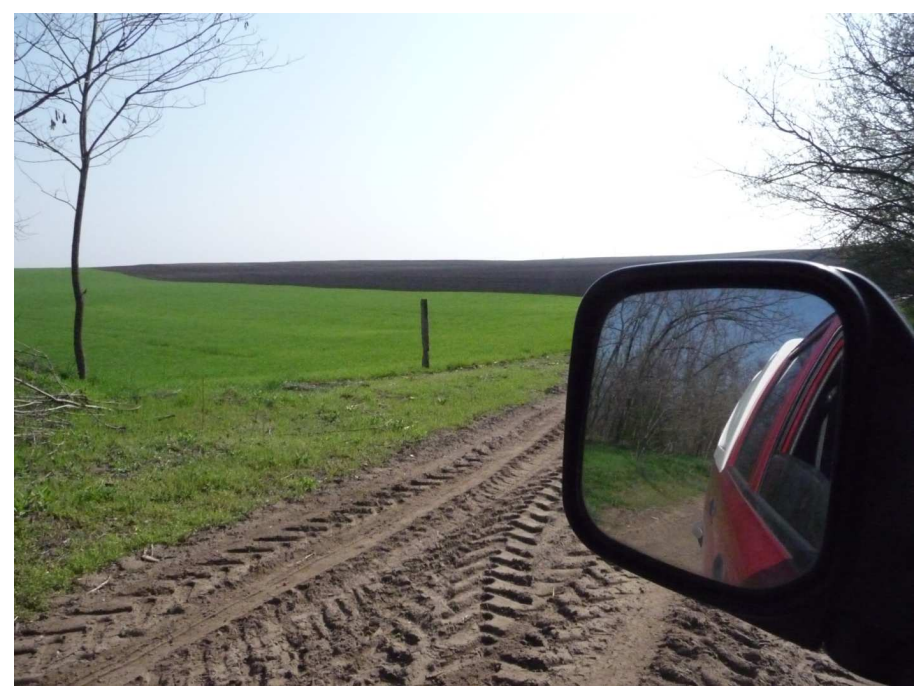

18. ábra. A határvonal egy egyértelmü esete

(A tükörben mutatkozó háttérben egy homokon telepített akácos, a terepjáró még homokon áll, a kép bal oldalán középen egy régi szőlőbirtok sarka (vékony homoklepel) és a távolban már hatalmas bácskai szántók)

- A délkeleti határvonal egy érdekes kérdése a buckavonulatok közötti, egykoron vízzel borított mélyedések hovatartozása. Egyértelmü tény az, hogy a buckamezők (vagy akár a buckák) sohasem választhatóak el a hozzájuk tartozó mélyedésektől. Így van ez az Illancs délkeleti peremén is (19. ábra). Azonban ez a megállapítás több kérdést hordoz ma- 
gában. Hol húzódik ezeknek a mélyedéseknek a határa? Honnantól kezdődik a Bácskailöszhát? Hiszen ezekben a mélyedésekben a felső pár dm-ben fordul elő csak futóhomok, az alapkőzet lösz, amelyen döntően réti talajok alakultak ki. Az elhatárolásban segítséget nyújt az a tény, hogy a Bácskai löszhát vizes élőhelyei a terepen is jól meghatározható löszvölgyekben találhatóak. Az Illancs DK-i részén a buckaközökben egymástól jól elkülönülő, diszkrét mélyedésekben találjuk meg ezeket a vizes élőhelyeket, melyek előfordulása alapján húzható meg a határvonal. A dolgozat további részében egy ilyen buckavonulatok közötti „,völgyelet” az 5. és 6. fejezetben részletesebben is elemzésre kerül.

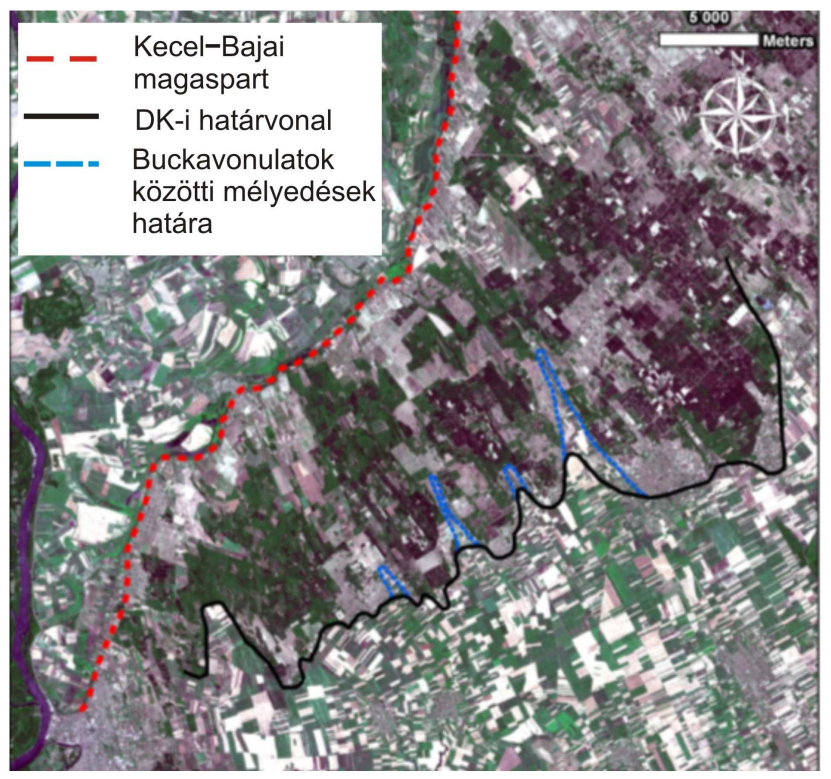

19. ábra. Az Illancs módosított délkeleti határvonala, feltüntetve a buckaközi mélyedéseket

- A buckavonulatok közötti „,völgyeletek” közül az egyik legkiterjedtebb Jánoshalma belterületétől ÉNy-ra, egy ÉNy-DK irányú mélyedésben húzódik meg. Ebben található a Kélesi-tó is, amely az elmúlt évtizedek vízelvezetésének köszönhetően mára teljesen kiszáradt, de még az 1970-as években is horgásztak benne. Ez a terület mélyen benyúlik a Homokhátság területébe, melynek a folytatása egy deráziós völgy (Szamárvölgy), mely egészen Császártöltésig húzódik. A másik tájhatár-elképzelés szerint egy hasonló ÉNy-DK irányú völgyelet a határ, amelyben a Kunfehér-tó és a Bogárzó található. További részletes összehasonlító, üledékföldtani vizsgálatok szükségeltetnek, hogy a legnagyobb biztonsággal a két határvonal alapján történő lehatárolás között állást lehessen foglalni.

- A borotai Antallapos kihagyása az Illancs területéből nem lehet valós elhatárolás. A Marosi - Somogyi féle kistájkataszter mindkét határvonalának meghúzásakor valószínűleg súlyozottan szerepelt Magyarország 1972-es geomorfológiai térképe (1:500.000) (Pécsi 1972) (20/a. ábra), melyen a sárga különböző árnyalatai jelzik a „futóhomokkal és lösszel borított hordalékkúp-síkságot”. A terepbejárás során (illetve a Kreybig és a földtani térké- 
pek alapján is) egyértelmüen látszik, hogy Borota község belterületén egészen a templom vonaláig futóhomok borítja a felszínt. Ráadásul a Marosi - Somogyi (1990a) és a Dövényi (2010) szerinti, a szükebb értelemben vett Illancs elhatárolás szerint az egyetlen fennmaradt, látványos homokbuckákkal tarkított, védett terület, a Hajósi Homokpuszta Természetvédelmi Terület épp a táj határán lenne (20/b. ábra).

$a$.

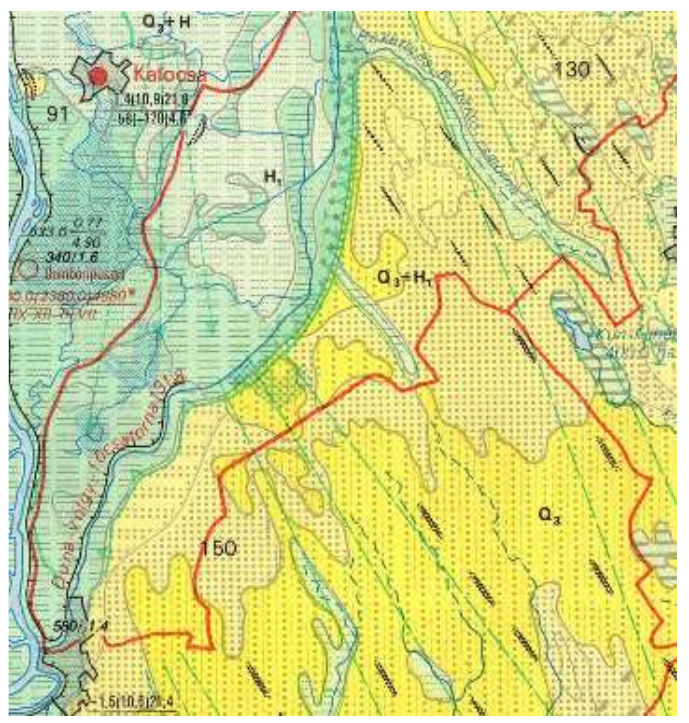

b.

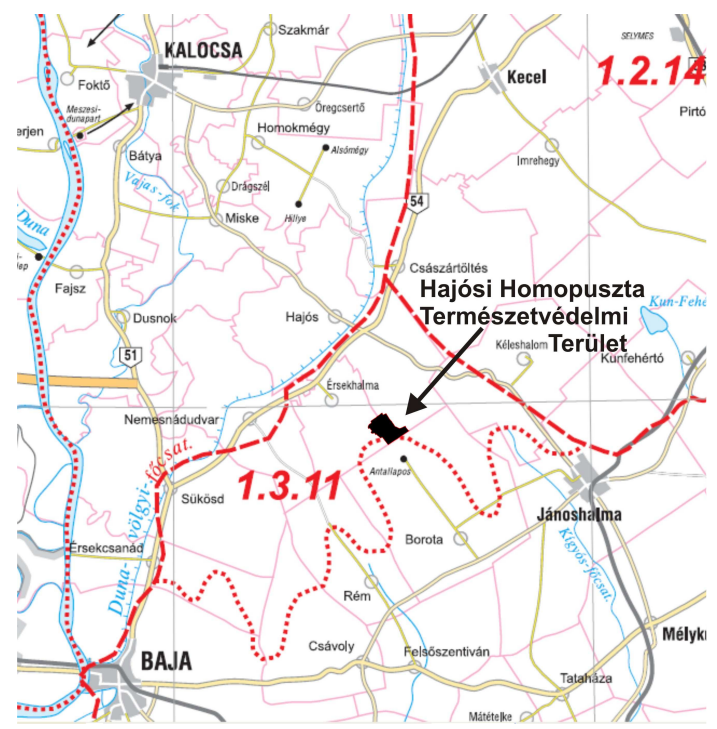

20. ábra. a. Magyarország geomorfológiai térképének kivágata (Pécsi 1972); b. a kistáj határa az új kistájkataszter alapján (Dövényi 2010), rajta a védett Hajósi Homokpuszta TT-el.

- A földtani térképeken megjelenő mésziszapos völgyek kiterjedése (vagy akár ugyanez a geomorfológiai térképen a 20/a. ábrán az északi határ tekintetében) egyértelmű elkülönítő bélyeget nyújthat (lásd 9. ábra). Ezeken a térképeken jelentős kiterjedésben azok Kecel-Kunfehértó vonaltól É-ra, valamint Baja környékén a Babinadola vonalától D-re figyelhetőek meg. Önállóan azonban ez sem lehet az elhatárolás alapja, hiszen a földtani kutatófúrások csak 1-4 km-ként történtek meg a hetvenes években, ahol előfordulhatott, hogy a kisebb kiterjedésü völgyek így az értékelésből kimaradtak és a 100.000-es méretarányú térképeken egyszerüen generalizálódtak.

- A térség talajvízszint-süllyedését ábrázoló részletes térképek a tengerszint feletti magasságoknak megfelelően a Kecel-Kunfehértó határvonalat támasztják alá (21. ábra).

Mindezen információk alapján, ragaszkodva a kistájkataszterekben rögzített definícióhoz (futóhomok borította hordalékkúp-síkság), az Illancs kistájat a mai (szűkebb) értelmezés szerint a következőképpen lehetne jellemezni: a Duna-Tisza köze legmagasabb, futóhomok borította területe, melyet uralkodóan galagonyás nyaras és nyílt homokpusztagyepek, valamint peremein homoki sztyepprétek borítanak. A nagyobb garmada-bucka mezöket diszkrét mélyedések tagolják, jellemzöen lápi és kisebb mértékben szikes vegetációval. Ezen kitételek alapján megkérdőjeleződik a Kecel-Bajai magaspartot övező löszperem (Császártöltés-Hajós-Érsekhalma-Nemesnádudvar, típusos lösz) 
Illancshoz sorolása. E magaspartot ugyanolyan talajtulajdonságok jellemzik, mint a Bácskai-löszhátat, vizes élőhelyei a terepen is jól meghatározható löszvölgyekben húzódnak. A Kéleshalmi-homokbuckák e definíció alapján nem tartoznának az Illancshoz, a boróka jelenléte miatt. Nincsen azonban ma elég egyértelmü bizonyíték arra, hogy ezt a szük lehatárolást bizonyosan megtehessük. A kistáj-határ tágabb verziójában 3 elkülönülő rész további vizsgálatára nyílhat mód (22. ábra). A tájalkotó tényezők vizsgálatán túl a tájhasználatváltozások, a vegetációbeli különbségek és a geomorfológia értékelésére a dolgozat 5., 6. , 7. fejezetében sor kerül.
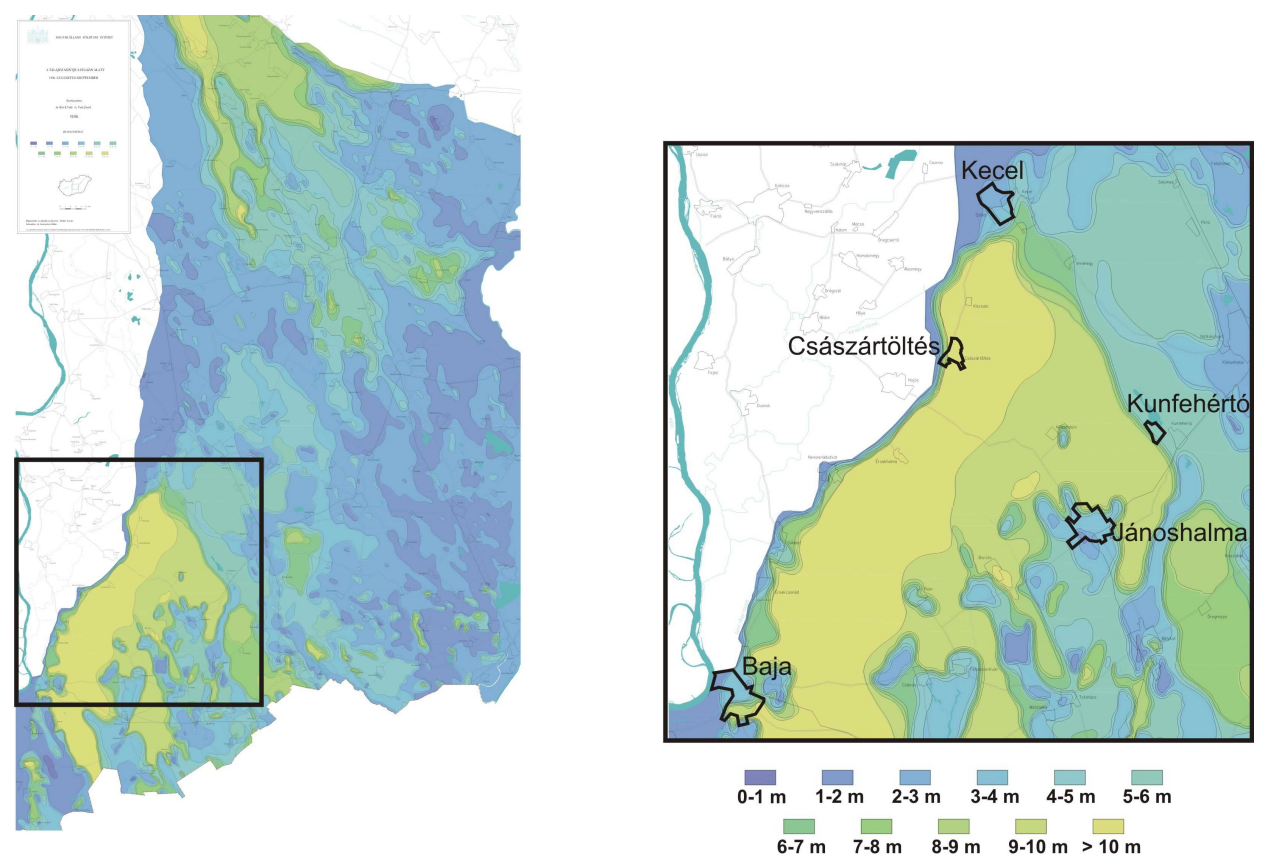

21. ábra: A talajvíz szintje a felszín alatt 1996-ban (Kuti-Vatai 1996)

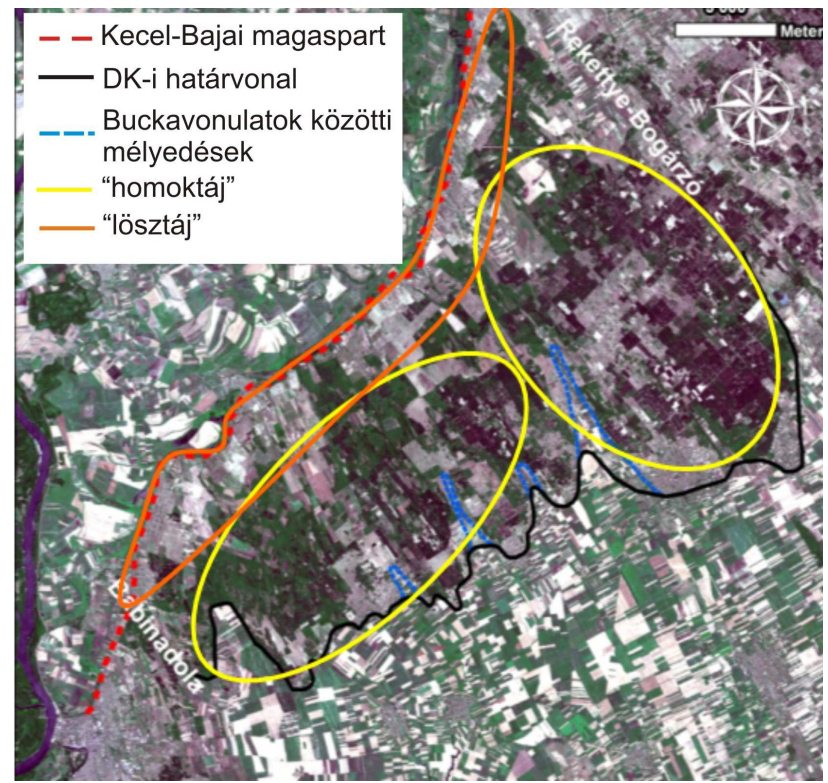

22. ábra. Az Illancs eltérőnek ítélt kistáj-részleteinek sematikus elhatárolása 


\subsection{Vízhiány az Illancson}

Az Illancshoz a legközelebb eső meteorológiai állomás (Kiskunhalas) adatai alapján számított Pálfai féle aszályossági index ${ }^{2}$ (PAI) szerint az elmúlt évtizedeket a szaporodó aszályok jellemzik (23. ábra). A legsúlyosabb aszály a 2003-as évhez kötődik, amikor a csapadék éves összege alig haladta meg a 400 mm-t a területen. Az Illancs futóhomokkal borított táján a csapadék jelentősége még inkább fokozott. A térségnek természetes vízfolyása nincs, homoktalajainak vízgazdálkodása rossz, az 1931-2009 időszak éves csapadék átlaga 586 mm/év, rendkívül szeszélyes eloszlással.

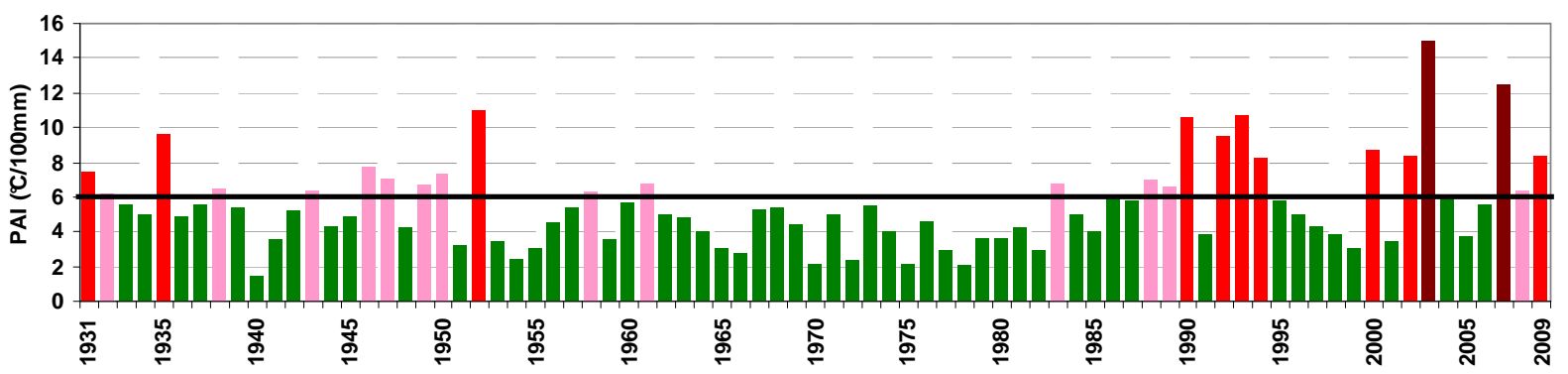

23. ábra. A PAI index értékei a Kiskunhalasi meteorológiai állomás alapján (1931-2009)

A 3. fejezet kronologikus áttekintésből jól látszik, hogy már az 1990-es évek elejére kiderült, hogy rendkívül komoly, és összetett problémáról van szó. Számos elemző tanulmány készült el, melyek a vízhiány kialakulásának okait és összefüggéseit vizsgálták. Az 1990-es évek végi csapadékos időszak hatására a talajvíz-kutakban emelkedő vízszint jelentkezett, azonban a 2000-es évek elején folytatódó süllyedési tendencia további aggodalmakra adhat okot. Különösen igaz ez azokon a területeken, ahol a legnagyobb vízszintsüllyedések figyelhetőek meg, így Borota és környéke (Illancs), ahol 2007-ben bizonyos talajvíz-kutakban a víz szintje $20 \mathrm{~m}$ alatt van (24. ábra). Az értékeléseket kissé nehezíti, hogy a vízszint-csökkenésben leginkább érintett területeken (így az Illancson is) az 1990es évek előtt kevés talajvízészlelő kút volt. Talpmélységüket az akkori aktuális viszonyoknak megfelelően alakították ki, így előfordult, hogy a régen üzemelő talajvíz-kutak „kiszáradtak”. A jelentős talajvízszint-süllyedés észlelése után - az 1990-es éveket követően egészen máig - több talajvíz-kutat mélyítettek a régióban, melyek hozzájárulnak a folyamatos monitoring rendszer pontosításához.

\footnotetext{
${ }^{2}$ Pálfai-féle aszályossági index (Pálfai 1989): az aszály mértékének számszerüsítésére az 1980-as években bevezetett aszályossági index, amely az áprilisi-augusztusi közepes léghőmérséklet és az októbertől augusztusig számított időszak súlyozott csapadékösszegeinek korrekciós tényezőkkel javított hányadosa
} 


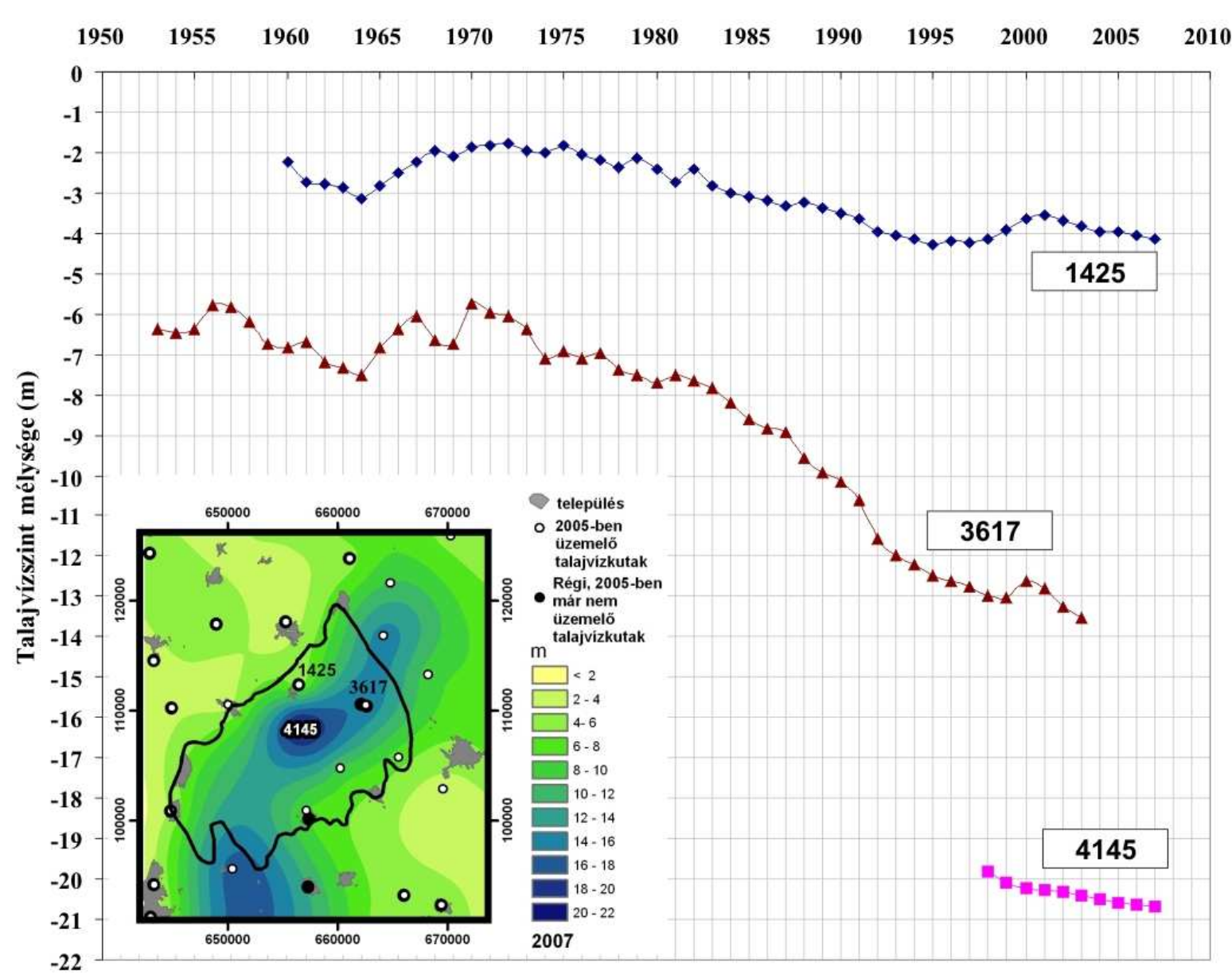

24. ábra. Talajvízszint-süllyedés az Illancson néhány törzskút esetében (a VITUKI adatai alapján)

Jogosan merülhet fel a kérdés, hogy egy olyan rendkívüli csapadékkal rendelkező év után, mint a 2010-es, egyáltalán beszélhetünk-e szárazodásról? Vajon mennyire változott meg a vízhiánnyal érintett területek kiterjedése a Duna-Tisza közén?

A sokévi átlagnál jelentősebb csapadék hatására regionális léptékben Duna-Tisza közén a 2009. november-2010. június közötti időszakban a talajvíztartóban tárolt készlet jelentős növekedése volt megfigyelhető. A 2010. szeptemberi állapotok szerint azonban az észak- és délnyugati térségek számottevő talajvízszint-süllyedése továbbra is jellemző (25. ábra), azonban ezekben az észlelőkutakban is 1-1,5 m-t emelkedett a talajvízszint a 2009 őszén mért abszolút minimumokhoz képest (Szalai 2010). 


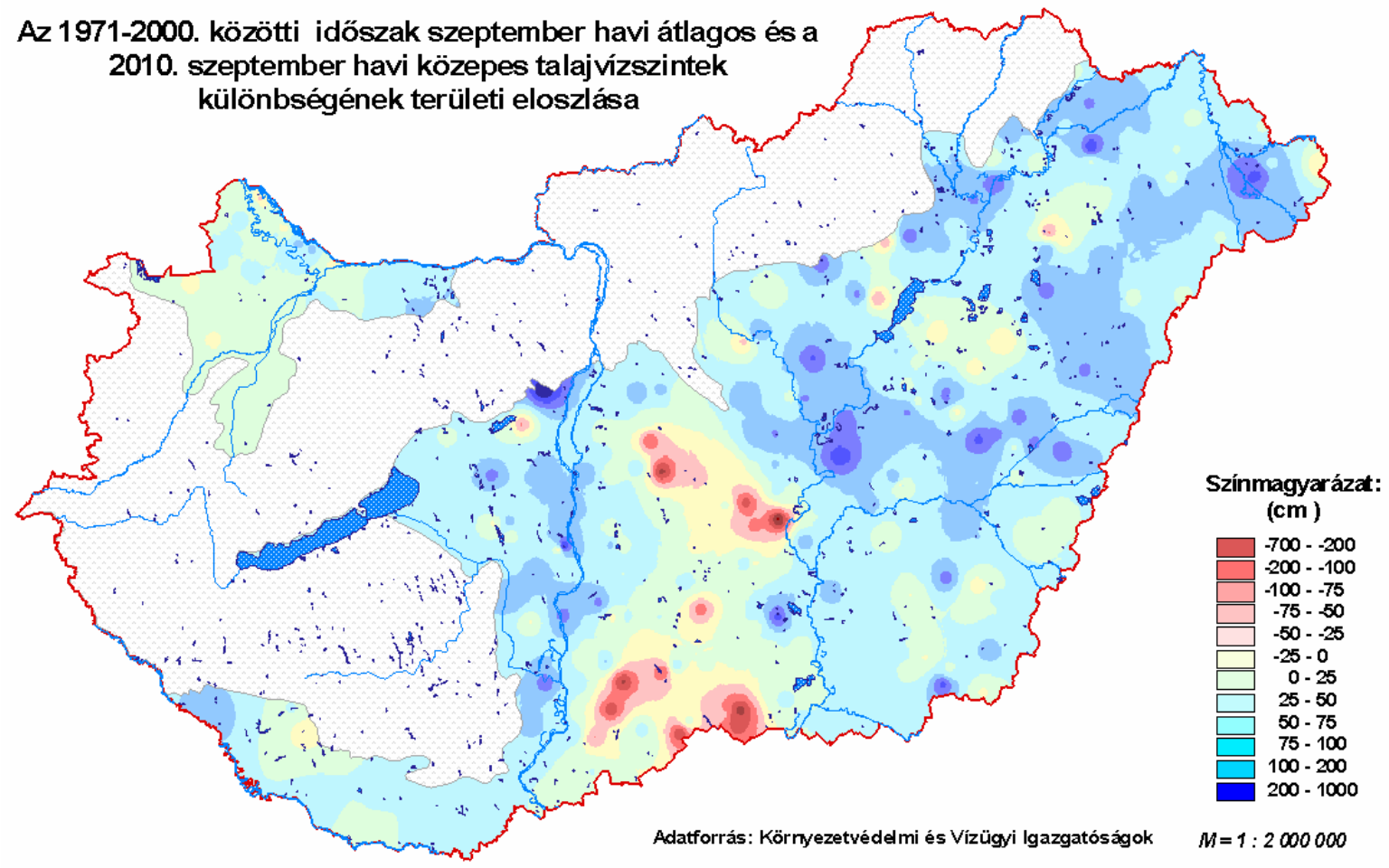

25. ábra. Az 1971-2000. közötti idöszak szeptember havi átlagértékek és a 2010. szeptemberben mért talajvizszintek középértékei különbségének területi eloszlása (Szalai 2010) 


\section{AZ ILLANCS TÁJHASZNÁLAT-VÁLTOZÁSAINAK ÉRTÉKELÉSE}

\subsection{Tájhasználat-változások és a Duna-Tisza köze}

A tájhasználat-változás és maga a (nem megfelelő) tájhasználat napjainkig a biodiverzitást leginkább fenyegető tényező. A történeti földrajzi és tájértékelési szempontú elemzések általában a hosszú távú változásokat követik nyomon (pl. Konkolyné Gyúró 1990, Beluszky 2001, Czinege et al. 2004, Szilassi 2006). A tájmintázat-változás kutatása gyakran természetvédelmi és tájrehabilitációs célokat is szolgálhat (pl. Csorba 1996, Konkolyné Gyúró 1994, Tóth 2004, Lukács et al. 2004). Modern kutatási irányzatnak számít a tájhaszálat-változás modellezése (Veldkamp - Fresco 1996, Verburg et al. 1999), aminek célja a tájváltozás szimulációja a különböző tájhasználatok és azok hajtóerőinek összefüggéseit tapasztalati úton leíró tényezők segítségével (Duray 2009).

A tájhasználat változásait kiváltó okok csak társadalmi-gazdasági-környezeti kontextusban vizsgálhatóak teljes körüen (Turner - Meyer 1994), melyek következményei e rendszerekre pozitív és negatív hatással is lehetnek (Tress et al. 2005). Erre jó példa lehet egy csatornákkal belvízmentesített mélyedés, ami a víz elvezetésével már művelés alá kerülhet. A folyamat eredményeképpen a társadalmi jólét és a gazdasági érdek nyer a biodiverzitással szemben.

Természetföldrajzi adottságai miatt az Alföld hazánk egyik leginkább müvelésbe vont területe, fennmaradt természeti területei ma már döntő részben védettséget élveznek. Duna-Tisza közi viszonylatokban általában tájegység vagy kistáj szintű elemző tanulmányok születettek az elmúlt évtizedekben (Dóka 2009, Kovács 2006, Mucsi-Kovács 2005, Pándi 2006, Somay et al. 2009, Schrett 2005, Török et al. 2006). Bíró (2006) a történeti térképek tájhasználat-változás elemzésén túlmutatóan kidolgozta a történeti térképeken alapuló vegetáció-rekonstruckió módszertanát, és régiós léptékben alkalmazta is azt a Duna-Tisza közére.

A tájhasználat változása itt döntően az emberi gazdálkodás terjedéséhez köthető, melyhez jelentősen hozzájárult a szántó- és erdőgazdálkodás fejlődődése is: a gépesítés, a modern technikák egyre nagyobb területek müvelését tették lehetővé. Ráadásul a múlt század közepi műveléskényszer végképp rányomta a bélyegét az alföldi tájakra. Kérdésként merülhet fel, hogy melyek azok a tájhasználati változások, amelyek a jelentős (akár régiós léptékü) környezeti változásokkal kapcsolatosak? Vajon tényleg befolyásolhatta-e a 4. fejezetben említett erdősítés a Duna-Tisza közi talajvízszint-csökkenését? Vajon a csatornák vízelvezető hatása valóban kevésbé jelentős a vizes területek lecsapolása tekintetében (amelyek akár beszántható területté váltak)? Mennyiben járult hozzá a mủvelt területek expanziója a természetes élőhelyek fragmentációjához? 


\subsection{Felhasznált anyagok és módszerek}

A tájhasználat-változások értékeléséhez az első, második és harmadik katonai térképezés és a Kreybig-féle Átnézetes Talajismereti Térképsorozat megfelelő szelvényeit, az 1950-1960-as évek Gauss-Krueger térképeit, az 1980-as évek topográfiai térképeit, a CORINE Land Cover 1:50.000 (CLC50) adatbázisát, valamint a 2005-ös légifényképezés felvételeit használtam fel. Az adatok digitalizálása és térinformatikai analízise az ArcMap 9.3-as szoftverrel történt. A különböző térképlapok eltérő tájhasználat-kategóriáit közös jelkulcs alá vontam, melynek eredményeként a szántó, a szőlő és gyümölcsös, az erdő, a rét/legelö/parlag valamint a települések (belterületei) kategóriákat különböztettem meg. A történeti térképek mozgó homokbuckái a rét/legelö/parlag kategóriába kerültek, hiszen ezek a jelenségek már a 20. század közepére szinte teljesen eltüntek, de a 18. és 19. században még a nyílt homokpuszta-gyepek mellett a táj fontos és jelentős részét képezték. Az összevonások kritikus pontjai voltak továbbá a vágásterületek (az 1950-es éveket követően), melyeket időszakos jellege miatt az erdő kategóriába soroltam. A Corine Landcover 1:50.000-es méretarányú felszínborítási adatai is ezen analógiák alapján kerületek összevonásra. A kiértékelésekhez a következökben a Marosi - Somogyi-féle kistájkataszterben lévő szűkebb, a dolgozat 4. fejezetében bemutatott módosított tájhatárt használtam. A táj átalakításának mértékét a tájhasználati stabilitáson keresztül vizsgáltam, foltállandósági mátrixot készítve az egyes idősíkok azonos kategóriáinak átfedései alapján. A tájhasználat változása mellett (és ahhoz szorosan kapcsolódva) további antropogén hatásokat is értékeltem. Geomorfológiai elemzésekkel vizsgáltam a kistáj jellemző homokformáit, elemeztem és szemléltettem a planírozások és az infrastruktúra hatásait a tájra.

\subsection{Eredmények}

\subsubsection{Tájhasználat változás értékelése az Illancson (a szükebb lehatárolás alapján)}

A 18. századi források és térképek szerint a Duna-Tisza köze területét többnyire fátlan élőhelyek borították, a fásszárú vegetáció aránya tájszinten mindössze 3,5\% volt. A nyílt homoki vegetációmozaikok 78\%-a a 18. században a Duna-Tisza köze déli részén fordult elö (Bíró 2006). Az Illancs kistájon ekkor még döntően nyílt homokpusztagyepek és mozgó homokbuckák domináltak (együttesen kb. 80\%-ban), jelentősebb kiterjedésű fásszárú vegetáció nem jellemezte a tájat (26. ábra). A jelentős homokmozgások ${ }^{3}$ megfékezése a 19. századra fontos kérdéssé vált (ún. homoksiványok terjedésének meg-

\footnotetext{
3 A népnyelvben is fennmaradtak „Illancs mozgó, füstölgő homokbuckái”
} 
állítása), és elkezdődött a homok fásítása. Megfelelő szakértelem és ismeretanyag hiányában azonban a fásítás nehezen indult, és az 1860-as évekig csak kis területeket érintett (Molnár 2003).

Az Illancson a 19. század végén több uradalom osztozott. A Kalocsai Érsekségé volt a szentistváni (a csávolyi, sükösdi és csanádi határral) és a hajósi (hildi és kélesi határral) uradalom (a római Boncompagni hercegi családé volt a terézhalmi és a felsőterézhalmi uradalom). Az erdőmester Wendl Károly irányításával végezték el a futóhomokos, buckás területek akáccsemetékkel történő beültetését. A korábbi fekete nyárról akácra történő áttérésben szerepe volt Haynald Lajos botanikus akadémikus érseknek, ő rendelte el az erdei fenyővel történő kísérleti telepítéseket is (Nebojszki 2004). A II. katonai felmérés idejére (19. század közepe) már a kistáj 15\%-át borították erdők (27. ábra). A 19. század második felében kisebb lendületet kap az erdősítés (már akáccal is, sikeresen (Molnár 2003)), és az 1800-as évek végére az illancsi erdőállomány eléri a 20\%-ot. A nagyobb, összefüggő erdőfoltok a mai Borota és Császártöltés települések között voltak, a legmagasabb részeket (Ólom-hegy, Kopasz-hegy és környéke) csak kis kiterjedésű erdőfoltok jellemezték. A 20. század közepére az erdőgazdálkodás egyre intenzívebbé vált, és ekkor már nem elsődlegesen a futóhomok megkötése volt a cél. Az 1040/1954. sz. minisztertanácsi határozat az erdőgazdaságokat a mezőgazdasági művelésre alkalmatlan homokterületek fásítására is kötelezte (Molnár 2003). A területen zömmel akácot, illetve fekete és erdei fenyőt ültettek, és a telepítés motorizálásával sokkal jobb hatásfokot érhettek el. Néhol próbálkoztak nyár telepítésével is, azonban a 20. század végi szárazodás a nagy vízigényü fafajták telepítését lehetetlenné tette e kistájban.

A tájhasznosításban tehát az elmúlt két évszázad során egyre inkább dominánssá vált az erdő, mely ma a kistáj közel 60\%-át borítja. Az 1990-es években komoly vita bontakozott ki az erdészet és a vízügy között, hogy vajon milyen mértékủ az erdők talajvízelszívó hatása, és ez mennyiben járul hozzá a talajvízszint-süllyedéshez. A vita a VITUKI kutatásait elemző Major és Neppel (1988) cikke alapján indult el, akik a Duna-Tisza közi folyamatos talajvízszint-csökkenés kiváltó okai között jelentősebbnek ítélik a rétegvízkitermelés hatását és az erdők vízfelhasználását a klimatikus faktorokéhoz képest. Az erdészet (Szofridt 1990) elismerte, hogy igaz az a tény, hogy az erdők általában több vizet igényelnek, mint a mezőgazdasági kultúrák és az intercepciós veszteség is nagyobb az erdők esetén, azonban felhívta a figyelmet egyéb tényezőkre is. Egyrészt az erdőnek van párolgáscsökkentő hatása is (mikroklíma), valamint a természetes erdőket alkotó kocsányos tölgyek és fehérnyarasok helyett - melyek a megváltozott viszonyok között nem voltak 
képesek vízigényüket kielégíteni - föként fenyveseket telepítettek. Ezek éves vízigénye sokkal kisebb az előbb említettekhez képest. Megállapítja, hogy a talajvíz-csökkenésben a szárazságtűrő fenyvesek nem játszanak jelentős szerepet, illetve kiemeli, hogy ezen fafajok döntően futóhomokos váztalajokon, gyengén humuszos homok talajtípusokon helyezkednek el, a gyökérzetük a talajvízszinttel nincs kapcsolatban. Későbbi kutatások a vízhiány okai között az erdők és a földhasználat szerepét 10\%-nak ítélték (Pálfai 1994a).

A 18. századi források alapján az Illancs $80 \%$-ánál jelentősebb területet borítottak nyílt homoki gyepek (27. ábra). Mủvelésbe vonásuk már a 18. században megkezdődött az Illancson. A legelők és rétek kiterjedése az 1800-as évek közepére a felére esett vissza, majd az 1900-as években tovább csökkent (38\%) a nagy szőlöültetvények és gyümölcsösök, valamint az egyre terjeszkedő szántók mellett (27. ábra). Habár a tájban jelentősen csökkent a nyílt homokpuszta gyepek dominálta buckások területe, a gyepek nyíltsága nem változott az 1950-es évekig, fő használati módja a kisparaszti juhlegeltetés maradt (Kun 1998). A kisparaszti legeltető állattartás csökkenésével és az egyre jelentősebb kiterjedésű erdök szélfogó hatása következtében viszont később a homoki gyepek fokozatos záródását lehetett megfigyelni. A területi kiterjedésének minimumát e tájhasználati kategória a 20 század közepén érte el (5,5\%). Később, amikor a nagytáblás müvelés időszaka hanyatlani kezdett, a felhagyott területek száma szaporodott, így a regenerálódó parlagokkal együtt a homoki gyepek összkiterjedése ismét jelentősebb, közel 20\% körüli értéket ért el. Kiterjedésük az elmúlt 20-30 évben lényegesen nem változott. A 2000-es évek elején megfigyelhető kismértékü (3\%) csökkenő tendencia, mely a buckavonulatok közötti mélyedések szárazodásával mủvelhetővé váló talajok beszántását jelezheti, főleg a terület DK-i peremén a Bácskai löszhát irányában. Összességében elmondható tehát, hogy az egykori természetes vegetáció szinte teljes egésze az elmúlt két évszázad során müvelés alá került. Máig fennmaradt természetes, bolygatatlan nyílt homokpuszta gyep szinte csak az immáron védett, Hajósi Homokpuszta Természetvédelmi Területen maradt fenn. 

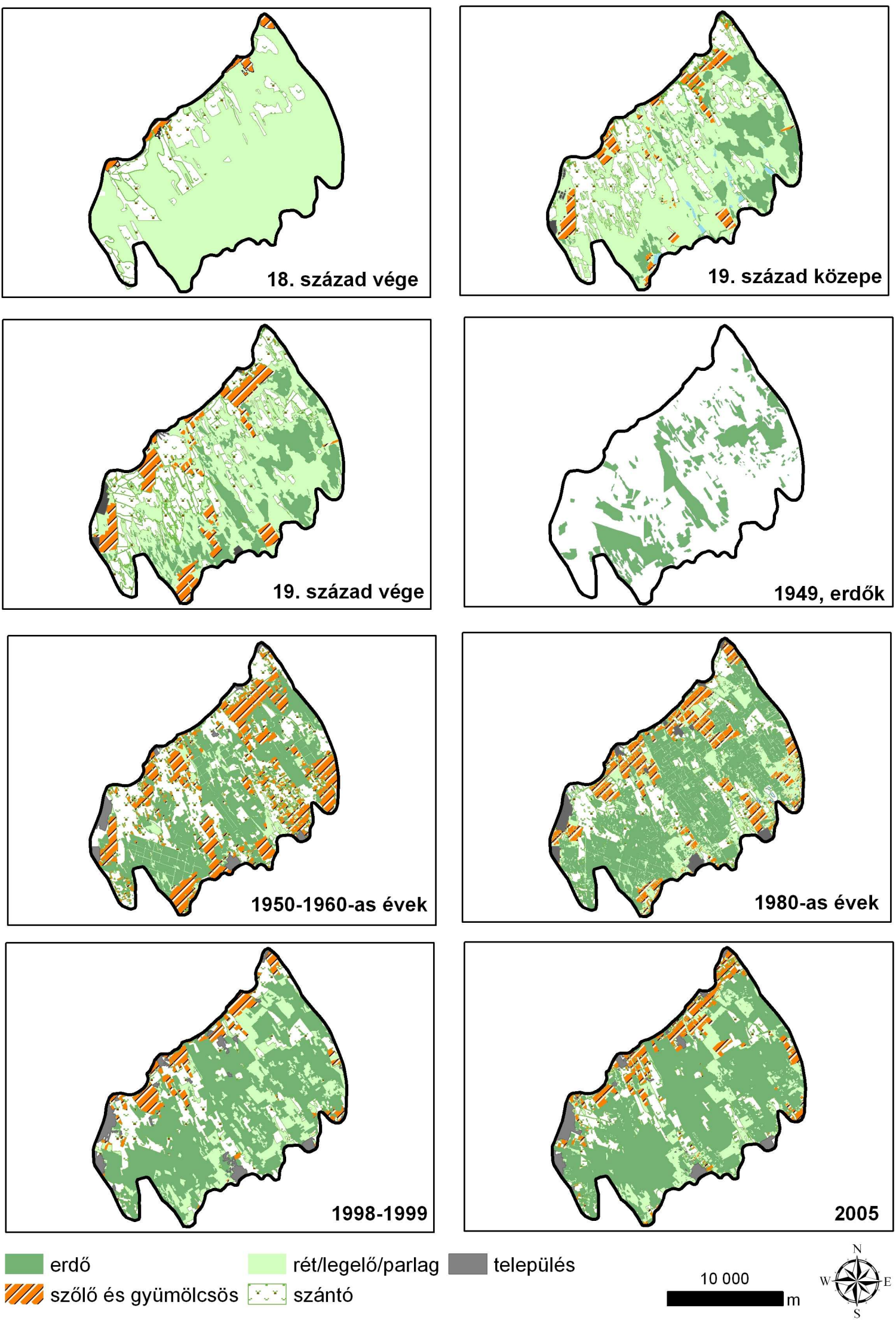

26. ábra. Illancs tájhasználat-változása az elmúlt két évszázadban (az I., II., III. katonai térképezés, a Kreybig-féle Átnézetes Talajismereti térképsorozat, a Gauss-Krueger térképek, a Corine 50, topográfiai térképek, valamint 2005-ös légifotók felhasználásával)) 

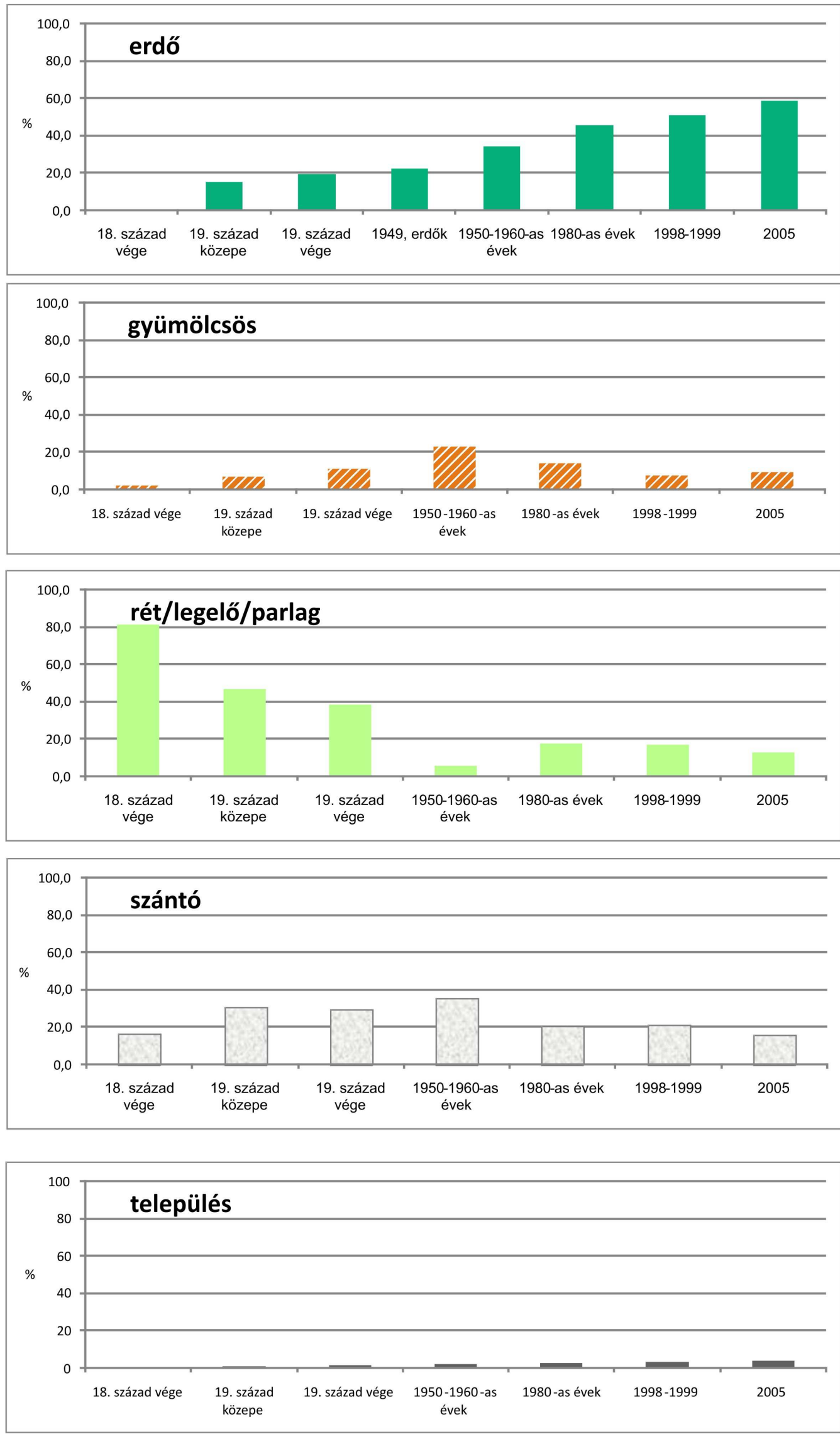

27. ábra. A tájhasználat változása az elmúlt két évszázadban, a kistáj teljes területéhez viszonyítva, százalékban 
A lösszel borított felszíneken a Kecel-Bajai-magaspart mentén már a 18. században is voltak jelentősebb kiterjedésű szántók (26. ábra). Később a második és a harmadik katonai térképezés szelvényein arányuk jelentősen megnő, számos helyen még a homokbuckák közötti mélyedéseket is beszántották. Ennek oka lehetett azok jobb termőtalaja, jobb vízgazdálkodása, vagy éppen a gazdálkodók kényszere a megélhetés miatt. A 20. század közepének szántómaximuma (35\%) szorosan kötődik a termelő szövetkezetek és a nagytáblás mủvelés időszakához. A század további részében az erdőtelepítések okozzák a szántók kiterjedésének kis mértékü csökkenését. Az 1990-es évek végi kárpótlások során sokan jutottak homokterületekhez, ahol szántóművelésbe fogtak, amit e tájhasználati kategória csekély emelkedése is alátámaszt, azonban a 21. század elején ismét csökkenő tendencia mutatkozott, melyben a szárazodás hatása is szerepet játszhatott. A szántók a mai napig számottevők a kistájon, különösen a lösz, a homokos lösz illetve a löszös homok dominálta területeken a Kecel-Bajaimagaspart mentén.

Szölők és gyümölcsösök már a 18. század végén is voltak a kistájon, legnagyobb részben annak ÉNy-i peremterületein. Az 1800-as években egyre bővült a kiterjedésük, és század végére a terület délkeleti peremén is (Rém, Borota) újabb telepítések jelentek meg. A 19. század utolsó harmadában bekövetkező filoxéra járványt követően a szőlők a magasabb fekvésű homokterületek irányában terjeszkedtek. E tájhasználati kategória területi kiterjedésének maximumát a 20. század közepén érte el (27. ábra). Az 1990-es éveket a művelésfelhagyás jellemzi. Ennek okai a termelő szövetkezetek felbomlásában, a magyar társadalom és gazdaság átalakulásában, a terület elnéptelenedésében és a 20. század végétől egyre fokozódó vízhiányban keresendők. A lesüllyedt talajvízszint következtében a gyümölcsösök, a szőlők és az erdők is károsodnak: csökkent a betegségekkel, légköri szennyezettséggel és fagygyal szembeni ellenállóságuk (Harmati 1994). A 21. századi csekély mértékű emelkedés a terület újranépesedésével és a (homoki) borkultúra újbóli felélénkülésével köthető össze.

Az ÉNy-i peremterületek népessége már a 18. században is jelentős volt, viszont a DK-i régió benépesedése csak a 19-20. századra tehető. A második katonai térképezés szelvényein például Borota és Rém még csak „Puszta Borota” és „Puszta Rém” néven szerepelt. A települések területi növekedése a 20. század folyamán töretlen volt, habár az 1980-as években a csatornázottság, az áramellátás és a vízhiány miatt a magasabb részek buckásaira telepített tanyák elnéptelenedtek. A lakosság növekvő vízigénye és a termeléshez szükséges öntözővíz szükséglete szintén hozzájárult a vízhiány kialakulásához (Pálfai 1994).

Mára a bolygatatlan természeti területekből rendkívül kevés maradt fenn, a kistáj mindössze 1,5 \%-án. Három természeti terület őrzi az egykori természetes élővilág nyomait 
(28. ábra), melyek közül a legnagyobb, a Hajósi Homokpuszta Természetvédelmi Terület (1), védettséget élvez, és döntően száraz homoki élöhelyek borítják. A Borota település környezetében fellelhető természetes gyepek (2) a korábbi vízborításuknak (és feltehetően szikes talajtulajdonságainak) köszönhetik a mai napig fennmaradásukat. A Rémtől nyugatra fekvő természetes folt (3) a Kopasz-hegyen található. A változatlan tájhasznosítású foltok közé a Kecel-Bajai-magaspart mentén húzódó szántók és szőlök sorolódnak még, melyek jó minőségü talajaiknak köszönhetik fennmaradásukat.

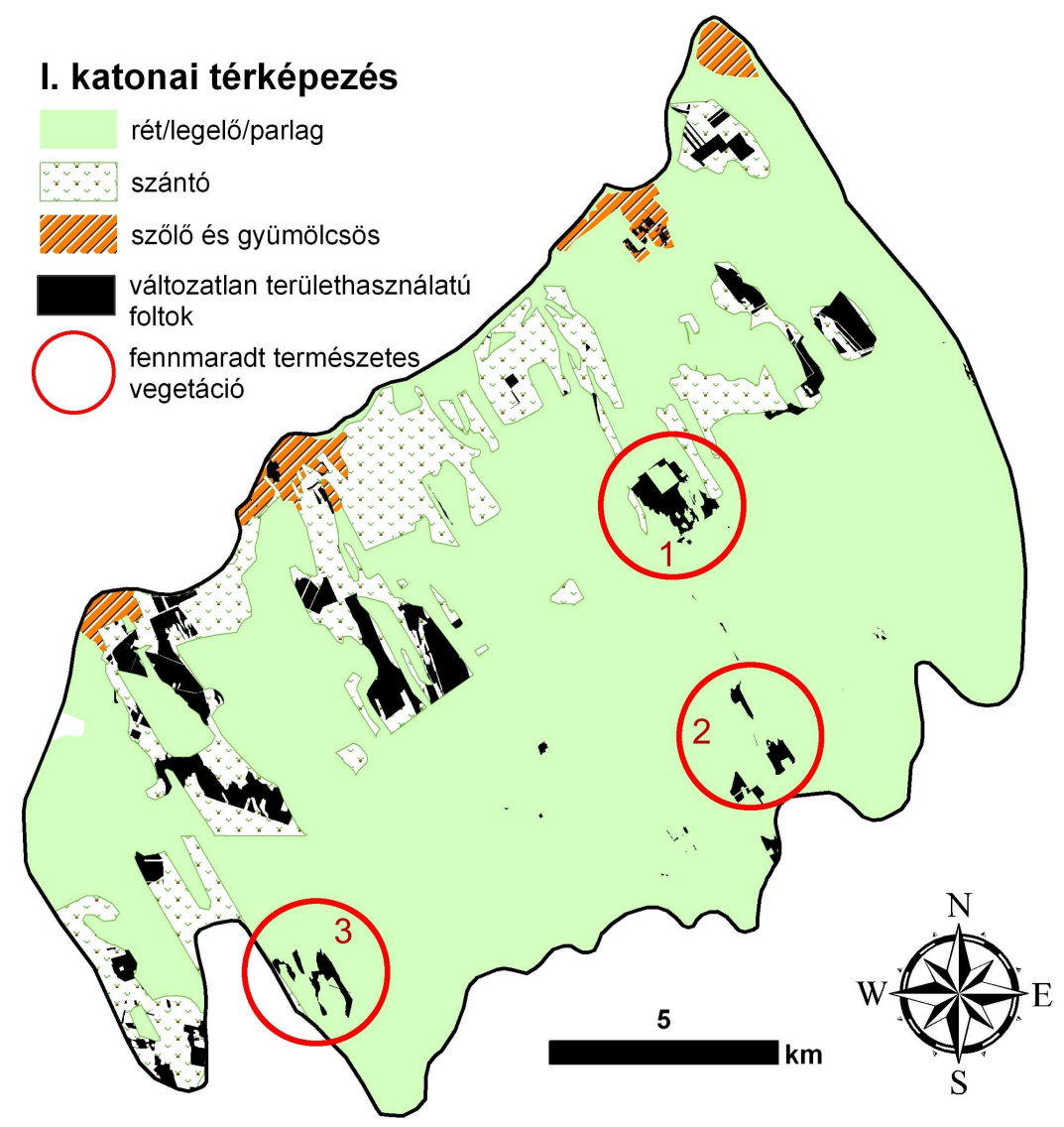

28. ábra. Az Illancs 1800-as évek vége óta fennmaradt „természetes” vegetációja (bolygatatlan területei), illetve az 1800-as évek óta változatlan területhasználatú területei 2005-ben 1. Hajósi Homokpuszta Természetvédelmi Terület

2. Borotai legelö

3. Kopasz-hegy

Illancs területének 90\%-a került az elmúlt kétszáz év alatt (erdőgazdasági-, mezőgazdasági-) mủvelés alá (1. táblázat), összességében a kistáj 98,5\%-a vált így bolygatottá. A tájátalakítás már a 19. század közepén megkezdődött, maximumát 20. század közepén érte el, amikor a tájhasznosítás a 18. század végi állapotokhoz már csak 10 \%-ban hasonlított (föleg a magaspartot övező löszperemen). Összehasonlítva a mai állapotokat az 1800-as évek végéhez képest, ma az Illancs területének 19\%-án találunk egyező hasznosítású foltokat, melyek jelentős része - az előbb említett területeken felül - szőlő és szántóművelésből regenerálódó parlag. 
1. táblázat. Az Illancs területhasználat-foltjaiból számított foltállandósági mátrix a tájhasználati stabilitás megállapítására

\begin{tabular}{|c|c|c|c|c|c|c|c|}
\hline Foltállandóság & $\begin{array}{l}\text { 18. szá- } \\
\text { zad vége }\end{array}$ & $\begin{array}{l}\text { 19. szá- } \\
\text { zad kö- } \\
\text { zepe }\end{array}$ & $\begin{array}{l}\text { 19. század } \\
\text { vége }\end{array}$ & $\begin{array}{c}1950- \\
1960-a s \\
\text { évek }\end{array}$ & $\begin{array}{l}\text { 1980-as } \\
\text { évek }\end{array}$ & $\begin{array}{l}1998- \\
1999\end{array}$ & 2005 \\
\hline 18. század vége & $\mathrm{X}$ & $54,5 \%$ & $48 \%$ & $10 \%$ & $23 \%$ & $25 \%$ & $19 \%$ \\
\hline $\begin{array}{l}\text { 19. század kö- } \\
\text { zepe }\end{array}$ & & $X$ & $65,5 \%$ & $36,5 \%$ & $33 \%$ & $35 \%$ & $31,5 \%$ \\
\hline 19. század vége & & & $\mathrm{X}$ & $45,3 \%$ & $36,5 \%$ & $37 \%$ & $35 \%$ \\
\hline $\begin{array}{l}\text { 1950-1960-as } \\
\text { évek }\end{array}$ & & & & $X$ & $56,5 \%$ & $52,5 \%$ & $51 \%$ \\
\hline 1980-as évek & & & & & $\mathrm{X}$ & $69 \%$ & $69,5 \%$ \\
\hline 1998-1999 & & & & & & $\mathrm{X}$ & $80 \%$ \\
\hline 2005 & & & & & & & $\mathrm{X}$ \\
\hline
\end{tabular}

Megjegyzés: a szürkével jelölt számított értékek az alapadat pontosságának 50-200 m (I. katonai térkép, II. katonai térkép) hibáját hordozzák

Kérdésként merülhet fel, hogy mennyire tekinthetjük természetes állapotot tükröző forrásnak az I. katonai térkép által bemutatottakat, hiszen a török hódoltság után elnéptelenedett, pusztásodott, de előtte évezredek óta lakott tájról nem tudjuk (nincs megfelelő térképi és egyéb adatforrás), hogy milyen volt. Nem ismerjük például, hogy mennyi parlag területe volt, hol voltak a török hódoltság előtti erdők, cserjések és szántóterületek a Duna-Tisza közén (Bíró 2008). A fentiek alapján azonban látható, hogy az elmúlt évszázadok Illancsát a folyamatos kultúrterületté való átalakulás jellemezte, melynek eredményeképpen az eredeti természetes vegetáció (nyílt homoki gyepek, galagonyás nyarasok) csak kis kiterjedésben, fragmentálva maradt meg. A müvelt területek felhagyása után visszagyepesedő parlagok száma jelentős, invazív fajokkal való fertőzöttsége nagy (Asclepias Syriaca, Robinia pseudoacacia), annak ellenére, hogy megfelelő kezeléssel (pl. juhlegeltetés Borotán) a parlagok természetességi állapota javítható. A selyemkóró terjedésében nagy szerep jut ma a méhészeknek, akik az utóbbi évtizedekben jelentek meg a homokbuckásokon, a telepített akácerdők és az özönnövényként terjedő selyemkóró jó mézelő tulajdonságai miatt.

\subsubsection{Tájhasználat-változás és a tájhatár összefüggései}

A 4. fejezetben tárgyalt tájhatárok kérdését érdemes megvizsgálni a tájhasználat tükrében is. Az Illancs tágabb lehatárolása szerint egészen a Kecel-Kunfehértó vonalig húzódik a kistáj határa. A Császártöltés-Jánoshalma vonalon elválasztva két részre a kistájat, a rémiborotai, illetve a kéleshalmi homokbuckák tájhasználata külön-külön értékelhető (29. ábra) 


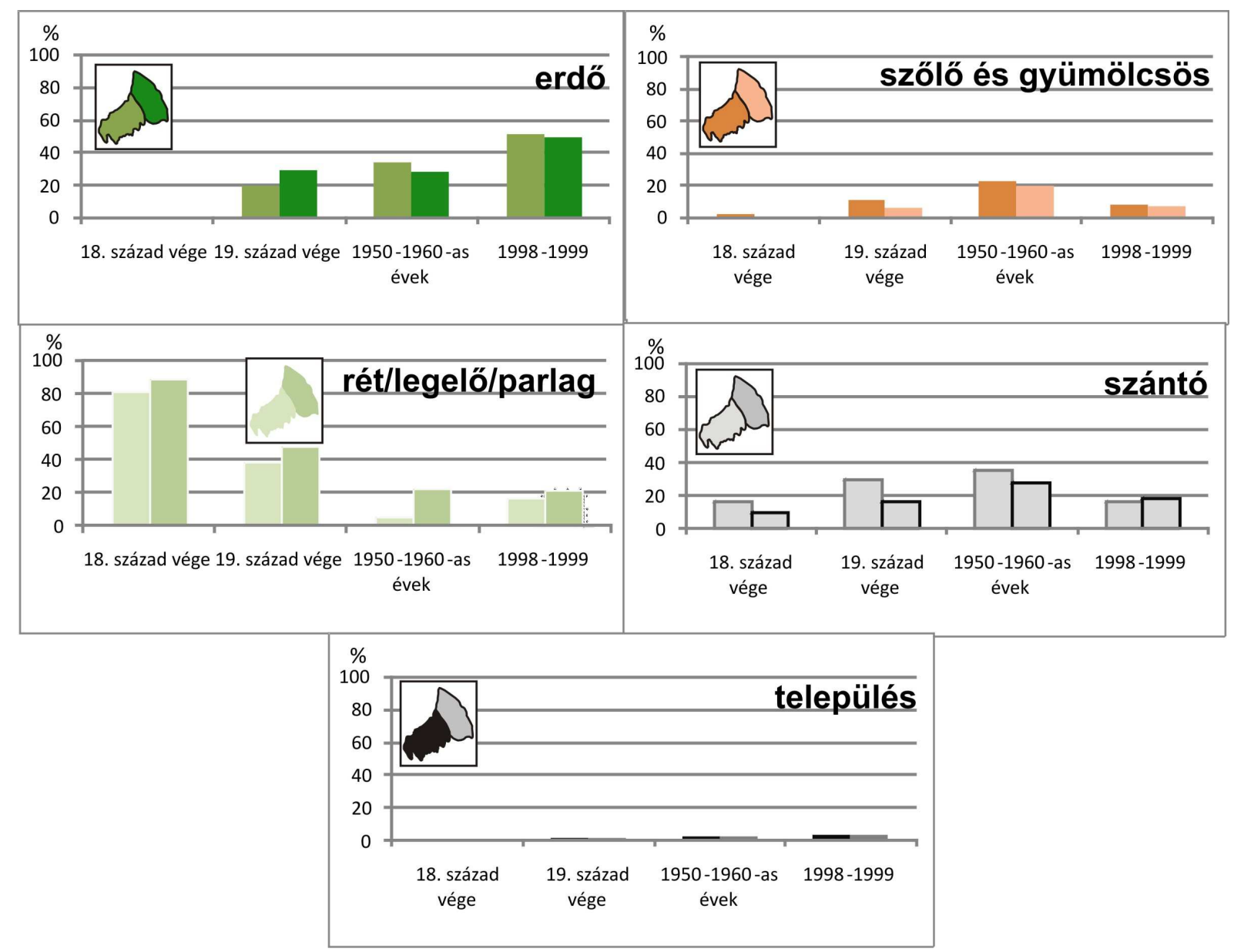

29. ábra. A tájhasználat-változás összehasonlítása a két vizsgált kistájrészletben

A két kistájrészlet tájhasználata hasonló képet mutatott a 18. század végén. A homokbuckákat homoki gyepek borították (melyek a rét/legelő/paralag közös tájhasználati kategóriába kerültek), jelentősebb erdőfoltok nem voltak. Bíró (2006) a Duna-Tisza köze 18. századi tájtípusai és lehetséges élőhelyei elemzésében a délnyugati részt viszont elkülöníti az északkeletitől. Az előbbieket a „magas, meredek homokbuckák, nyílt gyepekkel” (nyílt homoki gyepek, mozgó homokfelszín, nyílt homoki sztyepprétek, buckaközök élőhelyei), míg az utóbbiakat a „magas buckák, feltételezhetően zárt gyepekkel” (homoki sztyepprétek, nyílt homoki gyepek, buckaközi élöhelyei) kategóriába sorolta. A rét/legelő/parlag területek aránya ebben az időben jelentősen nem különbözött a két vizsgált területen. Az erdősítés az ésszakkeleti rész homokbuckáin a 19. században valamivel sikeresebben zajlott (melyet az erdőfoltok kiterjedésének különbségei mutatnak), valamint a 20. századra a délnyugati részhez hasonlóan az erdő átvette a tájhasznosításban az uralkodó szerepet. A müvelt területek (szőlö és gyümölcsös, szántó) növekedése, majd visszaesése hasonló ütemben zajlott a két területen, azonban kiterjedésük a Kéleshalma felé eső 
részen mindig a délnyugati alatt maradt. A települések növekedése mindkét részen megfigyelhető, viszont számuk és kiterjedésük a délnyugati oldalon jelentősebb volt.

A kistáj tájtípusainak különbségeire (a magaspart mentén) már korábbi adatforrások is utaltak (Rónai 1985, Jakucs et al. 1989, Várallyay 1980, 4. melléklet). Az eltérő tájtípusokat jól tükrözheti a tájhasználat időbeli alakulása is, melynek vizsgálatához elkülönítésre került egy jobb talajadottságokkal rendelkező kistájrészlet a magaspart mentén. E kistájrészletek tájhasznosítása különböző képet mutat az elmúlt évszázadokat tekintve (30. ábra).
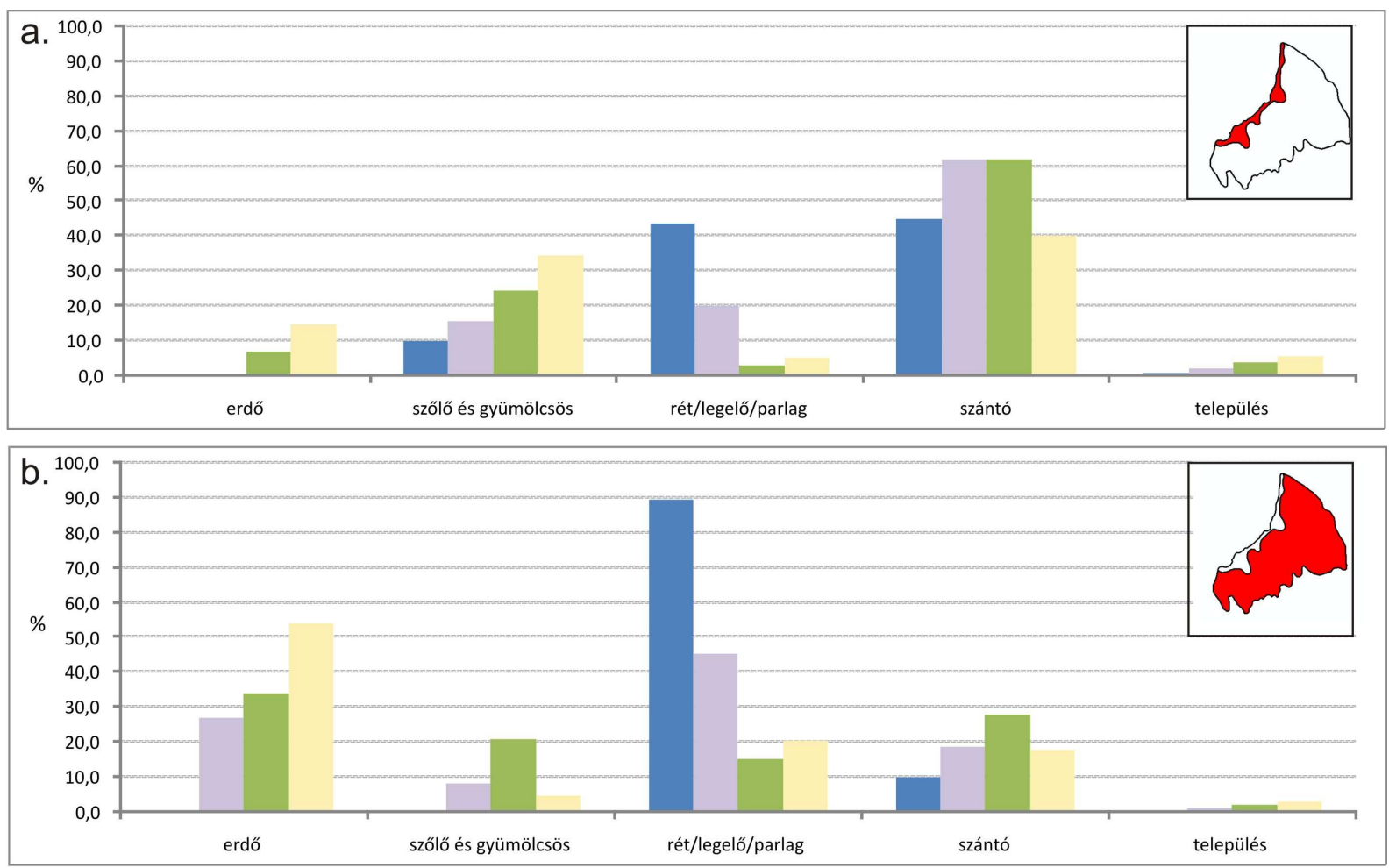

18. század vége

19. század vége

20. század közepe (1950-1960)

20. század vége

30. ábra. A tájhasználat változásának összehasonlítása a 18. századtól a 20. század végéig az eltérö adottságú terïleteken

a. az északnyugati löszperemen

b. a homokbuckákon

A Kecel-Bajai-magaspart - lösz, löszös homok és néhol homokos lösz borította területeit már több, mint 50\%-ban borították művelt területek (szőlők és szántók) a 18. században. Ez az érték a 19. században 70\%, a 20. században pedig 80\% fölé emelkedett. A területen a természetes növénytakaró beszántásával a 20. századra alig maradtak gyepek, ezek döntően a löszvölgyekben ma már védett területen találhatóak (pl. Érsekhalma- Nemesnádudvari löszvölgyek). A 20. század végi müvelés-felhagyás és a parlagterületek növekedése ezt a területet nem jellemzi. Ezzel szemben a homokterületeken a 18. században 90\%-os volt a természetes, fátlan élőhelyek borítása. Domináns folyamatként az erdők területének növekedése emelendő ki az elmúlt két évszázad folyamán. A homokterületeken is 
nőtt a szőlö és gyümölcsös, valamint a szántók területi kiterjedése, melyben a filoxérajárvány és a betelepítések is szerepet játszhattak. A homoki települések növekedése sokkal lassabb és kisebb mértékủ volt az elmúlt két évszázad során, mint a jó termőtalajú, magaspart mellett húzódó zónában.

\subsubsection{Antropogén környezet-átalakítások az Illancson}

Az uralkodó ÉNy-DK irányú szelek felszínformáló hatására jellegzetes futóhomokformák jellemzik a kistájat (31. ábra). Parabolabuckák (az Illancs déli részén hajtűszerü parabolák, 5. melléklet), garmadabuckák, szélbarázdák és maradékgerincek dominálják a felszínt.
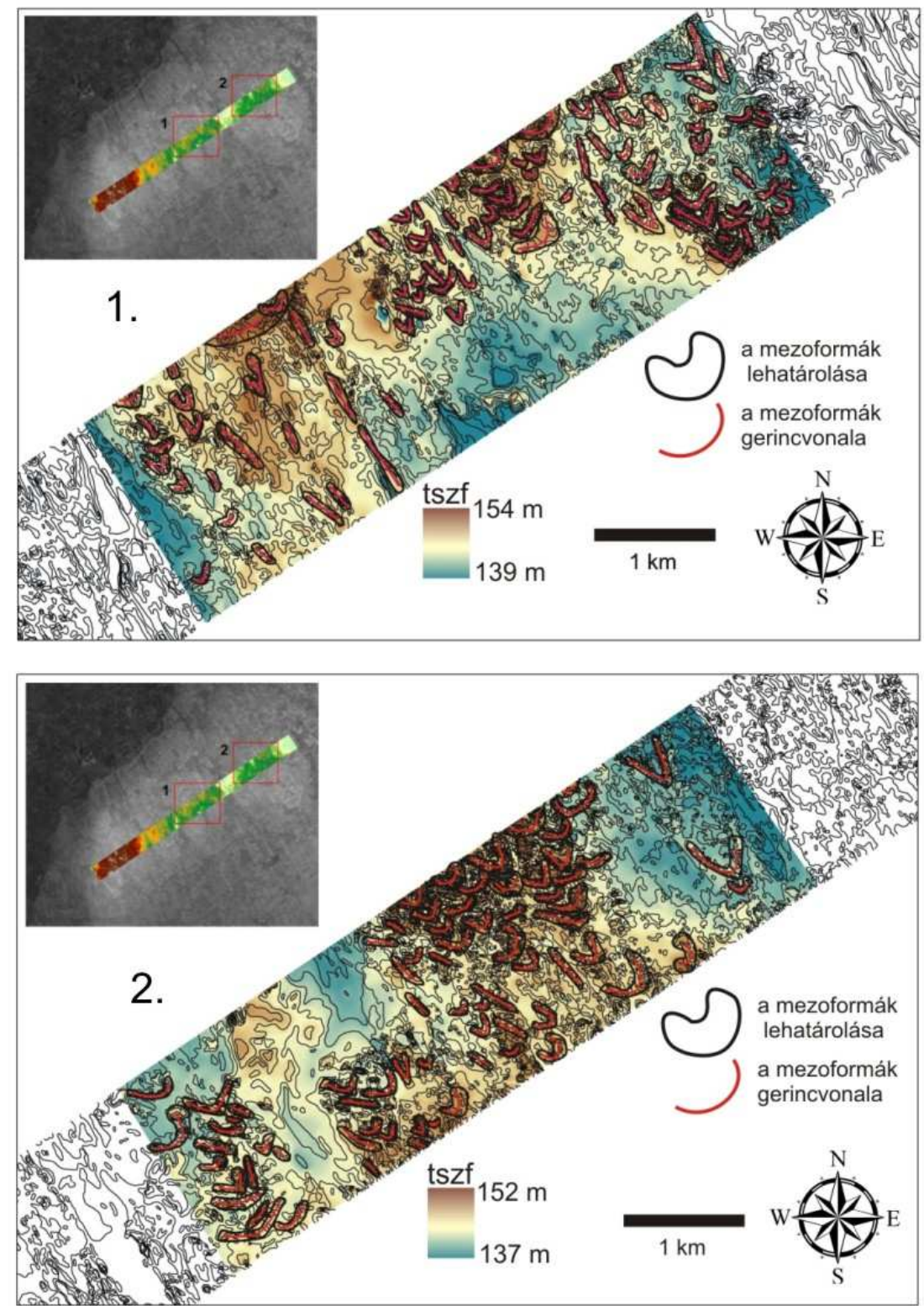

31. ábra. Geomorfológiai térkép az Illancson

1. Szentkata (Antallapos); 2. Kéleshalom, Terézhalom 
Az akkumulációs homokmezőben a garmadák összetorlódása is megfigyelhető. A homokformák különbségeit a különböző szélirány, szélerősség és a felszín növényzettel való fedettsége befolyásolta. A 31. ábrán vizsgált két kivágat Illancsnak abban a két „kistáj-részletében" készült, melyek a tájhatár-dilemmában már említésre kerültek a 4. fejezetben. Jelenetős különbség a geomorfológiai formák alakját, méretét, irányultságát tekintve nem mutatható ki.

A népnyelv a pozitív homokformáknak a „hegy” és a „halom” elnevezést adta (32. ábra). Megállapítható, hogy a kistáj délnyugati részén - melyek Illancs legmagasabb tengerszint feletti magasságon fekvő területei - csak „hegy” elnevezést találunk. „Halmok” a kistáj északkeleti (vitás) kistájrészletében vannak (Kéleshalom, Terézhalom).

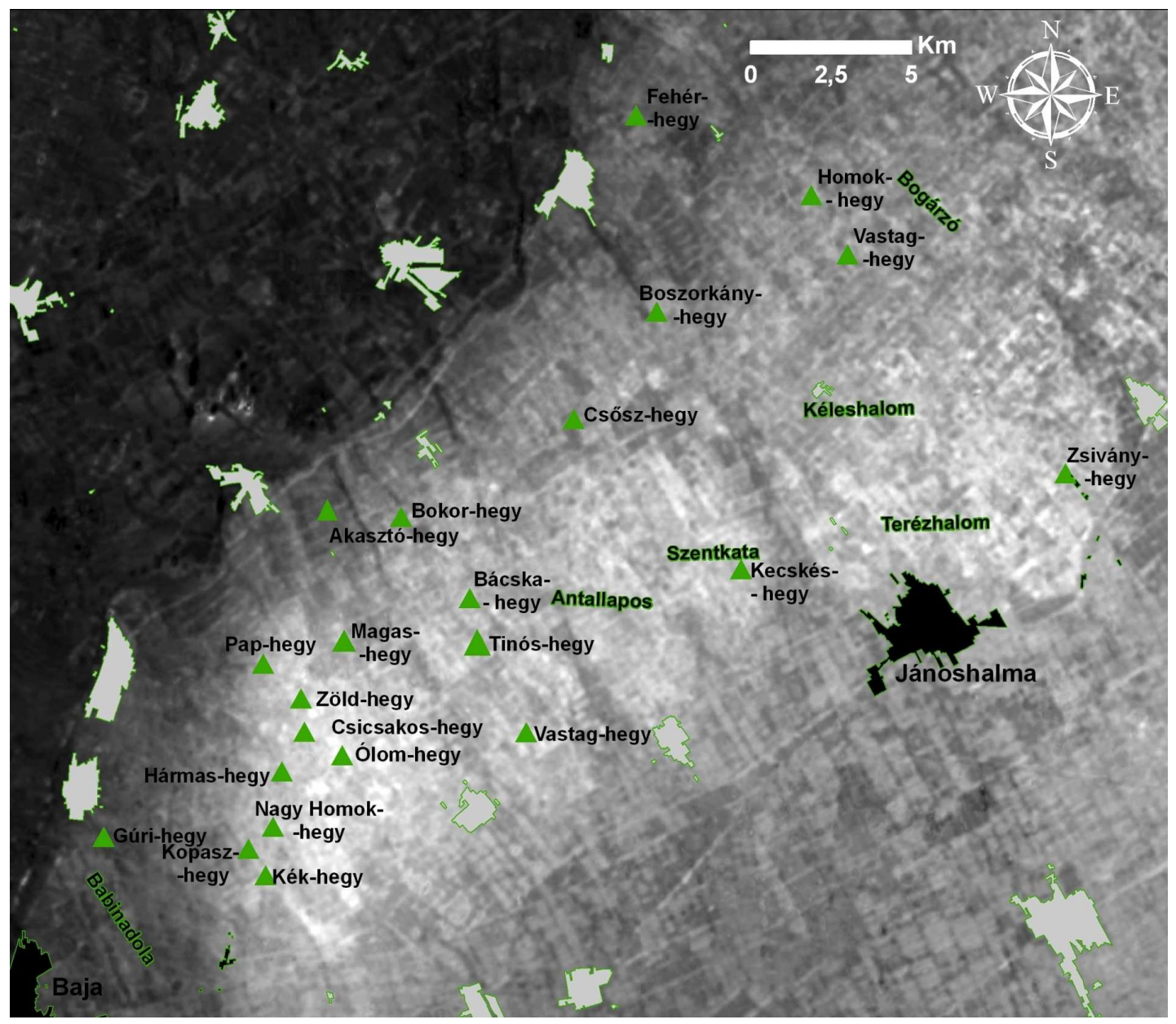

32. ábra. Az Illancs ,hegyei” és „,halmai”

Az 1900-as évek mező- és erdőgazdálkodása jelentős területeken semmisítette meg a jellegzetes homokformákat. Egyrészről a területre korábban betelepített kisparaszti gazdálkodáshoz igyekeztek minden talpalatnyi földet megmüvelni, így egy pár hektáros kiskerthez is egyengettek el buckákat. A nagyüzemi termelés érdekében pedig később motorizált eszközökkel akár több hektárnyi összefüggő területet is elmunkáltak, különösen az 
1960-as éveket követően. Csak a délkeleti határral párhuzamosan 2 km-es sávban vizsgálva a szintvonalak alapján készített lejtőszög-térkép a terület 25\%-án mutatott jelentős kiterjedésű, közel szabályos foltokban a környező területekhez képest eltéréseket, ahol a lejtőszög értékei csupán 0 és $1^{\circ}$ között változtak (33 ábra).

a.
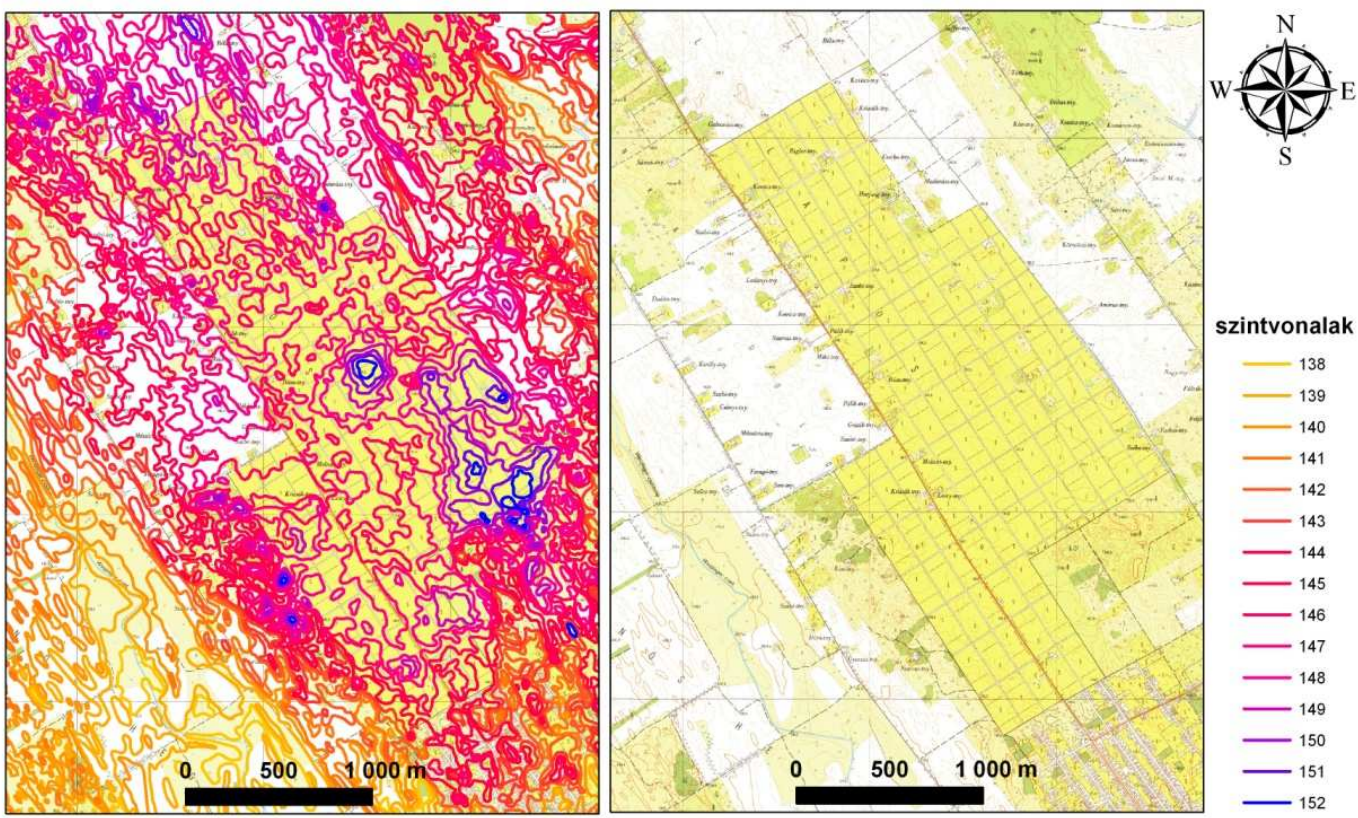

b.

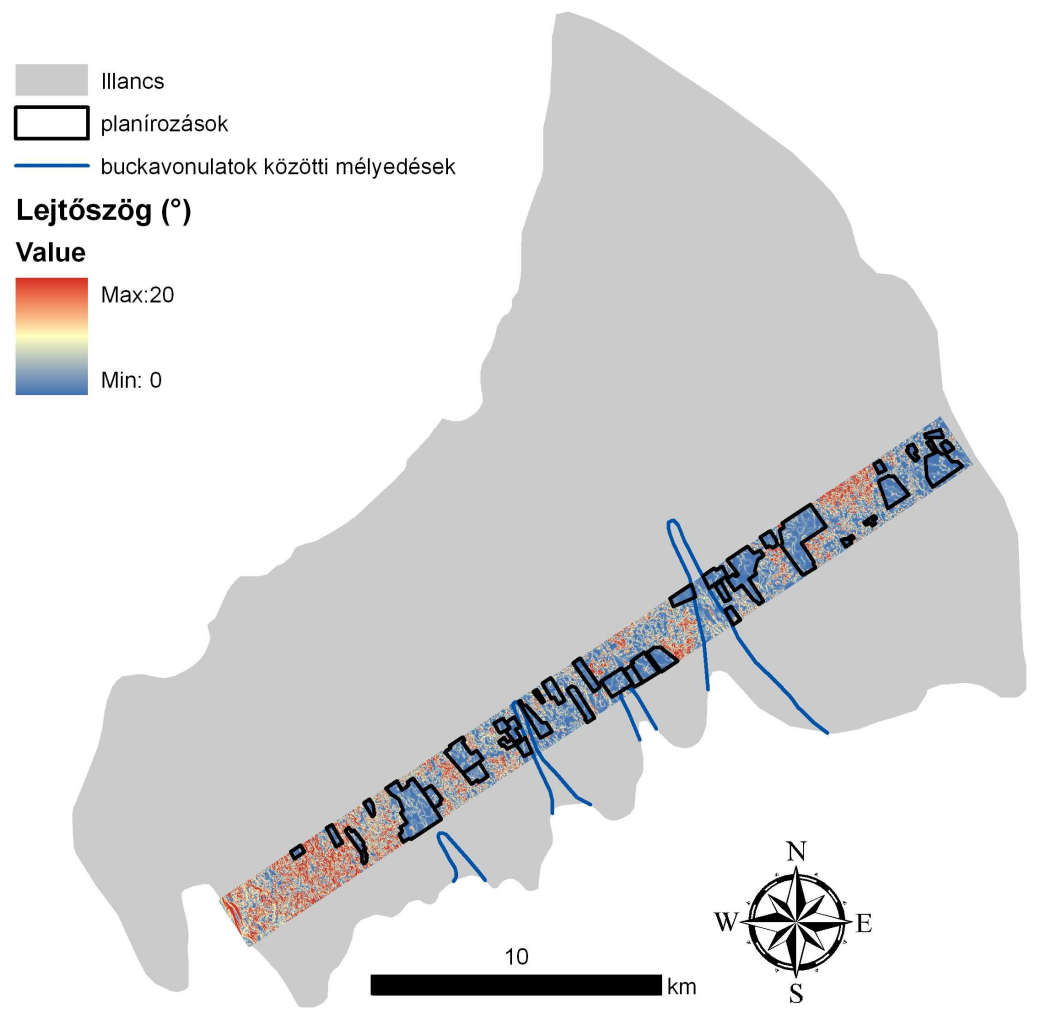

33. ábra. A planírozások nyomai az Illancson

a. A planírozások szemléletetése borotai szölöültetvények példáján

(A szintvonalak sürüsége egyértelmüen kirajzolja a jobb oldalon is látható szőlő-művelés határait) b. A planírozások nyomainak vizsgálata egy $2 \mathrm{~km}$ széles illancsi szelvényben 
Az 1900-as évek közepén volt jellemző a buckások katonai használata lőtérként és gyakorlótérként (Molnár 2003). A harci járművek intenzív taposása és a földmunkák (pl. lövészárkok), vagy a rendszeres kisebb-nagyobb tüzek sok helyen hozzájárultak a természetes vegetáció degradálódásához. De a katonai területként való használat eredményeként akár háborítatlan gyepfoltok is megmaradhattak itt. Az Illancs védett területe, a Hajósi Homokpuszta Természetvédelmi Terület a mai napig őrzi e tevékenységek nyomait (34. ábra).

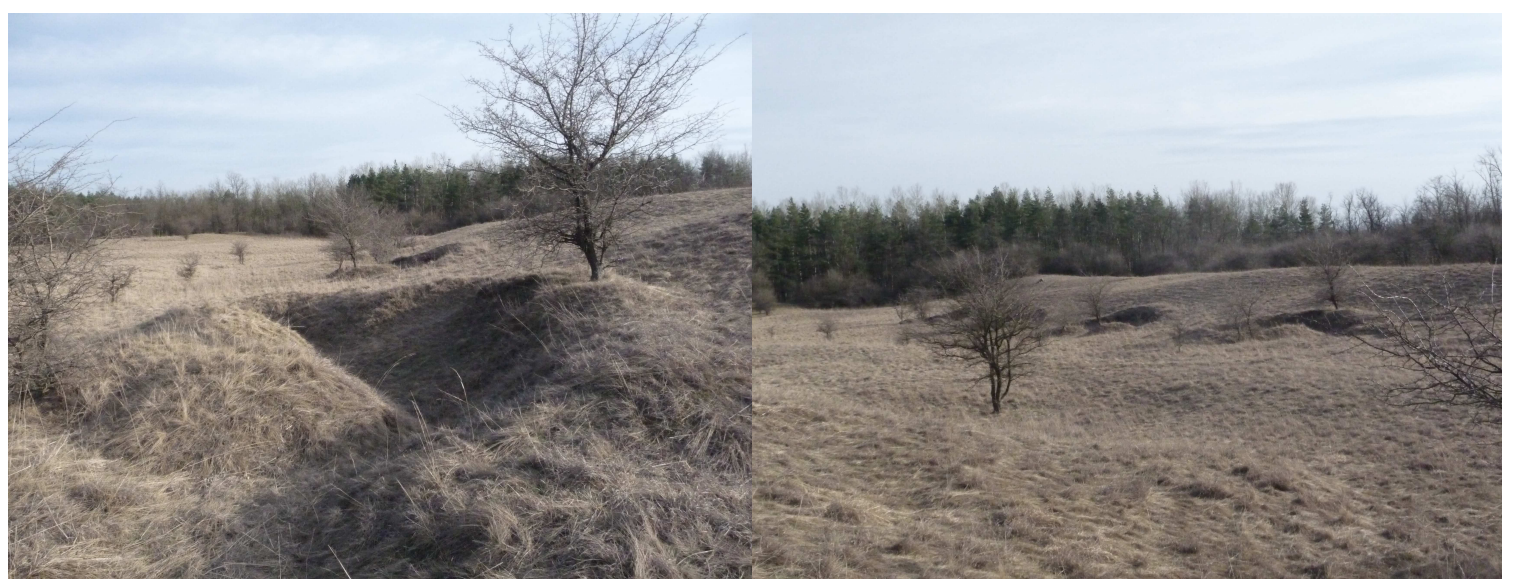

34. ábra. Légvédelmi ütegállások a Hajósi Homokpuszta Természeti Területen

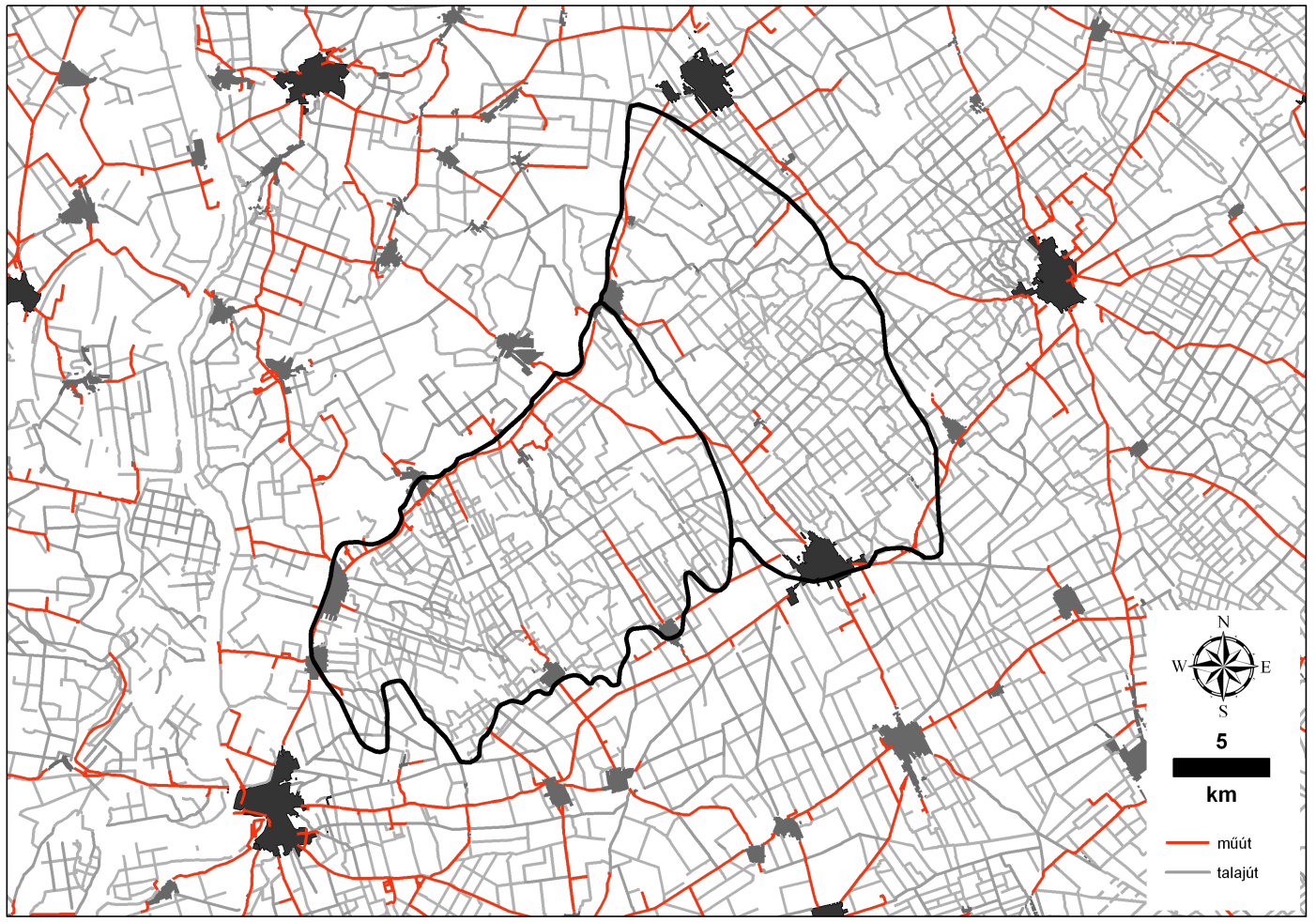

35. ábra. Az Illancs és a környezö területek úthálózata 
A természeti rendszerek müködését fenyegető emberi hatások közül a közlekedési infrastruktúra is jelentős zavaró tényező (Csorba 2005). Az Illancs úthálózata a környező kistájakhoz képest sürű (35. ábra), azonban aszfaltozott utak (melyeknek a legjelentősebb hatása lehetne) leginkább a kistáj peremén találhatóak. Ezek közül legnagyobb forgalmú az 54-es út, amely a Kecel-Bajai magaspart mentén húzódó településeket köti össze. Döntően a földutak alkotnak sủrű hálózatot a buckavidékeken. A fennmaradt természeti területek tekintetében viszont a földutak zavaró tényezőnek bizonyulhatnak. A Hajósi Homokpuszta Természeti Területen a gépjárművek hatására bekövetkező erózió is megfigyelhető (36. ábra). A növényzet a taposás hatására eltủnt, szabaddá vált a homokfelszín. A homokot a szél könnyen mozgásba hozta, aminek hatására az út már néhol másfél métert vágódott a homokbuckába. Ennek következtében a járhatatlanná váló út helyett újabb nyomvonal került kialakításra.

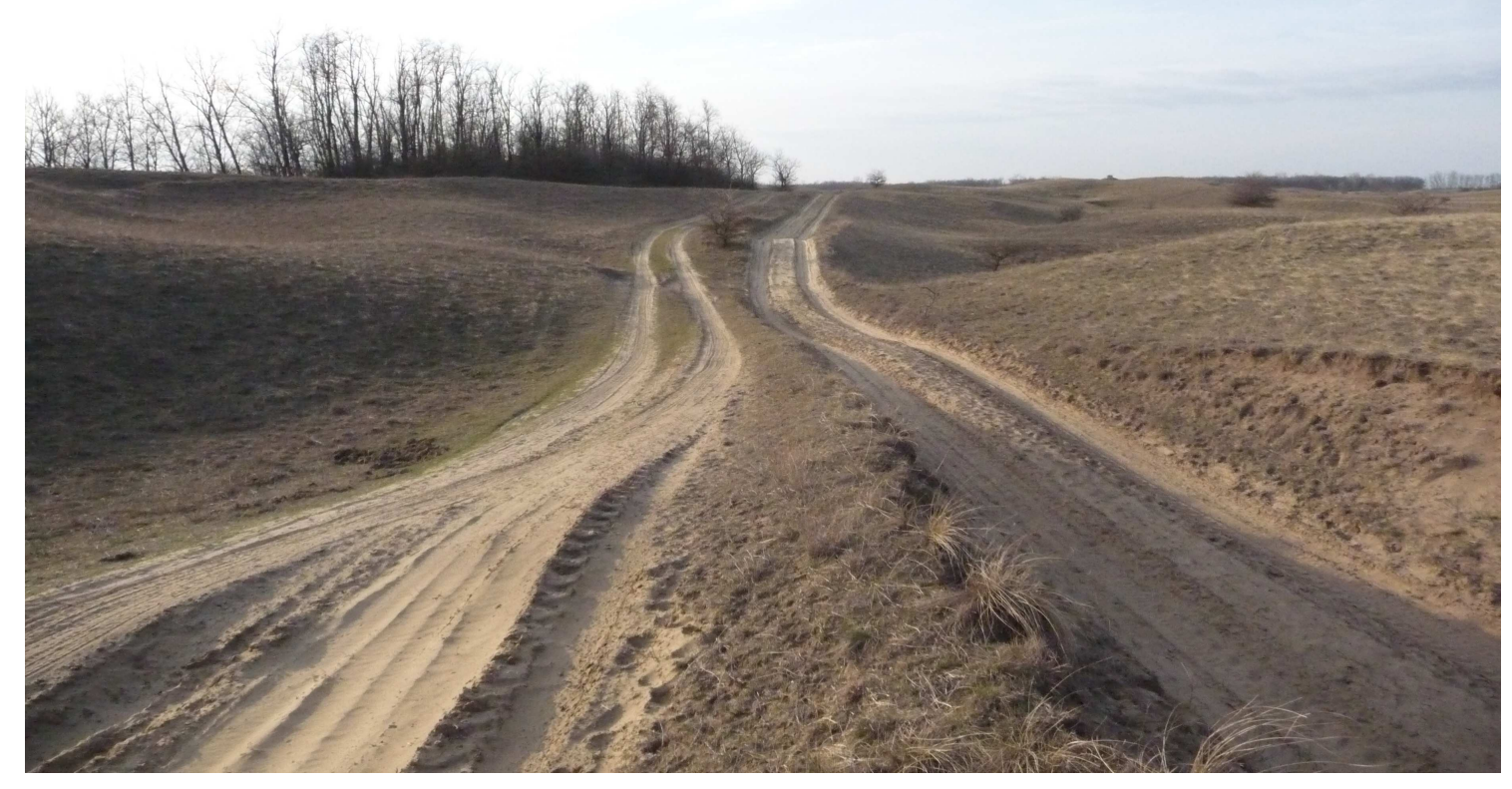

36. ábra. A gépjármüvek és a szélerózió együttes hatása

\subsection{Részösszegzés}

Az időben eltérő súllyal megjelenő tájhasználati módok tájtörténeti korszakokat határoznak meg. Az Illancs homokbuckáinak történetét a tájhasználat változása alapján (Bíró-Molnár 1998 nyomán) különböző időszakokra osztottam:

- A középkortól a 19. század közepéig: a külterjes legeltetés időszaka

A török hódoltság után az erdőirtások, a szántómüvelés és a szilaj legeltető állattartás következtében az egész Duna-Tisza közi táj meghatározó képévé a túllegeltett, növényzet nélküli homokbuckák váltak, melyeken a 18. századra nagy területen lendült mozgásba a homok. Az Illancsot a 18. század végén fátlan vegetáció és mozgó homokbuckák uralták (80\%), a jobb adottsággal rendelkező magaspartot övező területeken pedig már müvelt 
területek is előfordultak. Az ún. „homoksiványok” terjedésének megállítása a 19. századra központi kérdéssé vált, és elkezdődött a homok fásítása (főleg fekete (csomoros) nyárral), először kis területeken, kisebb sikerrel.

- A 19. század közepétöl az 1940-es évekig: tanyasi gazdálkodás időszaka

A 19. század második felében egyre több terület került mezőgazdasági művelés alá. A kistáj peremén szaporodtak a tanyák, a magaspartot övező területeken lévő települések egyre növekedtek. A peremterületeken virágzó szőlő és kertkultúra alakult ki. A fásítás újabb lendületet vett, immáron akáccal, nagyobb sikerrel. A tájban jelentősen csökkent a nyílt homokpuszta gyepek dominálta buckások területe, de a gyepek nyíltsága nem változott, fő használati módja a kisparaszti juhlegeltetés volt.

- Az 1950-es évektől az 1980-as évekig: az intenzív erdö- és mezögazdaság időszaka, a tanyák elnéptelenedése

A homokfelszínek fásítása intenzívebbé válik, és már nem csak akácot, hanem erdei és fekete fenyőt is telepítenek. Már nem elsődleges cél a homokmozgások megállítása. Nagyüzemi szőlőtermelés és nagytáblás mezőgazdasági müvelés váltja fel a kisparaszti gazdálkodási formát, így a tanyák háttérbe szorulnak, bizonyos területeken felszámolódnak. A fiatalság már a falvakba, városokba költözik. A kisparaszti legeltető állattartás csökkenése, és az erdők szélfogó hatása következtében a homoki gyepek folyamatosan záródnak. A csatornázás következtében már megfigyelhető a buckaközi mélyedések kiszáradása.

- 1980-as évektöl napjainkig: a társadalmi átalakulás és a szárazodás következményei Az 1980-as évek óta egyre több szántó- és szőlőterületet hagynak fel, nő a parlagok aránya. A tanyák elnéptelenedése és pusztulása tovább folytatódik. De ezzel párhuzamosan a hátság egyes részein az egykori tanyák újra lakottá válnak. A szárazodás következtében a természeti területek állapotromlása egyre fokozódik, és a mủvelt területen jelentős gazdálkodási nehézségek mutatkoznak. 


\section{AZ ILLANCS TERMÉSZETES ÉLŐHELYEINEK ÁLLAPOTA ÉS VÁLTOZÁSAI AZ ELMÚLT ÉVSZÁZADBAN}

\subsection{A Duna-Tisza köze jellemző élőhely-mintázatai és a szárazodás következményei}

\begin{abstract}
A Duna-Tisza közi hátság az Alföld egyik legkarakteriszti-kusabb része, hiszen a vizes élőhelyek és a száraz homokterületek váltakozása sajátos jelleget kölcsönöznek a tájnak (37. ábra).
\end{abstract} Nagytájszintü élőhelymintázatának típusai (homoki, lápi, sziki és ártéri jellegű élőhelyek) észak-déli lefutású zónákba rendeződnek (Bíró et al. 2007). A homokhátság központi részének két oldalán főként lápi jellegü élőhelyek dominálta zóna helyezkedik el. Ezt követi a szikes élőhelyek zónája, majd a két nagy folyó mentén az ártéri jellegű élőhelyek kerülnek túlsúlyba. Bíró (2006) szerint e regionális mintázat elsősorban a nagytájszintű geomorfológiával, a földtani felépítéssel és a vízáramlási viszonyokkal hozható össze-függésbe. A

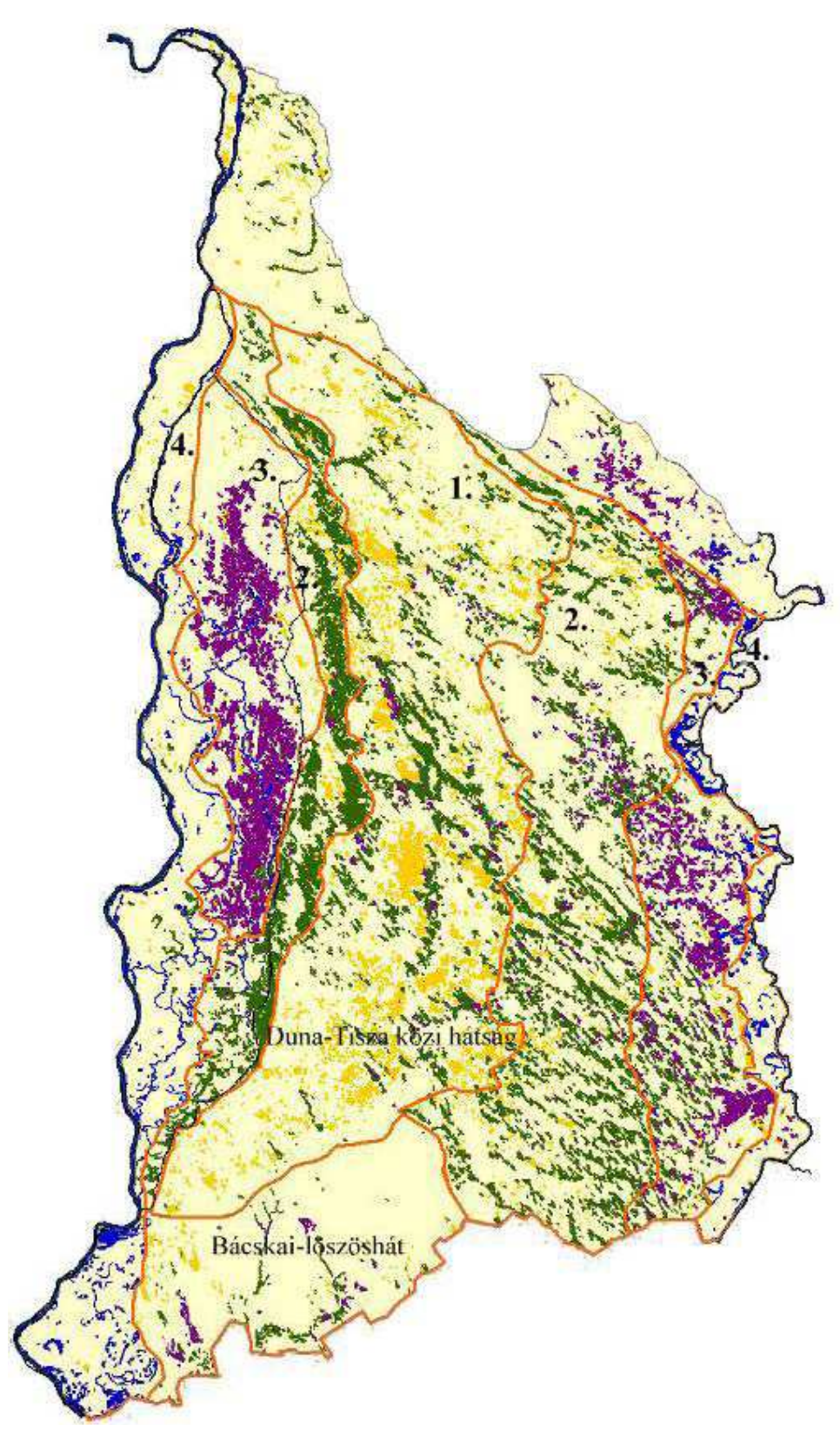

37. ábra. A Duna-Tisza köze regionális élőhely-mintázata (Bíró et al. 2007)

(sárga: homoki élőhelyek zónája; zöld: lápi jellegủ élőhelyek; lila: szikes élőhelyek; kék: ártéri jellegủ élőhelyek)

keleti illetve a nyugati oldal szikes és lápi élőhelyek által alkotott zónái a Duna-Tisza közi összetett vízáramlási rendszer regionális szintủ kiáramlási területével (Almási 2001) mutatnak területi átfedést. A táj mintázatának jellegzetességei lokális szinten is megfigyelhetőek: a Deák (2010) által a Dorozsma-Majsai Homokhátról leírt láprétfő-szikalj mintázat 
szerint a semlyékek ÉNy-i részén döntően lápi, míg a DK-i részén szikes élőhelyek helyezkednek el. Ezen mintázat kialakításához mind a lokális, mind a regionális vízáramlási rendszerek hozzájárulnak.

A homokbuckások Közép-Európa legveszélyeztetettebb élőhelyei közé tartoznak. Az elmúlt évszázadok antropogén tevékenységei hatására a természetes homoki élöhelyek kiterjedése visszaszorult, az állományok jelentősen fragmentálódtak (Molnár 2003). A homokbuckások természetes száraz élőhelyeinek regionális léptékü, részletes történeti tájökológiai jellemzését már Bíró (2008) és Molnár és munkatársai (2008) munkájából ismerjük.

A vízháztartásban bekövetkező változások a Duna-Tisza köze vizes élőhelyeit közvetlenül érintik. Már az 1990-es évek közepén Iványosi (1994) a Duna-Tisza közi talajvízszintek csökkenése kapcsán kiemeli a természetvédelmi területekre gyakorolt hatását, a védett szikes tavak élőhelyeinek és madárvilágának változását mutatja be. Boros - Biró (1999) kutatása szerint a 20. század végére a Duna-Tisza közi szikes tavak már közel 80 százaléka száradt ki. Később számos elemző tanulmány vizsgálta lokális léptékben a vizes élőhelyek átalakulását (Kovács et al. 2004, Schrett 2005, Dóka et al. 2006, Hoyk 2006, Varga 2009). Az Illancs területe a vízhiány tekintetében a legérintettebb zónában húzódik, mégis vizes és száraz élőhelyeinek a vizsgálata a szakirodalomban hiányos.

\subsection{Mintaterüilet és módszerek}

Mintaterületként két fennmaradt, ma már természetvédelmi oltalom alatt álló homokpuszta gyepet (Hajósi Homokpuszta Természetvédelmi Terület, Kéleshalmi Homokbuckák Természetvédelmi Terület), valamint két buckaközi mélyedésben található, egykor vizes élőhelyet (Borotától nyugatra lévő rét, Kélesi-tó és környéke) vizsgáltam meg. A tájhasználat-változásokhoz történeti térképeket (katonai térképezések, topográfiai térképek), valamint az élőhely-térképezéshez a 2005-ös országos légifelvételezés megfelelő szelvényeit, és az Általános Nemzeti Élőhely-osztályozási Rendszer (Á-NÉR) élőhelykategóriáit (Bölöni et al. 2007) használtam fel (6. melléklet). A területek fajkészletének, élőhely-mintázatának ismeretében a területek jelenlegi állapotát vázolom fel, különös tekintettel a kialakult jelentős vízhiány következményeire. A két száraz élőhelyek dominálta, homokbuckás mintaterület vizsgálatát másodsorban az is indokolja, hogy a kistájlehatárolások egyik sarkalatos pontja pont a Kéleshalmi Homokbuckák TT területe, hiszen több lehatárolás ezt már nem sorolja az Illancshoz, többek között morfológiája és növényzete alapján. A térinformatikai elemzéseket az ArcMap 9.3.-as szoftverrel végeztem. 


\subsection{Eredmények}

\subsubsection{A száraz élőhelyek állapota és változásai}

A vizsgált illancsi mintaterületek között rögtön szembetűnő, hogy a két terület közül a Hajósi Homokpuszta TT sztyepp fiziognómiájú, míg a Kéleshalmi Homokbuckák TT erdőspuszta képét mutatja (38. ábra). Ennek oka a tájhasznosításban keresendő. Mindkét védett természeti terület alapmátrixát évelő nyílt homokpuszta gyepek adják (39/a. ábra), melyen jelentősebb homoki borókás-nyarasok (M5) fordulnak elő - habár a Hajósi Homokpuszta TT-n a boróka hiányzik. Önmagában a tájlehatárolás vitás kérdését ez a tény nem döntheti el, hiszen a homoki borókásokról és nyarasokról semmilyen kétszázötven évnél idősebb adat nem áll a rendelkezésre, így azt sem tudjuk pontosan, hogy a 19. század előtt egyáltalán voltak-e borókás buckák a Kiskunságban (Molnár 2003). A homoki nyarasok galagonyás változata fordul itt elő, amelyet Deák (2010) a Dél-Kiskunság több részén megtalált.
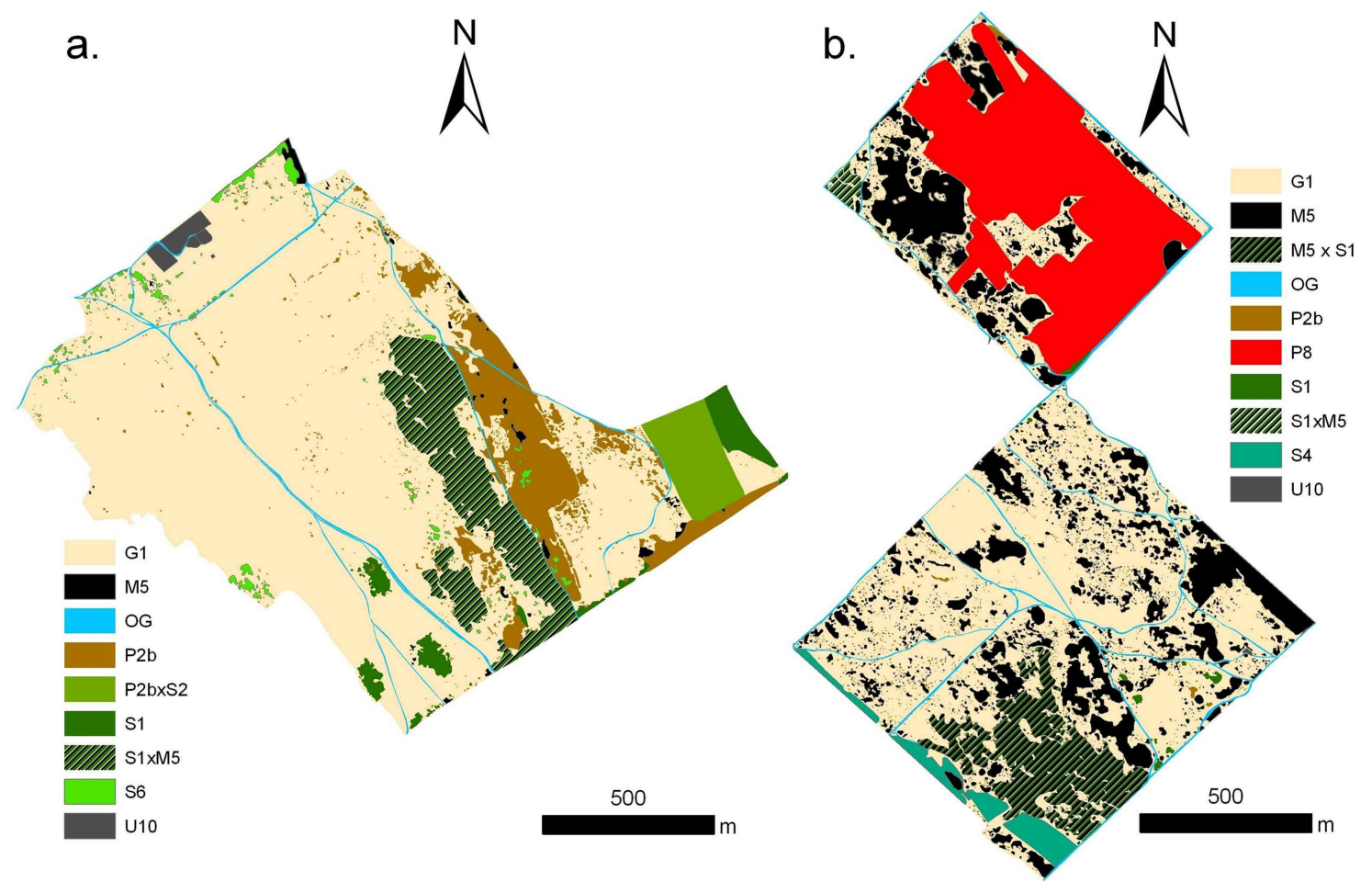

38. ábra. A vizsgált mintaterületek élöhelytérképei (az Á-NÉR osztályozás alapján)

a. Hajósi Homokpuszta TT; b. Kéleshalmi Homokbuckák TT

Az élőhely-kategóriák: G1: nyílt homokpuszta gyepek, M5: homoki borókás nyárasok, OG: taposott gyomnövényzet, P2b: száraz cserjés, P2BxS2: nemesnyáras és száraz cserjés, S1: akácos, S1xM5: akácoshomoki borókás nyáras átmenet, M5xS1: akácosodó homoki borókás nyáras, P8: vágásterület, S4: ültetett fenyőerdő, S6: nem őshonos fafajok spontán állományai, U10: tanyák. (Az egyes élőhelyek részletesebb jellemzését a 6. melléklet tartalmazza)

Mindkét száraz gyep telepített erdők (akác, erdei- és fekete fenyő) közé ékelődik be. A homok szemcsemérete különbözik a buckák szélárnyékos, szélnek kitett és buckaközi részein (Molnár 2003), mely megmutatkozik a gyepek zártságában és fajkészletében is. Ez a mintaterületünkön is érzékelhető. A buckatetőket, meredek buckaoldalakat magyar csenkesz (Festuca 
vaginata), homoki árvalányhaj (Stipa borysthenica) uralja, a szélnek, napnak kitett részeket a naprózsás típus, míg a szélárnyékosabb völgyeket a zártabb gyepü, kunkorgó árvalányhajas típus jellemzi. A Hajósi Homokpuszta TT érdekessége a rákosi csenkeszes (Festuca wagneri) átmeneti homoki gyep, mely átmenet a nyílt homoki gyepek és a homoki sztyepprétek között (TIR 2010). Fajkészletét a nyílt homoki sztyepprétek fajai (homoki árvalányhaj (Stipa borysthenica), báránypirosító (Alkanna tinctoria), magyar csenkesz (Festuca vaginata) stb.), sztyepprétfajok (élesmosófü (Chrysopogon gryllus), tejoltó galaj (Galium verum), mezei zsálya (Salvia pratensis) stb.), valamint e két típus közös fajai (kunkorgó árvalányhaj (Stipa capillata), homoki pimpó (Potentilla arenaria) stb.) alkotják (7. melléklet).

Mindkét védett területen jelentős számú egybibéjü galagonya (Crataegus monogyna) alkotta száraz cserjés folt fordul elő (39/b. ábra). Azonban a Hajósi Homokpuszta TT-n sokkal nagyobb kiterjedésben és összefüggő foltban jelenik meg, míg a Kéleshalmi Homokbuckák TT-n apró foltokban, szinte „mátrixot” képezve helyezkedik el. A ma domináns folyamatok közül elsődlegesen megemlítendő e gyepek intenzívvé váló cserjésedése, különösen a Hajósi Homokpuszta TT-n (sztyepp fiziognómiájának köszönhetően) (39/a. ábra), ami a természetvédelem aktív beavatkozását igényli.

a.

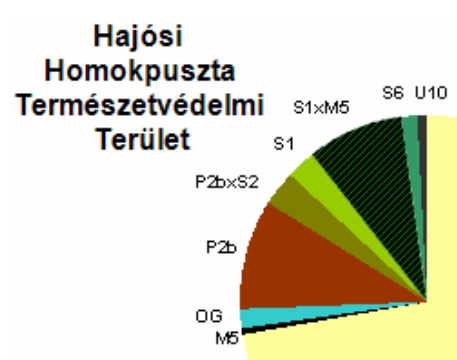

Foltszám: 1226 db

b.

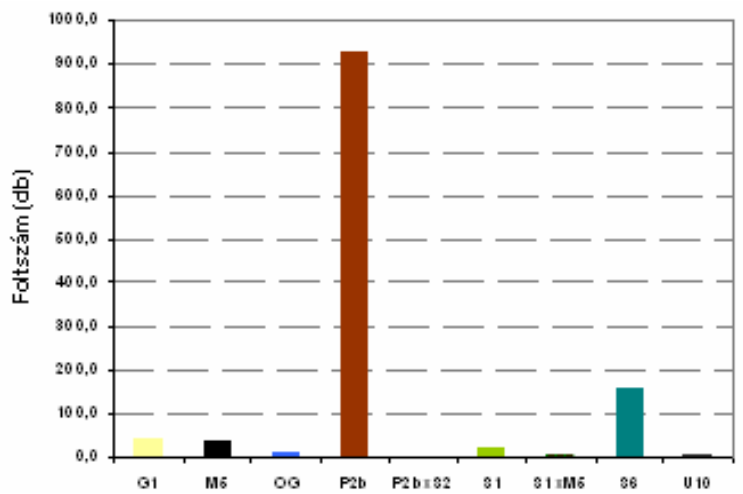

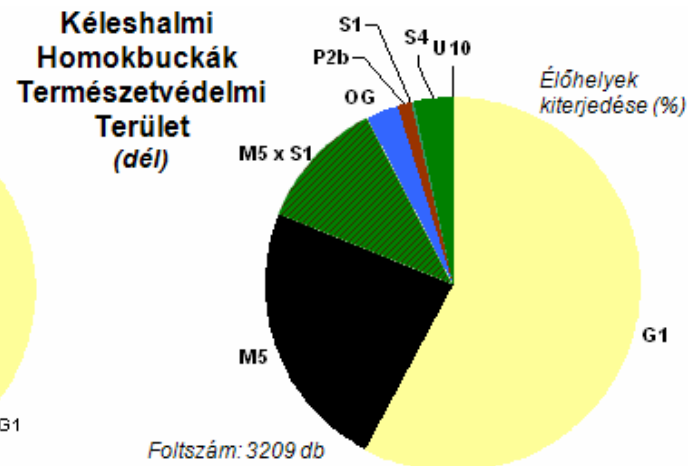

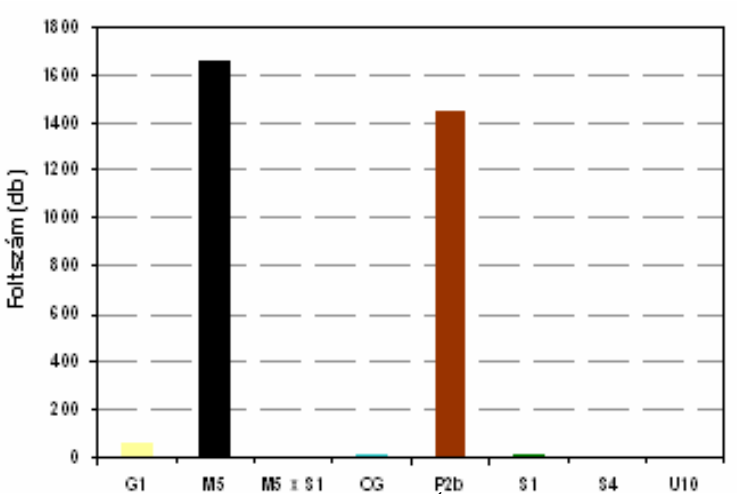

39. ábra. A Hajósi Homokpuszta TT és a Kéleshalmi Homokbuckák TT élöhelyfoltjainak a. kiterjedése; b. foltszám-analízise

\footnotetext{
${ }^{4}$ a Kéleshalmi Homokbuckák TT esetén egy erdőtűz miatt végzett szükségszerü fakivágások következményeként csak a legnagyobb részben épen maradt, déli részére történt az elemzést.
} 
A nyílt homokpusztagyep (G1) kiterjedése a különböző fiziognómia mellett hasonló arányú. E rétek olyan védett és fokozottan védett fajoknak adnak otthont, mint például a kései szegfü (Dianthus serotinus), a báránypirosító (Alkanna tinctoria), a homoki árvalányhaj (Stipa borysthenica), a homoki nőszirom (Iris arenaria), a tavaszi hérics (Adonis vernalis), a tarka sáfrány (Crocus reticulatus), a homoki vértő (Onosma arenarium), a homoki bakszakáll (Tragopogon floccosus) és a fényes poloskamag (Corispermum nitidum).

Mindkét, ma természetvédelmi oltalmat élvező terület a 20. század folyamán részlegesen mủvelés alá került (40. ábra), ami a táj mintázatára is jelentős hatást gyakorolt. A Hajósi Homokpuszta TT északkeleti részén szőlőművelést folytattak (40/a. ábra), melynek nyomait az élőhelytérképen a galagonyás foltok sorokba rendeződése (38/a. ábra), valamint a domborzatmodelljén a klasszikus homokbucka-formák hiánya mutatja (41/a. ábra). A Kéleshalmi Homokbuckák TT egy része szintén müvelés alá került ebben az időszakban (40/b. ábra). Két tanya, a hozzá tartozó szántókkal, valamint szőlővel és gyümölcsösökkel felfedezhető az 1950-1960-as évek térképein, ahol a felszínegyengetések nyoma ma is tükrözi a jelentős tájátalakítást (41/b. ábra). E terület északi részének jelentős hányadát a 20. század végére erdősítették, melyeket részben a 2000-es évek elején bekövetkezett erdőtủz nyomán kivágták (38. ábra (vágásterület)). A művelés felhagyása következtében a bolygatott területeken jelentős mértékben elszaporodtak az özöngyomok, leginkább a selyemkóró (Asclepias syriaca).
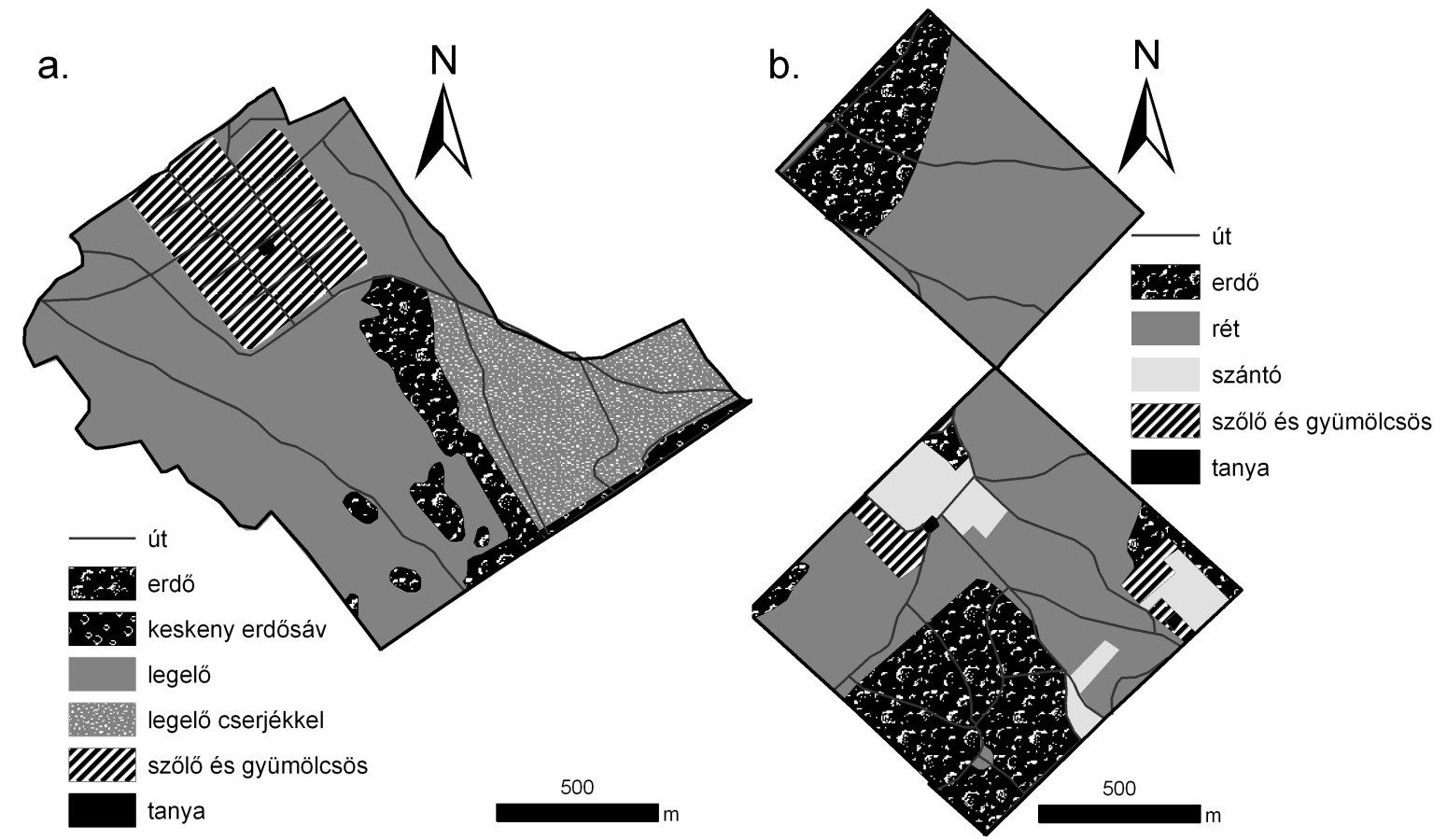

40. ábra. A vizsgált rétek tájhasználta az 1950-1960-as években (Gauss-Krueger térképek)

a. Hajósi Homokpuszta TT; b. Kéleshalmi Homokbuckák TT 
A két vizsgált terület közel azonos tengerszint feletti magasságon fekszik, és a rajtuk megfigyelt szintkülönbségek is közel azonosak (14 m és $15 \mathrm{~m})$. A pozitív formák közül a garmadabuckák és a maradékgerincek a jellemzőek (41. ábra). Gerincvonalaik átlagosan 200 méter körüliek. A Hajósi Homokpuszta lee oldalának lejtőszög-értékei nem haladják meg a $15^{\circ}$-ot, míg a Kéleshalmi Homokbuckák esetében meredekebb, de maximum $22^{\circ}$-os lejtőkkel is találkozhatunk. A buckák magassága egyik esetben sem haladja meg a 10 métert, ellentétben a fülöpházi homokbuckákkal, ahol Kiss és Tornyánszky (2006) átlagosan 10-15 m magas buckákat határozott meg mintaterületén. A fentebb említettek alapján azt mondhatjuk, hogy a Hajósi Homokbuckák TT mezoformáinak mérete csak kis mértékben tér el a Kéleshalmi Homokbuckák TT-n megfigyeltektől.
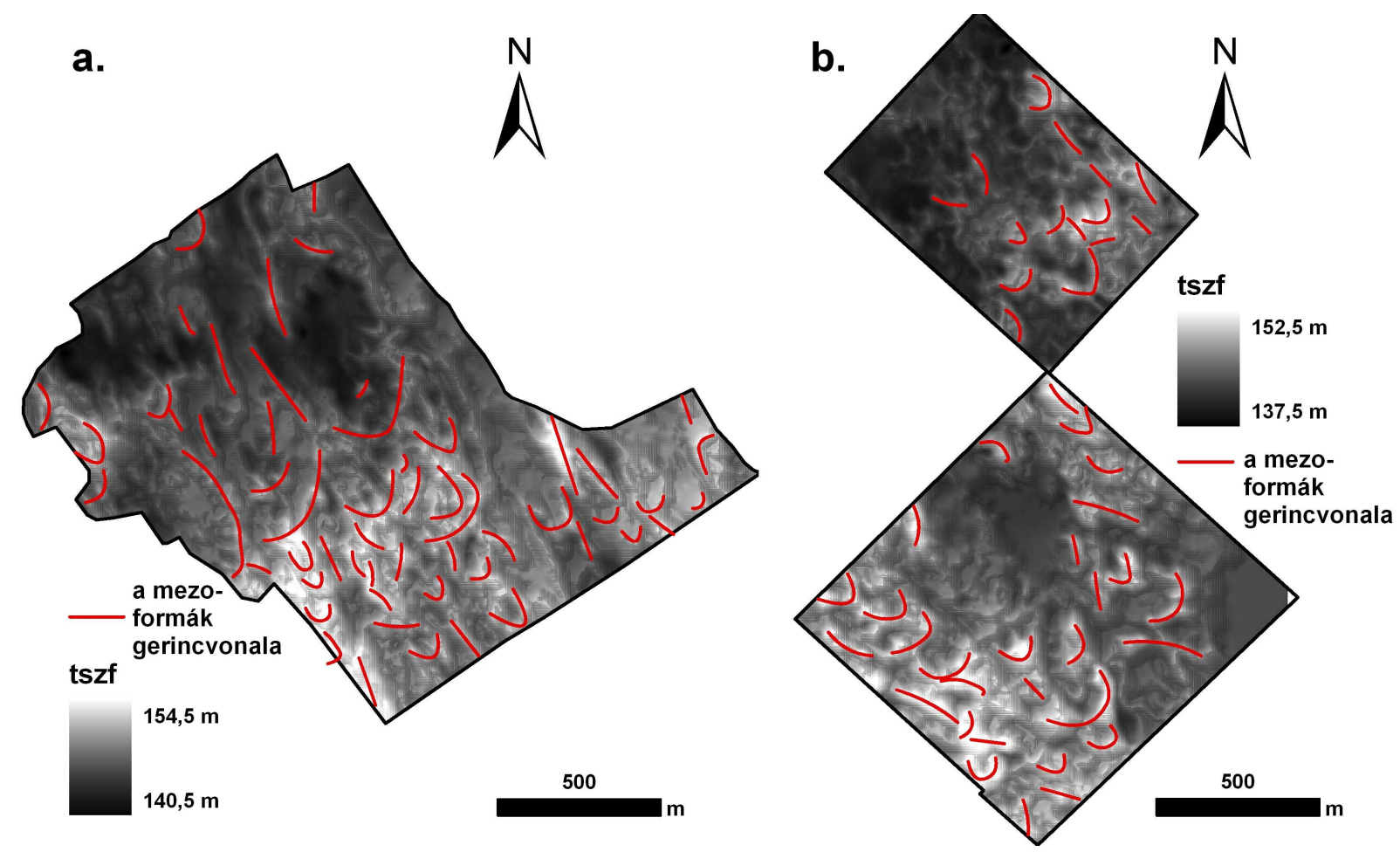

41. ábra. A vizsgált rétek domborzatmodellje az 1980-as évek topográfiai térképei alapján a. Hajósi Homokpuszta TT; b. Kéleshalmi Homokbuckák TT

\subsubsection{Az üde élőhelyek állapota és változásai}

A homokbuckások természetes élőhelyei közé tartoztak egykor a száraz, homoki gyepek mellett a buckaközi mocsarak és lápok is, a bucka (vonulatok) közötti mélyedéseket zárt füvü, serevényfüzes, láprét jellegü kékperjés üde gyepek dominálták (Bíró 2006). Az 1940-es évektől kezdődő csatornázás, valamint klímaváltozásnak köszönhető csapadékhiány töredékükre szorította vissza azokat. Az Illancs DK-i határvonalának buckaköze- 
iben is ilyen élöhelyeket találhatunk, történeti térképek alapján az 1780-as évektöl egészen az 1970-es évekig bezárólag (második és harmadik katonai térképezés, 1950-1960-as évek topográgfiai térképei) (lásd 13. ábra).

A Borota belterületétől Ny-ra elterülő gyep (42/a. ábra) a csatornázásokat megelőzően feltételezhetően lápi élőhelyekkel, valamint szikes rétekkel borított volt. A lápi jellegü élőhelyek a terület középső részének északi felén őrződtek meg leginkább, magassásrétek és kiszáradó kékperjés láprétek formájában. A talajvízszint süllyedését jelzi a kékperjés rétek galagonyásodása is (az egybibés a száraz cserjések képviselője, amely a száraz homoki gyepeken terjed leginkább e tájban) valamint az, hogy a terület középső részén több helyen eltolódtak a vegetációs zónák: a kékperjés rétek helyét a deflációs mélyedésekben a homoki sztyepprétek vették át, míg a kékperjés a területet metsző csatornába húzódott le.

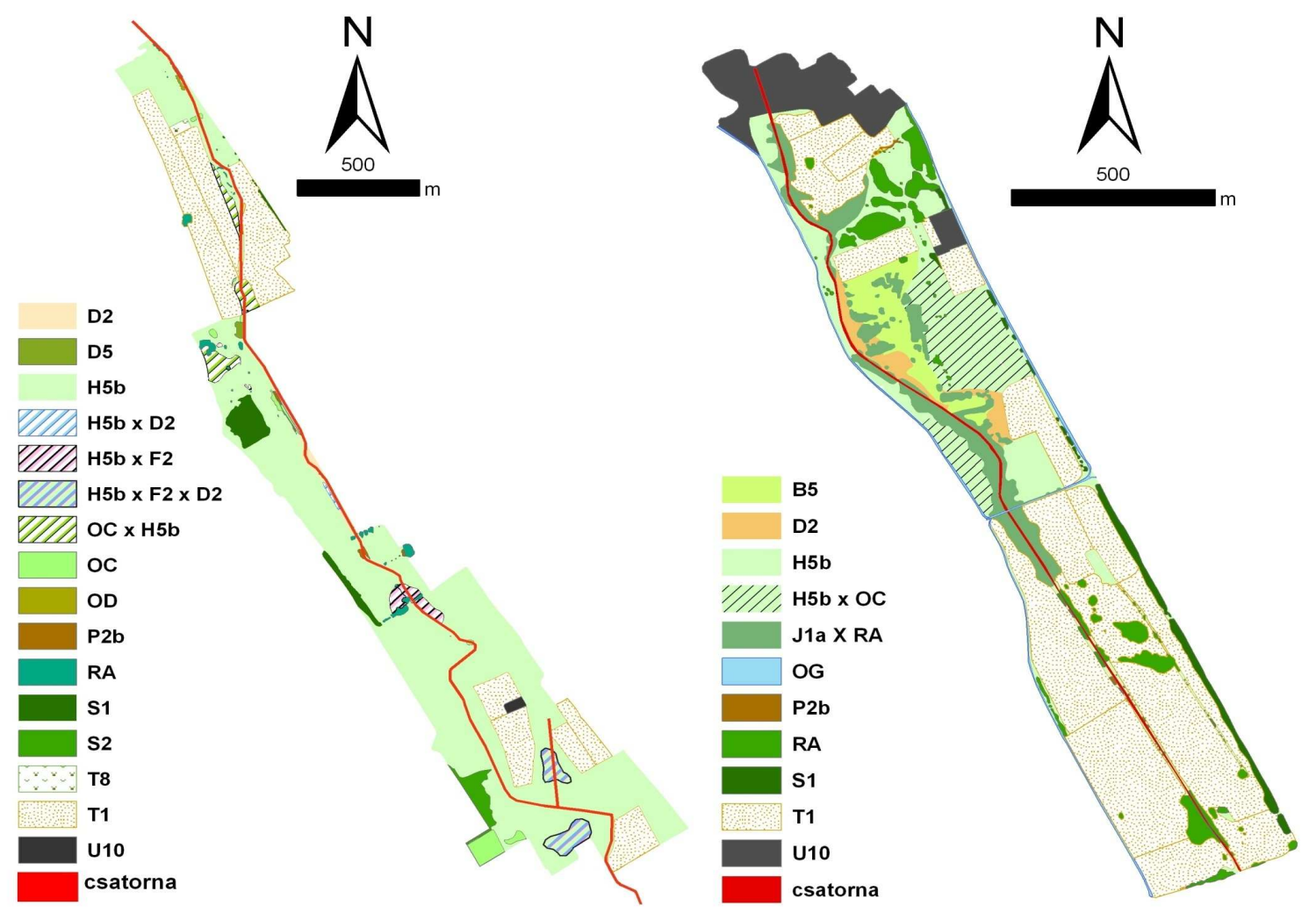

42. ábra. A vizsgált mintaterületek élöhelytérképei (az Á-NÉR osztályozás alapján)

a. Borotai legelö; $b$. Kélesi-tó és környéke

Az élőhely-kategóriák: B5: nem zsombékoló magassásrét, D2: kékperjés rétek, D5: magaskórós, H5b: homoki sztyepprétek, H5bxD2: kiszáradó, sztyeppesedő kékperjés láprét, H5bxF2: kiszáradó, sztyeppesedő szikes rét, H5bxF2xD2: kiszáradó, sztyeppesedő kékperjés láprét-szikes rét átmenet, H5bxOC: gyomosodó

homoki sztyepprét, J1axRA: őshonos fafajú fák és lápcserjések csoportja, OCxH5b: gyomos homoki sztyepprét, OC: jellegtelen száraz- vagy félszáraz gyepek, OD: lágyszárú özönfajok állományai, OG: taposott gyomnövényzet, P2b: száraz cserjés, RA: őshonos fajú facsoport, S1: akácos, S2: nemes nyárasok, T8:

kisüzemi szőlők és gyümölcsösök, T1: szántók, U10: tanya

(Az egyes élőhelyek részletesebb jellemzését a 6. melléklet tartalmazza) 
A szikes élőhelyeket csak a szikes rétek kiszáradt, sztyeppesedő, jellegtelenedő változatai képviselik, amelyek leginkább csak a terület középső részének déli felén ismerhetők fel. Ezeket - a futóhomok-betemetésre utaló - nádképủ csenkesz (Festuca arundinacea) és tarackos tippan (Agrostis stolonifera) alkotja, de ezek arányát meghaladja a sztyeppesedésre utaló csomós ebír (Dactylis glomerata) és a sovány csenkesz (Festuca pseudovina). Nagyobb arányban vannak jelen más homoki sztyeppréti fajok is, mint pl. a tövises iglice (Ononis spinosa) és egymás mellett van jelen a nádképü csenkeszes szikes rétek faja a sziki cickafark (Achillea asplenifolia) és a homoki sztyepprétek faja a mezei cickafark (Achillea collina). A kilúgozódás jeleit mutatja a tarackbúza (Agropyron repens) és a karcsú perje (Poa angustifolia) nagyobb aránya is. A terület legdélebbi és legészakabbi részén a korábbi szikes rétek teljesen homoki sztyepprétekké alakultak. A réten a selyemkóró fertőzöttsége nem jelentős, melyben jelentős szerepe van a juhlegeltetés fennmaradásának.

A Kélesi-tavat övező mintaterület a vizsgált borotai réttel ellentétben jelentős mértékben müvelés alá került az elmúlt évtizedekben, így csak a legmélyebb fekvésü területek őrizték meg az egykori élővilág maradványait. A magassásrétek és a kékperjés láprétek, valamint a kiterjedt rekettyefüz-állományok jelzik számunkra, hogy itt egykoron gazdag vízi élővilág lehetett. A területet a Borotát övező homokbuckák és a kéleshalmi homokbuckák felől jövő talajvíz-áramlások táplálják, melynek köszönhetően a vizes élőhelyek erősen száradó változatait még ma is megtalálhatjuk. E gyepen jellemző fennmaradt vizes élőhelyet kedvelő fajai a rekettyefüz (Salix cinerea), a kékperje (Molinia hungarica), a fehér nyár (Populus alba), a keskenylevelü gyékény (Typha angustifolia), vízimenta (Mentha aquatica). A mélyedést övező maradékgerincen zárt homoki sztyeppréteket találunk, valamint ezen élőhely jellemző az egykor felszántott, visszagyepesedő parlagok.

\subsection{Részösszegzés}

A 19. és 20. század antropogén és természetes folyamatai jelentős hatással voltak az Illancs természetes és természetközeli élöhelyeire. A száraz élöhelyeken döntően a tájhasználat változás és annak következményei okoztak jelentős átalakulásokat. A természetes élőhelyek fokozódó fragmentálódása is jelentős veszélyeztető tényező a 21. században. A telepített erdők közé beékelődő gyepmaradványokon a száraz cserjék elöretörése, valamint a selyemkóróval való fertőzöttség jelentős. A bolygatatlan természetes élőhelyek aránya rendkívül kicsi, melyeken az inváziós fertőzöttség sem jelentős. A két vizsgált, védett száraz homoki élöhelyekkel borított terület fajkészletében és geomorfológiájában nem mu- 
tatkozik akkora különbség, hogy a két terület külön kistájhoz legyen sorolható. A vizsgált üde élőhelyeken a zonáció kényszer-eltolódása dominál: ma csak a diszkrét mélyedések legmélyebb részein azonosíthatók a szikes és lápi élőhelyek maradványai, de a talajvízszint-süllyedés következtében ezek az élőhelyek is legtöbbször homoki sztyepprétekbe alakultak át vagy sztyeppesedő változataik jelentek meg. A vizes élőhelyeket átvágó csatornákban vízvisszatartásra alkalmas létesítmény csak a borotai rét felső szakaszán van, állandóan zárt állapotban, melynek eredményeképpen több kékperje figyelhető meg a mütárgy feletti szakaszon, bizonyítva a vízmegtartás jelentőségét e tájban.

A jelenlegi tájhasználatnak is jelentős szerepe van a tájkép alakulásában. A borotai réten alig van selyemkóró, mely egyrészröl a természetes (bolygatatlan) élöhelyek nagy arányának köszönhető, valamint egyértelműen a juhlegeltetés pozitív következménye. A terület homoki sztyepprétjeinek természetessége közepes, a szúrós növények (pl. tövises iglice) dominanciája jelentős a legeltetés miatt. A peremi részek jobb természetességű homoki sztyepprétjei hozzájárulnak a parlagterületek regenerálódásához. 


\section{A SZÁRAZODÁS HATÁSA EGY BOROTAI MINTATERÜLET PÉLDÁJÁN}

\subsection{Buckavonulatok közötti mélyedések az Illancson}

A buckavonulatok közötti mélyedések a tájhatár vonatkozásában már korábban megjelentek a dolgozat 4. fejezetében. Ezeket a mélyedéseket a helyiek elmondása szerint még az 1970-es években is nyár elejéig víz borította. Később, a csatornázás és a vízhiány miatt kialakuló talajvízszint-csökkenés következtében állandó vízborításuk megszűnt, bizonyos részeik szántóföldi művelés alá kerültek (lásd 42. ábra).

A kistáj természetföldrajzi adottságainak vizsgálatakor szembetűnő volt, hogy a kistájban egy ilyen buckák közötti mélyedést (43. ábra) a Kreybig-féle Átnézetes Talajtani Térkép szikesnek jelölt. Még inkább érdekesnek tűnt, hogy az agrotopográfiai adatbázis ennek egy részét ráadásul szoloncsák-szolonyec talajként ábrázolja. Ha visszatekintünk az előző fejezet bevezetésében bemutatott Duna-Tisza közi élőhelyek regionális zonációjának a térképére (37. ábra), akkor azt látjuk, hogy a kistáj teljes egésze a lápi jellegü élőhelyek zónájába esik.
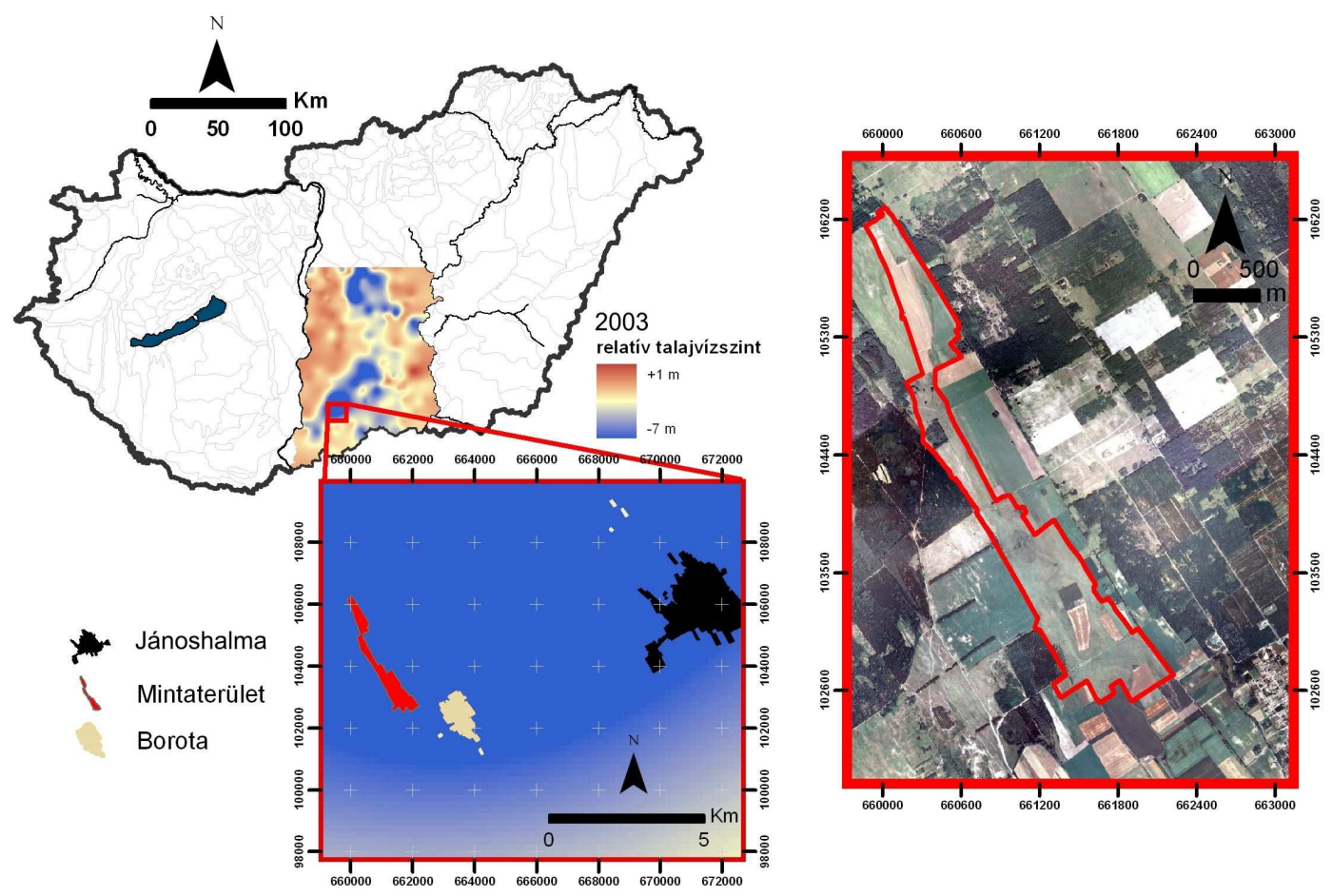

43. ábra. A borotai vizes (szikes) élőhelyek boritotta terület elhelyezkedése

A területen a Kreybig-féle Átnézetes Talajismereti Térkép készítésekor történt talajmintavétel és laborelemzés, mely lehetôséget ad ennek a területnek a változáselemzésére. Kérdésként merülhet fel, hogy valóban volt szikes talaj az Illancson? Bizonyítják-e ma a talajtani adottságok és a növényzet, hogy egykoron szikes élőhelyek voltak? Egyál- 
talán a terület északnyugati része, amelyen 1949-ben nem történt mérés, lehetett-e szikes? Hogyan változtak a talaj tulajdonságai és a terület élöhelyei, fajkészlete a vízhiány következtében? E fejezet ezekre a kérdésekre keresi a választ.

\subsection{Mintaterület és módszerek}

A mintavételezés a Kreybig-féle átnézetes talajtani térképsorozat 5462/4-es szelvényén 52-es számmal jelzett mintavételi helyen történt, valamint további két helyen a terület ÉNy-i nyúlványán és a középső részen (44/a. ábra) (8. melléklet). A területre eső Kreybig mintavételi pont jól beazonosítható volt, ezért viszonylag nagy pontossággal lehetett ugyanott elvégezni a 2008-as mintavételt is. A mintavételi pont körül sem morfológiai, sem vegetációbeli eltéréseket nem tapasztaltunk, ezért a talajparaméterekben észlelt különbségek nem származhatnak a mintavételi hely pontatlan rekonstruálásából. A talajvízszint a területen mind a 3 mintavételi helyen 6 méter alatt volt, ezért a talajmintavételt nem a talajvíz szintjéig, hanem egységesen 2 m-ig, 20 cm-enként végeztük el. A laboratóriumi munka során pH és összsó mérés (MSZ-08-0206/2-78), szervesanyag-tartalom meghatározás (MSZ 21470/52-1983), karbonáttartalom-mérések (MSZ08-0206/2-78) zajlottak le ${ }^{5}$. A szemcseeloszlás-vizsgálatot a MSZ 080205 szabvány alapján végeztem, mindhárom mintavételi helyre (43/a. ábra). Az élőhely-térképezés során az Általános Nemzeti Élőhelyosztályozási Rendszer (Á-NÉR) élőhelykategóriáit használtam (Bölöni et al. 2007) és a területen előforduló növényfajokról fajlistát készítettem (10. melléklet). A fennmaradt vizes (és szikes) élőhelyek fajkészletét minden beazonosítható foltra külön elemeztem.

A terület első talajtani szempontú térképezése 1949-ben valósult meg a Kreybig Lajos által kezdeményezett és vezetett országos átnézetes talajismereti térképezés során. A felmérés a mintaterület jelentős részét II. osztályú, erősebben szikes kategóriába sorolta (44/b. ábra). A besorolás alapja a terepi és a laboratóriumi vizsgálatok voltak. Az akkori felvételezés során a mintaterület DK-i részén történt talajmintavétel, a 43/b. ábrán jelölt piros ponttal jelölt helyen. A mintavételi helyet mély sík jelzővel látták el (2. táblázat). A nyugvó vízszintet a furatban $130 \mathrm{~cm}$-en állapították meg. A talajszinteket morfológiailag mind a tömött kategóriába sorolták (amely ma már nem releváns kategória), színük a szürkésbarnától a szürkéssárgáig változott. A sótartalom a talaj felső $30 \mathrm{~cm}$-ben meghaladta a 0,05\%-ot, valamint a pH elérte az erősen lúgos tartomány alsó határát (3. táblázat).

A Kreybig-felvételezést követően, az 1960-as évek végén a területen csatornát mélyítettek ÉNy-DK irányban a felesleges vizek elvezetése céljából.

\footnotetext{
${ }^{5}$ A mérések bizonytalanságai: összes sótartalom (mg/l): 4,58\%; fenolftalein lúgosság: 5,93\%; humusz\%: 5\%; CaCO3\%: 4,9\%; Arany-féle kötöttség: 1,22\%; pH (H2O): 0,16\%. A felhasznált talajvizsgálati eszközök és módszerek részletes leírását a 9 . melléklet tartalmazza.
} 
a.

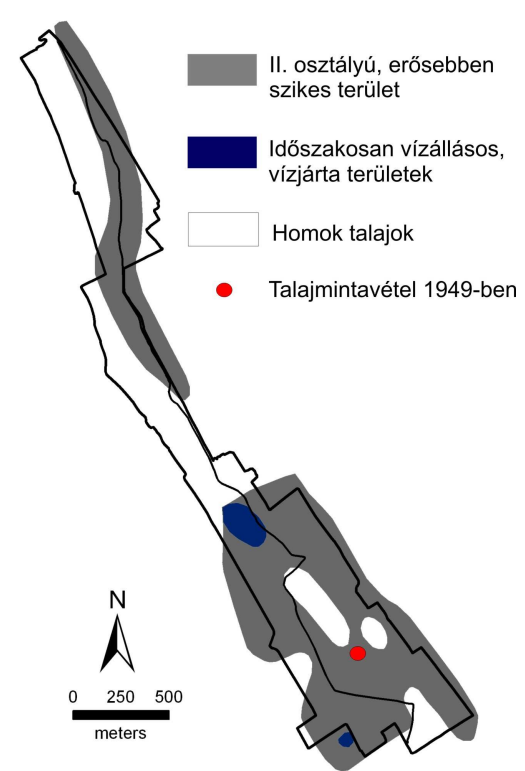

b.

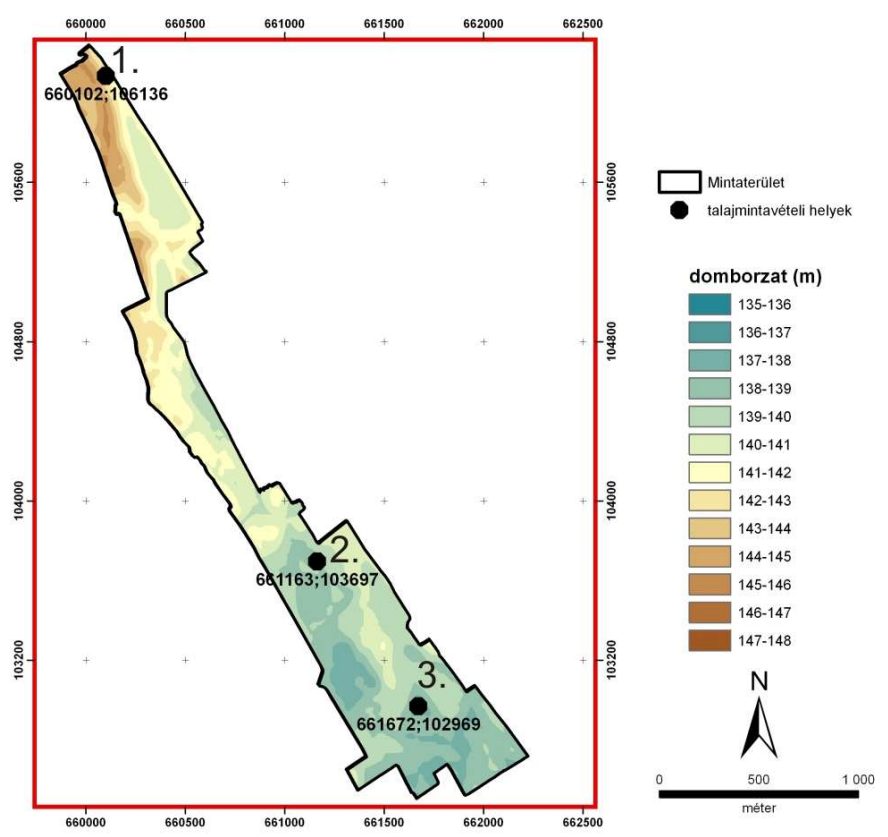

44. ábra. a. A mintaterület felmérése 1949-ben (Kreybig-féle Átnézetes Talajismereti Térkép); b. A mintaterület domborzatviszonyai és a mintavételi pontok helye

2. táblázat. A terepi felmérés eredményei (Kreybig 1949)

\begin{tabular}{|c|c|c|c|c|c|c|c|c|c|}
\hline $\begin{array}{c}\text { Vizsgálati } \\
\text { hely száma }\end{array}$ & $\begin{array}{c}\text { Mély- } \\
\text { ség }\end{array}$ & $\begin{array}{c}\text { vizsgálati } \\
\text { hely fekvé- } \\
\text { se }\end{array}$ & $\begin{array}{c}\text { réteg- } \\
\text { vastag- } \\
\text { ság (cm) }\end{array}$ & $\begin{array}{c}\text { rétegek } \\
\text { színe }\end{array}$ & $\begin{array}{c}\text { fizikai } \\
\text { talaj- } \\
\text { féleség }\end{array}$ & $\begin{array}{c}\text { Morfo- } \\
\text { lógiai } \\
\text { struktúra }\end{array}$ & $\begin{array}{c}\mathbf{p H} \\
\text { vízben }\end{array}$ & $\mathbf{C a C O}_{3}$ & $\begin{array}{c}\text { Utolsó } \\
\text { termény }\end{array}$ \\
\hline $\mathbf{5 2}$ & 30 & mély sík & $0-30$ & $\begin{array}{c}\text { szürkés- } \\
\text { barna }\end{array}$ & szikes & tömött & 9,5 & $\begin{array}{c}+++ \\
\text { (erösen } \\
\text { pezseg) }\end{array}$ & legelő \\
\hline & $30-60$ & $\begin{array}{c}\text { szürkés- } \\
\text { barna }\end{array}$ & szikes & tömött & $\begin{array}{c}++ \\
\text { (közepe- } \\
\text { sen pe- } \\
\text { zseg) }\end{array}$ & \\
\hline & & $60-130$ & $\begin{array}{c}\text { szürkés- } \\
\text { sárga }\end{array}$ & szikes & tömött & & $\begin{array}{c}+++ \\
\text { (erősen } \\
\text { pezseg) }\end{array}$ & \\
\hline
\end{tabular}

3. táblázat. A laborvizsgálat eredményei (Kreybig 1949)

\begin{tabular}{|c|c|c|c|c|c|c|c|c|c|c|c|}
\hline \multirow{2}{*}{\multicolumn{2}{|c|}{$\begin{array}{l}\text { A vizsgált } \\
\text { minta sor- } \\
\text { száma és } \\
\text { mélysége }\end{array}$}} & \multirow{3}{*}{$\begin{array}{c}\begin{array}{c}\text { fizikai } \\
\text { talajféleség }\end{array} \\
\text { szikes } \\
\end{array}$} & \multirow{3}{*}{$\begin{array}{c}\mathbf{p H} \\
\left(\mathbf{H}_{2} \mathbf{O}\right) \\
9 \\
9\end{array}$} & \multirow{3}{*}{$\begin{array}{c}\begin{array}{c}\text { pH } \\
\text { (KCl) }\end{array} \\
\\
8,8 \\
\end{array}$} & \multirow{3}{*}{$\begin{array}{c}\mathrm{CaCO}_{3}(\%) \\
19,7 \\
\end{array}$} & \multirow{3}{*}{$\begin{array}{c}\begin{array}{c}\text { összes } \\
\text { vízben } \\
\text { oldha- } \\
\text { tó só } \\
(\%)\end{array} \\
0,06 \\
\end{array}$} & \multirow{3}{*}{$\begin{array}{c}\mathrm{Na}_{2} \mathrm{CO}_{3} \\
\%) \\
0,03 \\
\end{array}$} & \multirow{3}{*}{$\begin{array}{c}\begin{array}{c}\text { Légszáraz } \\
\text { talaj ned- } \\
\text { vessége } \\
(\%)\end{array} \\
2,15 \\
\end{array}$} & \multicolumn{3}{|c|}{$\begin{array}{c}\text { Kapilláris víz- } \\
\text { emelés óra múl- } \\
\text { va }(\mathbf{m m})\end{array}$} \\
\hline & & & & & & & & & 5 & 20 & 100 \\
\hline \multirow[t]{2}{*}{52} & $0-30$ & & & & & & & & 70 & 270 & 390 \\
\hline & $30-60$ & szikes & 8,8 & 8,9 & 23 & $<0,03$ & 0,02 & 1,67 & 230 & 440 & 820 \\
\hline
\end{tabular}




\subsection{Eredmények}

\subsubsection{A mintaterület talajtulajdonságainak alakulása napjainkban}

A legmagasabb tengerszint feletti magasságon fekvő 1. mintavételi hely réti csernozjom talaj. A terület az elmúlt évtizedek alatt művelés alá került, a szántás nyomait még $40 \mathrm{~cm}$ mélységben is bomlásban lévő szerves anyag maradványok jelzik. Az A szint $55 \mathrm{~cm}$ mély, sötétbarna színü, morzsás szerkezetü. Humusztartalma felszínközelben rendkívül jelentős (6\%), lefelé fokozatosan csökken, de értéke még az AB átmeneti zónában (55-75 $\mathrm{cm}$ ) is $1,5 \%-2 \%$. A B szint sárgásbarna, 90 cm-től vaskiválások, mangánfoltok figyelhetőek meg, különösen 130-140 cm-ig. A szürkéssárga színủ C szint 140 cm-en kezdődik. A sótartalom az egész szelvényben nem haladja meg a 0,03 \%-ot. Kalcium-karbonát tartalma jelentős (15\%-30\%), eloszlása mélyben karbonátos profilt mutat. Fenolftalein-lúgossága kicsi, nem éri el a 0,05\%-ot. A talaj kémhatása a gyengén lúgos tartományban mozog. A vízhatás nyomát a vaskiválások, rozsdafoltok, mangánfoltok jelzik.

A terület közpén elhelyezkedő 2. mintavételi hely ma morfológiáját tekintve sztyeppesedő réti szolonyec talaj képét mutatja, az előbbinél egy egykor jelentősebb vízborítás nyomát tükrözi. Az A szint $45 \mathrm{~cm}$, sötétbarna színü, morzsás szerkezetü. Gyökérmaradványok 30 cm-ig tapasztalhatóak. A és B szint átmenete éles. A felső $20 \mathrm{~cm}$-en az 1. számú mintavételi helyhez képest kisebb, de még mindig jelentős a humusztartalom (5\%). B szintje 45-85 cm, sárgásbarna színű, homokos vályog textúrájú. A talaj viszonylag sekély, a talajképző kőzet már 85 cm-en megjelenik, szürkéssárga színű. Sótartalma ma nem haladja meg a szelvényben a 0,03\%-ot, nátrium-karbonát-tartalma pedig a 0,05\%-ot. A pH a felszínen a gyengén lúgos tartományba esik $(\mathrm{pH}$ 7,9), és a $\mathrm{B}$ szinttől kezdve végig a gyengén lúgos és a lúgos kémhatás határán változik. $\mathrm{CaCO}_{3}$ tartalma jelentős, a $\mathrm{B}$ szintben mutat maximumot (felszínhez közel karbonátos). Vaskiválások már 20 cm-től megjelennek a szelvényben, de a legjelentősebb mennyiségben 120 cm-től lefelé találhatóak.

A legdélebben fekvő, 3. mintavételi hely ma morfológiáját tekintve a réti csernozjom kategóriájába sorolható. Az A szint $45 \mathrm{~cm}$ mély, sötétbarna színű, morzsás szerkezetű. Humusztartalma szintén jelentős (4,5\% a felső $20 \mathrm{~cm}$-en), gyökérmaradványok $30 \mathrm{~cm}$-ig figyelhetőek meg. B szint sárgásbarna, homokos vályog textúrájú, mely nem éles határral különül el a szürkéssárga C szinttől (B-C átmenet 100-135 cm). A sótartalom nem haladja meg a furatban a 0,03\%-ot, a nátrium-karbonát tartalom 80-100 cm-en viszont eléri a 0,05\%-ot. 


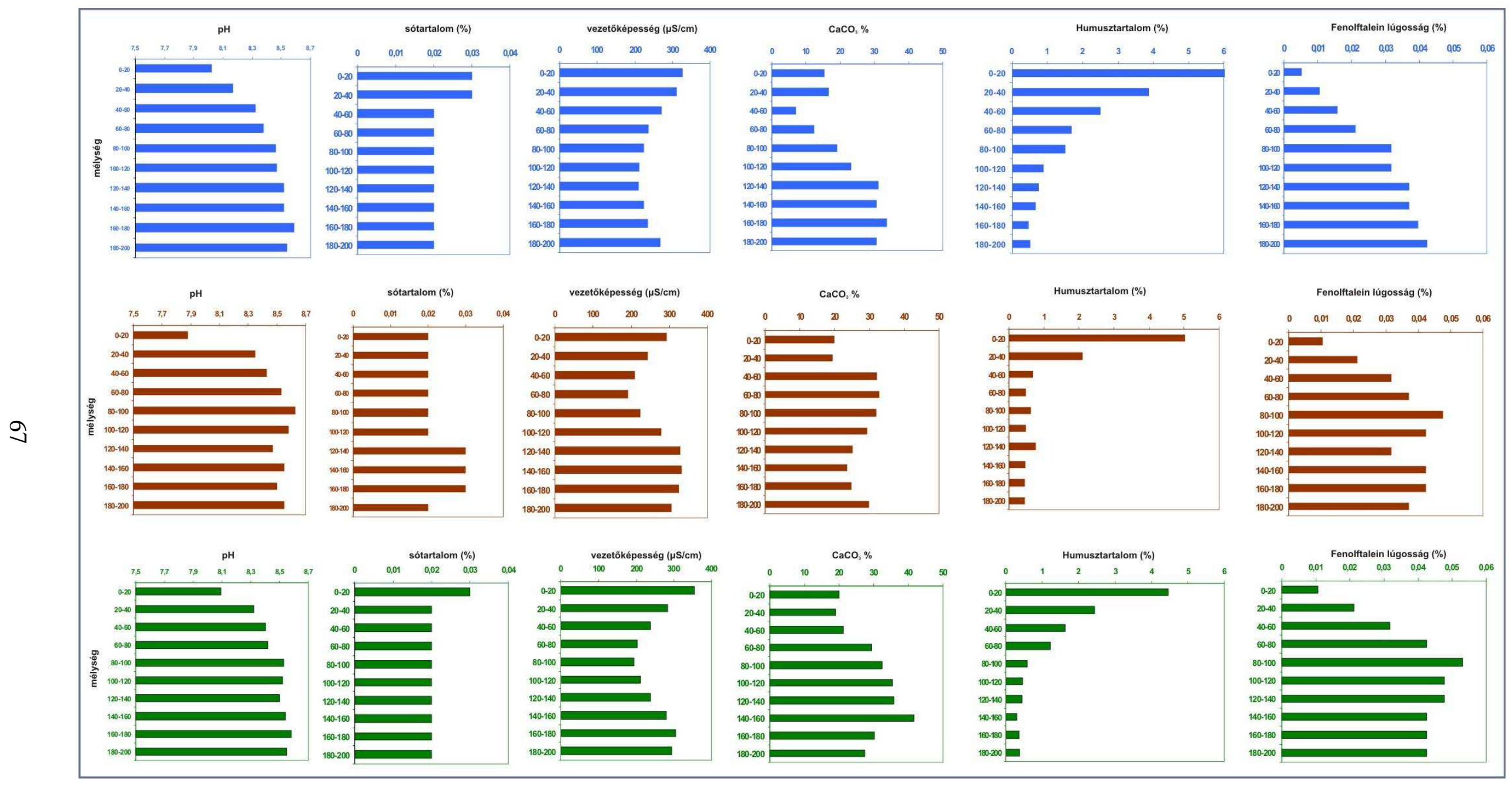

45. ábra. Az alapvzsgálati paraméterek alakulása a mintapontokban

(kék: 1. mintavételi hely (ÉNy), piros: 2. mintavételi hely (a terület közepén); zöld: 3. mintavételi hely (DK)) 
A karbonát-tartalom végig jelentős, 160-180 cm-en megközelíti a 40\%-ot, ami mésziszap réteg kialakulását feltételezi. A rozsdafoltok már $50 \mathrm{~cm}$-en megjelennek, de legjelentősebb mennyiségben $140 \mathrm{~cm}$ alatt mutatkoznak. $190 \mathrm{~cm}$-től mészkonkréciók is megfigyelhetőek. A pH a felszínen gyengén lúgos (pH 8,1), és $80 \mathrm{~cm}$-től (a 2. mintavételi helyhez hasonlóan) a gyengén lúgos és a lúgos tartomány határán mozog.

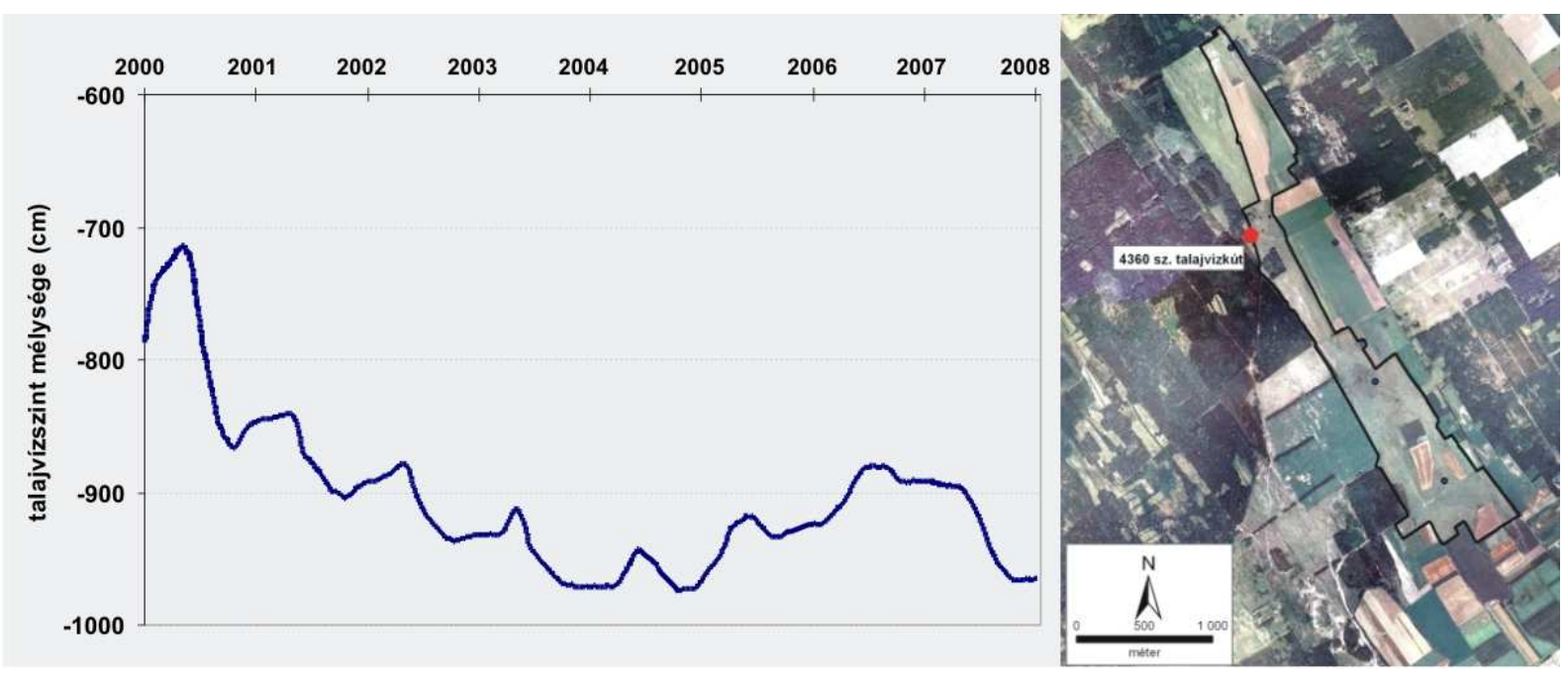

46. ábra. A talajvízszint változása a 4630 sz. talajvízkútban (forrás: VITUKI)

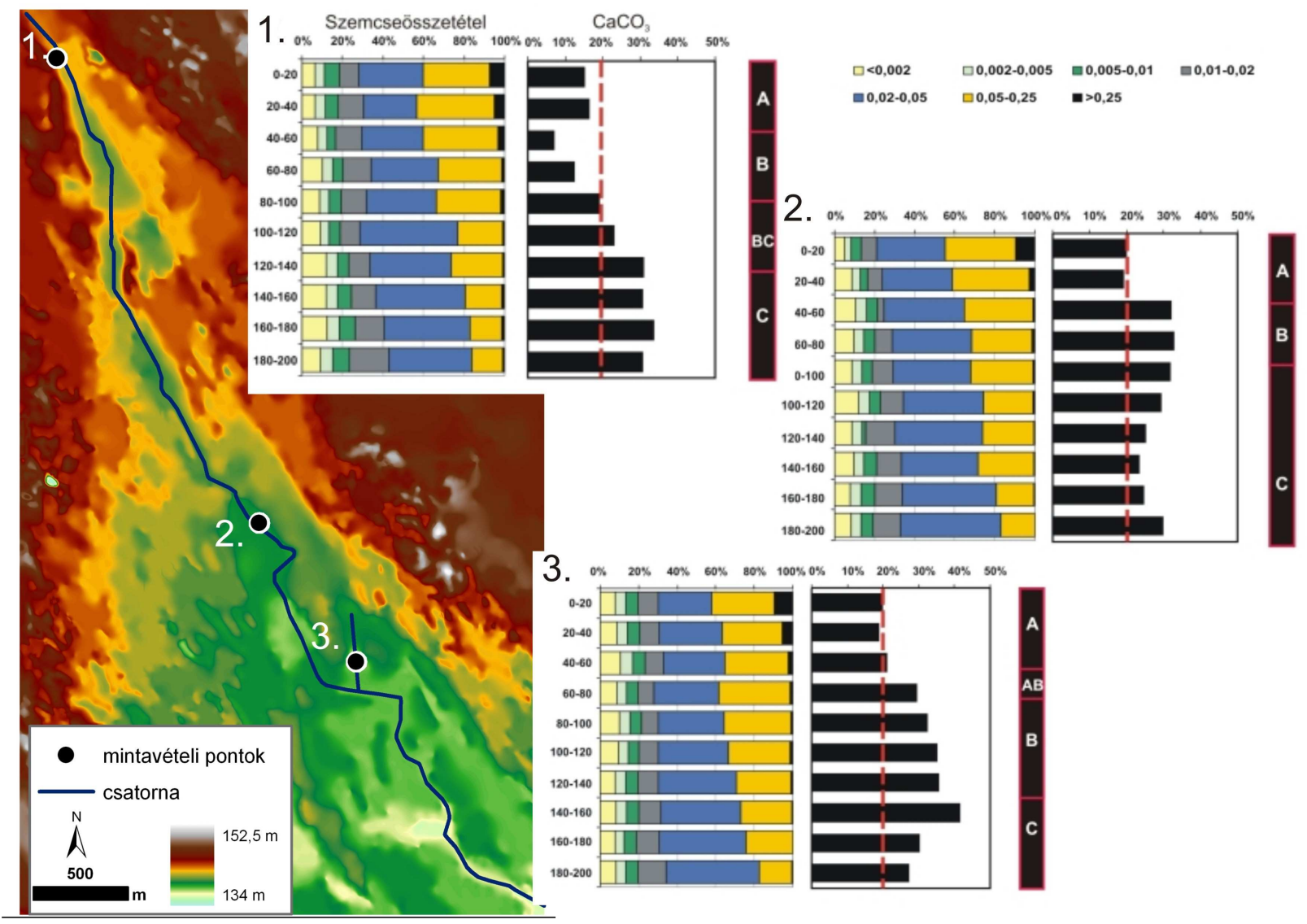

47. ábra. A szemcseösszetételi és a $\mathrm{CaCO}_{3}$-tartalom vizsgálatok összesített eredményei 
A területen 2000-ben létesült talajvízszint-megfigyelö kút az 1. és a 2. mintavételi hely között, mely alapján csak a 2000-2008-ig terjedő periódusban a talajvízszintsüllyedés megközelíti a másfél métert (46. ábra). Ezen adatok (valamint a réten állatitatásra használt ásott kutak szerint) a talajvízszint az egész vizsgált területen 6 méter alatt van, így ebben az esetben kijelenthető, hogy a talajvíz szintje már nincsen közvetlen hatással a talajokra.

A szemcseösszetételi diagrammokban a vályog textúra kategóriával jellemezhető kőzetliszt dominanciája egyértelműen jelzi számunkra, hogy mindhárom furat e buckavonulatok közötti mélyedésben található, melyet a holocén homokmozgások némileg befolyásoltak (homoklepel). Ennek bizonyítéka lehet az 1. mintavételi hely A és B szintjének, valamint a másik két mintavételi hely A szintjeinek jelentősebb finomhomok ( $\varnothing=0,05-0,2 \mathrm{~mm})$, csekély durva homok $(\varnothing=0,2-2 \mathrm{~mm})$ tartalma, illetve ezen szintek kisebb mértékü $\mathrm{CaCO}_{3}$ tartalma. A kalcium-karbonát tartalom különbségei azonban a kilúgozás folyamatát is mutatják (a fentebb említett szintek karbonáttartalma 15-20\% között marad, míg a további szintekben jóval 20\% fölé emelkedik). A délkeleti, legmélyebb tengerszint feletti magassággal rendelkező vizsgálati helyen 140-160 cm-en a $\mathrm{CaCO}_{3}$-tartalom meghaladja a 40\%-ot. Az 1949-es felvételezés a talajvíz szintjét 130 cm-en mélyen állapította meg, ahol ma 130-140 cm között jelentős mangán és vaskiválás figyelhető meg. Ezek az adatok összességében arra utalnak, hogy ez a zóna a csatornázást megelőző időszakban a talajvízszint ingadozási zónájának része volt, melyet alátámaszt a jelentős kalcium-karbonát felhalmozódás is, mely a szemcseméret már majdnem kétmódusú görbéjével együtt (uralkodó $0,02-0,05 \mathrm{~mm}$, valamint a jelentősebb $0,002 \mathrm{~mm}$ alatti frakció) mésziszap jelenlétét mutatja, amely a Duna-Tisza közi deflációs mélyedések jellemzője (Miháltz 1950, Fügedi et al. 2005). A talajképző kőzet mind a 3 furat esetén lösz, melyet a C-szintek szemcseösszetételi diagrammja támaszt alá (48. ábra).

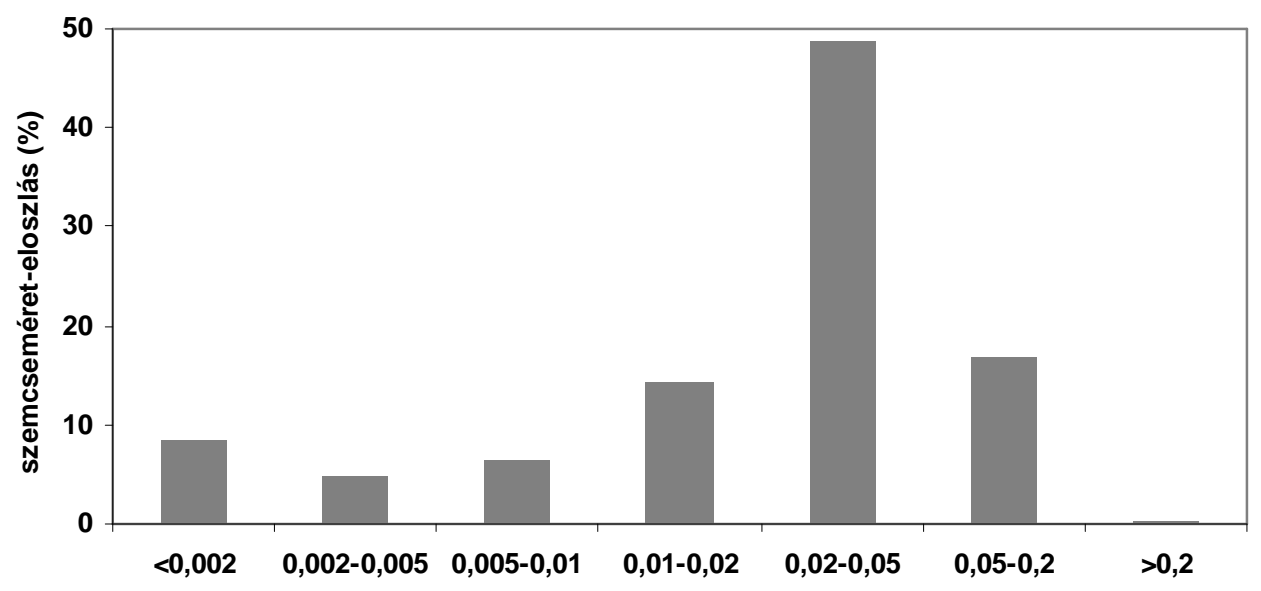

48. ábra. A C szintek jellemzö szemcse-eloszlása (3/C szint alapján) 


\subsubsection{A talajtulajdonságok változása a 20-21. században}

Az időbeli változások elemzéséhez mérési adatok alapján (1949-2008) csak a 3. mintavételi hely esetében nyílhat lehetőség (49. ábra), hiszen 1949-ben mérés a másik két, általunk vizsgált pontban nem történt. A talajok morfológiája, a mért talajvizsgálati paraméterek, illetve a teljes ÉNy-DK irányú mélyedés domborzati viszonyai alapján lehetőség nyílhat a többi mintavételi hely talajtípusának leírására is.

A 3. mintavételi helyen az adatok a feltalaj pH-jának és sótartalmának csökkenését mutatják az elmúlt közel 50 évben. A 0-30 cm-ig vett átlagmintában mért sókoncentráció 1949-ben 0,06 \% volt, mely akkor még elérte a gyengén szoloncsákos sófelhalmozódás kategória alsó határát. Vélhetően a magas $\mathrm{pH}$, a sótartalom-adatok, valamint a morfológiai bélyegek alapján sorolódott e talaj a II. osztályú, erősebben szikes kategóriába a Kreybig térképeken. A Ca-karbonát tartalom az elmúlt 50 év alatt nem változott a talajfelszín közelében. A Na-karbonát esetében csak csekély csökkenés tapasztalható. Humusztartalommérés nem volt 1949-ben, viszont a 2008-as adatok a felszín közelében igen jelentős mennyiségű szerves anyagot mutatnak.

$\mathrm{pH}$

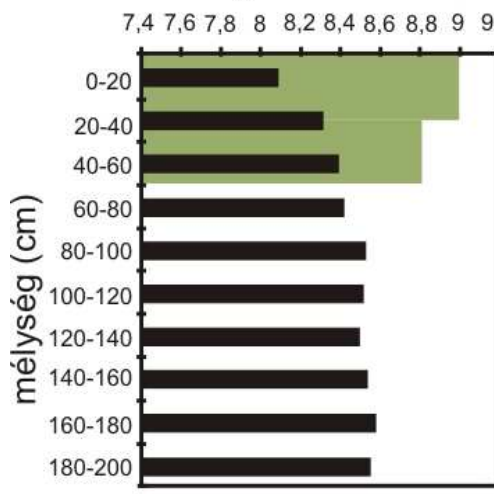

fenolftalein lúgosság (\%)

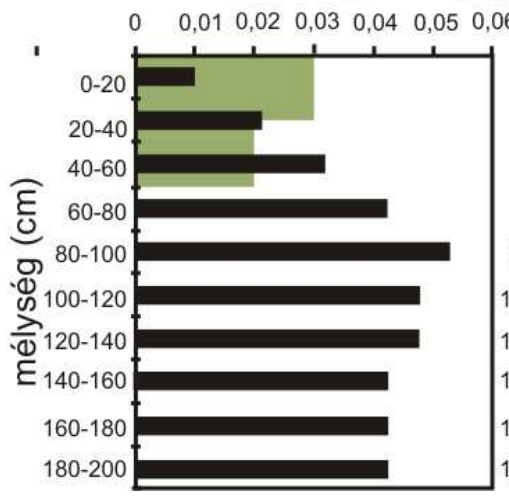

sótartalom (\%)

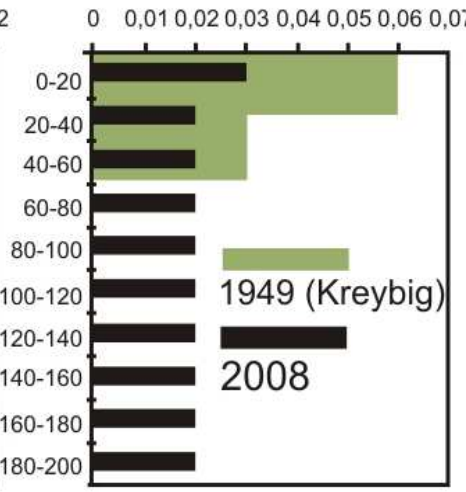

$\mathrm{CaCO}_{3}(\%)$

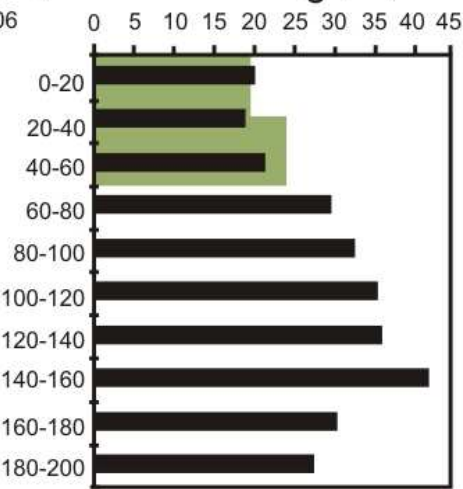

49. ábra. A pH, a sótartalom, a Ca-karbonát és a fenolftalein-lúgosság változása 1949 és 2008 között 
Az összehasonlított eredmények a talajvízszint-csökkenés következtében dominánssá váló kilúgozódás és a sztyeppesedés folyamatát mutatják. Az elmúlt évtizedekben csökkent a pH, a szikesedésre jellemző vízben oldható sók a mélyebb szintek felé mosódtak. A $\mathrm{Na}_{2} \mathrm{CO}_{3}$ (szóda) mennyisége ma 80-100 cm-en mutat maximumot, de sehol sem haladja meg a $0,06 \%$-ot.

A mai talajállapotok alapján a következő megállapítások tehetőek:

- A vizsgált buckavonulatok közötti mélyedésben a három helyen, szegmens mentén mélyített furatok talajvizsgálati eredményei ma egyik esetben sem mutatnak szikes jelleget. Elképzelhető, hogy a mélyedés közepén és délkeleti részében fekvő 2-es és 3-as mintavételi pontban fél évszázada a nagyobb vízhatás és a talajvíz Na-tartalmának felhalmozódása hozzájárulhattak szikes talajok kialakulásához. A nátrium-sók jelenlétét az 1949-es laboratóriumi mérési eredmények támasztják alá.

- Az 1. mintavételi pont talaja vélhetően (mélyben sós) réti csernozjom lehetett. Ennek bizonyítékai magasabb fekvése, a jelentős mélységü A szint és annak szerkezete, valamint a mélyben mutatkozó vízhatás nyomai. Sótartalomra vonatkoztatott megelőző adat nincsen, a mélyben sós jelleget csak feltételezni lehet.

- A 2. mintavételi hely környékének vízborítottságát már a Kreybig-térkép is jelezte, valamint a terepen is jól beazonosíthatóan látszik a környező területekhez képest mélyebb fekvése (50. ábra). A mintavétel e lokális depresszió pereme közelében történt. A talajszintek elkülönülése éles, a vízhatások nyoma a felszínhez viszonylag közel megjelenik, és sokkal magasabban a szelvényben, mint a másik két furat esetén. Vélhetően egy szolonyeces réti talaj, vagy akár egy réti szolonyec talaj lehetett a csatornázások előtt (51. ábra). Mivel sótartalomra vonatkozóan nem áll rendelkezésre korábbi adat, így még akár ennél jelentősebb sófelhalmozódás is elképzelhetőnek tűnhet. A szikes jelleget támaszthatja alá a sekélyebb A szint és az A-B szint éles átmenete, valamint a mikrodomborzat (a depresszió legmélyebb területén réti talaj lenne várható).

- A 3. mintavételi hely habár ma a morfológiai bélyegeket tekintve réti csernozjomnak írható le, az e talajtípushoz kötődő folyamatok nem jellemzik azt. A megelőző 1949-es adatok alapján réti szolonyec talaj lehetett ez a vízrendezések előtt, melyeket az akkori szelvényleírások és sótartalmak bizonyítanak. Az 1949-ben 130 cm-en megfigyelt talajvízszint felette van a kritikus talajvízszintnek, tehát elképzelhető, hogy sófelhalmozódás a szelvényben létrejöhetett (1949-ben 0-30 cm-ig 0,06\%, 30-60 cm-ig 0,03\% vízben oldható sótartalom jellemezte). A talajvíz tükör kritikus talajvízszint alá 
csökkenésével a talajoldat sótartalma már nem gyarapítja a szelvény sótartalmát, jelenleg a csapadék hatására a kilúgzási folyamatok dominálnak, melyek a talaj sótartalmának csökkenését magyarázhatják. Ezen folyamatok ismeretében a talajtípust inkább egy sztyeppesedő réti szolonyec talajként határozhatjuk meg.

- A jelentős pH - ma és a csatornázás elött is - mindhárom mintavételi hely esetében a Ca-karbonát és a szóda lúgos hidrolízisére vezethető vissza.

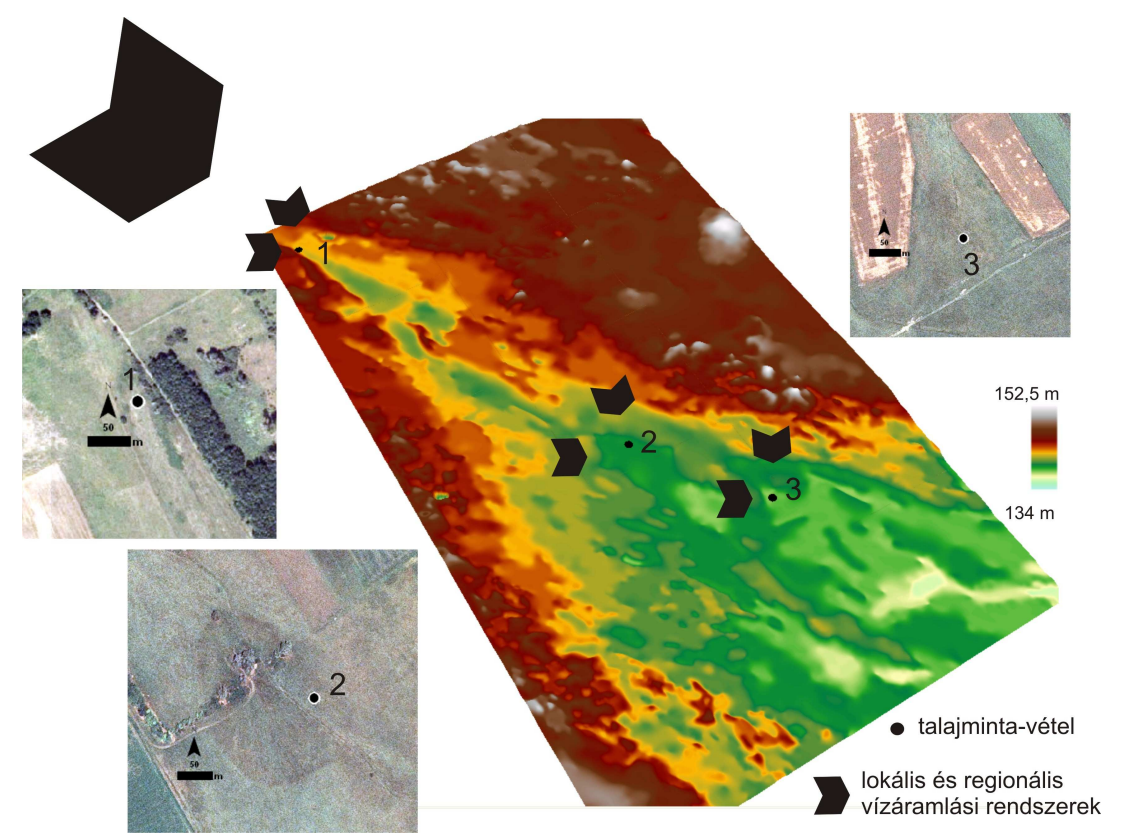

50. ábra. A mintavételi pontok elhelyezkedése és a lokális és regionális vízáramlási rendszerek hatása

a.

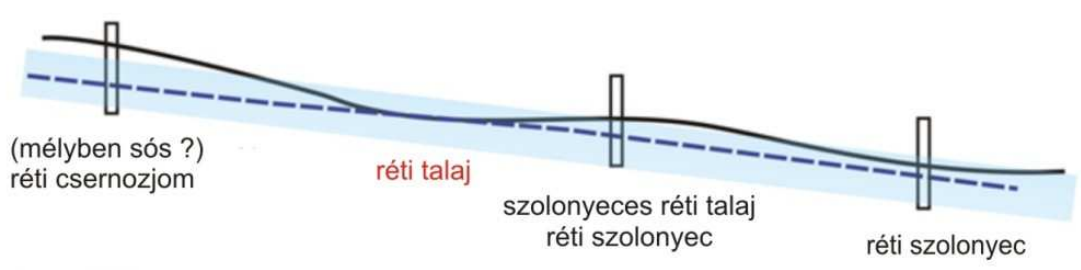

b.

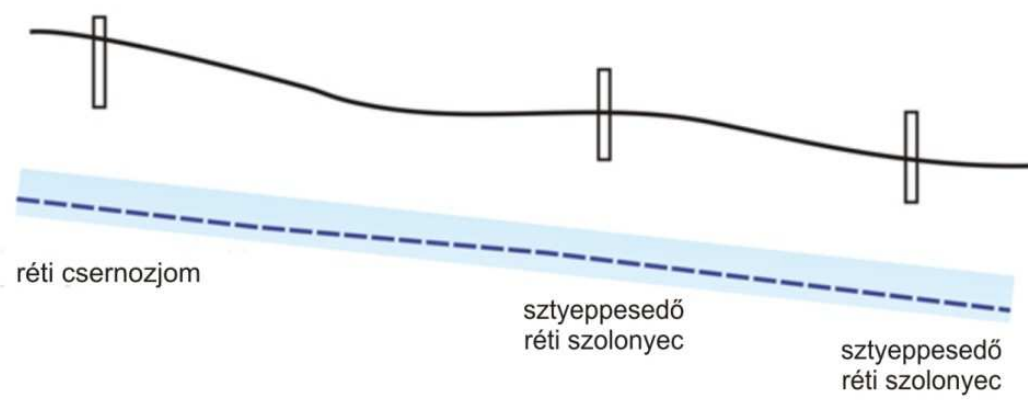

51. ábra. A talajviszonyok sematikus ábrázolása a mintaterületen a. a talajvizszint-csökkenést megelözö feltételezhetö állapot b. aktuális állapot

(a szaggatott vonal a talajvíz szintjét, a kék sáv a talajvíz ingadozási zónáját jelöli) 


\subsubsection{Aktuális fajkészlet és az élőhelyek változásai a 20.-21. században}

A Dorozsma-Majsai-homokhátról először leírt lokális láprétfö-szikalj mintázat (Deák 2006) - a homokhátsági deflációs laposok, szélbarázdák lokális élőhelymintázata az Illancs homoki tája és a Bácskai-löszhát lösztájának határánál található mintaterületeken is bizonyítható. A vizsgált mintaterület mélyedéseiben azonosíthatók a szikes és lápi élőhelyek maradványai a lokális depressziókban, de a talajvízszint-süllyedés következtében ezek az élőhelyek sokszor homoki sztyepprétekbe alakultak át vagy a fenti élőhelytípusok sztyeppesedő változatai jelentek meg.

A vizsgált terület ÉNy-i része ma homoki sztyepprét kategóriába sorolható (52. ábra). Domináns fajok a csenkeszek (föleg a sovány csenkesz (Festuca pseudovina)), a terület egykori üde jellegét mára már csak a vízimenta (Mentha aquatica) és a kötökáka (Scirpus lacutris ssp. tabernaemontani) mutatja. A száraz sztyeppréti fajok jelentős menynyiségben fordulnak elö. A nádtippan (Calamagrostis epigeios), nagy csalán (Urtica dioica), bókoló bogáncs (Carduus nutans), illetve selyemkóró (Asclepias syriaca) a terület zavarását jelzik: valószínűsítve, hogy a terület ezen részét valamikor felszántották.

A terület mellett húzódó út felé közeledve, a mezsgye felé egyre természetközelibb vegetáció figyelhető meg (52. ábra 1é), a területen itt fordul elő egyedül védett faj, a homoki fátyolvirág (Gypsophila fastigiata L. subsp. arenaria). Ez a jobb természetességü élőhelyfolt segíti a kiszáradó vizes élőhelyek regenerációját (lásd a 10. melléklet 1-es jelzéssel ellátott terület nagyobb fajgazdagságát). Szemmel láthatóan elkülönül ez a két rész a nyári időszakban (53. ábra): a mezsgye és környéke sokkal zöldebb, a nagyobb arányú tarackbúza (Agropyron repens), farkas kutyatej (Euphorbia cyparissias) és tejoltó galaj (Galium verum) miatt, ám ugyanitt a szúrós növények (lásd bókoló bogáncs (Carduus nutans), tövises iglice (Ononis spinosa) aránya sokkal kisebb.

A területen érdemes külön hangsúlyt fektetni a 2. foltként jelzett kékperjés láprét foltra (54. ábra), ami egy vályogvető gödör mélyedésében, közvetlenül a csatornaparton található. Fennmaradásának oka többek között a mikro-domborzati különbségekben keresendő. A terület üde jellegét kezdi elveszteni, galagonyásodik, és egyre inkább homoki sztyeppréti fajok vándorolnak bele (tejoltó galaj (Galium verum), fehér mécsvirág (Melandrium album), mezei cickafark (Achillea collina)). A terület egykori üde voltát a kékperjéstől É-ra található fehér füzek (Salix alba) is jelzik. 


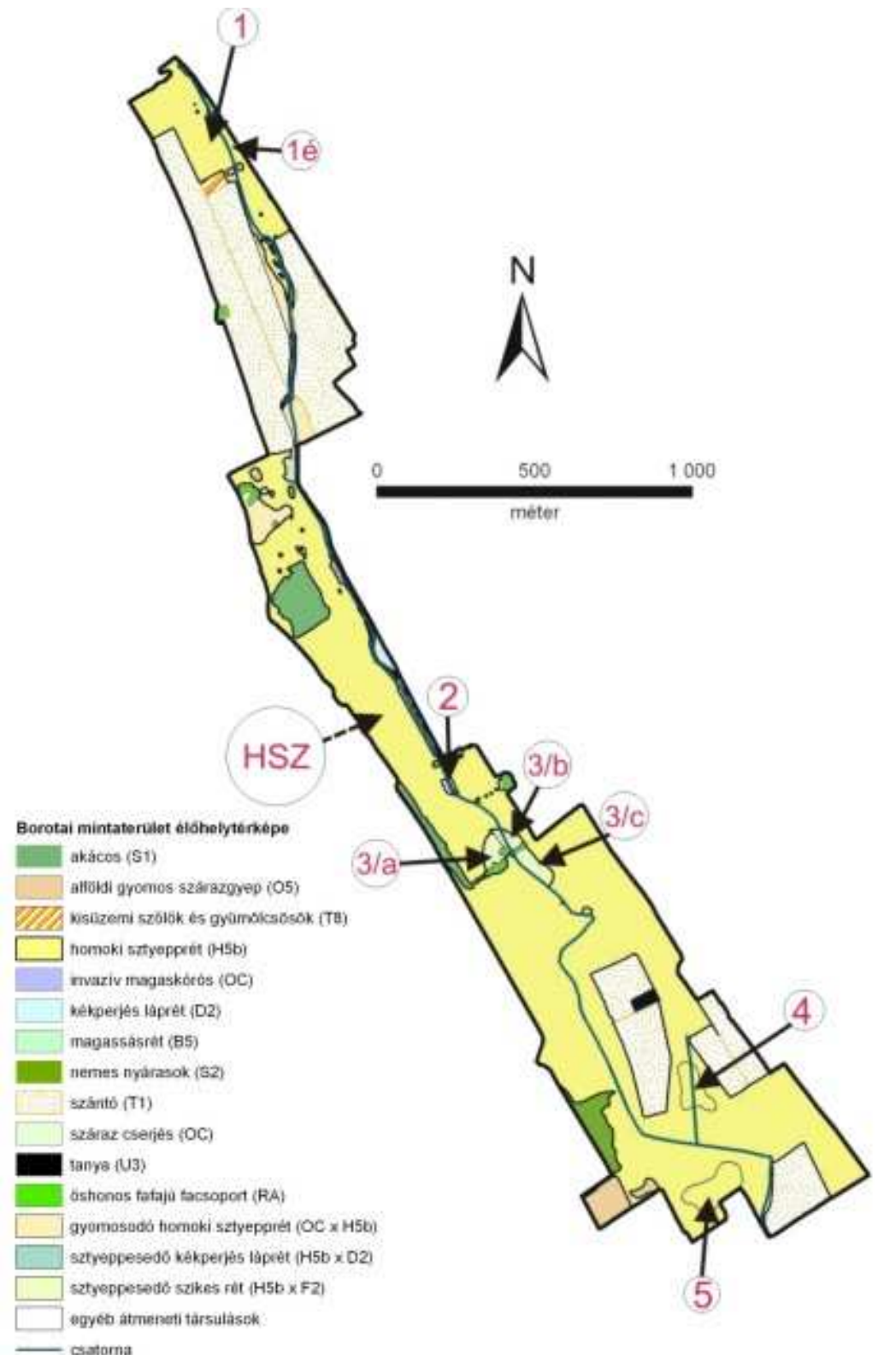

52. ábra. A borotai mintaterület élöhelytérképe

(a számokhoz tartozó élőhelyek fajlistáját a 10. melléklet tartalmazza)

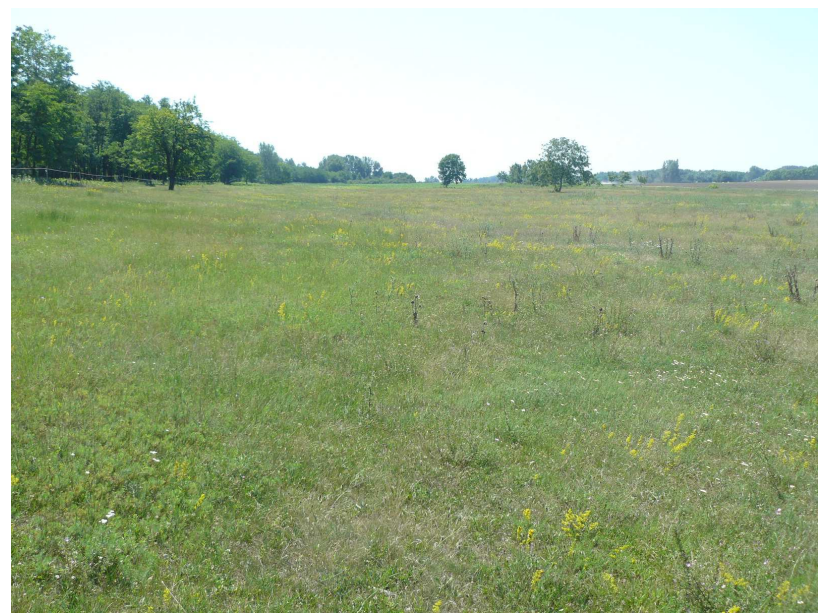

53. ábra. A mezsgye irányában (kép bal oldala) egyre jobb természetességü homoki sztyepprét 
Az eddig bemutatott adatok alapján az látszik, hogy a terület északi része (a Kreybig térképen bejelölt északabbi szikes folt helyén (44/b. ábra)) ma egyetlen „maradványfaj” sem mutatkozik, így vélhetően az nem volt szikes. Ha mégis szikes volt, az átalakulás olyan mértékü, hogy azt egyetlen szikes faj sem „élte túl”.

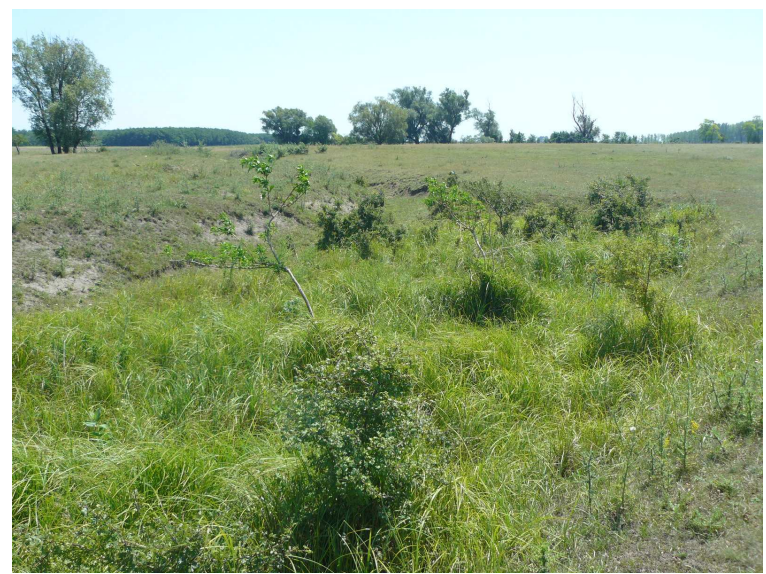

54. ábra. A láprét-folt tavasszal (2. folt)

A Kreybig-térképen vízzel borított területként jelölt mélyedésben egykori üdébb, szikes rét maradványaira bukkanhatunk (52. ábra 3/a, b, c ). A sziki szittyó (Juncus gerardii), a sziki kerep (Lotus glaber), a sziki cickafark (Achillea asplenifolia) jelenléte egy egykori szikes rét vegetációra, a vízi menta (Mentha aquatica) pedig üde rétre utal. A 3/b-vel jelzett részen jelentősebb a nádképü csenkesz (Festuca arundinaceae) aránya, amelyből valószínüsíthető, hogy egykor nádképű csenkeszes szikes rét lehetett ezen a részen, amely egyre inkább kiszárad, szinte teljesen elsztyeppesedett, a homoki sztyepprét fajok aránya nagy. A csatorna aljában jelentős mennyiségü sziki kerep (Lotus glaber) fordul elő. A 3/c-vel jelzett foltban a nádképü csenkesz (Festuca arundinacea) aránya jelentősebb, amely azt mutatja, hogy e terület kevésbé száraz, mint a körülötte lévők, köszönhetően a mélyebb fekvésének.

A terület DK-i részén, a 4-essel jelölt foltban szintén megfigyelhetőek az egykori szikes rét jellemző növényeinek maradványai (sziki szittyó (Juncus gerardii), sziki kerep (Lotus glaber), sziki cickafark (Achillea asplenifolia), valamint jelentősebb kékperje (Molinia Hungarica) állomány is mutatkozik. A folton áthúzódó mellékcsatornában a kékperje mennyisége még jelentősebb. Ezen a területen is a sztyeppesedés nyomai szembetünők: a homoki sztyepprétfajok alkotják az állomány többi részét. Jelen állapotában ez a folt az elsztyeppesedett kékperjés láprét kategóriába sorolható leginkább, de érdekes módon hordozza a szikes rét fajait is. A 3. talajmintavétel is ebben a foltban történt. A növényzet tehát egyértelmüen bizonyítja a terület eredeti üde jellegét, azonban az eredeti társulásokra nagy bizonyossággal nehéz következtetni. 
Az 5-össel jelölt folt a terület legmélyebb részen fekszik, habár sokkal kevésbé érzödik rajta, hogy valaha nedves, üde rét lett volna. Jelentős arányú a sovány csenkesz (Festuca pseudovina), elöfordul tarackbúza (Agropyron repens), valamint pár tő kékperje (Molinia arundinacea), kevés sziki kerep (Lotus glaber) is található benne. E folt azonban így a terület legnagyobb részét alkotó homoki sztyepprét kategóriába sorolható.A terület többi részén (az 52. ábrán sárgával jelölt területek) homoki sztyepprétek találhatóak, melynek természetessége közepes. A birkalegeltetésnek köszönhetően sok szúrós növény fordul elő (bókoló bogáncs (Carduus nutans), tövises iglice (Ononis spinosa)) (55. ábra), és a fajszám is sokkal alacsonyabb (10. melléklet). Az állatoknak köszönhetően a legeltetett részeken alig fordulnak elő invazív fajok, viszont a terület északi részén, a csatorna környékén terjed a magas aranyvessző (Salidago giganthea), a kökény (Prunus spinosa) és a selyemkóró (Asclepias syriaca) a legeltetés hiánya miatt.

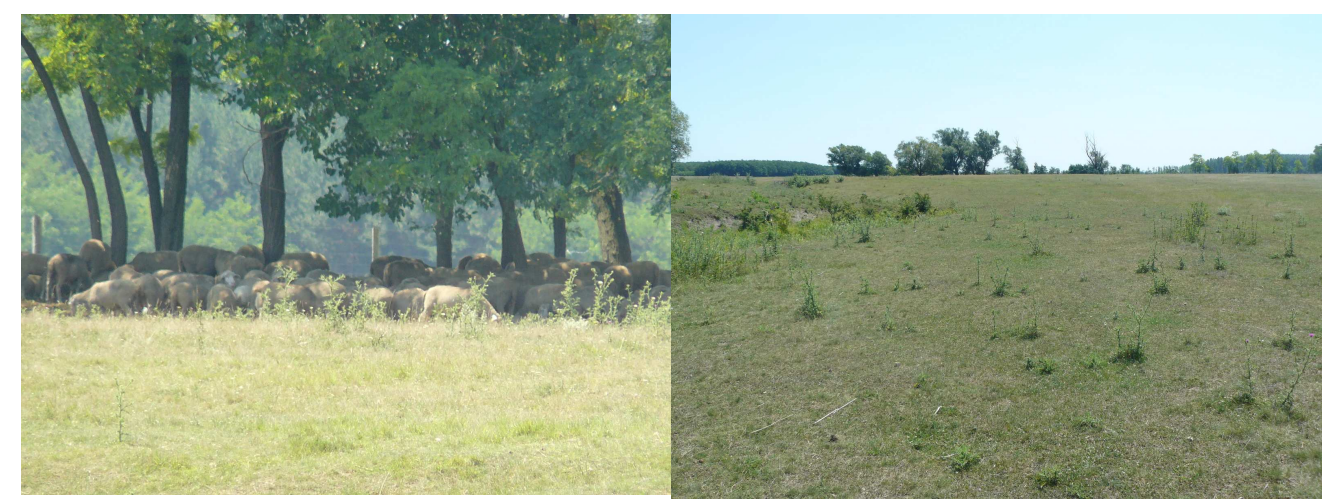

55. ábra. A juhlegeltetés hatása

Általánosságban elmondható a területről, hogy északi része felé haladva a lápi élőhelyek maradványai nagyobb gyakorisággal jelennek meg, jelezvén, hogy az Illancs központi része felöl érkező talajvizek egykoron jelentős hatást gyakorolhattak a terület vegetációmintázatára. A lápi jellegü élöhelyek a terület középső részének északi felén őrződtek meg leginkább magassásrétek és kiszáradó kékperjés láprétek formájában. A talajvízszint süllyedését jelzi a kékperjés rétek galagonyásodása is, valamint az, hogy a terület középső részén több helyen eltolódtak a vegetációs zónák: a kékperjés rétek helyét a deflációs mélyedésekben a homoki sztyepprétek vették át, míg a kékperjés a területet metsző csatornába húzódott le (56. ábra).

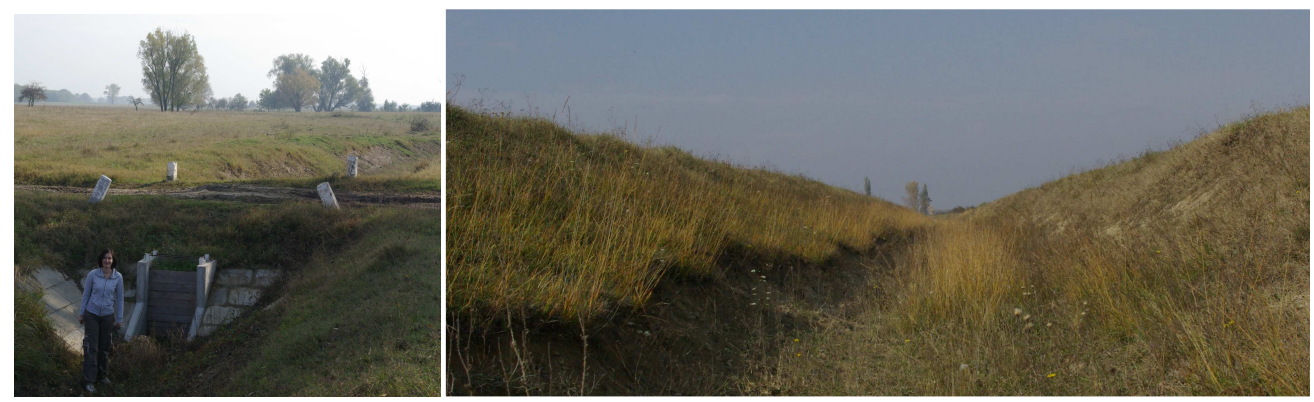

56. ábra. A területet metszö mintegy 2 méter mély csatorna 2008 öszén 


\section{4. Megállapítások a talaj és a vegetáció tekintetében a vizsgált mintaterületen}

A talaj és vegetáció vizsgálata tükrében elmondható, hogy a Kreybig térképen bejelölt két szikes folt közül az É-i valószínüleg soha sem volt szikes terület. Sem a talajtani paraméterek, sem a vegetáció mintázata nem utal egykori szikes körülményekre: csak a terület üde jellegére találunk bizonyítékot. A terület egykori jelentős vízborítását az átlagosan 1,5 méter mély csatorna is jelzi. A vízhatások nyomát mindhárom talajszelvényben a vas és mangánfoltok mutatják. Feltételezhető, mivel a Kreybig-felvételezés idején korlátozott számban nyílt lehetőség a talajok mintázására, így előfordulhatott, hogy a fekvés, a növényzet és a vízborítás hasonlóságai miatt a terület különböző részeit hasonló jellegünek ítélték és írták le.A mintaterület déli részén ma szikesedésre utaló bélyegeket nem lehet találni. A 3. mintavételi helyen az 1949-es vizsgálatok Na-sók felhalmozódását mutatták ki, melyek valóban szikes talajok meglétét feltételezték. A vízhatások nyomait ma is azonosítani lehet mind a két vizsgált pontban. A botanikai vizsgálatok által azonosított „maradványfajok" a terület egykori szikes jellegét támasztják alá. Ezen üde élőhelyeket ma az egykori szikes rétek kiszáradt, sztyeppesedő, jellegtelenedő változatai képviselik.

Az elmúlt évtizedek drasztikus talajvízszint-csökkenése nyomán teljesen más folyamatok váltak uralkodóvá a területen, mint amelyek a vízrendezések előtt e tájat meghatározták. Az egykor üde rétek dominálta mélyedés talajai teljesen mentesültek a talajvíz hatása alól (viszonylag rövid idő alatt). Ennek eredményeképpen a réties jelleg és a szikesedés helyett ma a kilúgozódás és a sztyeppesedés dominál. A gyors változások következtében a talajok morfológiája még hordozza az egykori talajtípusok jellemzőit (hiszen az ilyen jellegü átalakulásokhoz több száz (esetleg ezer) év is szükséges), viszont teljesen más folyamatok jellemzik ma a szelvényeket, melyek együttes értékelése megnehezíti azok talajtani besorolását. A hazai genetikus talajosztályozás szerint a sztyeppesedő réti szolonyechez állnak a legközelebb az egykor szikes szelvények, de megelőző múltbéli pontos mérések hiányában nehézkes a besorolásuk, jelenlegi jellemzőik alapján (vastag A szint, mélyen vaskiválások) a réti csernozjomokkal mutatnak hasonlóságot. 


\section{A TÁJI ÉRZÉKENYSÉG ÉRTÉKELÉSE AZ ILLANCSON TÉRINFORMATI- KAI ESZKÖZÖKKEL}

\subsection{A spektrális indexek alkalmazása a táji környezet értékelésében}

A földrajzi információs rendszerek adta lehetőségekkel a térbeli információnyerés jelentősen felgyorsult, hatékonysága meghaladja a hagyományos módszerekkel történő térképi értékeléseket. Léptéke lehetőséget ad lokális, regionális és globális vizsgálatokra is, valamint segítségükkel olyan területek is megfigyelhetőek, amelyeket hagyományos vizsgálati módszerekkel veszélyességük vagy megközelíthetetlenségük miatt tanulmányozni nem lehetett. A távérzékelési adatok alapján elvégzett tér- és időbeli elemzésekkel különböző jelenségekre, körülményekre, összefüggésekre, trendekre vonatkozó kérdéseinkre kaphatunk választ (4. táblázat).

4. táblázat. A tájváltozás térinformatikai vizsgálatainak lehetőségei (Kennedy et al. 2009)

\begin{tabular}{|c|c|}
\hline $\begin{array}{c}\text { Vizsgált tulajdonságok, } \\
\text { indikátorok }\end{array}$ & A vizsgált folyamat, veszély \\
\hline $\begin{array}{c}\text { A vonatkozó felszínborítási kategória } \\
\text { foltjainak méretének (kiterjedésének) és } \\
\text { alakjának vizsgálata }\end{array}$ & Növények terjeszkedése, gap-ek betöltése, erózió \\
\hline $\begin{array}{c}\text { A keskeny, vonalas elemek jellegének, } \\
\text { szélességének változása }\end{array}$ & $\begin{array}{c}\text { Utak/útvonalak forgalmának hatása, árvíz ese- } \\
\text { mények a folyó menti vegetációra, a szárazföldi } \\
\text { és a partvidéki vízi vegetáció dinamikája }\end{array}$ \\
\hline $\begin{array}{c}\text { A felszínfedettség illetve a fajösszetétel } \\
\text { lassú változása }\end{array}$ & $\begin{array}{c}\text { Szukcesszió, versengés, eutrofizáció, idegenho- } \\
\text { nos növényekkel való betelepülés }\end{array}$ \\
\hline Hirtelen változások a felszínborításban & Zavarás, humán térhódítás, táj-menedzsment \\
\hline $\begin{array}{c}\text { Egyes felszínborítási típusok állapotá- } \\
\text { ban történő lassú változások }\end{array}$ & $\begin{array}{c}\text { Klímával kapcsolatos változások a vegetáció } \\
\text { produktivitásában, a rovarok vagy más betegsé- } \\
\text { gek miatti erdőpusztulások lassú folyamata, vál- } \\
\text { tozások a vízháztartásban }\end{array}$ \\
\hline $\begin{array}{c}\text { A szezonális folyamatok ütemezésében } \\
\text { és kiterjedésében történő változások }\end{array}$ & Hóborítás dinamikája, vegetációs fenológia \\
\hline
\end{tabular}

Az 1970-es években a felszín spektrális tulajdonságai alapján kezdtek kifejleszteni radiometriai mérőszámokat (indexeket) azzal a céllal, hogy minél pontosabb kvantitatív kapcsolat jöjjön létre a távérzékelési értékek és a valóság között. Az egyik ilyen index csoport a vegetációs indexek, melyek a látható fény (általában a vörös) és az infravörös (általában a közeli infravörös) hullámhossztartomány között mérhető, a növényzet klorofilltartalmán és levélszerkezetén alapuló kontrasztos reflektancia-különbségre építenek. Mivel egy vegetációs index arányos az olyan biofizikai paraméterek mérhető értékeivel, mint a $\mathrm{LAI}^{6}, \mathrm{GVF}^{7}$,

\footnotetext{
${ }^{6}$ Leaf Area Index (Levélfelületi index)

${ }^{7}$ Green Vegetation Fraction (Zöldfelület arány)
} 
$\mathrm{NPP}^{8}, \mathrm{APAR}^{9}$, így általánosan használhatóak a vegetáció mennyiségének és minőségének vizsgálatára (Ji - Peters, 2006). Egy ideális vegetációs indexnek rendkívül érzékenynek kell lennie a biofizikai paraméterekre, ellentétben a különböző forrásokból keletkező képi zajokkal, mint a légkör, a talaj stb. Bevezetésüknél fö cél volt a globális és regionális vizsgálatokat megalapozó, hosszú időtartamú stabil adatsorok kialakítása. Ezt a feladatot sikeresen teljesítették is, hiszen valamennyi régi (AVHRR, LANDSAT, SPOT) és új szenzor (pl. MODIS, IKONOS) felvételei bevonhatók a vizsgálatokba.

Az elmúlt közel 40 évben számos vegetációs indexet dolgoztak ki, melyek általában két-három spektrális csatorna alapján számítódnak. A legismertebbek ezek közül az egyszerü viszonyszám SR (Jordan 1969), a normalizált vegetációs index (NDVI) (Rouse et al. 1974), a talajjal korrigált vegetációs index (SAVI) (Huete 1988), transzformált SAVI (TSAVI) (Baret - Guyot 1991), a légkörrel korrigált vegetációs index (ARVI) (Kaufman Tanré 1992), a talajjal és légkörrel korrigált vegetációs index (SARVI) (Kaufmann - Tanré 1992), a módosított SAVI (MSAVI) (Qi et al. 1994), javított/bővített vegetációs index (EVI) (Huete et al. 1994), optimalizált SAVI (OSAVI) (Rondeaux et al. 1996), módosított normalizált vegetációs index (MNDVI) (Liu - Huete 1995), a generalizált SAVI (GESAVI) (Gilabert et al. 2002), a módosított nem lineáris vegetációs index (MNLI) (Gong et al. 2003), linearizált vegetációs index (LVI) (Ünsalan - Boyer 2004). Sajátos a TM, ETM+ szenzorokra kifejlesztett Tasseled Cap kompozitindex (Kauth - Thomas 1976), mely hat hullámhossz-tartomány értékeinek súlyozásával számol.

A másik tájváltozás-vizsgálatokban alkalmazott indexcsoport a nedvességi indexek, melyek segítségével víztartalomra, vízborításra vonatkozó információkat nyerhetünk a környezetre vonatkozóan. Ezek közül fontosabbak a talaj-nedvességi index (SWI) (Basist et al. 1998), topográfiai nedvességi index (TWI) (Beven - Kirkby 1979) a már említett tasseled cap index harmadik rétege a nedvességi index (TCW), a normalizált nedvességkülönbség index (NDMI) (Hardisky et al. 1983), talajnedvesség változatosság index (SWVI) (Lacava et al. 2005), a növényi vízstressz index (CWSI) (Jackson 1982), Water Mask index (Dobson é.n.).

Sokrétü alkalmazásaik szerte a világon a terménybecsléstöl kezdve a közegészségügyi- és tájdegradációs vizsgálatokon át a bio- és geokémiai modellekig sorolhatók. Magyarországon is egyre inkább szaporodnak a multi- és hiperspektrális távérzékelés nyújtotta lehetőségeket kihasználó kutatások: például a szikes talajok tekintetében (Tóth et al.

\footnotetext{
${ }^{8}$ Net Primary Productivity (Nettó primer produkció)

9 Absorbed Photosynthetically Active Radiation (Elnyelt fotoszintetikusan aktív sugárzás)
} 
1991, Burai - Tamás 2005), invazív növények terjedésének vizsgálatában (Kardeván et al. 2005), táji vizsgálatokban (Kovács et al. 2004, Kristóf 2005, Molnár et al. 2007, Szatmári 2006, Kovács 2009a), területhasználat és beépítettség térképezésében (Kovács 2009b), az erdészeti alkalmazások tekintetében (Márkus et al. 2000), mezőgazdasági vonatkozásokban (Csornai 2001, Martinovich et al. 2003, Bognár 2004, Tamás 2009), városi területek vizsgálatában (Gábor et al. 2006., Jung 2005, Mucsi et al. 2007).

A szárazodás hatását Duna-Tisza közi viszonylatban spektrális indexek alkalmazásával Kovács (2006) vizsgálta. Hosszú időtartamú, LANDSAT TM (ETM+) müholdkép alapú adatsoron elemezte a Duna-menti szikes tavak kiterjedésének változását, változékonyságát. A vizes élőhelyeket az NDVI, TCW és WaterMask indexeredmények összetett lekérdezésével határolta le. A vizes, vizenyős és száraz területek térbeli-időbeli elkülönítésével határozta meg a szárazodás mértékét. Kovács (2006) kutatásaiban továbbá AVHRR és MODIS felvételek 15 éves NDVI vegetációs index adatsora alapján Duna-Tisza közi erdők és gyepek veszélyeztetettségét értékelte a szárazodás által. Arra a kérdésre kereste a választ, hogy a több mint egy évtized alatt milyen változások ismerhetők fel a biogén tényező jellemzőiben és van-e összefüggés az eltérésekben. Trend jellegü csökkenést sikerült kimutatnia az NDVI átlagokban. Összesített térbeli elemzése szerint 1992-2001 között a Duna-Tisza köze területének 1/3-án veszélyeztetett a vegetáció az aridifikáció által.

A regionális elemzésekben megfigyelt hőmérséklet-emelkedési és csapadékcsökkenési, valamint talajnedvesség- és talajvízcsökkenési trendek közvetlenül befolyásolják a Duna-Tisza köze szélerózió-veszélyeztetettségét is. Szatmári (2006) távérzékelt felvételek alapján szélerózió-veszélyeztetettségi térképet szerkesztett a Duna-Tisza közére. Komplex értékelésében spektrális indexeket is alkalmazott (NDVI, SBI (brightness), SGI (greeness), SWI (wetness)).

A folyamatos távérzékelt adatok egyre jobb elérhetőségével és javuló felbontásával egyre több tanulmány jelenik meg, mely a vegetáció periodikus változásainak kapcsolatát vizsgálja a klímaelemekkel (Ahl et al. 2006, Evrendilek - Gulbeyaz 2008, Huete et al. 2006, Kaurivi et al 2003, Wallace - Thomas 2008, Waring et al. 2006, Zhanga et al. 2003). Vegetációs index adatsorok klimatikus vizsgálatával Magyarországon Kern és munkatársai (2007) foglalkoztak. Kutatásukban 1981-2001 közötti NOAA NDVI 10 napos kompozit adatsort, valamint havi átlagos hőmérsékleti és havi csapadékösszeg adatokat használtak fel a fenológia és az éghajlat közötti kapcsolat tanulmányozására. Vizsgálataikban rámutattak a biomassza-produkció és a klíma közötti szoros összefüggésekre, mely szerint országos szinten az évi átlagos NDVI szoros kapcsolatban áll az éves átlaghőmérséklettel. Ki- 
mutatták, hogy nem csak a csapadék mennysiége, de időbeli eloszlása is jelentős hatással van az NDVI éves menetére és maximális értékére.

E megállapítások alapján a dolgozatban vizsgált kistájon tapasztalt jelentős vízhiány, és a talajvízszint igen jelentős mélysége a növényzet fokozott érzékenységét feltételezi a térségben, hiszen a növényzet a rossz talajadottságok következtében elviekben még jelentősebben függhet a csapadéktól, mint a környező tájakon. A víz, mint szük keresztmetszet jelenik meg az Illancson. A következőkben a csapadék és a biomassza-aktivitás kapcsolatát értékelem vegetációs indexek segítségével, e kérdések megválaszolására. A csapadék tekintetében bizonyuló érzékenység és a talajvízszint-süllyedés mértéke együttesen a kistáj 'klíma-érzékenységét' támaszthatják alá.

\subsection{A térinformatikai elemzéshez felhasznált adatok, az előfeldolgozás és az elemzés módszerei, valamint a vizsgált mintaterületek}

2000 óta érhetőek el folyamatos globális vegetációs index adatok a Terra (és az Aqua) műhold MODIS ${ }^{10}$ szenzorának adatai alapján. A vizsgálatokhoz MOD13Q1 adatokat használtam fel (Huete et al. 1999), melyek NDVI, EVI, valamint pixel minőség információkat tartalmaznak. A vegetációs indexek adatokat radiometrikus és atmoszférikus korrekciók eredményeképpen kapott felszíni reflektancia értékekből számítják (Huete et al 2002).

A Normalizált Vegetációs index (NDVI) a legáltalánosabban használt eszköz a nettó biomassza mennyiség becslésére. Ez az index a zöld biomassza mennyiségének, a klorofilltartalomnak, valamint a levélfelületi vízstressz változását jelzi. Az index a közeli infravörös (NIR) és a vörös tartomány $(\mathrm{R})$ pixelértékeit veszi figyelembe, és a következő módon számolható:

$$
N D V I=\left[\frac{N I R-R}{N I R+R}\right]
$$

A számítás alapja az, hogy a növények levelének klorofill pigmentjei a látható fény

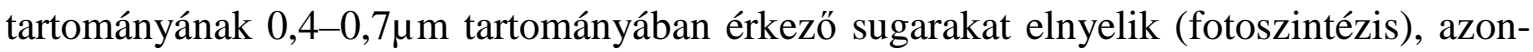
ban a levelek sejtszerkezete pedig másrészröl visszaveri a közeli infravörös tartományban érkező sugarakat $(0,7-1,1 \mu \mathrm{m})$. Az indexszámítás eredményéül kapott értékek -1 (nem eutróf jellegü vízfelület, kopár szikla) és +1 (dús erdő) között változnak.

Az NDVI továbbfejlesztett verziója az EVI index, amelyben a vörös és a közeli infravörös sáv mellett szerepel a kék sáv is. A kék sáv érzékeny az atmoszférikus körülményekre, gyakran használják atmoszférikus korrekciókra. Az EVI index alkalmazhatósága

\footnotetext{
${ }^{10}$ Moderate Resolution Image Spectroradiometer
} 
tekintetében abban különbözik az NDVI-től, hogy kiküszöböli az atmoszférából, illetve a különböző talajtípusokból eredő hibákat. Az EVI index számítása (Liu - Huete 1995):

$$
E V I=2,5 * \frac{(N I R-R)}{\left(L+N I R+C_{1} R-C_{2} B\right)}
$$

ahol a megfelelő sávok reflektancia-értékei a $N I R, R, B ; L$ egy korrekciós érték, valamint a $C_{1}, C_{2}$ pedig súlyozó tényezők, azt fejezik ki, hogy a vörös sáv aeroszol korrekciójában mekkora szerepe van a kék sávnak. A MODIS EVI algoritmusban alkalmazott koefficiens értékek $L=1, C_{1}=6, C_{2}=7,5$, és $G=2,5$ (Jiang et al. 2008). A hiányzó vagy rossz minőségü adatok a felvételezési hibák és a felvételezés során meghatározó légköri körülményeknek köszönhetően (felhőborítottság, atmoszféra összetétele stb.) jelentősen befolyásolhatják a képi adatok minőségét. Ezeknek kiküszöbölésére használják az $\mathrm{MVC}^{11}$ technikát. Az elemzés során használt 16 napos kompozit képek figyelembe veszik az egyes mérések minőségét, és a 16 nap alatt mért vegetációs index értékek maximumát tárolják (Huete et al. 2002). A MODIS NDVI és EVI kompozit képek ingyenesen elérhetőek és letölthetőek a Land Processes Distributed Active Archive Centre (LP DAAC) honlapjáról.

Mivel az adatok HDF-EOS formátumban érhetőek el, ezért a vizsgálatokban a HegTool programot (HDF-EOS 2010) használtam a Geotiff-be való konverzióhoz, mely a GIS alkalmazások általános formátuma. A terjedelmes adatmennyiség feldolgozásához paraméterfájlokat alkalmaztam (11. melléklet), melyben előre definiáltam a konverzió adatait (kivágás koordinátái, a kiválasztott sáv, a vetületi rendszer, a pixelméret, a bemeneti és a kimeneti file neve), majd egy resample.bat file-ban adtuk meg az összes (vagy akár a tetszőlegesen kiválasztott) paraméterfile elérhetőségét. A további analízisekhez Python 2.4, ArcGIS 9.3 szoftvereket használtunk. Egy Python script segítségével (12. melléklet) a .tif kiterjesztésü adatokat EOV-be konvertáltuk (valamint az egyes pixel értékeket 0,0001 szorzótényezővel módosítottuk). A kiválasztott mintaterületekre statisztikai értékeléseket végeztem, szintén Python script alkalmazásával (13. melléklet), melyben egy adott könyvtár összes .tif kiterjesztésű elemeire az ArcMap Zonal statistics eszközét futtattuk le, majd a kapott eredményeket táblázatosan jelenítettük meg (.dbf). Ezen adatok további értékeléséhez Microsoft Excel és SPSS programokat használtunk.

A mezőgazdaságban egy kedvezőbb időjárású év jobb termése, vagy egy száraz év rossz eredménye többnyire az időjárási változékonyság következménye. Ráadásul egy-egy területen évente más növényt termesztenek, így nemigen kínálkozik lehetőség azonos helyen a növények terméshozamát a klimatikus adatokkal megfelelő részletességgel kapcso-

\footnotetext{
${ }^{11}$ Maximum Value Composit (Maximum érték kompozit)
} 
latba hozni. Vizsgálataim szerint azonban az erdők alkalmasak lehetnek egy ilyen elemzésre, hiszen elhelyezkedésük sok éven át állandó, és öntözéssel a természetes csapadék hatását sem módosítják. (A vizsgálathoz szóba jöhettek volna még a természetes gyepek, ezek azonban sekélyebb gyökérzetük miatt sokkal inkább kötődnek a mindenkori csapadékokhoz.) Ezenfelül a müholdas adatok jelentősen javuló térbeli (és egyéb minőségi) felbontása, valamint az azokhoz való hozzáférés könnyebbsége lehetőséget biztosít az erdőállományon keresztül a klímahatás értékelésére.

A biomassza-produkció és a csapadék kapcsolatának jellemzéséhez tehát a vizsgált kistáj erdőfoltjait határoltam le (57. ábra). Az erdőgazdálkodás szerepe - ahogy fentebb is bebizonyosodott - jelentős, de nagy, összefüggő, homogén erdőterületeket ritkán találunk, ezért kis kiterjedésű, homogénnek tekinthető erdőfoltokat különítettem el. Öshonos állományok ma már csak nagyon kis kiterjedésben vannak jelen, többnyire telepített akác, fekete fenyő és erdei fenyő jellemzi a tájat.

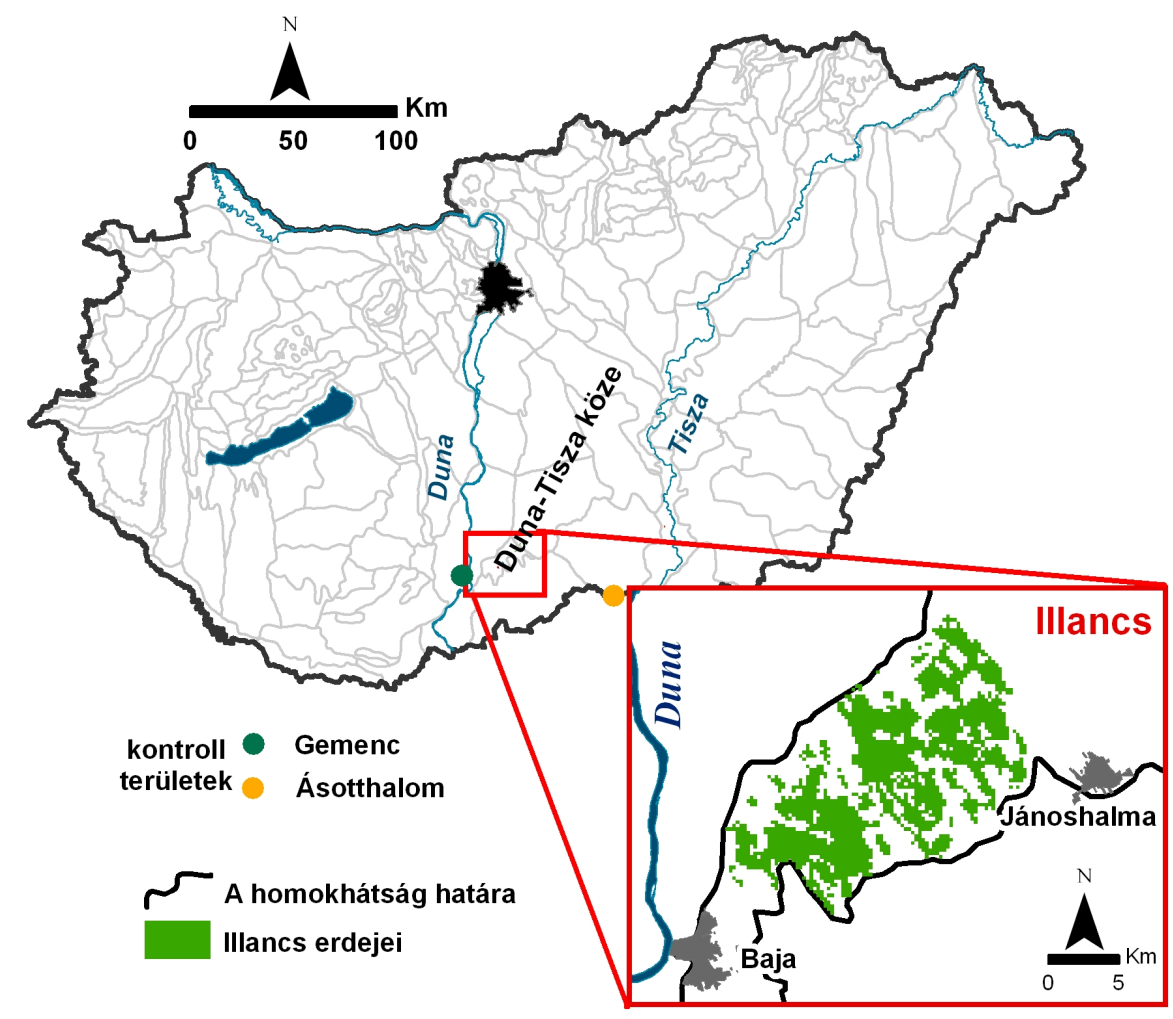

57. ábra. A vizsgált mintaterületek elhelyezkedése a Duna-Tisza közén

A főbb erdőtípusok vegetációs dinamikáját 10 éves adatsor alapján (2000-2009) elemeztem, és kapcsolatot kerestem a csapadék és az éves biomassza-produkció között. A vegetációs dinamikát csak a vegetációs periódusban vettem figyelembe (áprilistól szeptemberig), mert egyrészről ez a periódus a fák szempontjából a legaktívabb időszak, másrészről pedig a téli hó- és felhőborítottság által befolyásolt pixelértékek ez elemzést jelen- 
tősen befolyásolhatják. Kontroll területként olyan erdőket választottam, ahol a talajvízsüllyedés kevésbé jelentős, és ahol a talajvíz könnyen elérhető a fák számára (ásotthalmi erdők, Gemenci erdő)

\subsection{Eredmények}

\subsubsection{Illancsi telepített erdők biomassza-produkciója és a csapadék kapcsolata}

A vegetációs indexekből rajzolt éves görbék tendenciái egyértelmüen mutatják az akác (lombhullató) és fenyő (tülevelü) erdőtípus eltérő természetbeli tulajdonságait (14. melléklet). A lombhullató erdőt alacsonyabb értékek jellemzik a téli periódusban, mint a tülevelü erdőket - köszönhetően a lombozat eltérő tulajdonságainak. A vegetációs időszak során nagyobb felületüvé váló lombozat miatt a lombhullató erdő magasabb értékeket is ér el, mint a tülevelü erdő, így a görbék amplitúdója is nagyobb, melyet a levelek eltérő tulajdonságai támasztanak alá.

A két vegetációs index értékeinek különbségei abból adódnak (58. ábra), hogy amíg az NDVI csak a vörös és infravörös sávok reflektancia-értékei alapján számítódik, addig az EVI-t kifejezetten úgy fejlesztették ki, hogy a vegetációs jel érzékenységét a háttérjel duplázásával és az atmoszférikus hatások csökkentésével optimalizálja (Huete et al. 2002, Matsushita et al. 2007). A továbbiakban a kiértékelésekben habár mind a két index megjelenik, ezek alapján a vizsgálat döntően mégis az EVI értékekre koncentrál.
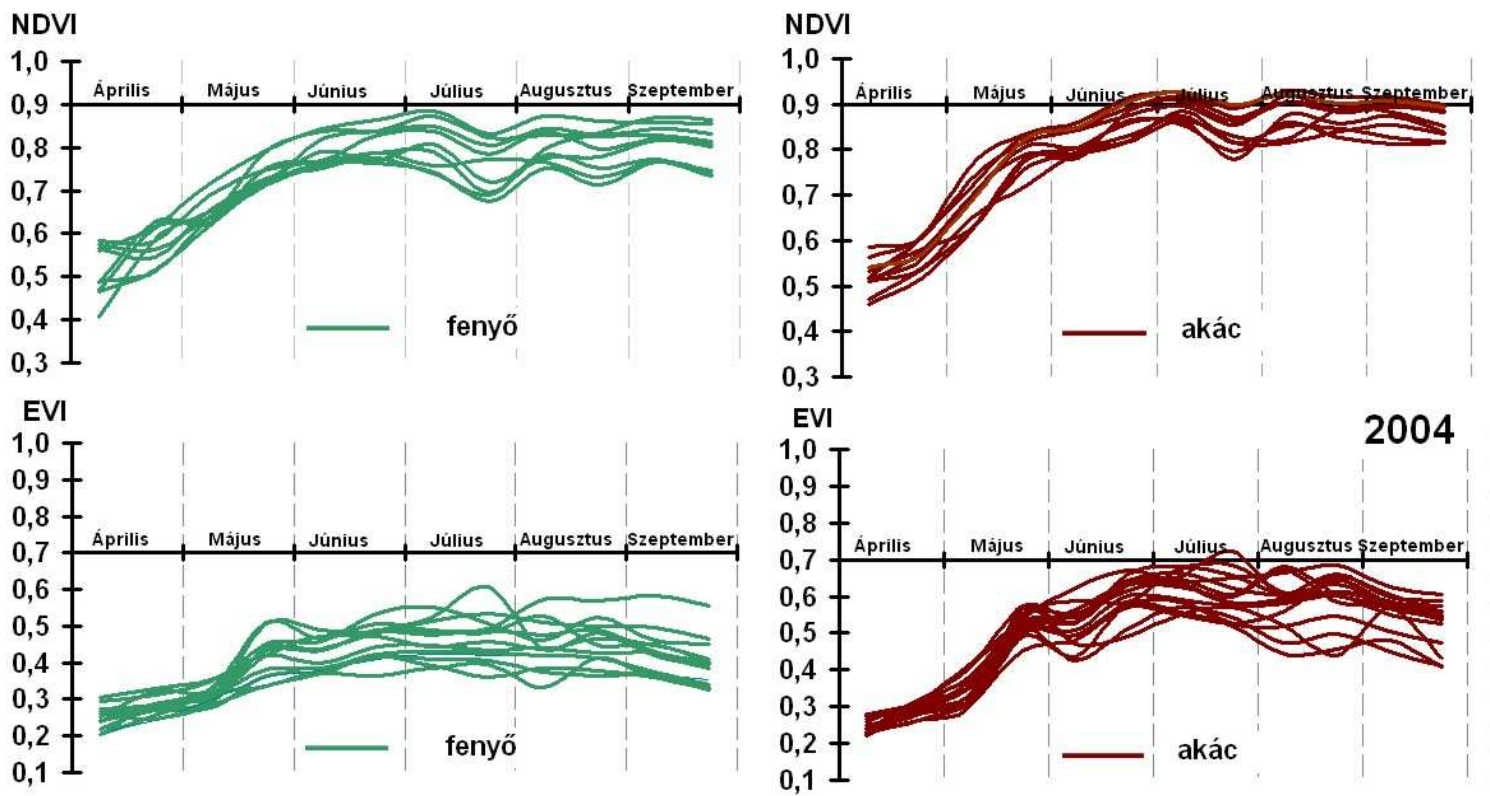

58. ábra. A vizsgált terület lombhullató és tülevelü erdöinek vegetációs index értékei egy szélsöségektöl mentes, egyenletes csapadékeloszlású évben 
Az éves biomassza alakulását meghatározza a csapadék eloszlása az Illancsi erdők esetében. A vegetációs periódus első részében hullott kevés csapadék a teljes lombozat későbbi kifejlődését eredményezi (59. ábra), lásd a görbe meredek szakaszának eltolódását 2001 májusában a 2004-es évhez viszonyítva (2001 változó, 2004 egyenletes csapadékeloszlású évek). Az őszi csapadékok kisebb jelentőségét a 2001-es év példáján szintén megfigyelhetjük. Ha összehasonlítjuk az 5. táblázatban az éves csapadékösszegeket az egyes évekhez tartozó, vegetációs index értékekből számolt ferdeséggel, nem minden jelentős éves csapadékú esztendő biomasszája tolódik el jelentősen negatív irányban, mely bizonyíték a csapadékeloszlás jelentőségére a területen.
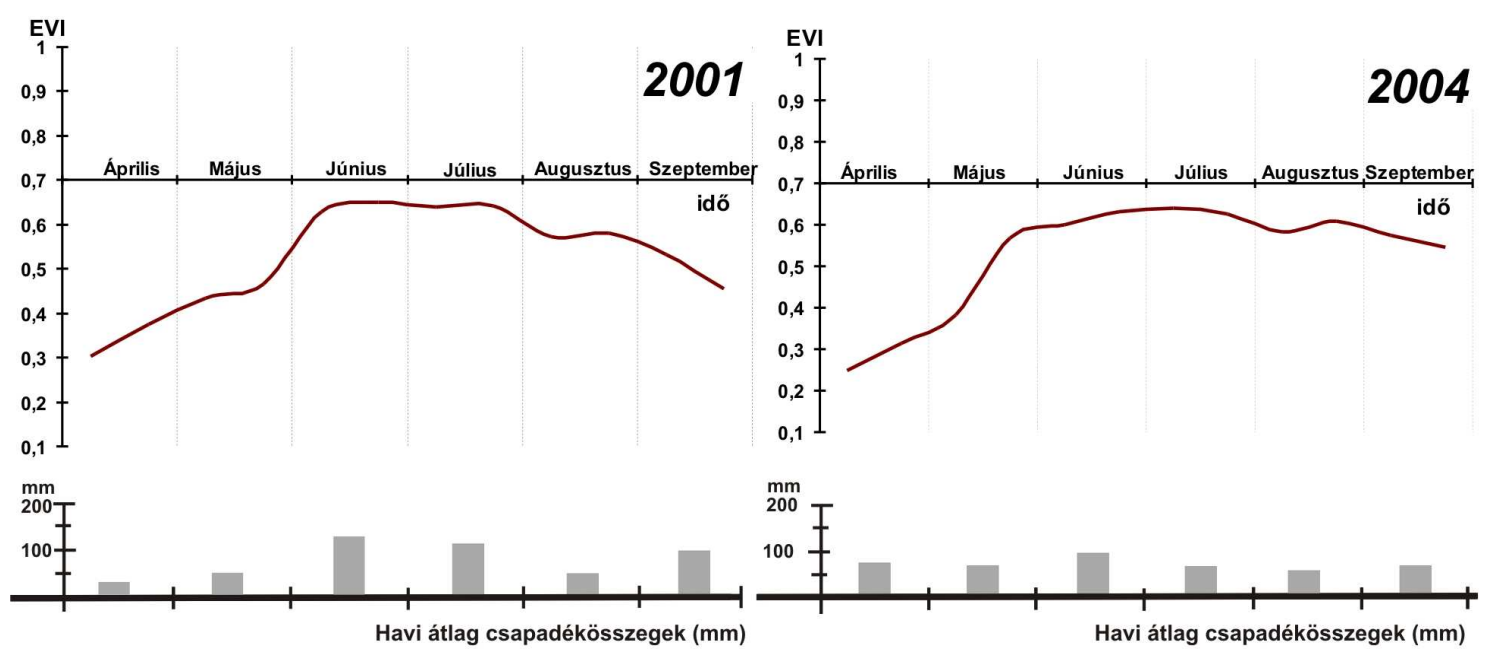

59. ábra. Lombhullató erdők vegetációs index görbéi különbözö csapadékeloszlású években

5. táblázat. Az Illancs erdőfoltjainak EVI index értékei alapján számolt „ferdeség”, 12 , átlagos biomassza, az egyes évek csapadékösszegei, valamint a Pálfai-féle aszályossági index (PAI) az Illancson

\begin{tabular}{|c|c|c|c|c|c|c|c|c|c|c|}
\hline $\mathbf{E} \mathbf{v}$ & $\mathbf{2 0 0 0}$ & $\mathbf{2 0 0 1}$ & $\mathbf{2 0 0 2}$ & $\mathbf{2 0 0 3}$ & $\mathbf{2 0 0 4}$ & $\mathbf{2 0 0 5}$ & $\mathbf{2 0 0 6}$ & $\mathbf{2 0 0 7}$ & $\mathbf{2 0 0 8}$ & $\mathbf{2 0 0 9}$ \\
\hline Átlagos ,ferdeség” & $-1,0$ & $-0,7$ & $-0,8$ & $-1,0$ & $-1,1$ & $-1,3$ & $-1,2$ & $-0,8$ & $-0,9$ & $-0,9$ \\
\hline $\begin{array}{c}\text { Biomassza- } \\
\text { produkció }\end{array}$ & 5,01 & 5,28 & 5,25 & 4,81 & 5,31 & 5,3 & 5,4 & 5,17 & 5,35 & 5,1 \\
\hline Átlag EVI értékek & 0,43 & 0,45 & 0,44 & 0,41 & 0,45 & 0,45 & 0,46 & 0,45 & 0,47 & 0,44 \\
\hline $\begin{array}{c}\text { Éves csa- } \\
\text { padékösszeg (mm) }\end{array}$ & 319 & 685 & 414 & 417 & 753 & 663 & 507 & 565 & 537 & 560 \\
\hline $\begin{array}{c}\text { PAI } \\
\left({ }^{\circ} \mathrm{C} / 100 \mathrm{~mm}\right)\end{array}$ & 8,7 & 3,4 & 8,4 & 15,0 & 5,9 & 3,7 & 5,6 & 12,5 & 6,4 & 8,3 \\
\hline
\end{tabular}

A kutatók általában átlag, minimum és maximum értékeket használnak a különböző paraméterek közötti kapcsolatok és a trendek vizsgálatához. A természetben zajló folyamatok azonban rendkívül összetettek. Például a növények által „termelt biomassza” is sok

\footnotetext{
${ }^{12}$ az eltolódott „,n̈vekedés-megugrás” jellemzésére (negatív irányban eltolt, asszimetrikus eloszlás)
} 
tényező függvénye. Ha megnézzük az Illancs erdeinek átlag EVI értékeit és az éves csapadékösszegeket, tehetünk néhány egyértelmü megállapítást (5. táblázat). Például a 2003-as évet alacsonyabb csapadék és alacsony EVI értékek jellemeznek. De hogyan lehet az, hogy a 2000-es év kevesebb csapadékösszeggel szerepel és mégis nagyobb az EVI értéke? A 2000es év vízháztartása igen szélsőségesen alakult Magyarországon: 1999 az évszázad egyik legcsapadékosabb éve volt, az év végén olyan sok csapadék hullott, hogy óriási vízborítások alakultak ki, viszont 2000 az évszázad legszárazabb éve lett, úgy, hogy az év eleje még átlag közeli volt, majd később szinte nem is hullott csapadék. Azaz az év elejét vízbőség, a későbbi időszakot viszont nagy szárazság jellemezte. A Pálfai-féle aszályossági index értékei szoros kapcsolatban állnak a biomassza-produkcióval $(r=-0,79)$. Szembetünö, hogy a vizsgált 10 évből 7 aszályosnak számít (gyakorlati tapasztalatok szerint PAI>6 felett tekintünk egy évet aszályosnak), és ebből kettő a rendkívül súlyos aszály kategóriába esik.

Láthattuk, hogy a csapadékeloszlás, a hőmérséklet és a termőhelyi adottságok különbségei miatt az egyes erdőfoltok vegetációs indexeiből rajzolt görbék különböznek, ugyanarra az erdőtípusra adott évben, valamint az egymást követő években is. Hogy az erdők vegetációs aktivitását összehasonlíthassuk ezen indexek alapján, kiszámítottuk a görbe alatti területeket (60. ábra), melyek gyakorlatilag a vizsgált időszak alatt keletkezett biomassza összegét mutatják. Ez a dimenzió nélküli szám lehetőséget nyújt a biomassza összehasonlítására különböző években (különböző csapadékeloszlás mellett).

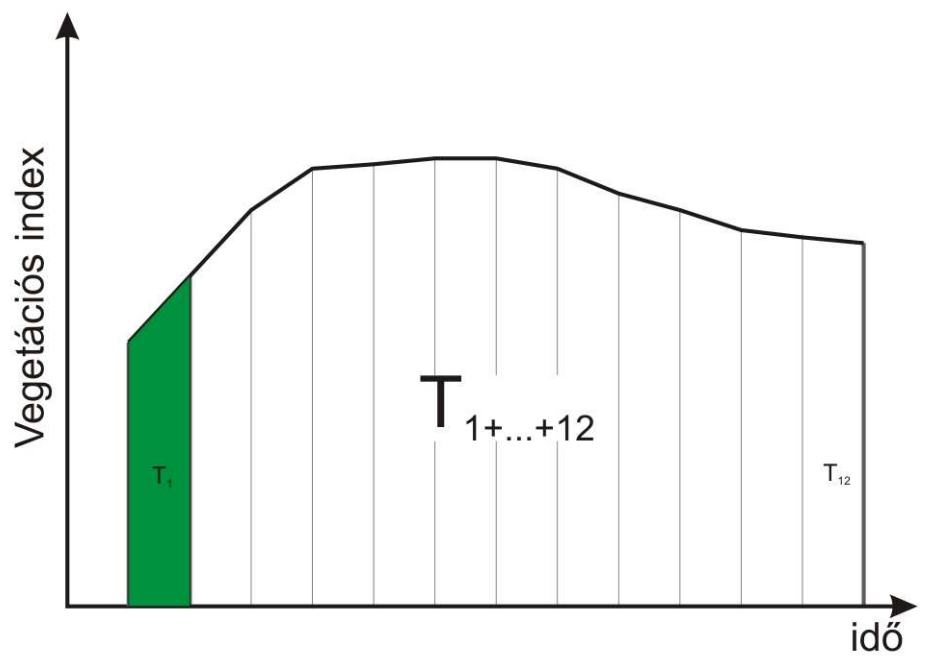

60. ábra. A biomassza számítása (a görbe pontjai reprezentálják a 16-napos kompozit képek vegetációs index értékeit a vegetációs periódusban (áprilistól szeptemberig).

4 tülevelü és 4 lombhullató erdőfoltot választottam ki véletlenszerűen a vizsgált területen az első analízishez (2000-2008), és evvel a módszerrel számoltam a biomasszaprodukció éves értékeit (az erdőfoltok pixelértékeinek átlagai alapján). A csapadék szempontjából a vizsgált évet megelőző év szeptembere és az adott év vegetációs periódusainak hónapjai között egészen az adott év szeptemberig definiáltunk időszakokat minden lehet- 
séges kombinációban (például szeptember-április, szeptember-május, szeptemberjúnius...október-április, október-május, október-június stb.), és megvizsgáltuk a kapcsolatukat a számított biomassza-értékekkel. Az erdőfoltokkal való korreláció eredményét a 6 . táblázat mutatja be. A bemutatott intervallumok a matematikailag legerősebb kapcsolatokat mutatják. Mivel a kistájon nincs részletes klímaészlelés, a számításokat a legközelebbi meteorológiai állomás adatai (Kiskunhalas) alapján végeztük.

6. táblázat. A csapadék és a biomassza-produkció közötti kapcsolat vegetációs indexek alapján 2000-2008 között (A római számok az év hónapjait jelölik).

(**A korreláció a 0.01 szinten szignifikáns; *A korreláció a 0.05 szinten szignifikáns)

\begin{tabular}{|c|c|c|c|c|}
\hline Vizsgált erdőfolt & $\begin{array}{c}\text { Korrelációs } \\
\text { koefficiens (r) } \\
\text { EVI }\end{array}$ & $\begin{array}{c}\text { Meghatározó } \\
\text { időszak } \\
\text { EVI }\end{array}$ & $\begin{array}{c}\text { Korrelációs } \\
\text { koefficiens (r) } \\
\text { NDVI }\end{array}$ & $\begin{array}{c}\text { Meghatározó } \\
\text { időszak } \\
\text { NDVI }\end{array}$ \\
\hline Fenyő 1 & $0.84^{* *}$ & III-VI & $0.86^{* *}$ & III-VI \\
\hline Fenyő2 & $0.77^{*}$ & II-VI & $0.91^{* *}$ & II-VI \\
\hline Fenyő 3 & $0.73^{*}$ & III-VI & $0.93^{* *}$ & III-VI \\
\hline Fenyő 4 & $0.71^{*}$ & III-V & $0.85^{* *}$ & III-V \\
\hline Akác 1 & $0.95^{* *}$ & III-VI & $0.92^{* *}$ & III-VI \\
\hline Akác 2 & $0.87^{* *}$ & IV-VI & $0.89^{* *}$ & IV-VI \\
\hline Akác 3 & $0.88^{* *}$ & III-VI & $0.84 * *$ & III-VI \\
\hline Akác 4 & $0.84^{* *}$ & III-VI & $0.83^{* *}$ & III-VI \\
\hline
\end{tabular}

Az eredmények azt mutatják, hogy valóban erős kapcsolat van a csapadék és a biomassza között, mind a két vegetációs index alapján. Az EVI alapú biomassza-értékek erősebb kapcsolatot mutatnak az akác esetében $(0,88)$, mint a fenyőnél $(0,76)$. Az erdők biomasszája tekintetében a márciustól május-júniusig tartó időszak csapadéka bizonyult a legmeghatározóbb periódusnak. Mivel a talajvíz mélyen van, a téli csapadék szerepe kevésbé fontosabb. A nagyobb mennyiségü szeptemberi csapadéknak (a vegetációs periódus végén) már nincs jelentősebb szerepe (ahogy ez a nyers adatokból is látszott). A fentiek azt mutatják, hogy a vegetációs aktivitás a vegetációs periódus első felében hullott csapadéktól függ a tájon.

Az elemzést kiterjesztettuik Illancs többi erdejére is (61. ábra), különösen ügyelve a vegyes pixelek kiküszöbölésére. Az eddigi eredmények hasonlósága miatt továbbá nem különítettük el egymástól a különböző erdőtípusokat és a jobb háttérkorrekció miatt az EVI index-szel kapott korrelációkat elemeztem részletesebben. A változó kitettségi és talajtani adottságban való különbségek miatt a korrelációk nagyobb változatosságot mutattak, de a fentebb bemutatott tendencia így is jól látható. 


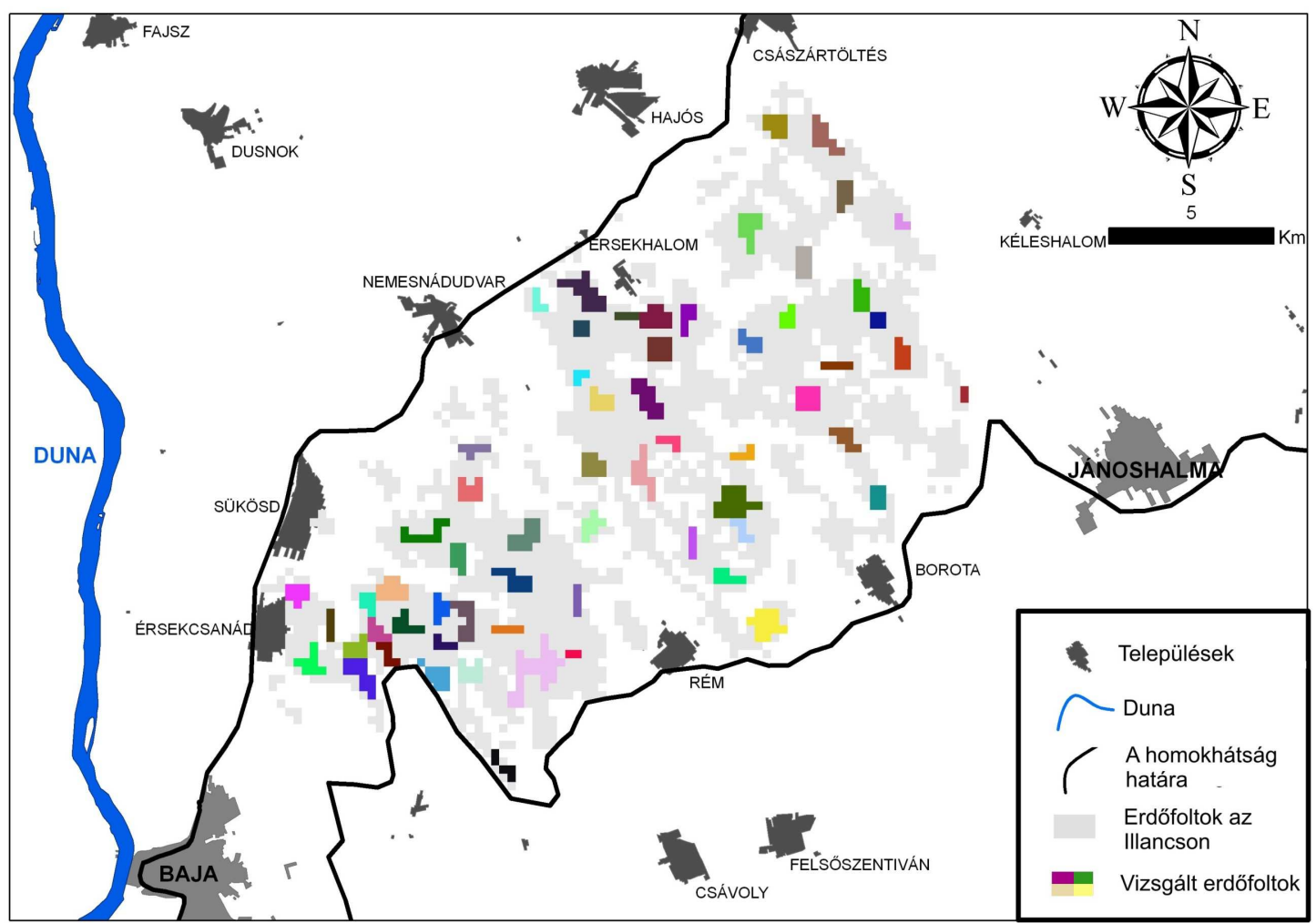

61. ábra. Kiterjesztett analízis homogén erdöfoltokra, az Illancs területén

Ha átlagolunk minden korrelációs koefficienst minden vizsgált periódusra, az egyes periódusok szerepe még egyértelmübbé válik (62. ábra). Három intervallum mutatja a legerősebb kapcsolatot. A vizsgált erdőfoltok 65\%-ban az április-június, 35\%-ban a márciusjúnius, és 5\%-ban a február-június mutatja a legerősebb korrelációkat (63. ábra) ${ }^{13}$. A téli csapadék kevésbé bizonyul meghatározónak, és a további hónapok, mint a július, augusztus, szeptember szintén nem eredményeznek jobb korrelációkat.

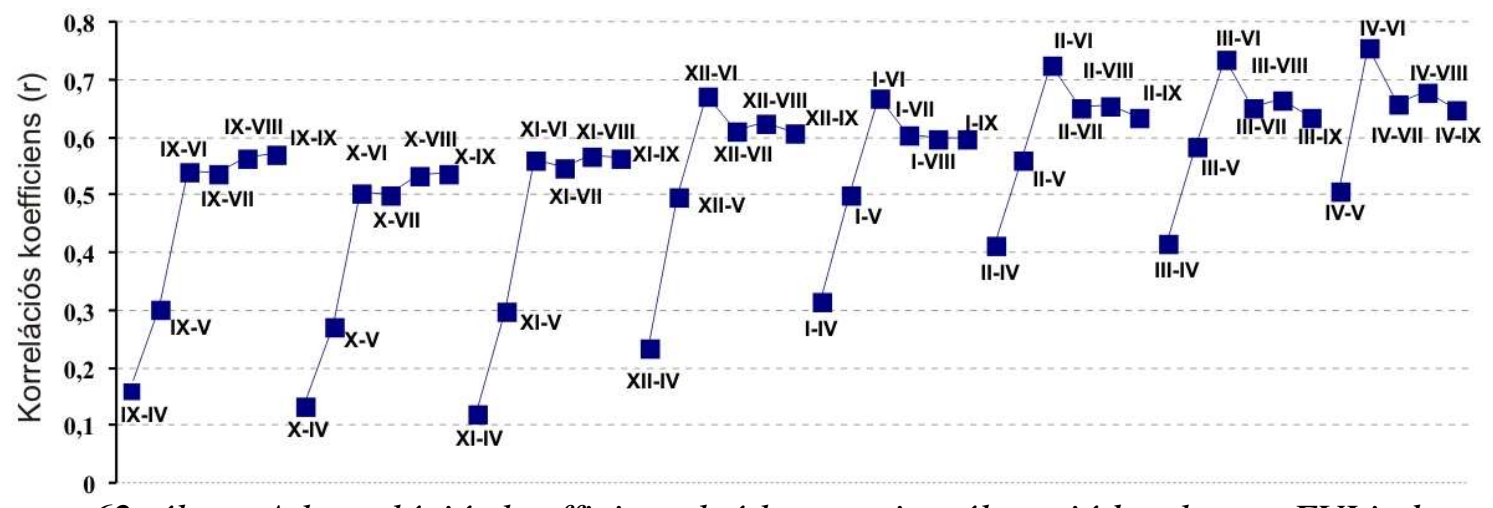

62. ábra. A korrelációs koefficiensek átlaga a vizsgált periódusokra az EVI index alapján

(A római számok az év hónapjait jelölik)

\footnotetext{
${ }^{13}$ Ezen a tájon valóban igaz az a népi bölcselet, mely szerint a májusi eső aranyat ér.
} 


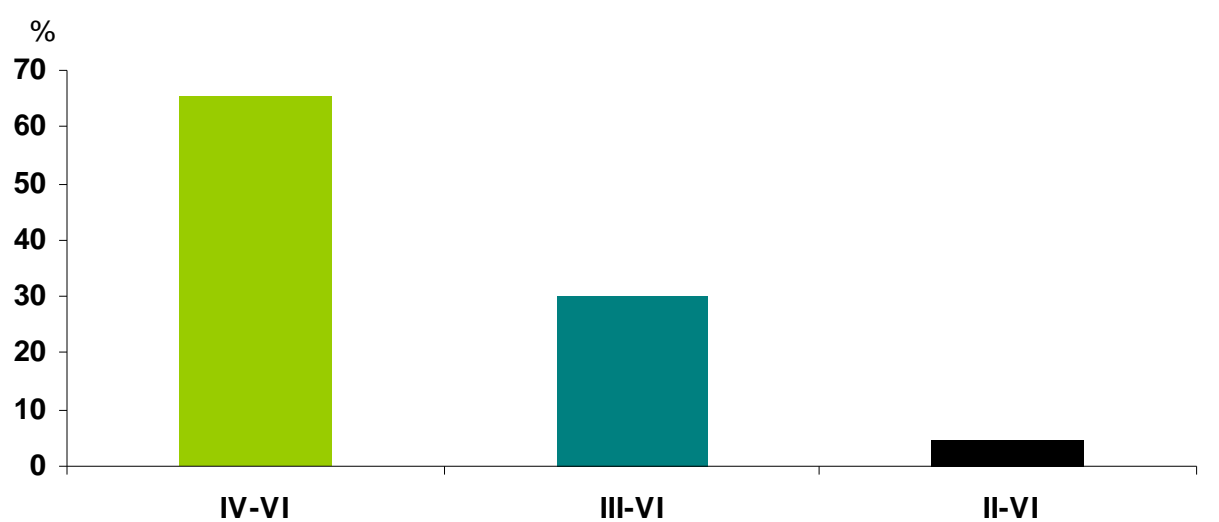

63. ábra. A legerösebb kapcsolatot mutató intervallumok százalékos megoszlása (A római számok hónapokat jelölnek)

Az analízis eredményei alátámaszthatóak a régió talajadottságaival is. Jellemzően homoktalajok fordulnak elő rajta, melyek víztároló kapacitása kicsi, és a talajvízszint is olyan mélyen van, hogy annak tavaszi utánpótlódása sem tud jelentősen hozzájárulni a terület növényzetének jobb vízellátásához. A homoktalajok szélsőséges nedvesség dinamikájának és fokozott aszály érzékenységének alapvető oka az ásványi és szerves kolloidok hiánya, mely miatt nem alakulhat ki a felszínre jutó víz befogadására, hasznos tárolódására, a talajvízből történő kapilláris vízutánpótlásra alkalmas pórusteret biztosító stabil talajszerkezet, másrészről kis diszponzibilis vízkészletük pedig csak rövid időre képes biztosítani a növények vízellátását (Várallyay 1984, 1988, Cserni - Füleky 2008).

Ezen talajtulajdonságok voltak mindemellett az okai annak is, hogy az erdészet kis vízigényű fajokat telepített a területre. Irodalmi adatok alapján a jellemző fafajok vízigényei: akác (Robinia pseudo-acacia) 279 mm; fekete fenyő (Pinus nigra) $185 \mathrm{~mm}$; erdei fenyő (Pinus sylvestris) 205 mm (Szofridt 1994).

\subsubsection{Kontroll erdőterületek biomassza-produkciója és a csapadék kapcsolata}

Hogy a vegetációs indexek alkalmazhatóságát megvizsgálhassuk a tájak klímaérzékenysége kapcsán, választottunk olyan kontroll területeket is a mintaterület közelében, melyeken a vegetáció aktivitása nemcsak a csapadék eloszlásának változatosságán múlik, hanem más egyéb (talaj)vízforrásokat is tud használni. Ilyen terület például a gemenci erdő a Duna árterületén, mely a Duna-Dráva Nemzeti Park része (57. ábra). A rendszeres áradások és a folyamatos kapcsolat a folyómederrel a kavicsos, homokos üledéken keresztül jó körülményeket biztosítanak a fáknak. Az erdőt nem akác és fenyő, hanem egyéb, nagyobb vízigényü fafajok alkotják.

Itt a görbe alatti területek számításából kapott biomassza nem mutatott erős korrelációt semelyik hónapok csapadékösszegeivel sem. A korrelációs együtthatók az NDVI 
esetében $-0,2<\mathrm{r}<+0,2$ között, az EVI esetében $-0,5<\mathrm{r}<+0,2$ között mozogtak (64. ábra). Már önmagában a vegetációs index görbék lefutásában sem mutatkozott akkora különbség a különböző csapadékú évek között Gemenc esetében (15. melléklet), mint az illancsi erdőknél, mely szintén a homoki erdők érzékenységét támasztja alá. Ezért, az előző hipotézishez kapcsolódva, e mintaterület (Gemenc) nem számít érzékeny területnek a klímaváltozás szempontjából.

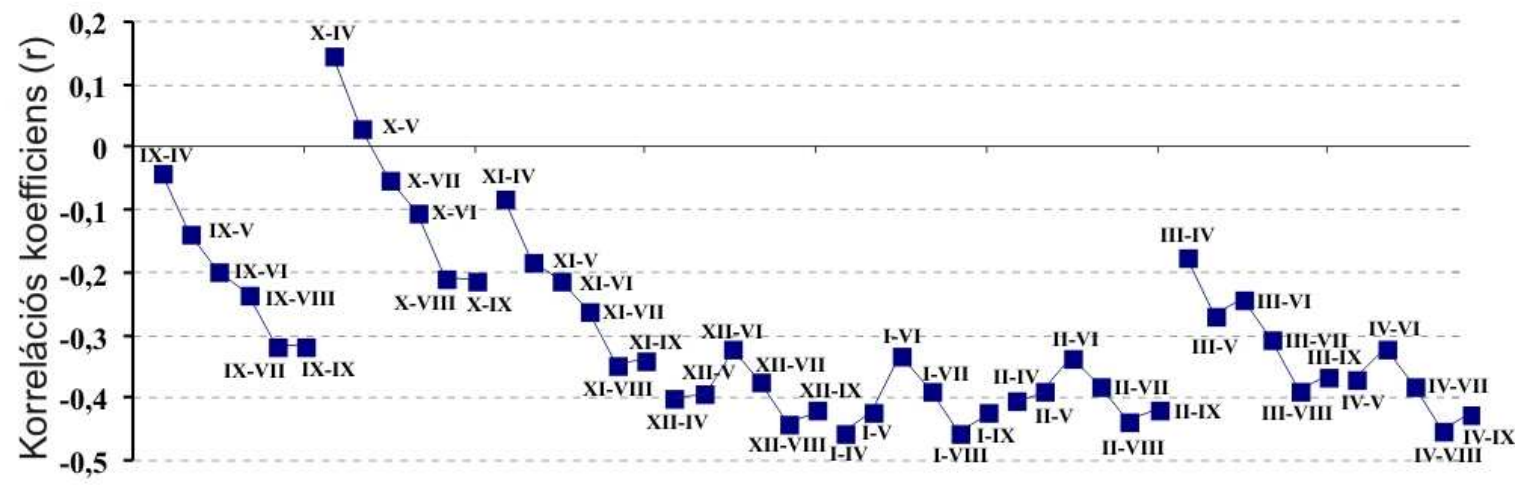

64. ábra. Korrelációs koefficiens értékek a Gemenci erdöre az EVI index alapján (A római számok hónapokat jelölnek)

További mintaterületként választottunk egy jelentősebb kiterjedésű fenyőerdőt a Duna-Tisza köze délkeleti peremén (Ásotthalom) kötöttebb talajon, ahol a talajvízszintsüllyedés kevésbé meghatározó (1-2 m) és a folyók hatása sem befolyásolja jelentősen a talajvíz szintjét. (Olyan területet, ahol kis vízigényü fafajt ültetnek jó minőségü talajra, nem sokszor lehet találni, hiszen ezeket inkább szántóföldi müvelésre használják). Az elemzés ebben az esetben szintén erős kapcsolatot mutatott a csapadékkal (7. táblázat), habár a tavaszi hónapok dominanciája kevésbé volt jelentős. De a kapcsolat ez esetben már a téli hónapokkal együtt a meghatározóbb (december-június), ami a talajvíz nagyobb szerepére utalhat és kiemelendő a júniusi csapadékösszeg befolyásoló hatása is a kapcsolat szempontjából (65. ábra). A klíma tekintetében tehát ez a terület nem sorolható már az érzékeny kategóriába, hiszen széles intervallumban meghatározó a csapadék szerepe, melyet a talaj képes tárolni, és később a növényzet ezt hasznosítani is tudja.

\section{7. táblázat. A csapadék és a biomassza kapcsolata Ásotthalmi fenyöerdök alapján}

\begin{tabular}{|c|c|c|c|c|c|}
\hline $\begin{array}{c}\text { Vizsgált } \\
\text { erdőfolt }\end{array}$ & Település & $\begin{array}{c}\text { Korrelációs } \\
\text { koefficiens (r) } \\
\text { EVI }\end{array}$ & $\begin{array}{c}\text { Meghatározó } \\
\text { időszak } \\
\text { EVI }\end{array}$ & $\begin{array}{c}\text { Korrelációs } \\
\text { koefficiens } \\
(\mathbf{r}) \\
\text { NDVI }\end{array}$ & $\begin{array}{c}\text { Meghatározó } \\
\text { időszak } \\
\text { NDVI }\end{array}$ \\
\hline Fenyő & Ásotthalom & 0,80 & XII-VI & 0.76 & I-VIII \\
\hline
\end{tabular}




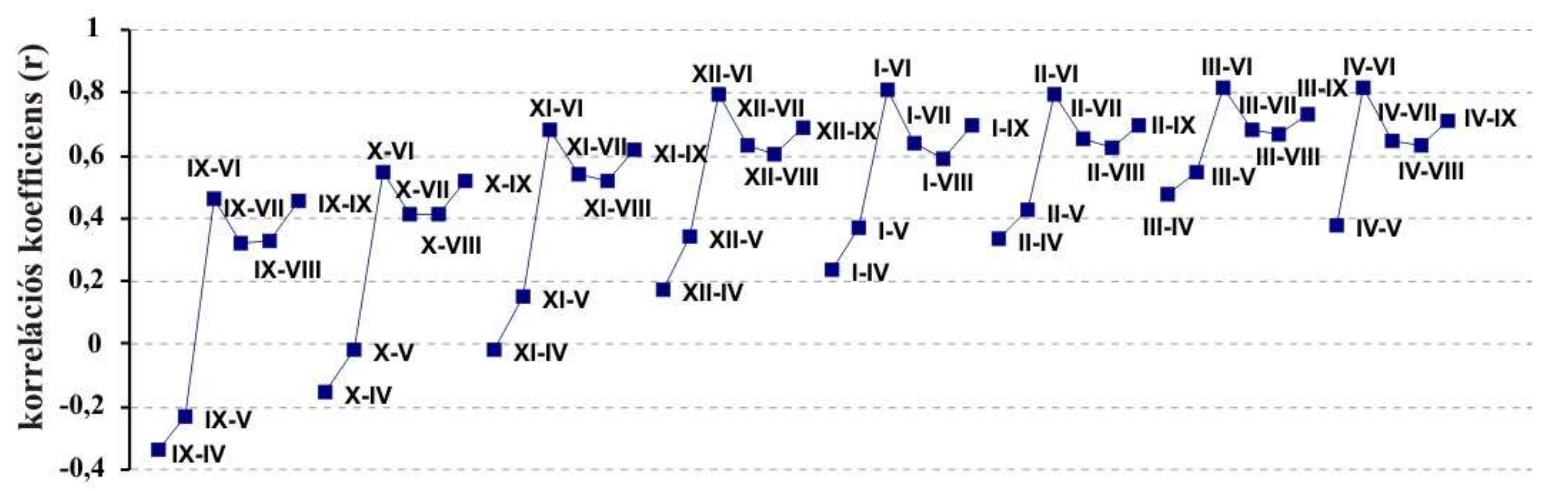

65. ábra. Korrelációs koefficiens értékek az ásotthalmi erdö esetén az EVI index alapján (a római számok hónapokat jelölnek)

\subsection{Megállapítások a tájérzékenység térinformatikai értékeléséhez}

16 napos MODIS kompozit képeket vizsgálva bebizonyosodott, hogy a $250 \mathrm{~m}$-es felbontás már nem csak regionális, hanem helyi szintű vegetációs dinamika vizsgálatára is alkalmas lehet, habár a még jobb felbontás jelentősen javítaná az értékelés pontosságát. A vegetáció és a csapadék erős kapcsolata magyarországi erdőtípusok alapján is alátámasztható. A vizsgált tájon a víz fontosságára az eredményül kapott, szűk intervallumban (március-június) meghatározó csapadék utal. A fák itt nem táplálkoznak talajvíz-forrásból, a lehulló csapadékot pedig a homoktalaj csak kis mértékben képes tárolni.

A klíma szcenáriók a Kárpát medencére melegebb nyarakat prognosztizálnak, a csapadék további csökkenésével így a szárazodás fokozódhat. A „klíma-érzékeny” területeken - mint a vizsgált kistáj - az élővilág és az ember is adaptálódni kényszerül. A változó tájban ennek már számos példáját láthatjuk: kevesebb vizes élőhely, csökkenő vizes élőhelyekhez kötődő madárállomány, a nagyobb vízigényű fák csúcsszáradása, bizonyos régiók vízhiány miatti elnéptelenedése, invazív fajok elöretörése.

E vizsgálat bebizonyította, hogy vegetációs indexekkel lehetőség nyílhat a klíma szempontjából veszélyeztetett érzékeny területek lehatárolására. Az elmúlt 30-40 évben a víz limitáló faktorrá vált a kistájban. Ez a szűk keresztmetszet adott lehetőséget arra, hogy a csapadék szempontjából e kistáj biomassza-produkcióját értékeljük. 


\section{GAZDÁLKODÓK ÉS A SZÁRAZODÁS}

\subsection{Illancs és az ember, valamint a szárazodás hatása az illancsi gazdálkodásra}

A 18. század végi források szerint az Illancson, a dunai magaspartot övező területeken már voltak települések - az I. katonai felmérés feliratai szerint „Sükösd, Nádudwár, Tsászár Döltés”. A települések (ma Érsekhalom, Sükösd, Nemesnádudvar, Császártöltés) mindegyike létezett már a 17. század előtt is, de a történelem során az ellenség elől a népesség a Duna-völgyi mocsarakba húzódott vissza, s a török hódoltság alatt jelentős részük is elnéptelenedett. A törökök kiüzése után magyar és német (néhol szerb) telepesek népesítették be a vidéket. Császártöltést például az 1700-as évek közepén telepítette be a kalocsai érsek német családokkal, akiktől a szőlőkultúra fellendítését várta (Arnold - Knipl 2003).

A kistáj DK-i peremén ülö települések, Borota és Rém története is jóval a török hódoltságot megelőző időkre nyúlik vissza, habár a 18. században igen kisszámú lakosság jellemezte. A két település az I. katonai térkép szelvényein (1780-as évek) „Borota Puszta” és „Rém puszta” néven szerepel. A 19. század végére kezdték a tanyák a délkeleti peremet igazán meghódítatni, virágzásnak indult a kisparaszti gazdálkodás. A tanya, mint különleges szórványtelepülésforma, egyszerre felelt meg a táj által biztosított ökológiai, gazdálkodási és társadalmi igényeknek. Általában az eltérő hasznosítási lehetőségű tájrészek határzónáiban húzódtak a tanyák a Homokhátságon (Iványosi Szabó 1994), ami az Illancson egyrészről a kistáj határát jelentette (a homokbuckákon legeltettek, a lösz borította területeket pedig szántóművelésre használták), másrészről pedig a buckák közötti mélyedések zártabb rétjein a vízborítás megszűnte után (nyár eleje) szintén tudtak legeltetni. A hegyvidéki filoxérajárványt követően a szőlőművelés egye inkább felkúszott a homokterületekre - a kistáj központi része felé -, mely együtt járt a tanyák hasonló irányú terjedésével is.

Az 1900-as évek elejére a szőlö és gyümölcstermelés a régióban egyre jelentősebbé vált. A gazdasági élet szélesebb síkra való helyezése a vasútvonal építésének évétől, 1903tól számítható. A kisparaszti gazdálkodás virágkorát bizonyítja a Jánoshalmán az 1900-as évek elején már exportra is termelő gyümölcspiac. Az I. világháború előtti adatok szerint Jánoshalma 1913. évi gyümölcsexportja 123 q alma, 854 q szilva, 1104 q szőlő, 497 q kajszi- és őszibarack volt (Kiss-Pető 2005). Óriási árualap termelődött, mely a két világháború között érte el a csúcsát, és a jánoshalmi gyümölcspiac Magyarország 2-3. legnagyobb gyümölcsexport-piacává vált, megélhetést biztosítva a környék lakosságának.

A korábban már spontán kialakult és önállósult települések után, az 1950-es évek első felétől vett nagy lendületet a zárt beépítésű belterületek (önálló települések) immár 
tudatos kialakítása. Emellett a második világháborút követően az Illancs déli részén még nagy számú tanyákban éltek és dolgoztak emberek. A II. világháborút és az átmeneti időszakot követően 1958-1961 között a kollektivizálás jellemezte a mezőgazdaságot. A gazdaságpolitika változása, a nagyüzemi gazdálkodás megjelenése átalakította és ellehetetlenítette a tanyasi életformát, így a tanyák 1986-ig, az általános külterületi építési tilalom feloldásáig szinte teljesen megszüntek létezni (Kiss 2004, Csatári 2006). A fiatalok már a térség falvaiban és városaiban telepedtek le. A térségben a tanyák elnéptelenedéséhez a közmüvek kiépítésének a hiánya, a talajvízszint-süllyedés hatására nehezebbé váló termelés is hozzájátszott.

A politikai és gazdasági rendszerváltás után, az építési korlátozások föloldásával és a föld magántulajdonának visszaállításával megadatott a lehetőség arra, hogy a tanyarendszer visszatérjen természetes fejlődési pályájára (Duró 2005). 1990-ben azonban nem lehetett ott folytatni, ahol négy évtizeddel azelőtt abbamaradt, mert a tanyás határrészek községgé alakításával végérvényesen megváltoztak a tanyai életmód térbeli keretei. A tanyaközségek ma egészen más minőségű településkörnyezetet jelentenek a helybeliek számára. A motorizációval lecsökkentek a távolságok, és a kövesút meg a belterület közelsége fontos tényezővé lépett elő. A külterület fölértékelődésének a jele, hogy az eddig meglehetősen zárt közösségnek számító tanyavilágot más településtípusok lakói is kezdik fölfedezni, új árnyalatokkal gazdagítva a sokszínü tanyai társadalmat (megélhetési kényszer miatt kitelepülők, külföldiek, „,spekulánsok”). „A tanyát, amely a mezőgazdaság településformájaként jött létre, ma is az teszi vonzóvá, ami évszázadokkal ezelőtt: a föld és a természet közelsége meg a szabadság; itt mindig el lehetett bújni és ki lehetett emelkedni” (Duró 2005).

A 20. század végi szárazodás, a talajvízszint csökkenése súlyosan érintette a gazdálkodókat, akiknek egyre jelentősebb gazdálkodási nehézségekkel kellett szembenézniük. Az 1990es években már (a jelentős mértékű talajvízszint-süllyedés miatt) csőkutak ezreit mélyítették szerte a Homokhátságon, és szivattyúkkal termelték ki talajvizet. Csatári 1995-ös kérdőíves kutatása és becslései alapján kiderült, hogy a Homokhátság kútjaiból évente Szeged város vízfogyasztásának megfelelő mennyiségü víz kerül ki (Csatári 2004). Mivel az illegális kutakból származó víznek ára sem volt, korlátlan mennyiségben engedték ki a homoktalajra, mely a meleg nyári napokon nagyon rövid idő alatt el is párolgott.

A Homokhátság vízhiánya mára szociális és gazdasági kérdéssé is vált. Az Illancs egyike azon területeknek, ahol a talajvízszint süllyedése a legnagyobb (2009-re már akár 7 méterrel is mélyebb, mint az 1970-es években volt), és a legmagasabb területeken a talajvíztükör néhol a felszínhez képest 20 méter mélyen található. Kérdésként merülhet fel, 
hogy ezen a területen mennyire érzékelik a gazdák a klímaváltozás hatását? Ha érzékelik, hogyan próbálnak alkalmazkodni? De egyáltalán tudnak-e alkalmazkodni, és milyen gazdasági kára van ezeknek a folyamatoknak?

\subsection{Felhasznált módszerek}

A fenti kérdések megválaszolására a terepbejárások során a lakossággal, erdészekkel, gazdálkodókkal készítettem személyes interjúkat. Kezdetben célom volt az, hogy nagyobb keretek között több településen valósuljon meg kérdőíves felmérés, azonban a gazdálkodásra vonatkozó kérdéseikre nem minden esetben kaptam kielégítő válaszokat. Az emberek jelentős része - munkahely hiányában, a gazdálkodási lehetőségek nehézségei miatt - a közeli városokban, a településeken közhivatalokban vagy szolgáltató jellegü üzletekben dolgozik, vagy állattartásból él (pl. juhtartás és legeltetés) mint vállalkozó, vagy alkalmazott.

2009. február 26.-án, Jánoshalmán szerveződött egy agrárfórum a városi könyvtárban, amely rendezvényre azon környékbeli lakosok jöttek el, akik gazdálkodnak és a jövőben is gazdálkodni szeretnének a térségben. A fórumon szó volt az unió jövőjéről (EP választások), a gazdák 2009-es képzési rendszeréről és a 2009-es támogatási rendszerekről, valamint a résztvevők előadást hallhattak a klímaváltozás magyarországi hatásairól, külön kiemelve a magyar mezőgazdaság és a szárazodás lehetséges összefüggéseit. Ez a fórum jó alkalomnak tünt, hogy kifejezetten azok szólaltassanak meg, akik a térségben gazdálkodtak és gazdálkodnak. E célból kérdőívet készítettem, melyet a résztvevők között szétosztottam (16. melléklet). A kérdőív kérdései azon gondolatmenet mentén füződnek fel, hogy (1) tapasztalják-e a gazdálkodók a klímaváltozás hatásait? (2) mit gondolnak a talajvízszint-süllyedés mértékéről (meg tudják-e becsülni a jelenlegi vízszinteket)? (3) tudnak-e gazdálkodni ilyen feltételek mellett? (4) tapasztalják-e, hogy mások nem tudnak, és akár ez okból költöznek el a vidékről? (5) próbálnak-e alkalmazkodni (művelési-ág váltás), ha az addigi müvelés ma már tovább nem folytatható? (6) és miben látják a térség kiútját a problémából?

\subsection{Eredmények}

Terepbejárásaim során az egyéni interjúkban a megkérdezettek általában a belvízelvezető csatornákat, az 1980-as évek olajkutató fúrásait és a nagy szárazságokat okolják a terület vízháztartásbeli problémájának kialakulásáért. Az elhagyott tanyák kiszáradt ásott kútjai, a réteken 5-6 méter mély, korábban az állatok itatására használt, ma teljesen száraz csorda kutak árulkodnak arról, hogy a víz valóban hiányzik a területről. Vannak, akik - alaptalanul - álmodoznak arról, hogy a régi vizes élőhelyeket visszaállítsák. Láttunk arra törekvéseket, hogy a 
gazda halastavat szeretett volna mesterségesen létrehozni, és a „a nagyapám itt még csónakázott" mondatot szem előtt tartva a talajt bevizsgáltatta, fóliát vásárolt, hogy álmait megvalósítsa. Azonban belegondolva a vízhiány mértékébe és a klímaadottságokba, ez még igazából mesterségesen sem lehet fenntartható. Még alig telt el egy generáció a probléma kiteljesedése óta, és még a vizes élőhelyek környékében lakók közül sokan emlékszenek arra az időre, amikor ezekben a vizes élőhelyekben „bíbicek és más vízi madarak” éltek, halat fogtak, vagy „nézze, ott a nyárfák között harminc éve csak csónakkal tudtunk közlekedni”. Bizonyos években nyár közepéig nem lehetett learatni a szénát a délkeleti perem mélyedéseiben.

A gazdák tapasztalatai Rém és Borota környékén, hogy a hetvenes évek óta tủntek el a vizes élőhelyek, és a gazdálkodásban is érezhető azóta ennek a hatása (pl. az aszályos években „térdig sem nő meg a kukorica”). Az 1990-es évek második felében, a csapadékos évek hatására a mélyebb ásott kutakban feljött a víz, azonban ez időszaktól eltekintve mélyebb kutakból kell szivattyúzniuk a vizet (ami azonban már rétegvíz). A vízügy rendszeresen takarítja a csatornákat a helyiek elmondása szerint, viszont azokban már évtizedek óta nincsen víz. Próbálkoznak vízvisszatartással is több helyen, azonban a mélyebben fekvő területeken ez nem várt ellenállásba ütközött a nedvesebb években. Mélykútijánoshalmi gazdák mesélték, hogy az 1990-es évek végén, amikor Mélykút és Jánoshalma között a csatornákon elzárták a zsilipeket, a jelentős esőzések hatására jelentős vízállások keletkeztek a szántóföldeken, és az évben a földjüket még beszántani se tudták.

Szőlősgazdák a nem is olyan régen még virágzó borkultúráról mesélnek a vidéken. Arról, hogy például milyen egyszerủen megoldható volt az öntözés és a permetezés. Csak markolóval kellett kiásni egy pár méteres mélyedést, felszivattyúzták permetetlé-keverö tornyokba a vizet és a rendszer így működőképes volt sokáig. Borota belterületétől északkeletnek haladva a müút mellett az egykori virágzó szőlőgazdaság nyomairól árulkodnak a nagyüzemi műveléshez használt beton permetlékeverő tartályok, az eredeti helyükről kiforgatva, az út mellett (66. ábra). Ma a borászat ismét fellendülő tendenciát mutat, a nagytermelők bizakodnak, de a kis szőlőtulajdonosok kevésbé, akiknek már nem éri meg a kis parcellák (esetleg sorok) művelése.

A kistáj középső része felé egyre szaporodnak az elhagyatott tanyák. Az udvaron az ásott kutak, a tanyához tartozó kis gyümölcsösök maradványai még ma is tükrözik az egykor virágzó kertgazdaság nyomait (67. ábra). Ezen tanyák udvarát gyakran bérlik méhészek, akik az akác és a terjedő selyemkóró jó mézelő tulajdonságait használják ki, és a helyiek elmondása szerint nagy szerepet játszanak ez utóbbi invazív faj terjedésében is. 


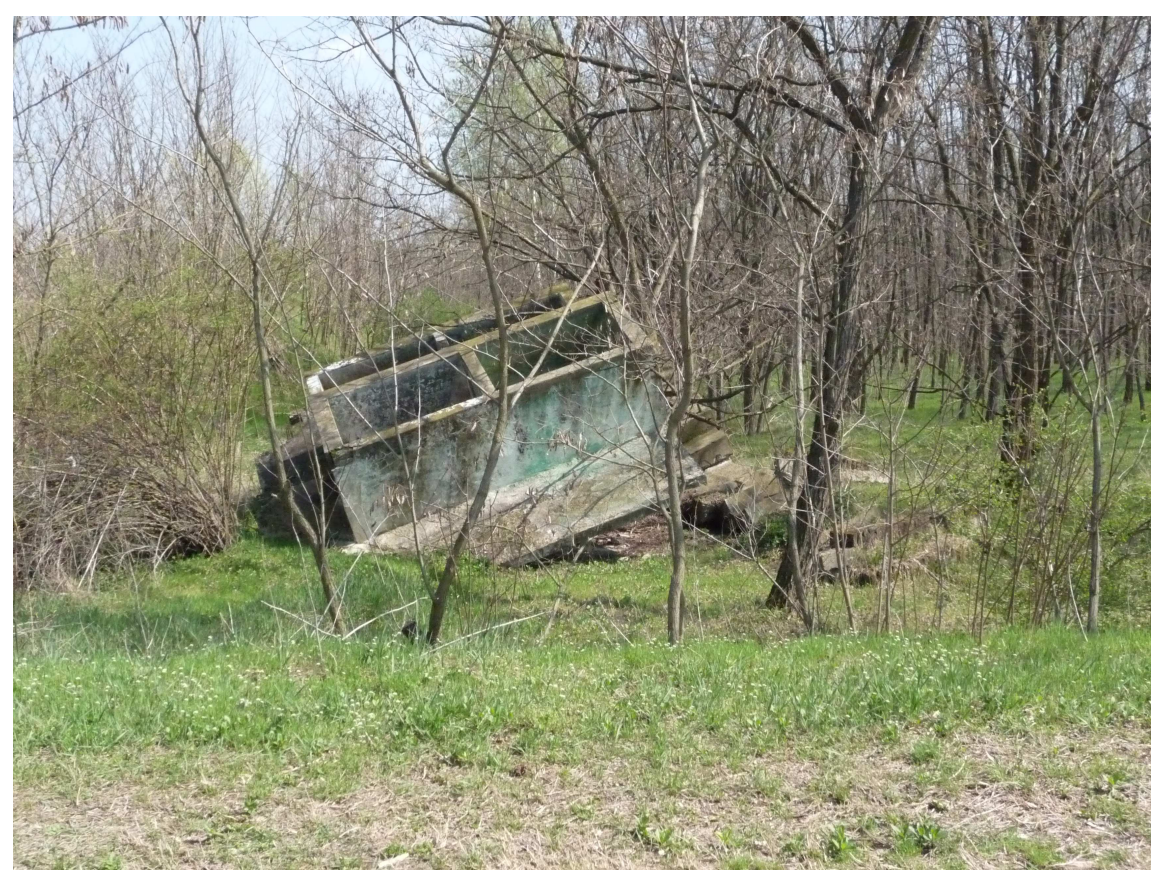

66. ábra. Permetlé-keverö tartályok Borota határában

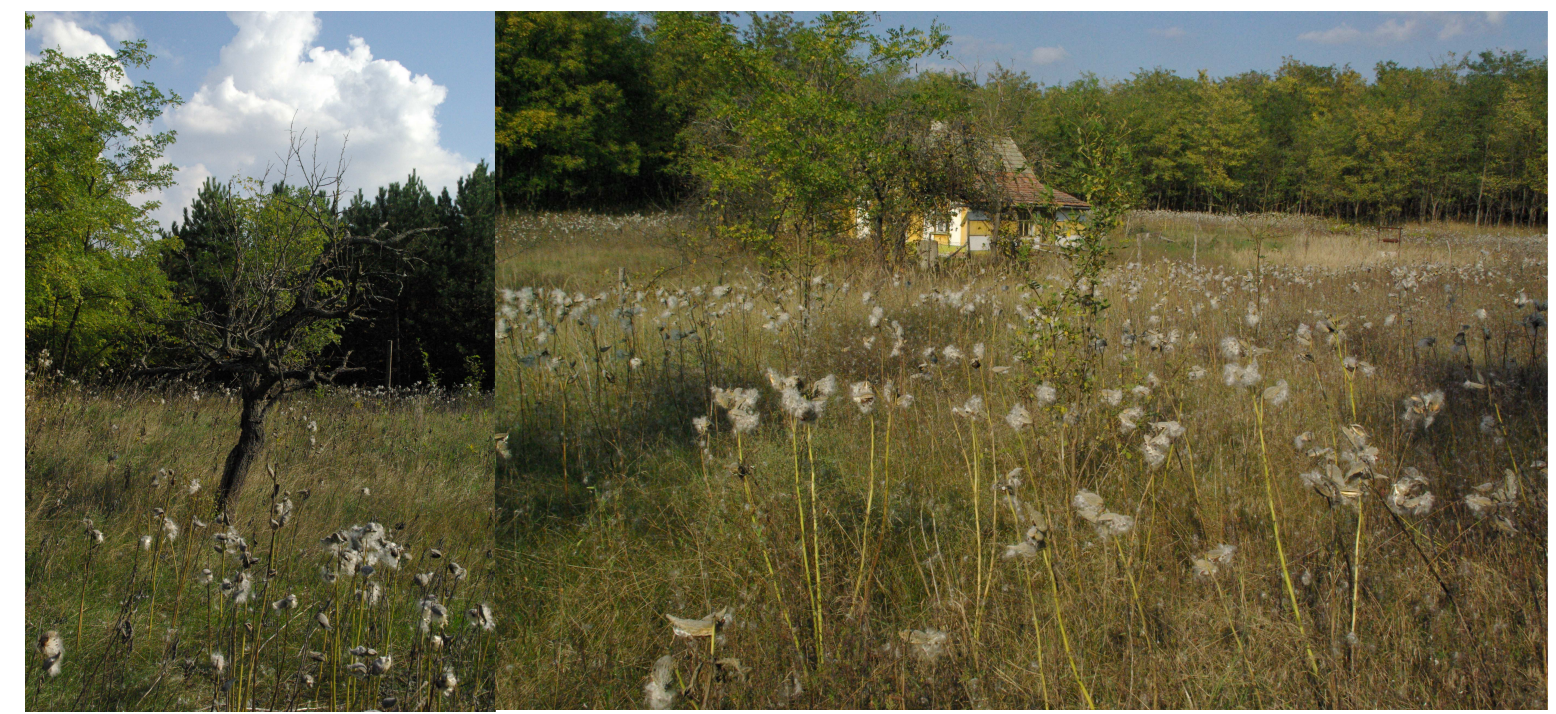

67. ábra. Kiszáradt gyümölcsfa és elnyílt selyemkóróval borított elhagyott tanya az Illancson

A gazdafórumon végzett kérdőíves kutatás alapján (23 gazda a térségből) jól látszik, hogy a termőhelyi adottságok függvényében az emberek teljesen különbözőképpen élik meg a változásokat. A térségben a homokon gazdálkodók döntő többsége a szárazodás jelenségét érzi (klímaváltozás Magyarországi következményei, csökkenő csapadék és növekvő hőmérséklet). A megkérdezettek közül az egyetlen császártöltési gazda viszont (aki valószínűleg a Duna-völgyben gazdálkodik) a klímaváltozás hatását nem tartja számottevőnek (68. ábra). 


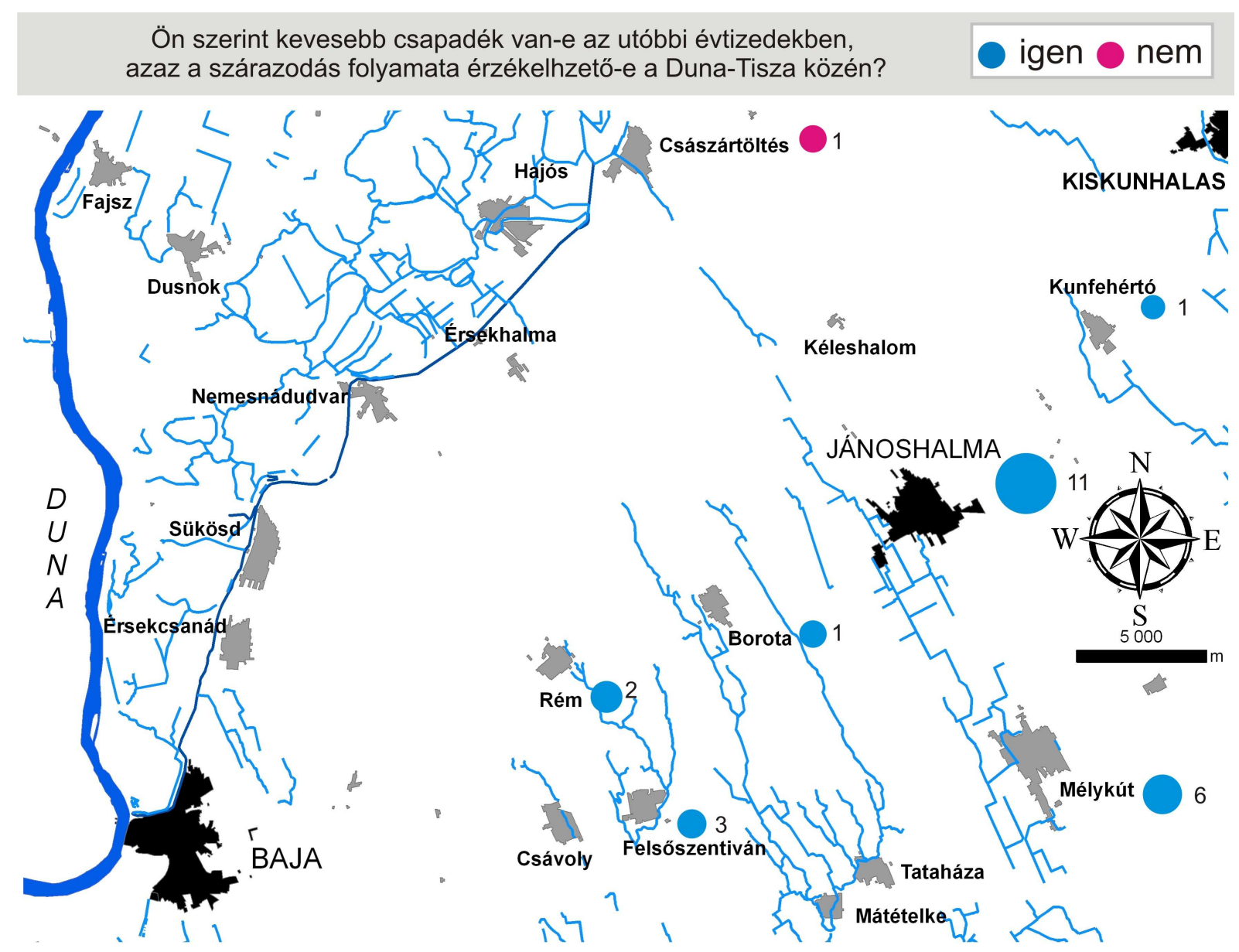

68. ábra. A jánoshalmi fórumon megkérdezett gazdálkodók lakhely szerinti megoszlása, és az szárazodásra vonatkozó kérdésre adott válaszok

A rémi, borotai, jánoshalmi gazdák (homokon gazdálkodók) egyértelmüen súlyosnak érzik a vízhiány problémáját, és ők azok, akik a vízhiány mértékét is nagyobb pontossággal tudták megbecsülni. A borotai gazda a talajvíz szintjét ma 15-20 méter mélyen becsülte, aki valószínűleg a legérintettebb zónában kényszerül gazdálkodni (lásd a 4 . fejezet 24. ábra). A szárazodás magyarországi következményeit bemutató előadásban elhangzott, hogy az 1980-as évek szénhidrogén-kutató fúrásai nem járulhattak jelentős mértékben hozzá a talajvízszint-süllyedéséhez, melyet e borotai gazda saját tapasztalatai alapján teljes mértékben cáfolt.

Modern technológiák alkalmazásával (pl. csepegtető öntözés) lehetőség nyílik a megváltozott vízviszonyokhoz való alkalmazkodásra, azonban ennek a jelentős költségnövekedésével nem sok gazda tud számolni (8. táblázat). A homoki gazdáknak a vízhiány jelentős károkat okoz, de müvelési-ág váltást kevesen tudtak végrehajtani. A művelési-ág váltást választók a nagyobb vízigényü termelési módokat (kertészet, szántó) kisebb vízigényü gabona termesztésére, illetve erdősítésre váltották fel. 
8. táblázat. Egy jánoshalmi agrárfórum (Európa Gazdaszemmel) résztvevői által kitöltött kérdöív kérdései és a rá adott igenlö válaszok (2009. 02. 26.)

\begin{tabular}{|l|c|c|}
\hline \multicolumn{1}{|c|}{ Kérdés } & $\begin{array}{c}\text { Illancsi, föként } \\
\text { homokon gaz- } \\
\text { dálkodó családok }\end{array}$ & $\begin{array}{c}\text { Környezö, jobb } \\
\text { talajadottságokkal } \\
\text { rendelkező kistájak } \\
\text { gazdálkodói }\end{array}$ \\
\hline $\begin{array}{l}\text { Rákényszerült-e müvelési ág-váltásra az el- } \\
\text { múlt évtizedekben? }\end{array}$ & $26,6 \%$ & $0 \%$ \\
\hline $\begin{array}{l}\text { Okoz -e károkat, többletköltségeket a vízhiány } \\
\text { a mezőgazdasági termelésben? }\end{array}$ & $100 \%$ & $75 \%$ \\
\hline $\begin{array}{l}\text { Tapasztalt-e környezetében példát arra, hogy a } \\
\text { vízhiány miatti terméskiesés miatt parlagon } \\
\text { hagytak területeket, illetve ezen okból költöz- } \\
\text { tek el a területről emberek? }\end{array}$ & $60 \%$ & $25 \%$ \\
\hline Öntöz-e? & & \\
\hline
\end{tabular}

A terület vízproblémáinak megoldására a válaszadók a vízvisszatartást, csatornaépítést (mint a Duna-Tisza csatorna), tározóépítést javasoltak, és csak mindössze két gazda látja megoldásként a vízutánpótlást. Amikor pedig az általunk felajánlott válaszlehetőségek közül lehetett választani tetszőlegesen, akkor a válaszadók közel 80\%-a látta lehetőségként a vízpótlást a Dunából és a Tiszából (69. ábra). A müvelési ág váltást csak nagyon kevesen (a 30 év körüli korosztályból) választották. Azt, hogy a rendszeres csatornatisztítás miért kerül a terület vízháztartás-problémájának megoldásai közé a válaszokban, talán az eddig a területen látott vízügyi gyakorlat okozta.

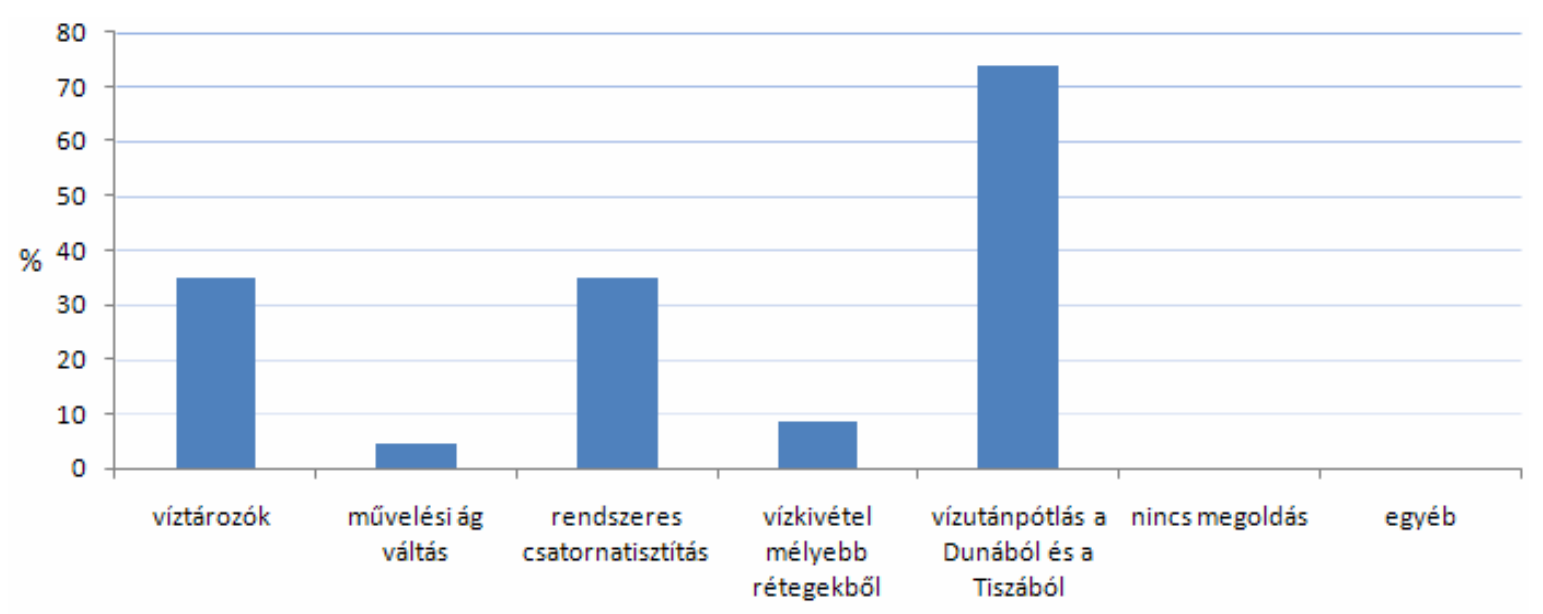

69. ábra. A vízhiány megoldására tett javaslatok

\subsection{Alkalmazkodási lehetőségek a szárazodáshoz}

A vizsgált kistáj és a Duna-Tisza közi homokhátság vízpótlása évtizedek óta foglalkoztatja a kutatókat, az államigazgatást és a vízügyi szakembereket. Azonban a mezőgazdaság számára történő vízpótlás megvalósíthatóságát a közgazdasági szempontok figyelembe vétele kétségessé teszi (a Duna szintjéhez képest minimum 40-60 m-rel kellene a vizet felemelni). 
A vízpótlást elsősorban a lehullott csapadék helybeli megőrzésével kellene megoldani, vízvisszatartással, illetve a belvízelvezetés csökkentésével. Ennek kiemelt jelentőssége lehet a buckaközi mélyedésekben húzódó üde vegetáció megóvása tekintetében. Javasolt a zsilipek elhelyezése minden olyan természetes fennmaradt élőhelyen, ahol csatorna megy keresztül. A talajvízszintek mélysége miatt átgondolandó az egyes területek tájhasználata, ahol a vízhiányhoz alkalmazkodó gazdálkodás, tájhasználat szorgalmazandó.

A fennmaradt homoki gyepeken a juhlegeltetés feltétlenül támogatandó, habár a piaci feltételek, és a mai agrárpolitika ezeknek nem kedvez. A kistáj fenntartható tájhasználatában lényeges szerepe van ennek az ágazatnak. Az erdőtelepítéseknél meg kellene engedni a ligetes erdőszerkezet kialakulását a buckás térszíneken, az erdőspuszta jellegü vegetáció kialakulása érdekében. Fontos cél lehetne, hogy a médiában megjelenő félrevezető cikkek helyett („Sivatagosodik a Kiskunság”, „Jön a sivatag”) a kutatásoknak és a tájmanagementnek a táj történetének ismeretében, annak fenntartható használatával kellene foglalkozni a jövőben.

Illancs tekintetében teljesen elvethető a Duna-Tisza csatorna és az abból való vízpótlás kérdése. A csatornával kapcsolatosan megkérdőjelezhető megvalósításának pozitív hatása a talajvízszint-süllyedés megállítására, és a tervezett nyomvonalak távolsága sem nyújthat arra reális esélyt, hogy abból a térség számára megfizethető öntözővizet lehessen nyerni. 


\section{0. ÖSSZEGZÉS}

Az elmúlt évszázadok emberi tevékenysége és az utóbbi évtizedekben sejthető klímaváltozás következményei jelentős változásokat eredményeztek Magyarországon is. Ezek a folyamatok állnak hazánk talán legismertebb vízháztartási problémája, a Duna-Tisza közén tapasztalható talajvízszint-csökkenés hátterében is. Számos konferencia és tanulmány elemezte a változások hatótényezőit, jelentőségét a politika is elismerte. A dolgozat a környezettudomány eszköztárát felhasználva az egyik legérintettebb kistáj, az Illancs környezetállapotát és az elmúlt évszázadok tájváltozásait elemezte. A kutatás eredményei a következők szerint foglalhatóak össze.

A. A mintaterület lehatárolása során kiderült, hogy a vizsgált Illancs kistáj északkeleti határvonala nem egyértelmü a szakirodalomban. A korábbi elhatárolások bizonytalanságai mögött a terület kisebb ismertsége, a tájalkotó tényezök részletes vizsgálatának hiánya és a kutatások méretarányának problémája állt. Vizsgálataim alapján az Illancs nem tekinthetö egységes kistájnak, sokkal inkább egy kistájcsoportnak, melyet a természeti adottságokban mutatkozó különbségek és az évszázadok óta eltérö tájhasználat támasztanak alá (70. ábra). A Kecel-Bajai-magaspart mentén húzódó löszperem nagy hasonlóságot mutat ugyan a Bácskai löszháttal, azonban külön kistájként való elhatárolását mérete aligha indokolja. Az elhatárolások legnagyobb bizonytalanságát jelenleg a homokterületek jelentik (leginkább a kéleshalmi homokbuckák és környezetük hovatartozása kérdéses). A különbségek feltárására a kistáj védett területeit (a kérdéses Kéleshalmi Homkbuckák Természetvédelmi Területet, valamint az Érsekhalma-Borota települések között fekvő Hajósi Homokpuszta Természetvédelmi Területet) hasonlítottam össze növényzeti, geomorfológiai, tájtörténeti vonatkozásokban. A két terület között sem fajösszetételben, sem a homokformák tekintetében nem mutatkozott jelentős különbség. A két terület eltérő fiziognómiájának oka döntően a tájhasznosításban keresendő. Egyedüli elkülönítő bélyeg a közönséges boróka (Juniperus communis) megléte lehetne a kéleshalmi homokbuckákon, azonban e fajról feljegyzések csak kb. 200 év óta állnak rendelkezésre, tehát e tényező önmagában nem szolgálhatja egyételmüen a határvonal tisztázását. Terepi vizsgálataim alapján, a jelenleg a szakirodalomban alkalmazott délkeleti határvonal is pontosításra szorulna, ugyanis a rendelkezésre álló földtani, talajtani térképek alapján a határvonal jelentős beszögellése is megkérdőjeleződött. Ez utóbbit a felszínt borító negyedidőszaki üledékek (homok-lösz) és a tájhasználat alapján pontosítottam a Rém-Jánoshalma szakaszon. A lehatárolás nehézségét a buckamezők közötti völgyeletek jelentették, ahol az egykor üde 
élőhelyek borította diszkrét mélyedések jelölték ki a tájhatárt. A ma rendelkezésre álló források és vizsgálataim alapján a kéleshalmi homokbuckák is az Illancs részét képezik, de további részletes üledékföldtani vizsgálatok szükségesek ennek pontosításához. Javaslatom, hogy a későbbiekben ezen megállapításokat a tájelhatároláskor (pl. kistáj-kataszter) vegyék figyelembe.

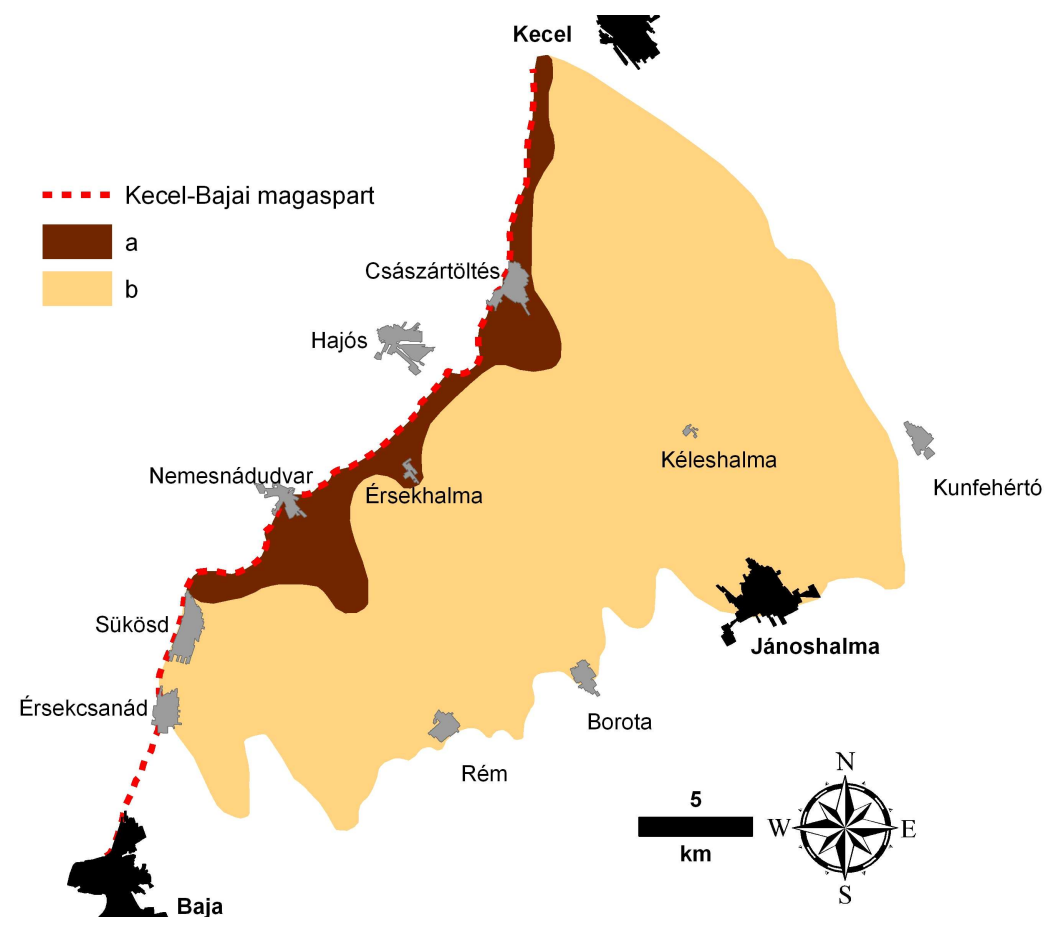

70. ábra. Illancs, mint kistájcsoport, a módosított határvonalak alapján a. Nemesnádudvar-Császártöltési löszhát b. Illancsi homokhát

B. A kistáj tájhasználatának vizsgálatával az elmúlt két évszázad jelentős tájátalakítását elemeztem, kiemelten a vízhiány kialakításában feltételezetten szerepet játszó tájhasználati kategóriák szerepét. Megállapítottam, hogy a kistáj területének 90\%-a került müvelés alá az elmúlt bö kétszáz év során. Egykori (bolygatatlan) természetes vegetációja mára csak a terület alig 1,5\%-án maradt fenn, az is jelentösen fragmentálódott és fokozottan veszélyeztetett az aridifikáció és az invazív fajok terjedése szempontjából. Az elmúlt évszázad legjelentősebb tájátalakító tevékenysége az erdősítés volt, melynek eredményeképpen Illancs egykor fátlan homoktáját ma 60\%-ban telepített erdők borítják.

Az Illancs - szükebb és tágabb elhatárolásait külön értékelve - a tájhasználatváltozás tendenciáiban nem mutatkozott különbség, csak az egyes tájhasználati kategóriák kiterjedésének százalékos arányai tértek kis mértékben el. Két évszázadra visszatekintö tájhasználat-értékelésem alapján a kistájra tájtörténeti időszakokat határoztam meg (71. ábra). 


\begin{tabular}{|c|c|c|c|}
\hline $\begin{array}{l}\text { a külterjes legeltetés } \\
\text { időszaka }\end{array}$ & $\begin{array}{l}\text { a tanyasi gazdálkodás } \\
\text { időszaka }\end{array}$ & $\begin{array}{l}\text { az intenzív erdő- és } \\
\text { mezőgazdaság időszaka }\end{array}$ & $\begin{array}{l}\text { a társadalmi átalakulás és a szárazo- } \\
\text { dás következményeinek idöszaka }\end{array}$ \\
\hline $\begin{array}{l}\text { külterjes legeltetés } \\
\text { nyílt homokpusztagyepek } \\
\text { mozgó homokfelszinek } \\
\text { kis lakónépesség }\end{array}$ & $\begin{array}{l}\text { mezőgazdasági múvelés } \\
\text { fásítás } \\
\text { szőlő- és kertkultúra } \\
\text { tanyák szaporodása } \\
\text { települések növekedése } \\
\text { komplex müvelési szerkezet } \\
\text { külterjes legeltetés }\end{array}$ & $\begin{array}{l}\text { intenzív fásítás } \\
\text { nagyüzemi szőlötermelés } \\
\text { nagytáblás mezőg-i müvelés } \\
\text { tanyák háttérbe szorulása } \\
\text { elvándorlás, városiasodás } \\
\text { természeti területek csökkenése } \\
\quad \text { (fragmentálódása) }\end{array}$ & $\begin{array}{l}\text { müvelés felhagyás } \\
\text { parlag területek szaporodása } \\
\text { invazív fajok terjedése } \\
\text { vizes élőhelyek állapotromlása } \\
\text { gazdálkodási nehézségek } \\
\text { tanyák pusztulása/újranépesedése }\end{array}$ \\
\hline 1800 & 1850 & 1950 & 2000 \\
\hline
\end{tabular}

71. ábra. Tájtörténeti időszakok az Illancson

A tájhasználat változása mellett (és ahhoz szorosan kapcsolódva) további antropogén hatásokat is értékeltem. Geomorfológiai elemzésekkel vizsgáltam a kistáj jellemző homokformáit, elemeztem és szemléltettem a planírozások és az infrastruktúra hatásait a tájra. Megállapítható, hogy a 20. század felszínátalakító tevékenysége az Illancson különösen jelentős. A szántó és szőlőmüvelés alatt álló területeken a planírozások (felszínelegyengetések) nyomán a tájra jellemző homokformák sok helyen eltüntek. A fennmaradt homoki gyepek további veszélyeztetö tényezője a gépjármüvek taposásának hatására bekövetkezö degradáció.

C. A kistáj talajvízszint-észlelő kútjainak adatai alapján elemeztem a talajvízszint változás tendenciáit, mértékét. A talajvíz-állapotok első részletes térképezése az 1950-es években az Illancson már viszonylag mélyebb vízszintet jelölt, melyet a terület domborzati helyzete támaszt alá. Az 1970-es évekhez viszonyítva az elmúlt 30 évben szinte folyamatos talajvízszint-csökkenés figyelhetö meg. E tendenciát a rövidebb nedves időszakok csak kis mértékben szakítottak meg. A 2007-es utolsó aszályos évben a talajvíztükör az Illancs legmagasabb régióiban a felszíntöl 20 méter mélyen feküdt, mely alföldi léptékben a legjelentösebb változásokat tükrözi. A terület ennek eredményeképpen a 2010-es, igen csapadékos év hatására sem volt képes igazán regenerálódni, az adatok az 1970-es évekhez viszonyítva még mindig 2-7 méter talajvízszint-süllyedést mutatnak. Mindezek azt bizonyítják, hogy rövidebb csapadékos idöszakok (nem csak az elmúlt év, hanem például az 1990-es évek vége) nem képesek a hátság teljes talajvíz-hiányát pótolni.

D. Négy mintaterületen végeztem el az Illancs üde és száraz élőhelyeinek állapotértékelését, valamint történeti térképek alapján értékeltem az elmúlt évszázadok meghatározó folyamatait. Megállapítottam, hogy a 19. és 20. század antropogén és természetes folyamatai jelentös hatással voltak az Illancs természetes és természetközeli élőhelyeire. A száraz élőhelyeken döntően a tájhasználat változás és annak következményei okoztak jelentős változásokat, valamint fragmentáltságuk jelentős veszélyeztető tényező a 21. században. A telepített erdők közé beékelődő gyepmaradványokon a száraz cserjék elöretörése, 
valamint a selyemkóróval való fertözöttség jelentös. A bolygatatlan természetes élöhelyek aránya kevés, melyeken az inváziós fertözöttség sem jelentös. A vizsgált üde élöhelyeken a zonáció kényszer-eltolódása dominál: az egykori üde élőhelyek helyét ma döntően homoki szytepprétek uraják, az egykori üde élőhelyek maradványai a mélyebb területekre (pl. csatorna) húzódtak le, ahol a lokális vízáramlási rendszerek még elegendő nedvességet biztosítanak. Ma már csak a diszkrét mélyedésekben azonosithatók a szikes és lápi élöhelyek maradványai, de a talajvízszint-süllyedés következtében ezek az élőhelyek is legtöbbször homoki sztyepprétekbe alakultak át, vagy azok sztyeppesedö változatai jelentek meg. A tájhasználatnak ma is jelentős szerepe van a tájkép alakulásában: pl. a juhlegeltetés hatására a gyepek invazív fajokkal való fertőzöttsége nem jelentős.

A leglátványosabb változások az Illancs üde élőhelyein tapasztalhatóak. A kistájon tapasztalható nagy mértékü talajvízszint-csökkenés hatása fontos mozgatója az élöhelyek átalakulásának (72. ábra).

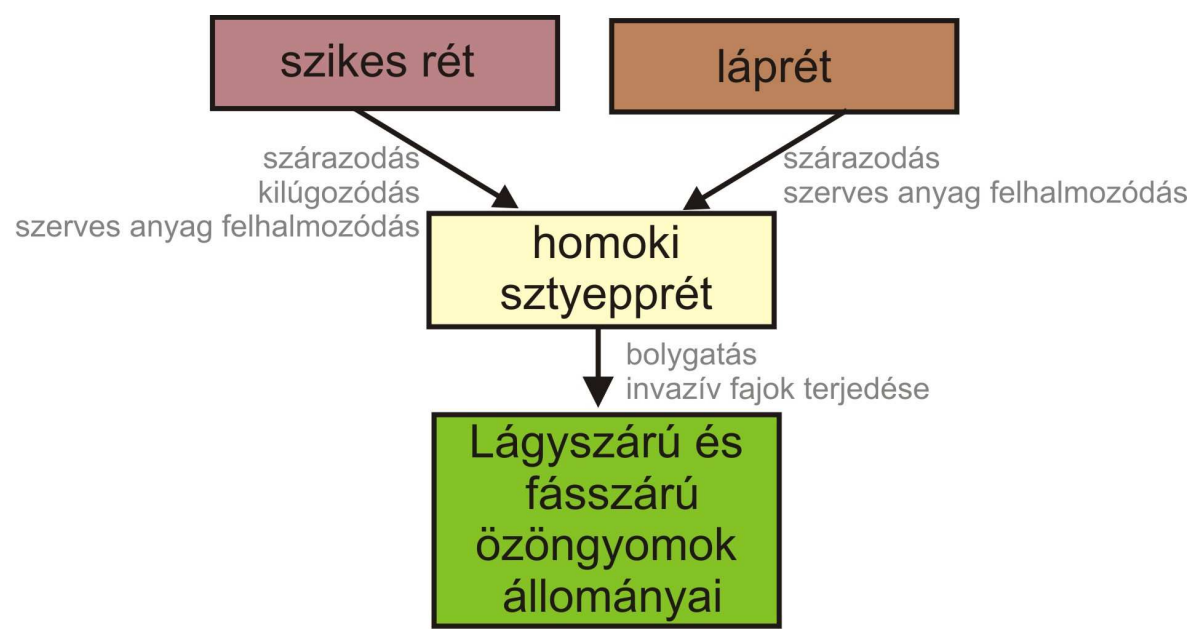

72. ábra. Illancs üde élöhelyeinek átalakulása a talajvízszint csökkenése következtében

E. A növényzet-talaj-talajvíz rendszer összefüggéseit egy természetes, egykor üde élőhelyekkel borított, jelentős részén bolygatatlan, buckamezők közötti mélyedés vizsgálata alapján elemeztem. E mintaterületet a talajtani felmérések 1949-ben szikesnek írták le. A vizsgálatok feltárták, hogy az elmúlt évtizedek drasztikus talajvízszint-csökkenése nyomán teljesen más folyamatok váltak uralkodóvá a területen, mint amelyek a vízrendezések elött e tájat meghatározták. Az egykor üde rétek dominálta mélyedésben a talajvíz jelentősen lecsökkent. Ennek eredményeképpen a területen a réties jelleg és a szikesedés helyett ma a kilúgozódás és a sztyeppesedés dominál.

Botanikai vizsgálataim igazolják az elöször a Dorozsma-Majsai Homokhátról leírt láprétfö-szikalj lokális vegetációs mintázat meglétét az Illancson. A mélyedés északnyugati 
része a talajtani és botanikai vizsgálatok eredményeit egybevetve vélhetöen sohasem volt szikes, hiszen ezt sem a mai talajtulajdonságok, sem „szikes maradványfajok” nem igazolják, ellentétben a terület délkeleti részével (,szikalj mintázat”). Korábban vélhetően a hasonló fekvés, a növényzet és a vízborítás, valamint a korlátozott számú mintavételi lehetőség miatt ítélték és írták le azonosnak a mélyedés különböző részeit.

F. A kistáj „klímaérzékenységének” vizsgálatára a csapadék és a biomasszaaktivitás kapcsolatát vizsgáltam, hiszen a drasztikus talajvízszint-süllyedés következtében a víz szük keresztmetszetként jelenik meg a növényzet számára. MODIS 16 napos kompozit képek alapján számolt vegetációs indexek alkalmazásával a fás vegetáció (telepített akác és fenyö erdők) és a csapadék erös kapcsolatát mutattam ki. Vizsgálataim alapján bebizonyosodott, hogy az illancsi akác és fenyöerdök biológiai aktivitását csak a tavasszal és nyár elején (március-június) lehulló csapadék befolyásolja, a fák így a téli csapadékot hasznositani nem tudják. A Homokhátság peremén fekvő kontrollterület esetében szintén kimutatható szoros kapcsolat a biomassza-aktivitás és a csapadék között, azonban itt a téli csapadék is befolyásoló hatásúnak bizonyult (melynek oka a talajvíz közelsége). A Duna árterén választott másik mintaterület esetében viszont nem mutatható ki szoros kapcsolat a csapadék és a biomassza-produkció között. Ebben az esetben a rendszeres áradások és a folyamatos kapcsolat a folyómederrel a kavicsos, homokos üledéken keresztül biztosít megfelelö vízmennyiséget a fáknak.

A klímaváltozásnak köszönhető csapadékhiány és a szoros kapcsolat e változó klímaelemmel a kistáj „klíma-érzékenységét” bizonyítja.

G. A probléma társadalmi vonatkozásait és a vízhiány hatását a gazdálkodásra személyes interjúk és kérdőívek alapján vizsgáltam. Terepbejárásaim során bebizonyosodott, hogy a lakosság és a gazdák a belvízelvezetö csatornákat, az 1980-as évek olajkutató fúrásait és a nagy szárazságokat okolják a terület vízháztartásbeli problémájának kialakulásáért. A kérdőívek értékelése bizonyítja, hogy a homokon élö és gazdálkodó emberek érzik a klímaváltozás hatását, gazdálkodási nehézségeik vannak, de próbálnak alkalmazkodni a megváltozott körülményekhez (müvelésiág-váltás, modern müvelési technikák). A válaszadók jelentős hányada reménykedik vízpótlásban a Dunából és a Tiszából, azaz a mezögazdaság öntözővizet vár, azonban ezen ágazat számára történő vízpótlás megvalósíthatóságát a közgazdasági szempontok figyelembe vétele kétségessé teszi. Újfajta szemléletü gazdálkodásra van szükség, melyben a fenntarthatóságra irányuló törekvések is szerepet kapnak. 
A szárazodás egy meghatározott kapcsolatrendszeren keresztül érezteti a hatását a vizsgált kistájon (72. ábra). A folyamat elemeit a klímaváltozás hazai következményeit kutató VAHAVA projekt kulcsszavai (VÁltozás-HAtás-VÁlaszadás) köré csoportosítottam.

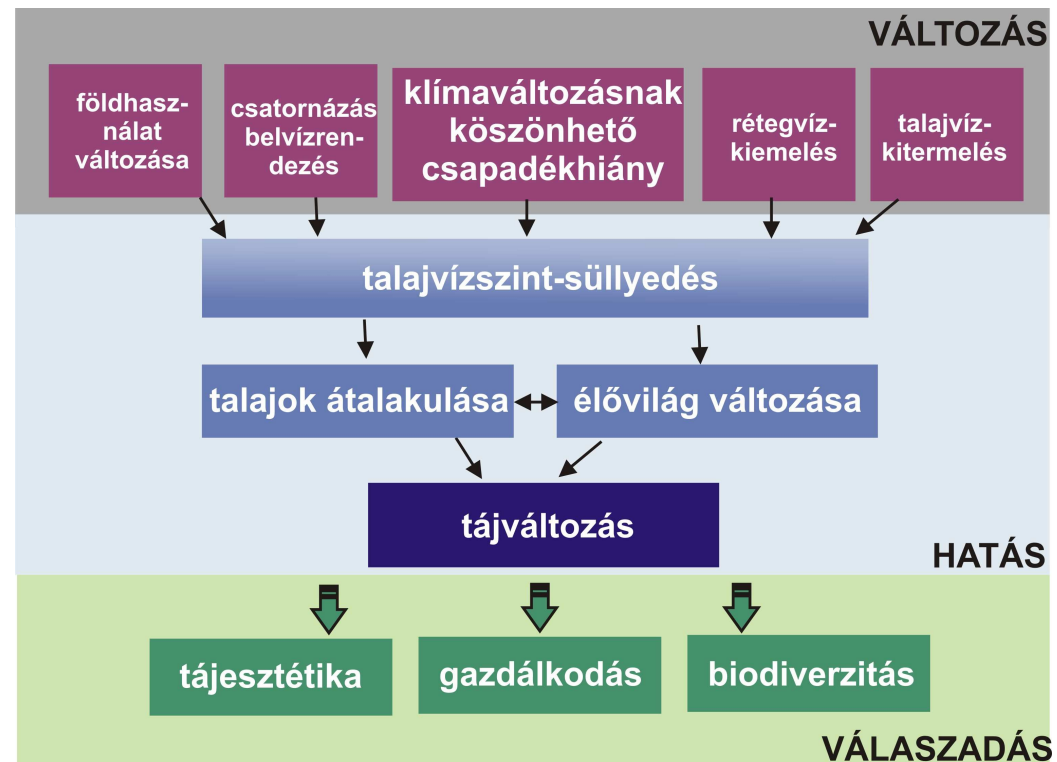

73. ábra. A szárazodás hatásának kapcsolatrendszere

Az emberi tevékenységek, valamint a klímaváltozásnak köszönhető csapadékhiány jelentős vízháztartásbeli probléma kialakulásában játszottak szerepet. Ennek következtében az élövilág és bizonyos esetekben a talaj is változik, melyeknek együttes hatására a táj átalakul. A folyamat eredményeképpen a biodiverzitás csökken, gazdálkodási nehézségek mutatkoznak, és a tájkép is jelentösen módosul a tájhasználat változásai, valamint az invazív növények jelentös terjedése következtében. 


\section{SUMMARY}

The human impact of the last centuries and the consequences of climate change presumed in the last decades have caused significant changes in Hungary as well. The groundwater-table sinking observed in the Danube-Tisza Interfluve, which is maybe the best-known hydrological problem of the country, can be explained by these processes. The causes of the changes were discussed by several conferences and studies and its significance was recognised by the politics. In this study the environmental conditions of the Illancs microregion, highly affected by this process, and the landscape changes in the last centuries were evaluated, using diverse methods of environmental sciences. The results of the research can be summarised as it follows.

A. The north-eastern border of the examined microregion proved to be ambiguous in the literature. The obscureness of the former demarcations was caused by the slight knowledge about this microregion, the lack of the detailed research of the landscape factors, as well as the scale of the previous surveys. According to my research, the Illancs can not be considered as a homogenous microregion but a microregion-group, which is confirmed by the differences of natural attributes and the diverse landuse for centuries (Figure 70). The highest obscureness of the demarcation is shown by the sand-covered areas (mainly the affiliation of dunes near Kéleshalom settlement is questionable). In order to reveal the differences (or similarities) of the disputed parts, the protected areas (the Kéleshalmi Homokbuckák Nature Reserve and the Hajósi Homokpuszta Nature Reserve between Borota and Érsekhalom settlements) were compared in respect of vegetation, geomorphology and landscape history. Significant differences could not be identified between the examined sample areas, in all respects. The different physiognomies of the areas can be explained by the former landuse. The only separating factor can be the presence of Juniperus communis in Kéleshalmi Homokbuckák Nature Reserve, but data about this species has been available for 200 years. Thus, this fact itself can not make the proper boundary clear. Based on my fieldworks, the south-eastern border should be refined as well, mostly in case of a huge indenture near Borota, which can not be explained by the available soil science and geological maps. This border was refined along a section between Rém and Jánoshalma settlements, based on quaternary sediments (sand-loess) and landuse. The blowouts between the dune zones showed difficulties in the demarcation, where the depressions former dominated by wet habitats marked the border. 


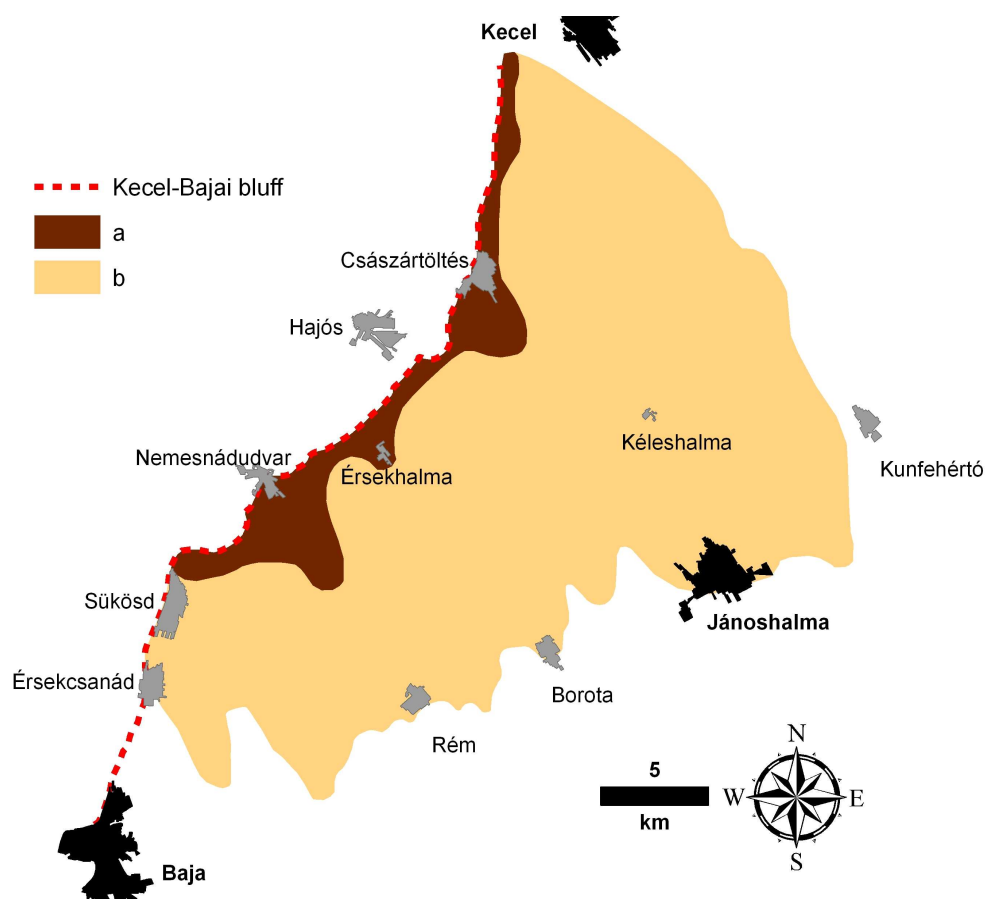

Figure 70. Illancs as a microregion group, with the modified border a. Nemesnándudvar-Császártöltési Loess Plateau b. Illancsi Sandland

Based on the available map-, database sources and my investigations, the dunes around Kéleshalom settlement are the part of Illancs, but further detailed sedimentological investigations are needed for the proper separation. Consequently, I suggest the above mentioned facts to be considered in case of a new microregion-cathaster.

B. The significant landscape changes of the last two centuries were evaluated by the analysis of landuse in the microregion, emphasizing the landuse cathegories that can play role in the formation of the water-shortage. $90 \%$ of the territory of the microregion was found to become cultivated in the last two hundred years. The former natural vegetation has remained only in $1.5 \%$ of the area, it is fragmented and highly endangered by the aridification and the spread of invasive species. The most significant activity affecting the natural landscape was the forestation. As a result of this process, $60 \%$ of the examined microregion (former determined by moving sanddunes, open sand steppes) is covered by planted forests.

By investigating the landuse changes in case of the narrower and the wider landscape-border, the tendencies did not differ significantly, only the extent values showed sometimes slightly differences. Based on my evaluation on landuse-changes, landscape historical periods were determined for the microregion (Figure 71.). 


\begin{tabular}{|c|c|c|c|}
\hline $\begin{array}{l}\text { Period of extensive } \\
\text { grazing }\end{array}$ & Period of farming in hamlets & $\begin{array}{l}\text { Period of intensive forest- and } \\
\text { arable land management }\end{array}$ & $\begin{array}{l}\text { Period of social changes and the } \\
\text { consequences of climate change }\end{array}$ \\
\hline $\begin{array}{l}\text { extensive grazing } \\
\text { opened sand steppes } \\
\text { moving sand-dunes } \\
\text { few inhabitants }\end{array}$ & $\begin{array}{l}\text { arable lands } \\
\text { forestation } \\
\text { small viticultures } \\
\text { growing number of hamlets } \\
\text { forming settlements } \\
\text { extensive grazing } \\
\text { complex cultivation structure }\end{array}$ & $\begin{array}{l}\text { intensive forestation } \\
\text { industrial agriculture } \\
\text { large monocultures } \\
\text { hamlets get into the background } \\
\text { migration, urbanisation } \\
\text { decrease (and fragmentation) } \\
\text { of natural areas }\end{array}$ & $\begin{array}{l}\text { abandoned arable lands } \\
\text { increase of regenerating waste lands } \\
\text { spread of invasive species } \\
\text { drying wetlands } \\
\text { difficulties in farming } \\
\text { destruction/repopulation of hamlets }\end{array}$ \\
\hline 1800 & 1850 & 1950 & 2000 \\
\hline
\end{tabular}

Figure 71. Landscape historical periods on the Illancs microregion

Beside (and in strong connection with) the evaluation of landuse-changes, further antropogenic effects were also described. By geomorphological evaluations, the sandforms of the microregion were analysed, the effects of the planation and the infrastructure on the landscape were demonstrated. It can be claimed, the effect of the 20th century on the surface sandforms proved to be highly significant. Due to cultivation and viticultures (and the related planations), the characteristic forms has disappeared on many places. The further endangering factor of the remained sand steppes is the degradation due to the treading effect of vehicles.

C. On the basis of groundwater-table data of the groundwater-wells in the microregion, the tendencies and the degree of groundwater change were analysed. The first mapping of groundwater-depth in the 1950s showed deeper groundwater-level in the Illancs, which can be confirmed by the location and the relief of the microregion. Compared to the 1970s, a continuous decreasing process can be observed in the last 30 years, which tendency was hardly interrupted by short humid periods. In the last arid year (in 2007) the groundwater-table was 20 metres under the surface in the highest regions of Illancs microregion, which reflects the most significant changes in the Great Hungarian Plain. The territory could not regenerate due to the high amount of precipitation in 2010; the data still show 2-7 metres decrease compared to the 1970s. All these confirm the fact that short humid periods (not only the last year, but for example the end of the 1990s) can not contribute to the total refill of groundwater resource in the whole Danube-Tisza Interfluve. I

D. The condition of dry and wet habitats in Illancs was investigated in four sample areas and the determining processes of the last decades were evaluated based on historical maps. Anthropogenic and natural processes of the $19^{\text {th }}$ and $20^{\text {th }}$ century exerted significant influence on natural and semi-natural habitats in Illancs. In dry habitats mainly landuse changes and their consequences caused significant alterations, and their fragmentation is an endangering factor in the $21^{\text {st }}$ century. In these remained meadows between planted forests, the spread of dry shrubs and the infection with Asclepias syrica is significant. The 
ratio of natural vegetation without disturbance is slight where the presence of invasive species is less significant. In the examined wet habitats the shift of vegetation zones can be observed. The former wet habitats were replaced with sand steppe grasslands and wet habitats receded into deeper location (e.g. channel), where the local water-flow systems could ensure them enough moisture. Nowadays, the remains of wet and saline habitats can be identified just in the depressions where mainly their steppificated varieties occur due to the deeper groundwater. On the other places they have transformed into sand steppe grasslands Landuse has significant landscape-forming effect: for example due to grazing with sheep, the infection by invasive species of meadows is less significant. The most considerable changes can be observed in case of wet habitats in the microregion. The effect of the groundwater-sinking process is an important impulsive force in the alteration of habitats (Figure 72).

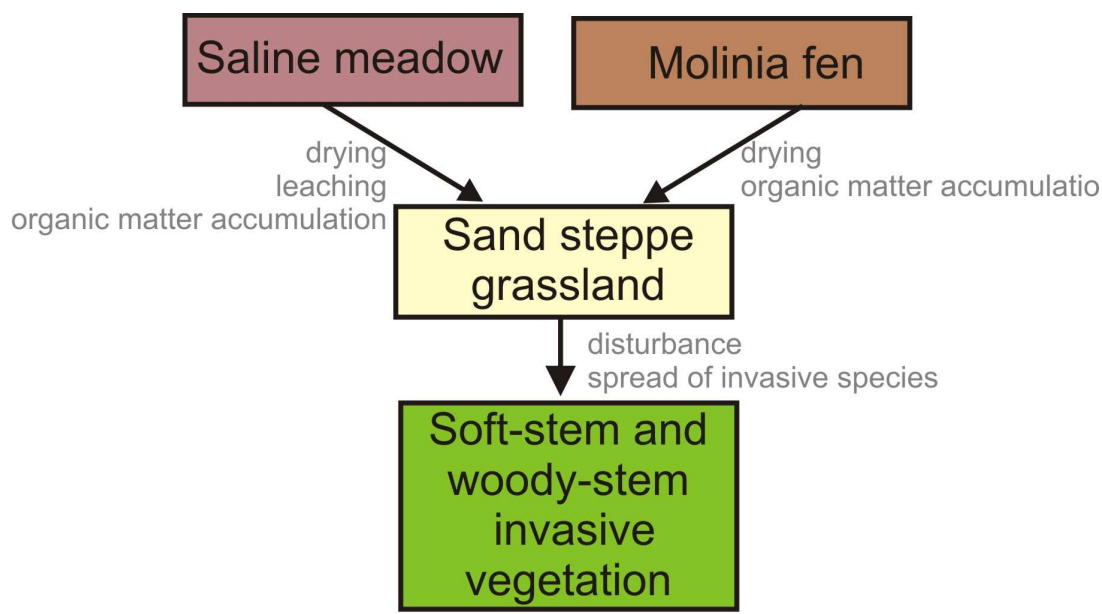

Figure 72. Alteration of wet habitats due to groundwater-table sinking in Illancs microregion

E. The coherences of the vegetation-ground-groundwater system were studied with the help of a barely undisturbed deflation hollow with former wet habitats, which was described by saline soil type by the soil mapping in 1949. My investigations revealed that due to the critical groundwater-sinking of the last decades, other processes became dominant in the area that had been determining the landscape before the canalisation. The soils of the deflation hollow covered previously wet meadows have not been affected by groundwater any more. As a result of this, leaching and steppification dominates instead of meadow characteristic and salinization (sodification).

The botanical investigations proved the presence of the 'fen-head-saline-foot' local vegetation pattern in the Illancs microregion, first described in the Dorozsma-Majsa Sandland. Compared my botanical investigations to soil science ones, the north-eastern part of the examined deflation hollow has never been saline since neither the present soil parame- 
ters now nor 'remained saline species' has referred to previous saline conditions contrary to the southern part of the sample area ('saline-foot' pattern). Presumably due to the similar relief, the vegetation, the water-cover and the limited number of sampling, the different parts of the deflation hollow were described similarly.

F. To investigate the 'climate-sensitiveness' of this microregion, the relation of precipitation and biomass-activity was examined since water appears as a 'bottleneck' for the vegetation over the significant groundwater-sinking. Based on vegetation index values of MODIS 16-day-composite images, the close relation between forest (planted locust and pine) and the precipitation were determined. Biological activity of locust and pine forests in Illancs microregion proved to be affected by the precipitation in spring and early summer (from March to June) so the trees can not utilize the winter precipitation. In the case of the control site on the edge of the Sandland, the close relation between biomass-activity and precipitation can be defined as well, but here winter precipitation proved to be relevant owing to near-by groundwater. However, there is no connection between precipitation and biomass on the other control site in the Danube-valley. In this case the regular floods and the continuous connection with the riverbed through the sandy, pebbly silt ensure sufficient water for the trees. The precipitation shortage due to climate change and the close relation with this variable climate factor proves the 'climate-sensitiveness' of Illancs.

G. The social relations of the problem and the effect of water-shortage on farming were evaluated by personal interviews and questionnaires. According to our field interviews, the farmers blame the channels, the oil research drillings in the 1980s and the heavy droughts for the formation of water shortage. The evaluation of the questionnaires proves that people living and farming on sandy soils feel the consequences of climate change. They have difficulties in farming but they try to adapt to the changed conditions (e.g. landuse changes, modern technologies). Majority of the questioned people hopes in watersupplement from the River Danube and the River Tisza so agriculture expects irrigation water. However, the realisation of water-supplement for this sector is doubtful regarding to the economical aspects. The farming is in bad need in new approach with guidelines of sustainability.

Aridification affects, through a certain connection-system, on the microregion (Figure 73). The elements of the process were grouped according to the keywords of the VAHAVA program (Change - Effect - Reaction) investigating the consequences of climate change in Hungary. 


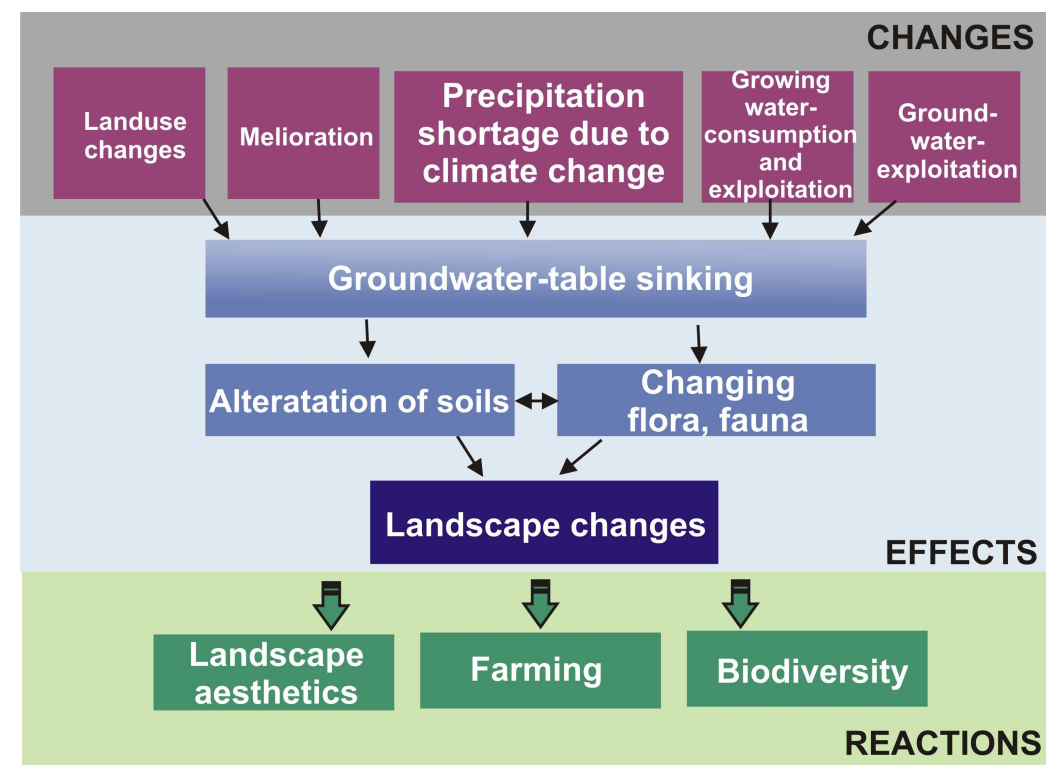

Figure 73. The connection-system of the effects of aridfication

Human activities and precipitation shortage due to climate change played important role in the formation of a significant hydrological problem. Thus, the changes of flora, fauna and in certain cases soils together contribute to the landscape change. As a result of this process biodiversity decreases, farming difficulties appear and landscape alters due to landuse changes and the intensive spread of invasive species. 


\section{Köszönetnyilvánítás}

Ezúton szeretnék köszönetet mondani témavezetőmnek, Dr. Rakonczai Jánosnak az elmúlt években adott hasznos tanácsaiért, támogatásáért és útmutatásáért.

Köszönetemet fejezem ki a Természeti Földrajzi és Geoinformatikai Tanszéknek, hogy lehetőséget biztosított számomra kutatásom megvalósításához, illetve valamennyi munkatársamnak, hogy az elmúlt évek alatt hasznos tanácsokkal, észrevételekkel segítették a munkámat.

Külön köszönöm Dr. Deák József Áronnak a terepi felvételezésekben nyújtott segítségét és ötleteit, Boudewijn van Leeuwennek hasznos tanácsait a geoinformatikai elemzésekben, valamint Dr. Kuti Lászlónak a földtani vizsgálatokhoz nyújtott támogatását.

Köszönettel tartozom az Illancs területén élő gazdálkodóknak is, akik pozitív hozzáállásukkal, véleményeikkel, ismereteikkel nagyban segítették a munkámat.

Köszönöm a családom és a barátaim türelmét és támogatását, melyet munkám során tanúsítottak, létrejöttét elősegítették és szorgalmazták.

Végezetül köszönöm a TÁMOP-4.2.1/B-09/1/KONV-2010-0005 azonosító számú, „Kutatóegyetemi Kiválósági Központ létrehozása a Szegedi Tudományegyetemen” címü projekt támogatását. 


\section{IRODALOMJEGYZÉK}

Ahl, D.E - Gower, S.T. - Burrows, S.N. - Shabanov, N.V. - Myneni, R.B. - Knyazikhin, Y. (2006): Monitoring spring canopy phenology of a deciduous broadleaf forest using MODIS. Remote Sensing of Environment, 104, pp. 88-95.

Almási I. (2001): Petroleum Hydrgeology of the Great Hungarian Plain, Eastern Pannonian Basin, Hungary. PhD thesis, University of Alberta, Canada, 312 p.

Arnold E. - Knipl I. (2003): Fejezetek Császártöltés történetéböl és néprajzából. ISBN 963-4305-38-5. 141.p.

Aszály és Szárazodás (2009): Aszály és Szárazodás Magyarországon Konferencia, 2009.10.07. Kecskemét

http://www.vahavahalozat.hu/files/Kecskemet/\%C3\%8111\%C3\%A1sfoglal\%C3\%A1s.pdf

Bádonyi K. (2001): A tájdegradáció napjainkban. Földrajzi Értesítő 50. pp. 321-334.

Baret, F. - Guyot, G. (1991): Potentials and limitsof vegetation indices for LAI and APAR assessment. Remote Sensing of Environment, 35, pp. 161-173.

Barczi A. - Grónás V. - Penksza K. (1996): A tihanyi táj változásai a századforduló óta. Agrártört. Szemle, 38, pp. 298-316.

Barna Gy. (2010): Tájváltozás vizsgálata a Szabadkígyósi-pusztán. In: Szilassi P. - Henits L. (szerk.): Tájváltozás értékelési módszerei a XXI. Században. Tudományos konferencia és műhelymunka tanulmányai, Szeged. pp. 207-215.

Bartholy J. - Mika J. - Pongrácz R. - Schlanger V. (2005): A globális felmelegedés éghajlati sajátosságai a Kárpát-medencében. In: Takács-Sánta A. (szerk.) Éghajlatváltozás a világban és Magyarországon. Alinea Kiadó - Védegylet, Budapest, pp. 105-139.

Bartholy J. - Pongrácz R. (2008): Regionális éghajlatváltozás elemése a Kárpát-medence térségére. In: Harnos Z. - Csete L. (szerk.). Klímaváltozás: környezet - kockázat társadalom. Szaktudás Kiadó Ház Zrt. pp. 15-53.

Basist, A. - Grody, N.C. - Peterson, T. C. - Williams, C. N. (1998): Using the Special Sensor Microwave/Imager to monitor land surface temperatures, wetness, and snow cover. J. Appl. Meteorol., 37, pp. 888-911.

Bauer, L. - Weinitschke, H. (1976): Tájrendezés. Mezőgazdasági Kiadó, Budapest. 254 p.

Beluszky P. (2001): A Nagyalföld történeti földrajza. Dialog Campus Kiadó, Budapest, 274 p.

Berényi P. - Erdélyi M. (1990): A rétegvíz szintjének süllyedése a Duna-Tisza közén. Vízügyi Közlemények, 72 (4), pp. 377-397. 
Beven, K.J. - Kirkby, M.J (1979): A physically based variable contributing area model of basin hydrology. Hydrol. Sci. Bull., 24, pp. 43-69.

Bíró M. (2006): A történeti térképekre alapuló vegetációrekonstrukció és alkalmazásai a Duna-Tisza közén. PhD értekezés, Pécsi Tudományegyetem, 139 p.

Biró M. - Molnár Zs. (1998): A Duna-Tisza köze homokbuckásainak tájtípusai, azok kiterjedése, növényzete és tájtörténete a 18. századtól. Történeti Földrajzi Füzetek, 5, pp. 1-34.

Biró M. - Révész A. - Molnár Zs. - Horváth F. (2007): Regional habitat pattern of the Danube-Tisza interfluve in Hungary I. The landscape structure and habitat pattern; the fen and alkali vegetation. Acta Bot. Hung., 49 (3-4), pp. 267-303.

Biró M. (2008): A Duna-Tisza köze fásszárú vegetációjának átalakulása a 18. század óta, különös tekintettel a száraz homokterületekre. In: Kröel-Dulay Gy. - Kalapos T. Mojzes A. (szerk): Talaj-vegetáció-klíma kölcsönhatások. Köszöntjük a 70 éves Láng Editet. MTA Ökológiai és Botanikai Kutatóintézete, Vácrátót, pp. 23-38.

Bognár P. (2004). Müholdas termésbecslési eljárások fejlesztése. Doktori (PhD) értekezés. ELTE. 136 p.

Boros E. - Biró Cs. (1999): A Duna-Tisza közi szikes tavak ökológiai állapotváltozásai. Acta Biol. Debr. Oecol. Hung., 9, pp. 81-105.

Borsy Z. (1977): A Duna-Tisza közi hátság homokformái és a homokmozgás szakaszai. Alföldi Tanulmányok 1. pp. 43-54.

Borsy Z. (1989): Az Alföld hordalékkúpjainak fejlődéstörténete. Földrajzi Értesítő, 38. (3-4). pp. 211-224.

Borsy Z. - Fészerfalvi J. - Lóki J. (1981): A Jánoshalmi MÁFI alapfúrás homoküledékeinek elektronmikroszkópos vizsgálata. Acta Geographica Debrecina, 20, pp. 35-50.

Bölöni J. - Molnár Zs. - Kun A. - Biró M. (2007): Általános Nemzeti Élőhelyosztályozási Rendszer (Á-NÉR) (Hungarian National Habitat Classification System). Institute of Ecology and Botany, Hungarian Academy of Sciences, Vácrátót, 184 p.

Bulla B. (1962): Magyarország természeti tájai. Földrajzi Közlemények, 10, pp. 1-16.

Bulla B. - Mendöl T. (1947): A Kárpát-medence földrajza. Budapest, Országos Köznevelési Tanács $611 \mathrm{p}$.

Burai P. - Tamás J. (2005): Talajdegradációs folyamatok vizsgálata nagy felbontású távérzékelt adatforrások alapján. Agrártudományi Közlemények, 16, pp. 145-148.

Buzetzky Gy. - Zsuffa I. (1976): Természetvédelmi területek vízrendezésének hidrológiai előkészítése. Hidrológiai Közlöny, (56) 7, pp. 311-319. 
Czinege A. - Kiss A. - Horváth M. (2004): Elhagyott teraszok és a történeti tájhasználat rekonstrukciós lehetőségei: A nagymarosi teraszrendszer példája. In: Barton G. Dormány G. (szerk.): A magyar földrajz kurrens eredményei. Szeged, SZTE TTK Természeti Földrajzi és Geoinformatikai Tanszék ISBN 963-482-687-3.pp. 1-12.

Csatári B. (1995): Az Alföld helyzete és perspektívái. Alföld Kutatási Program 19911994. A Nagyalföld alapítvány kötetei 4. 99 p.

Csatári B. (2004): Indulatos írás a Duna-Tisza közi Homokhátság ügyéről. In: Csatári B. (szerk.): Homokhátság: Szembesítések, lehetőségek, teendők. MTA RKK ATI http://www.alfoldinfo.hu/homokhatsag/homokhatsag.html

Csatári B. (2006): Táj, társadalom, tanya...térbeli és időbeli változások a Kiskunságban.In: Szentesi Á. - Növényi G. - Török J.(szerk.) 7. Magyar Ökológus Kongreszszus. Előadások és poszterek összefoglalói, Budapest, ELTE TTK, 42 p.

Csatári B. - Csordás L. (1994): A Duna-Tisza közi hátság településfejlődése és hatásai a vízháztartásra. A Nagyalföld Alapítvány Kötetei 3, pp. 33-36.

Csecserits A. - Botta-Dukát Z. - Rédei T. - Kröel-Dulay Gy. - Szabó R. - Szitár K. -Czúcz B. (2010): Van-e kapcsolat a táji környezet és a parlagfü különböző élőhelyeken való jelenléte közt a Kiskunságban? IV. Tájökológiai konferencia, konferenciakötet (in press).

Cserni I. - Füleky G. (2008): A Duna-Tisza közi homokhátság talajainak vízgazdálkodása. Talajvédelem, pp. 53-63.

Csorba P. (1996): Landscape-ecological change of the land use pattern on the east foothill area of Tokaj Mountains (Hungary). Ecologia (Bratislava) 15, pp. 115-127.

Csorba P. (1999): Tájökológia. Kossuth Egyetemi Kiadó. Debrecen. 113 p.

Csorba P. (2005): Magyarország út- és vasúthálózatának ökológiai tájfragmentációs hatása. ÖKO XIII. (3-4), pp. 102-112.

Csorba P. (2006): Indikátorok az ökológiai tájszerkezet és tájműködés vizsgálatához. In: Kiss A. - Mezősi G. - Sümegi Z.(szerk.): Táj, környezet és társadalom. Ünnepi Tanulmányok Keveiné Bárány Ilona professzor asszony tiszteletére. Szeged, pp. 117-122.

Csorba P. (2008): Tájhatárok és foltgradiensek. In: Csima P. - Dublinszki-Boda B. (szerk.): Tájökológiai kutatások. pp. 83-90.

Csorba P. - Szabó Sz. - Csorba K. (2006): Tájmetriai adatok tájökológiai célú felhasználása. In: Demeter G. (szerk): Földrajzi tanulmányok Dr. Lóki József tiszteletére, Debrecen, pp. 24-34.

Csordás L. - Csatári B. (1990): Népesség és településföldrajzi változások és azok hatása a vízkivételre a Duna-Tisza közén. Kutatási Jelentés, Kecskemét. 
Csornai G. (2001): Termésbecslés ürfelvételekkel. Természet Világa (132) 2. pp.5-8.

Deák J. Á. (2004): Tájváltozásvizsgálatok élőhelytérképezés segítségével Csongrád és Szeged városok környékén. II. Magyar Földrajzi Konferencia, Szeged. Online at: http://geography.hu/mfk2004/mfk2004/cikkek/deak_jozsef_aron.pdf

Deák J. Á. (2006): Morfológia-talaj-növényzet kapcsolatának mintázat-vizsgálata a Dorozsma-Majsai-homokháton. In.: Kiss A. - Mezősi G. - Sümeghy Z. (szerk.) Táj, környezet és társadalom. Ünnepi Tanulmányok Keveiné Bárány Ilona professzor aszszony tiszteletére. pp. 123-131.

Deák J. Á. (2010): Csongrád megye kistájainak élőhelymintázata és tájökológiai szempontú értékelése. PhD értekezés. Szeged, 266 p.

Dobson, E. é.n.: Water Mask modell. http://www.erdas.com

Dóka R. - Alexa R. - Kőhalmi F. - Keveiné Bárány I. (2006): A vizes élőhelyek és a szántógazdálkodás tájhasználati konfliktusa a Duna-Tisza közén. In: Kiss A. - Mezősi G. - Sümegi Z.(szerk.): Táj, környezet és társadalom. Ünnepi Tanulmányok Keveiné Bárány Ilona professzor asszony tiszteletére. Szeged, pp. 155-165.

Dóka R. (2009): A tájváltozások és a társadalmi-gazdasági viszonyok alakulásának összefüggései a Duna-Tisza köze középső részén. In: Szilassi P. - Henits L. (szerk.): Tájváltozás értékelési módszerei a XXI. században. Tudományos konferencia, és mühelymunka, Szeged. pp. 159-179.

Dövényi Z. (szerk.) (2010): Magyarország kistájainak katasztere. MTA FKI, Budapest. 876 p.

Duray B. (2009): Tájdinamikai vizsgálatok - a tájhasználat-változás és regenerációs potenciál összefüggéseinek modellezése. PhD értekezés, Szeged. 136 p.

Duró A. (2005): A tanyai társadalom. In: Takács A.(szerk.): Tanyakutatás. Kutatási füzetek 3. pp. 2-21.

Evrendilek, F. - Gulbeyaz, O. (2008): Deriving Vegetation Dynamics of Natural Terrestrial Ecosystems from MODIS NDVI/EVI Data over Turkey. Sensors, 8, pp. 5270-5302.

Farkas A. (2004): Szülőfalum (Borota) földrajzi nevei. Szakdolgozat. Eötvös József Főiskola, Pedagógiai Fakultás, Baja. 35 p.

Franyó F. (1988): A Jánoshalma Jh. 1. sz. alapfúrás földtani és vízföldtani eredményei. A Magyar Állami Földtani Intézet évi jelentése az 1986-os évről. pp. 327-357.

Franyó F. (1994): Magyarország negyedidőszaki üledékeinek vastagság térképe. Méretarány: 1:500 000, MÁFI, Budapest.

Frisnyák S. (1990): Magyarország történeti földrajza. Tankönyvkiadó, Budapest, 213 p. 
Fügedi U. - Pocsai T. - Kuti L. (2005): Agro-geochemical problems in the soil-parent rock-groundwater system. Geophysichal Research Abstracts. 7. 07245. EGU General Assembly 2005, Vienna.

Földrajzi kistájak é.n. http://www.novenyzetiterkep.hu/?q=magyar/node/407

Gábor P. - Jombach S. - Ongjert R. (2006): Budapest zöldfelületi állapotfelmérése ürfelvételek feldolgozásával. 4D: Tájépítészeti és kertmüvészeti folyóirat, 4. pp. 14-22.

Gilabert, M.A. - González-Piqueras, J. - Garcia-Haro, F.J. - Meliá, J. (2002): A generalized soil-adjusted vegetation index. Remote Sensing of Environment, 82, pp. 303-310.

Góczán L. (1961): Vita Magyarország természeti földrajzi tájbeosztásáról. Földrajzi Értesítő 10 (2), pp. 258-264

Gong, P. - Pu, R. - Biging, G.S. - Larrieu, M.R. (2003): Estimation of forest leaf area index using vegetation indices derived from hyperion hyperspectral data. IEEE Transactions on Geoscience and Remote Sensing, 40, pp. 1355-1362.

Gyirán I. (2009): A Duna-Tisza közi homokhátság vízgazdálkodásának fenntartható fejlesztése (Müszaki lehetőségvizsgálat). A Magyar Hidrológiai Társaság XXVII. Országos Vándorgyülése. http://www.hidrologia.hu/vandorgyules/27/dolgozatok/02gyiran_istvan.htm

Hardisky, M.A. - Klemas, V. - Smart, R.M. (1983): The influence of soil salinity, growth form, and leaf moisture on the spectral radiance of Spartina alterniflora canopies. Photogrammetric Engineering and Remote Sensing, 49, pp. 77-83.

Harmati I. (1994): A Duna-Tisza köze vízháztartása és a mezőgazdasági tevékenységek közötti kölcsönhatások. A Nagyalföld Alapítvány Kötetei 3. pp. 37-52.

Harnos Zs. - Gaál M. - Hufnagel L. (2008): Klímaváltozásról mindenkinek. Budapesti Corvinus Egyetem, Kertészettudományi Kar, Matematikai és Informatikai Tanszék, Bp. $199 \mathrm{p}$.

HDF-EOS 2010: HDF-EOS Tools and Information Center, http://hdfeos.org/index.php (Megtekintve: 2010. 06. 16.)

Horváth A. (2004): Az Illancs löszvegetációjának összehasonlító növényföldrajzi és cönológiai értékelése. Aktuális Flóra- és Vegetációkutatás a Kárpát-medencében VI, Keszthely, p. 30

Hoyk E. (2005): A szárazodás hatása a vegetáció alakulására Homokhátsági szikes tavak példáján. In: Kiss A. - Mezősi G. - Sümeghy Z. (szerk.): Táj, környezet és társadalom. Ünnepi Tanulmányok Keveiné Bárány Ilona professzor asszony tiszteletére. pp. 293-303.

Huete, A. R. (1988): A soil-adjusted vegetation index (SAVI). Remote Sensing of Environment, 25, pp. 295-309. 
Huete, A. - Justice, C. - Liu H. (1994): Development of vegetation and soil indices for MODIS-EOS. Remote Sensing of Environment, 49, pp. 224-234.

Huete, A. - Justice, C. - van Leeuwen, W. (1999): MODIS VI atbd (MOD 13)

Algorithm Theoretical Basis Document, Version 3. Online at:

http://modis.gsfc.nasa.gov/data/atbd/atbd_mod13.pdf

Huete, A. - Didan, K. - Miura, T. - Rodriguez, E.P. - Gao, X. - Ferreira, L.G. (2002): Overview of the radiometric and biophysical performance of the MODIS vegetation indices. Remote Sensing of Environment, 83 (1-2), pp.195-213.

Huete, A.R. - Didan, K. - Shimabukuro, Y.E. - Ratana, P. - Saleska, S.R. - Hutyra, L.R. - Yang, W. - Nemani, R.R. - Myneni, R. (2006): Amazon rainforests greenup with sunlight in dry season, Geophysical Research Letters, 33. L06405

Illyés Zs. (1997): Tájváltozási folyamatok Magyarországon. A területhasználat és a tájszerkezet alakulása a honfoglalástól napjainkig. Kandidátusi értekezés. Kertészeti Egyetem, Tájvédelmi Tanszék, Budapest, 147 p.

Iványosi Szabó A. (1994): A Duna-Tisza közi hátságon bekövetkezett talajvízszintsüllyedés hatása természetvédelmi területeinkre. In Pálfai I (szerk.): A Nagyalföld Alapítvány kötetei 3. A Duna-Tisza közi hátság vízgazdálkodási problémái. pp. $77-85$.

IPCC (2007): Climate Change 2007: Synthesis Report. Contribution of Working Groups I, II and III to the Fourth Assessment Report of the Intergovernmental Panel on Climate Change [Core Writing Team, Pachauri, R.K and Reisinger, A. (eds.)]. IPCC, Geneva, Switzerland, 104 p.

Jackson, R.D. (1982): Canopy temperature and crop water stress, Advances in irrigation, 1, pp. 43-85.

Jakucs P. - Keresztesi Z. - Marosi S. - Pécsi M. - Somogyi S. (1989): Tájtípusok - In: Pécsi M. (szerk.): Magyarország Nemzeti Atlasza. MTA Földrajztudományi Kutató Intézete, Budapest, pp. 90-91.

Ji, L. - Peters, A. J. (2006): Performance evaluation of spectral vegetation indices using a statistical sensitivity function. Remote Sensing of Environment, 106, pp. 59-65.

Jiang, Z. - Huete, A.R. - Didan, K. - Miura, T. (2008): Development of a two-band enhanced vegetation index without a blue band. Remote Sensing of Environment, 112 (10) pp. 3833-3845.

Jordan, C. F. (1969): Derivation of leaf-area index from quality of light on the forest floor. Ecology, 50, pp. 440-551. 
Jung A. (2005): Spektrális információk alkalmazása a városklíma-kutatásban. Doktori értekezés. Kertészettudományi Doktori Iskola, Budapest. 131 p.

Kákonyi Á. (2009): A csatorna ügye: víziók és valóság. Előadásanyag. Kiskunsági Nemzeti Park Természet háza, 2009. 12.01. www.alfoldinfo.hu/homokhatsag/dunatiszacsatorna/kakonyi.ppt

Kardeván P. - Reisinger P. - Tamás J. - Jung A. (2005): A parlagfü detektálás távérzékelési módszereinek vizsgálata: 1. rész a távérzékelési képek osztályozási hatékonyságának növelése a parlagfü (Ambrosia artemisiifolia L.) reprezentatív spektrumainak terepi DGPS mérésekkel történő kiválasztásával. Magyar Gyomkutatás és Technológia 2, pp. 53-67.

Kaufman, Y.J. - Tanré, D. (1992): Atmospherically resistant vegetation index (ARVI) for EOS-MODIS. IEEE Transactions on Geoscience and Remote Sensing, 30, pp. 261-270.

Kaurivi, J.Z.U. - Huete, A.R. - Didan, K. (2003): Multitemporal MODIS-EVI relationships with precipitation and temperature at the Santa Rita Experimental Range, USDA Forest Service Proceedings, RMRS-P-30, 112-124.

Kauth, R.J. - Thomas, G.S. (1976). The tasseled cap - a graphic description of the spectral temporal development of agricultural crops as seen by Landsat. (Czimber K. 2001. Geoinformatika - elektronikus jegyzet hivatkozása alapján).

Kennedy, R. E. - Townsend, P. A. - Gross, J.E. - Cohen, W. B. - Bolstad, P. et al. (2009): Remote $\mathrm{s}$ ensing change detection tools for natural resource managers: understanding concepts and tradeoffs int he design of landscape monitoring projects. Remote Sensing of Environment, 113, pp. 1382-1396.

Kerék B. (2003): A talaj-alapkőzet-talajvíz rendszer agrogeológiai és környezetföldtani vizsgálata a bugaci mintaterületen. PhD értekezés. Debreceni Egyetem, Természettudományi Kar, Debrecen.

Keresztesi Z. - Marosi S. - Pécsi M. - Somogyi S. (1989): Természeti tájak rendszertani felosztása. 1:100.0000. In: Pécsi M. (szerk.): Magyarország Nemzeti Atlasza. MTA Földrajztudományi Kutató Intézete, Budapest, pp. 86-87.

Kern A. - Barcza Z. - Bartholy J. - Pongrácz R. - Fassang Á. (2007): Vegetációs index adatsorok klimatikus vizsgálata Magyarországra. “Klíma-21” füzetek, 49, pp. 26-37.

Kertész Á. (2001): A globális klímaváltozás természetföldrajza. Holnap Kiadó, Bp. 144p

Kertész Á. - Papp S. - Sántha A. (2001): Az aridifikáció folyamatai a Duna-Tisza közén. Földrajzi Értesítő, 50 (1-4.), pp. 115-126. 
Kiss A. (2004): Hogyan tovább tanyavilág? In: Csatári B. - Kiss A. (szerk.): Tanyai kaleidoszkóp. MTA RKK ATI, Kecskemét. pp. 39-63.

Kiss-Pető T. (2005): A politikai határok természetrajza és a hozzájuk való alkalmazkodás lehetséges módjai a Felső-Bácskában. Átalakulási folyamatok Közép-Európában konferencia adatbázisa. Cd kiadvány. Online at:

http://www.sze.hu/etk/_konferencia/publikacio/Net/eloadas_kiss_peto_tibor.doc

Kiss T. - Tornyánszki É. (2006): Futóhomok területek geomorfológiai vizsgálata a Duna-Tisza közén. III. Magyar Földrajzi Konferencia Tudományos Közleményei, CDkiadvány, MTA FKI, ISBN 963-9545-12-0

Konecsny K. (2007): A Duna-Tisza közi hátság felszíni lefolyása és vízrajzi észlelések EU elvárásoknak megfelelő fejlesztése. Magyar Hidrológiai Társaság XXV. Országos Vándorgyülés http://www.hidrologia.hu/ovgytata/25/2szekcio.html

Konkolyné Gyúró É. (1990): A tájpotenciál és a tájhasználat összefüggései a Zemplénihegységben. Kandidátusi értekezés, Kertészeti és Élelmiszeripari Egyetem, 158 pp.

Konkolyné Gyúró É. (1994): Tájtörténeti feltárás a tájvédelem szolgálatában a tokajhegyaljai borvidék példáján. Észak- és Kelet-Magyarországi Földrajzi Évkönyv, pp. 209-214.

Kovács Gy. (1984): Az ásványi nyersanyagtermelés hatása a felszíni és a felszínalatti vizekre. Időjárás. pp. 5-6.

Kovács A. (2005): A Duna - Tisza közi talajvízszint változásának vizsgálata geoinformatikai eszközökkel. Szakdolgozat. SZTE Természeti Földrajzi és Geoinformatikai Tanszék. 59 p.

Kovács A. D. (szerk.) (2005): Tanyakutatás 2005. MTA RKK Alföldi Tudományos Intézete. http://www.alfoldinfo.hu/tanyakutatas

Kovács F. (2005): The investigation of regional variations in biomass production for the area of the Danube-Tisza Interfluve using satellite image analysis. Acta Universitatis Szegediensis, Acta Geographica, 38, pp. 118-136.

Kovács F. (2006): Tájváltozások értékelése geoinformatikai módszerekkel a Duna-Tisza közén különös tekintettel a szárazodás problémájára. Doktori értekezés. 105 p.

Kovács F. (2009a): Változékonyság értékelése vizes élőhelyeken müholdképek alapján. Hidrológiai Közlöny, 89 (2), pp. 57-61.

Kovács F. (2009b): Területhasználati változások a településegyüttes térségében - távérzékelési módszerek interpretációja. In.: Rich J. - Salamin G. - Sütő A. - Hoffmann Cs. - Gere L.: Koordinálatlan városnövekedés az együtt tervezhető térségekben: A települések lehetséges tervezési válasza. Kutatási jelentés. VÁTI, Budapest. pp. 58-78. 
Kovács, F. - Rakonczai, J. - Kiss, T. (2004): Possibilities of remote sensing in the investigation of aridification processes - Case study on the Great Hungarian Plain, Hungary. In: Goossens, R. (ed.) Remote Sensing in Transition, Proceedings of the 23rd EARSeL Symposium, Millpress. pp.409-415.

Kovács F. - Rakonczai J. (2005): A szárazodás és környezeti hatásai az Alföldön. In.: Előadások gyüjteménye, 8. Müszaki Térinformatikai Konferencia. Müszaki Térinformatikai Egyesület, Szeged. pp. 115-121. http://www.gita.hu/e2005/b4_3.pdf

Kristóf D. (2005): Távérzékelési módszereke a környezetgazdálkodásban. Doktori (PhD) értekezés. SZIE. 146 p.

Kun A. (1998): Száraz gyepek Magyarországon. In: Kiszel V. (szerk.): Természetvédelem területhasználók számára. Göncöl Alapítvány, Vác.

Kuti L. - Vatai J. (1996): A talajvíz szintje a felszín alatt. 1996. augusztus-szeptember. Magyar Állami Földtani Intézet.

Kuti L. - Vatai J. - Müller T. - Kerék B. (2002): A talajvíztükör mélységeinek változása a Duna-Tisza közi hátságon. Földtani Közlöny, 132, pp. 317-325.

Lacava, T. - Greco, M. - Di Leo E.V. - Martino, G. - Pergola, N. - Romano, F. Sannazzaro, F. - Tramutoli, V. 2005: Assessing the potential of SWVI (SoilWetness Variation Index) for hydrological risk monitoring by means of satellite microwave observations Advances in Geosciences, 2, pp.221-227.

Láng I. - Csete L. - Jolánkai M. (szerk.) (2007): A globális klímaváltozás-hazai hatások és válaszok-A VAHAVA jelentés. Szaktudás Kiadó, Budapest. 220 p.

Liebe P. (1994): A rétegvízkészletek és a nyomásszintek változása a Duna-Tisza közi hátságon és azok kihatásai a talajvízszintekre. In: Pálfai I. (szerk.): A Nagyalföld Alapítvány Kötetei 3. A Duna-Tisza közi hátság vízgazdálkodási problémái. pp. 25-30.

Liebe P. (2000): Az Alföld felszín alatti vízkészlete. In: Pálfai I. (szerk.): A Nagyalföld Alapítvány kötetei 6. A víz szerepe és jelentősége az Alföldön. pp. 105-117.

Liu, H. Q. - Huete A.R (1995): A feedback based modification of NDVI to minimize canopy background and atmospheric noise. IEEE Transactions on Geoscience and Remote Sensing, 33, pp. 457-465.

Lóczy D. (2010): Tájdinamikai módszertani fejlemények. In: Szilassi P. - Henits L. (szerk.): Tájváltozás értékelési módszerei a XXI. Században. Tudományos konferencia és mühelymunka tanulmányai, Szeged. pp. 9-23. 
Lukács A. - Szigetvári Cs. - Botos I. - Rév Sz. (2004): Tájtörténeti vizsgálatok és a tájrehabilitációlehetőségei a Nyírségben. Ifjú Botanikusok Baráti Köre és az Emisszió Természet és Környezetvédelmi Egyesület, Nyíregyháza, 24 p.

Major G. - Major P. - Vargay Z. (1991): A Duna-Tisza közi hátság lefolyási viszonyainak hatása a talajvízszint változására. Vízügyi Közlemények, 73 (2), pp. 143-152.

Major P. - Neppel F. (1988): A Duna-Tisza közi talajvízszint süllyedések. Vízügyi Közlemények, 70 (4), pp. 605-626.

Major P. - Neppel F. (1990): Válasz Szofridt István hozzászólására. Vízügyi Közlemények, 72 (4), pp. 402-406.

Margóczi K. - Rakonczai J. - Barna Gy. - Majláth I. (2008): Szikes növénytársulások összetételének és talajának hosszú távú változása a Szabadkígyósi pusztán. In: Kalivoda B. (szerk.) Crisicum 5. Körös-Maros Nemzeti Park Igazgatóság. pp. 71-84.

Marosi S. (1980): Tájkutatási irányzatok, tájértékelés, tájtipológiai eredmények különböző nagyságú és adottságú hazai típusterületeken. Akadémiai doktori értekezés. Bp. 162 p.

Marosi S. - Somogyi S. (szerk.) (1990a): Magyarország kistájainak katasztere. MTA Földrajztudományi Kutató Intézet, Budapest. 479 p.

Marosi S. - Somogyi S. (szerk.) (1990b): Magyarország kistájainak kataszterének térképmelléklete. MTA Földrajztudományi Kutató Intézet, Budapest.

Martinovich, L. - Winkler, P. - Iván, Gy. - Doroszlai, T. - Kiss, M. (2003): GIS support for the vineyard register of the Hungarian Ministry of Agriculture and Rural Development. In Proc. EFITA Conference, Debrecen, Proceedings Vol. 1 pp. 401-407.

Márkus, I. - Király, G. - Czimber, K. - Szentesi, L. (2000): Research of the Application of Remote Sensing and GIS in Forestry. In III. International Symposium: Application of Remote Sensing in Forestry. Proceedings, Zvolen, pp. 41-48.

Matsushita, B. - Yang, W. - Chen, J. - Onda, Y. - Qiu, G. (2007): Sensitivity of the Enhanced Vegetation Index (EVI) and Normalized Difference Vegetation Index (NDVI) to Topographic Effects: A Case Study in High-Density Cypress Forest. Sensors, 7, pp. 2636-2651.

Mezősi G. (1989): A kistájak természeti adottságainak értékelése a szántóföldi növénytermelés szempontjából. In: Pécsi M. (szerk.): Magyarország Nemzeti Atlasza. MTA Földrajztudományi Kutató Intézete, Budapest, pp. 92/A.

Mezősi G. - Bata T. (2010): A földrajzi tájak határai. Földrajzi közlemények (megjelenés alatt). 
Mezősi G. - Fejes Cs. (2004): A tájak ökológiai foltjainak kvantitatív elemzése. In Barton G. - Dormány G. - Rakonczai J. (szerk.): A magyar földrajz kurrens eredményei. A II. Magyar Földrajzi Konferencia CD kötete. pp. 1166-1177.

Miháltz I. (1950): A Duna-Tisza köze déli részének földtani felvétele. Magyar Állami Földtani Intézet Évi Jelentése 1950-ről. Budapest. pp. 113-144.

Miháltz I. (1953): Az Alföld negyedkori üledékeinek tagolódása. In: Alföldi Kongresszus, MTA OK. 9. pp. 102-107.

Mika J. - Ambrózy P. - Bartholy J. - Nemes Cs. - Pálvölgyi T. (1995): Az Alföld éghajlatának időbeli változékonysága és változási tendenciái a hazai szakirodalom tükrében. Vízügyi Közlemények, 78, pp. 261-283.

Molnár B. (1965): Pliocén és pleisztocén lehordási területváltozások az Alföldön. Földtani Közlöny, 96, pp. 403-413.

Molnár B. (1977): A Duna-Tisza köz felsőpliocén (levantei) és pleisztocén földtani fejlödéstörténete. Földtani Közlöny, 107, pp. 1-16.

Molnár B. (1980): Hiperszalin tavi dolomitképződés a Duna-Tisza közén. Földtani Közlöny, 110, pp. 45-64.

Molnár B. - Balázs R. (2009): A Duna-Tisza köze földtani fejlődéstörténete és földtani értékei. Kiskunsági Nemzeti Park. (Megtekintve: 2010. 04. 24.) http://knp.nemzetipark.gov.hu/index.php?.pg=menu_2108

Molnár Zs. (2003a): Tájtörténeti adatok a hazai szikesek növényzetének ismeretéhez. In: Tóth A. (szerk.): Ohattól Farkas-szigetig. Ökológiai kultúra-ökológiai nevelés. Alföldkutatásért Alapítvány, Budapest, Kisújszállás, pp. 71-95.

Molnár Zs. (szerk.) (2003b): A Kiskunság száraz homoki növényzete. TermészetBÚVÁR Alapítvány Kiadó, Kecskemét. 159 p.

Molnár Zs. - Bíró M. (2010): A néhány száz évre visszatekintő, botanikai célú történeti tájökológiai kutatások módszertana. In: Szilassi P. - Henits L. (szerk): Tájváltozás értékelési módszerei a XXI. Században. Tudományos konferencia és mühelymunka tanulmányai, Szeged. pp. 109-126.

Molnár, Zs. - Bartha, S. - Seregélyes, T. - Illyés, E. - Botta-Dukát Z., et al. (2007): A Grid Based, Satellite-Image Supported, Multi-Attributed Vegetation Mapping Method (MÉTA). Folia Geobotanica, 42, pp. 225-247.

Molnár Cs. - Molnár Zs. - Barina Z. - Bauer N. - Biró M. et al. (2008): Vegetationbased landscape-regions of Hungary. Acta Botanica Hungarica, 50, pp. 47-58. 
Mucsi L. - Kovács F. (2005): A homokhátsági tanyás térségek tájhasználat változásai. In: Csatári B. - Kovács A. D. (szerk), Tanyakutatás 2005 pp. 61-96. MTA RKK Alföldi Tudományos Intézete, Kecskemét.

Mucsi L. - Kovács F. - Henits L. - Tobak Z. - B. van Leeuwen - Szatmári J. - Mészáros M. (2007): Városi területhasználat és felszínborítás vizsgálata távérzékeléses módszerekkel. In. Mezősi G. (szerk.) Városökológia. Földrajzi Tanulmányok, Vol.1. JatePress, Szeged. pp. 19-42.

Nagy A. - Tamás J. (2008): Nehézfémmel szennyezett területek értékelése távérzékelt adatok alapján. In: Simon L. (szerk) Talajvédelem, pp. 291-300.

Nebojszki L. (2004): Illancsi pillantások. Természet világa, 135 (10), pp. 454-457.

NÉS (2007): Nemzeti Éghajlatváltozási Stratégia. Környezetvédelmi és Vízügyi Minisztérium. Budapest. http://klima.kvvm.hu/documents/14/nes_080219.pdf

Orlóci I. (2003): A Tiszát a Dunával összekötő csatorna: a Duna-Tisza csatorna. Hidrológiai Közlöny, 83 (4), pp. 243-250.

Qi, J. - Chehbouni, A. - Huete, A.R. - Kerr, Y.H. - Sorooshian, S. (1994): A modified soil-adjusted vegetation index. Remote Sensing of Environment, 48, pp. 119-126.

Pálfai I. (szerk) (1990): Alapozó szakvélemények a Duna-Tisza közi vízrendezések hatásvizsgálatához, VITUKI, Budapest.

Pálfai I. (1992): Vízhiány a Duna-Tisza hátságon. Hidrológiai Tájékoztató, 32 (1), pp. 43-44.

Pálfai I. (szerk) (1993): Változások a Duna-Tisza köze vízháztartásában. Országos Vízügyi Föigazgatóság, Budapest.

Pálfai I. (szerk.) (1994a): A Duna-Tisza közi hátság vízgazdálkodási problémái. In: Pálfai I. (szerk.) A Nagyalföld Alapítvány kötetei 3. A Duna-Tisza közi hátság vízgazdálkodási problémái. Békéscsaba. 126 p.

Pálfai I. (1994b): Összefoglaló tanulmány a Duna-Tisza közi talajvízszint-süllyedés okairól és a vízhiányos helyzet javításának lehetőségeiről. In: Pálfai I. (szerk.): A Nagyalföld Alapítvány kötetei 3. A Duna-Tisza közi hátság vízgazdálkodási problémái. pp. 111-126.

Pálfay I. (1995): A Duna-Tisza közi hátság vízgazdálkodási problémái és megoldásuk lehetséges útjai. Vízügyi Közlemények, 77 (2). pp. 144-165.

Pálfai I. (szerk) (1997): A Duna-Tisza csatorna tervezett változatainak vízügyi szempontú értékelése. VÁTI Rt. Területfejlesztési Iroda. Budapest.

Pálfai I. - Szilárd Gy. - Váradi J. (1998): Az aszály vízgazdálkodási hatásai Magyarországon. Vízügyi Közlemények, 80 (1), pp. 169-179. 
Pálfai I. (szerk) (2000a): A víz szerepe és jelentősége az Alföldön. A Nagyalföld Alapítvány kötetei 6. Nagyalföld Alapítvány. Békéscsaba 219 p.

Pálfai I. (2000b): Az Alföld belvízi veszélyeztetettsége és aszályérzékenysége. In: Pálfai I. (szerk): A Nagyalföld Alapítvány kötetei 6. A víz szerepe és jelentősége az Alföldön. pp. 85-96.

Pálfai I. (2003): A vízháztartás helyzete és a vízgazdálkodás fejlesztési lehetőségei a Duna-Tisza közi Homokhátságon. Hidrológiai Közlöny, 83 (4), pp. 251-253.

Pálfai I. (szerk.) (2005): Elemző tanulmány a Duna-Tisza közi Homohátság vízháztartási helyzetéről és vízpótlásának szükségességéről. Bács-Kiskun megyei önkormányzat. 97 p.

Pándi I. (2006): Dél-kiskunsági homokbuckások vegetációja és tájhasználat-története. I. Magyar Tájökológiai Konferencia. 2006. IV. 7-9. Debrecen.

Pándi I. (2008): Illancs. In: Király G. - Molnár Zs. - Bölöni J. - Csiky J. - Vojtkó A. (szerk.): Magyarország földrajzi kistájainak növényzete. MTA ÖKBI. Vácrátót, p. 23.

Pécsi M. (1957): Kalocsa és Kecel-Kiskőrös környékének geomorfológiai kérdései. Földrajzi Értesítö, 6, pp. 421-442.

Pécsi M. (1959): A Magyarországi Duna-völgy kialakulása és felszínalaktana. In: Bulla B. (szerk.) Földrajzi monográfiák III. Akadémiai Kiadó. Budapest.

Pécsi M. (1972): A környezet komplex kutatásának fölrajzi problémái. Földrajzi Közlemények, 20, pp. 127-132.

Pécsi M. - Somogyi S. (1967): Magyarország természeti tájai és geomorfológiai körzetei. Földrajzi Közlemények, 15, pp. 285-304.

Pécsi M. - Somogyi S. - Jakucs P. (1972): Magyarország tájtípusai. Földrajzi Értesítő, 21 (1), pp. 5-12.

Rakonczai J. (2006): Klímaváltozás - Aridifikáció - Változó Tájak In.: Kiss A. - Mezősi G. -Sümeghy Z. (szerk.): Táj, környezet és társadalom. Ünnepi Tanulmányok Keveiné Bárány Ilona professzor asszony tiszteletére, pp. 593-603.

Rakonczai J. (2008a): Globális környezeti kihívásaink. Universitas Szeged Kiadó. 204 p.

Rakonczai J. (2008b): The effect of global changes to the alteration of soils and the landscape in the Great Hungarian Plain. In: Eurosoil 2008. Book of abstracts, P582. Wien.

Rakonczai J. - Bódis K. (2001): A geoinformatika alkalmazása a környezeti változások kvantitatív értékelésében. A földrajz eredményei az új évezred küszöbén. A Magyar Földrajzi Konferencia anyaga CD-n 19 old. Szeged http://geography.hu/mfk2001/cikkek/RakonczaiBodis.pdf 
Rakonczai J. - Bódis K. (2002): A környezeti változások következményei az Alföld felszín alatti vízkészleteiben. In: Mészáros R. - Schweitzer F. - Tóth J. (szerk.) Jakucs László, a tudós, az ismeretterjesztő és a művész. MTA Földrajztudományi Kutatóintézet - SZTE Gazdaság- és Társadalomföldrajzi Tanszék. pp. 227-232.

Rakonczai, J. - Bozsó, G. - Margóczi, K. - Barna, Gy. - Pál-Molnár, E. (2008): Modification of salt-affected soils and their vegetation under the influence of climate change at the steppe of Szabadkígyós (Hungary). Cereal Research Communications, 36, pp. 2047-2050.

Rakonczai J. - Kovács F. (2004): A szárazódási folyamat területi és időbeli változásainak vizsgálata az Alföldön. A VAHAVA program számára készített értékelés. Kézirat. 34 p.

Rakonczai J. - Kovács F. (2005): Globális változások és hazai tájváltozások. In: Galbács, Z. (ed.): The 12th Symposium on Analytical and Environmental Problems, pp. 286-290.

Rónay I. (szerk) (1998): Vízgazdálkodási fejlesztési tervek és megvalósulásuk a DunaTisza közén. Országos Vízügyi Főigazgatóság. Budapest.

Rónai A. (1961): Az Alföld talajvíztérképe. Magyarázó a talajvíztuikör felszínalatti mélységének 1:200.000-es méretarányú térképéhez. Magyar Állami Földtani Intézet, Bp, 120 p.

Rónai A. (1983): A vízszintingadozások többéves irányvonala az alföldi artézi víztartó rétegekben. Hidrológiai Közlöny, 63 (7), pp. 289-300.

Rónai A. (1985): Az Alföld negyedidőszaki földtana. Geologica Hungarica, Series Geologica, 21, 466 p.

Rónay I. - Keve G. (2009): Mintaprojekt a Duna-Tisza közi Közép-homokhátság helyzetének javítására. Magyar Hidrológiai Társaság XXVII. Országos Vándorgyülése, Baja. http://www.hidrologia.hu/vandorgyules/27/dolgozatok/2szekcio.html

Rondeaux, G. - Steven, M. - Baret, F. (1996): Optimization of soil-adjusted vegetation indices. Remote Sensing of Environment, 55, pp. 95-107.

Rouse, Jr., J.W - Haas, R. H. - Shell, J.A. - Deering, D.W (1974): Monitoring vegetation systems in the Great Plains with ERTS. Third earth resources technology staellite-1 symphosium, Vol.1. pp. 309-317.

Schrett A. (2005): Vízhiány okozta élőhelyváltozások a Kiskunsági-homokháton. ÖKO, 13 (1-2), pp. 100-119.

Somay L. - Batáry P. - Boros E. (2009): A tájhasználat hatása homoki gyepek madárközösségeire. Természetvédelmi Közlemények, 15, pp. 204-215.

Somogyi S. (1967): Az Alföld tájtérképelése. In: Marosi S.- Szilárd J. (szerk.): A dunai Alföld. Budapest. Akadémiai Kiadó. pp. 91-163. 
Szabó Sz. - Csorba P. (2009): Tájmetriai mutatók kiválasztásának lehetséges módszertana egy esettenulmány példáján, Tájökológiai Lapok 7 (1), pp. 141-153.

Szalai J. (2010): Talajvízszint-változások az Alföldön. In: Rakonczai J. (szerk.): Környezeti változások és az Alföld. A Nagyalföld Alapítvány Kötetei 7. (megjelenés alatt)

Szalai J. - Nagy Gy. (2006): Az utóbbi évtized időjárási eseményeinek hatása a talajvízszintek alakulására a Duna-Tisza közén. Magyar Hidrológiai Társaság XXVI. Hidrológiai Vándorgyülése. Pécs.

http://www.hidrologia.hu/vandorgyules/24/5szekcio/240506.htm

Szalai J. - Varga Gy. - Pappné Urbán J. (2007): A hidrometeorológiai és talajvízszintváltozások értékelése a Duna-Tisza közén az EU VKI szempontjainak tükrében. Magyar Hidrológiai Társaság XXV. Országos Vándorgyülés.

http://www.hidrologia.hu/ovgytata/25/2szekcio.html

Szalai S. - Szentimrey T. (2001): Melegedett-e Magyarország éghajlata a XX. században? In: Szász G. (szerk): Berényi Dénes születésének centenáris jubílieumi tudományos ülése. DE-MTA-OMSZ, 15 p.

Szanyi, J. - Kovács, B. (2009): Egyesített 3D hidrodinamikai modell a felszín alatti vizek használatának fenntartható fejlesztéséhez a magyar-szerb országhatár menti régióban. INTERREG III/A HUSER0602/131.

Szász G. (1997): Az éghajlatváltozás és a fenntartható gazdaság kapcsolata a Nagyalföldön. Alföldi tanulmányok, 16, pp. 35-51.

Szatmári J. (2006): Geoinformatikai módszerek és folyamatmodellek alkalmazása a széleróziós vizsgálatokban. Doktori (Ph.D.) értekezés. SZTE Természeti Földrajzi és Geoinformatikai Tszk. 112 p.

Székely A. (1973): Die Entwicklung der Landschaften. Annales Un. Sci. Bud. Sectio Geographica Tom. VIII. Budapest pp. 163-168.

Szendrei G. (1977): Kiskunsági talajok kalcit és dolomit eloszlásának vizsgálata. Agrokémia és Talajtan, 26, pp. 1-18.

Szilágyi J. - Vörösmarty, Ch. (1993): A Duna-Tisza közi talajvízszint-süllyedések okainak vizsgálata. Vizügyi Közlemények, 75 (3), pp. 280-294.

Szilassi P. (2006): A területhasználat változásának tendenciái a Balaton vízgyüjtőjén a településsoros statisztikai adatok tükrében. In: Kiss A. - Mezősi G. - Sümeghy Z. (szerk.) Táj, környezet és társadalom. Ünnepi Tanulmányok Keveiné Bárány Ilona professzor asszony tiszteletére. Szeged. pp. 667-676 
Szilassi P. (2010): Térképi adatbázisok összehasonlításának javítása tájmetriai elemzések révén. In: Szilassi P. - Henits L. (szerk.): Tájváltozás értékelési módszerei a XXI. Században: Tudományos konferencia és mühelymunka tanulmányai. Szeged. pp. 25-31.

Szofridt I. (1990): Hozzászólás Major Pál és Neppel Ferenc: A Duna-Tisza közi talajvízszint süllyedése címü cikkéhez. Vízügyi Közlemények, 72(3), pp. 287-291.

Szofridt I. (1991): A talajvízsüllyedés és az erdők kapcsolata a Duna-Tisza közi homokon. Erdészeti lapok, 126 (1). pp. 22-23.

Szodfridt I. (1994): Az erdők és a talajvíz kapcsolata a Duna-Tisza közi homokhátságon. A Nagyalföld. Alapítvány kötetei 3. Békéscsaba, pp. 59-67.

Tamás J. (2009): Térinformatika oktatása. In.: FÉNY-TÉR-KÉP 2009 konferencia előadásanyagai. www.geoiq.hu.

TIR (2010): Természetvédelmi Információs Rendszer, Közönségszolgálati Modul. http://geo.kvvm.hu/tir/viewer.htm (Megtekintve: 2009. 09.25.)

Tóth Z. (2004): A Kerca-patak melléki rétek jelene és múltja (esettanulmány a természetvédelmi célú kezelések megalapozásához). Tájökológiai. Lapok, 2 (2), pp. 313-339.

Tóth, T. - Csillag, F. - Biehl, L.L. - Micheli, E. (1991): Characterisation of semivegetated salt-affected soils by means of field remote sensing. Remote Sensing of Environment, 37, pp. 167-80.

Török I. Gy. (1994): Hogyan küzd a magyarországi Duna-Tisza közi régió a 15 éve pusztító aszállyal? Víztükör, 34 (1). pp. 4-5.

Török K. - Kröel-Dulay Gy. - Rédei T. (2006). Tájhasználat, biodiverzitás és ökoszisztéma szolgáltatások kapcsolatának feltárása a Duna-Tisza közi Homokhátságon. In: Szentesi Á. - Szövényi G. - Török J. (szerk.), 7. Magyar Ökológus Kongresszus, p. 212. Bp.

Tress, B. - Tress, G. - Fry, G. (2005): Integrative studies on rural landscapes: Policy expectations and research practise. Landscape and Urban Planning, 70, pp. 177-191.

Túri - Szabó (2009): Néhány tájmetriai mutató és a felbontás kapcsolatának vizsgálata egy tiszazugi tájrészleten. In: Kiss T. (szerk): Természetföldrajzi folyamatok és formák. Geográfus Doktoranduszok IX. Országos Konferenciájának Természetföldrajzos Tanulmányai. pp. 83-92.

Turner, B. L. - Meyer, W. B. (1994): Global Land Use and Land-Cover Change: An Overview. In Meyer, W. - Turner, B.L. (eds): Changes In Land Use and Land Cover: A Global Perspective. University Press, Cambridge. pp. 3-10.

Ünsalan, C. - Boyer, K.L. (2004): Linearized vegetation indices based on a formal statistical framework. IEEE Transactions on Geoscience and Remote Sensing, 42, pp. 1575-1585. 
UNCCD (2006): Second National Report of the Republic of Hungary on the implementation of the United Nations Convention to Combat Desertification. Ministry of Environment and Water of the Republic of Hungary. 24 p.

Várallyay Gy. (1984): Magyarországi homoktalajok vízgazdálkodási problémái. Agrokémia és Talajtan, 33, pp. 159-169.

Várallyay Gy. (1988): Talaj, mint a biomassza-termelés aszályérzékenységének tényezője, Vizügyi közlemények, 70, pp. 46-68.

Várallyay Gy. - Szücs L. - Rajkai K. - Zilahy P. - Murányi A. (1980): Magyarországi talajok vízgazdálkodási tulajdonságainak kategóriarendszere és 1:100 000 méretarányú térképe. Agrokémia és Talajtan, 29, pp. 77-112.

Varga Á. (2009): Vizes élőhelyek a Duna-Tisza köze déli részén, egy kiskunhalasi mintaterület példáján. In: Kiss T. (szerk): Természetföldrajzi folyamatok és formák. Geográfus Doktoranduszok IX. Országos Konferenciájának Természetföldrajzos Tanulmányai, Szeged, pp. 99-111.

VÁTI (1994a): Tézisek és megállapítások a homokhátság talajvízszint süllyedésének terület-, illetve településfejlesztési kölcsönhatásairól. VÁTI Rt. Magyar Regionális Fejlesztési Urbanisztikai és Építészeti Részvénytársaság (Felelős tervező: Zala Gy.). Bp.

VÁTI (1994b): Kistérségek vízpótlásának megoldása, lokális vízpótlási rendszerek kistérségi fejlesztési feladatainak meghatározása. VÁTI Rt. Magyar Regionális Fejlesztési Urbanisztikai és Építészeti Részvénytársaság (Felelős tervező: Zala Gy.). Budapest.

Veldkamp, A. - Fresco, L. O. (1996): CLUE-CR: an integrated multiscale model to stimulate land use change scenarios in Costa Rica. Ecological Modelling, 91, pp. 231-248.

Verburg, P. H. - Veldkamp, A. - De Koning, G.H.J. - Kok, K. - Bouma, J. (1999): A spatial explicit allocation procedure for modelling the pattern of land use change based upon actual land use. Ecological Modelling, 116, pp. 45-61.

VITUKI (1989): A Duna-Tisza közi talajvízszint-süllyedés és a rétegvíztermelés kapcsolatának modellezése. Témabeszámoló. Vízgazdálkodási Tudományos Kutatóközpont. (Témafelelös: Davideszné Dömötör K.), Budapest.

VITUKI (1991): A vízjogi engedélyek nélküli talajvízkivételek becslése. Vízgazdákodási Tudományos Kutatóközpont (Témaf: Simonffy Z. ), Budapest.

VITUKI (2005): A Duna-Tisza köze hidrológiai - környezeti állapotértékelése (Varga György főszerk.) VITUKI KHT, Budapest.

Víz Keretirányelv (2009): Víz Keretirányelv 2. melléklet Intézkedési Csomagok http://www.vizeink.hu/files/vizeink.hu_0067.pdf 
Völgyesi I. (2002): Vízgazdálkodási beavatkozások lehetőségei a talajvízszint-süllyedések megakadályozása érdekében a Duna-Tisza közén. VÖLGYESI Mérnökiroda Hidrogeológiai szolgáltató kft.

Völgyesi I. (2006): A Homokhátság felszín alatti vízháztartása - vízpótlási és vízvisszatartási lehetőségek. MHT XXIV. Országos Vándgyülés Kiadványa. Pécs, 2006. Online at: http://volgyesi.uw.hu/dokuk/homokhatsag.pdf

Wallace, C.S.A. - Thomas, K.A. (2008): An Annual Plant Growth Proxy in the Mojave Desert Using MODIS-EVI Data. Sensors, 8, pp. 7792-7808.

Waring, R.H. - Milner, K.S. - Jolly, W.M. - Phillips, L. - McWethy, D. (2006):Assessment of site index and forest growth capacity across the Pacific and Inland Northwest U.S.A. with a MODIS satellite-derived vegetation index. Forest Ecology and Management, 228, pp. 285-291

Zhanga, X. - Friedla, M.A - Schaaf, C.B. - Strahlera, A.H. - Hodges, J.C. - Gao, F.Reed, B.C. - Huete, A. (2003): Monitoring vegetation phenology using MODIS. Remote Sensing of Environment, 84, pp. 471-475.

Zsákovics G. - Kovács F. - Kiss A. (2009): A szárazodás veszélyének többszempontú térbeli elemzése a Duna-Tisza közén. Tájökológiai Lapok, 7 (1), pp. 117-126.

\section{Jogszabályok, rendeletek, határozatok:}

2042/1994. (V.9.) Kormány határozat az Alföld területfejlesztési, tájvédelmi és tájhasznosítási feladatairól.

2087/1995. (IV.3.) Kormány határozat a Duna-Tisza közi hátság kritikus vízháztartási helyzetéről

1995. évi LIII. törvény a környezet védelmének általános szabályairól 1996. évi LIII. törvény a természet védelméről

2286/1996. (X.25) Kormány határozat a Duna-Tisza közi hátság vízpótlásáról 83/1997. (IX. 26.) OGY határozat a Nemzeti Környezetvédelmi Programról

2271/1999. (X.22.) Kormány határozat a Duna-Tisza közi homokhátság vízháztartási helyzetéről és a további szükséges intézkedésekről

132/2003. (XII.11.) OGY határozat a 2003-2008. közötti időszakra szóló Nemzeti Környezetvédelmi Programról

2095/2004.(IV.27.) Kormány határozat a Duna-Tisza közi hátság területén bekövetkezett kedvezőtlen változások hatásainak mérsékléséről

1067/2005. (VI. 30.) Kormány határozat az EU-támogatásra számot tartó, 2007. évi kezdésre ütemezett nagyprojektek előkészítésének költségvetési támogatásáról 


\section{Térképi adatforrások:}

I. katonai felmérés (1780-1784): Coll. XIII Sectio XXX, XXXI, XXXII szelvények, Coll. XIV. Sectio XXX, XXXI, XXXII, XXXIII szelvények, Coll. XV, Sectio XXX, XXXI, XXXII szelvények. Méretarány: 1:28.000.

II. katonai felmérés (1806-1869): XXXII/61, 62 szelvények, XXXIII/60, 61, 62 szelvények, XXXIV/60, 61. szelvények. Méretarány: 1:28.000

III. katonai felmérés (1869-1887): 5362-4, 5463-1, 5463-3,5363-3, 5462-1, 5462-2, 54623, 5462-4, 5463-3, 5562-, 5562-2 szelvények. Méretarány: 1:25.000.

Kreybig-féle Átnézetes Talajismereti Térképsorozat (1949): 5462/4 szelvény. Méretarány: $1: 25.000$.

Topográfiai felmérés (1960): L-34-51-A-d, L-34-51-B-c, L-34-51-B-d, L-34-51-C-b, L-3451-C-d, L-34-51-D-a, L-34-51-D-b, L-34-51-D-c, L-34-51-D-d, L-34-62-B-b, L-3462-B-d, L-34-63-A-a, L-34-63-A-b, L-34-63-A-c, L-34-63-A-d, L-34-63-B-a, L-3463-B-b szelvények. SZTE Természeti Fölrajzi és Geoinformatikai Tanszék. Méretarány: $1: 25.000$.

Topográfiai felmérés (1982): 15-221, 25-123, 25-221, 25-222, 25-223, 25-224, 25-232, 25-233, $25-234,25-241,25-242,25-243,25-244,25-324,25-342,25-344,25-411,25-412,25-$ $413,25-414,25-421,25-422,25-423,25-424,25-431,25-432,25-433,25-434,25-441$, 25-442, 25-443, 25-444, 26-113, 26-131, 26-133, 26-311, 26-313, 35-441, 35-443, 35-444 szelvények. SZTE Természeti Fölrajzi és Geoinformatikai Tanszék. Méretarány: 1:10.000.

Földtani térképek (1982-1991): L-34-63 Jánoshalma (Bácsalmás), L-34-62 Baja, L-34-51 Kiskunhalas. Az Alföld Földtani Atlasza. Magyar Állami Földtani Intézet, Budapest. Méretarány: 1:100.000.

Ortofotó (2005): r_126, r_128, r_129, r_131, r_140, r_146, r_148, r_149, r_150, r_151, r_152, r_153, r_155, r_157, r_158, r_159, r_160, r_161 szelvények. Méretarány: $1: 10.000$.

\section{Adatbázisok:}

Agrotopográfiai adatbázis. MTA Talajtani Kutató Intézet, Budapest.

Aster Global Digital Elevation Model (ASTGTM_N46E019).

http://www.ersdac.or.jp/GDEM/E/index.html

Magyarország 1:50.000-es felszínborítás térképezése (a CLC50 adatbázis, 1998-1999).

Földmérési és Távérzékelési Intézet, Budapest.

Magyarország vegetációs szempontú tájbeosztásának (MOLNÁR et al. 2008) térinformatikai alapállománya. 


\title{
MELLÉKLETEK
}

\author{
1. melléklet
}

További keresztszelvények az. Illancson (szerkesztette: Kuti L., Ladányi Zs.)

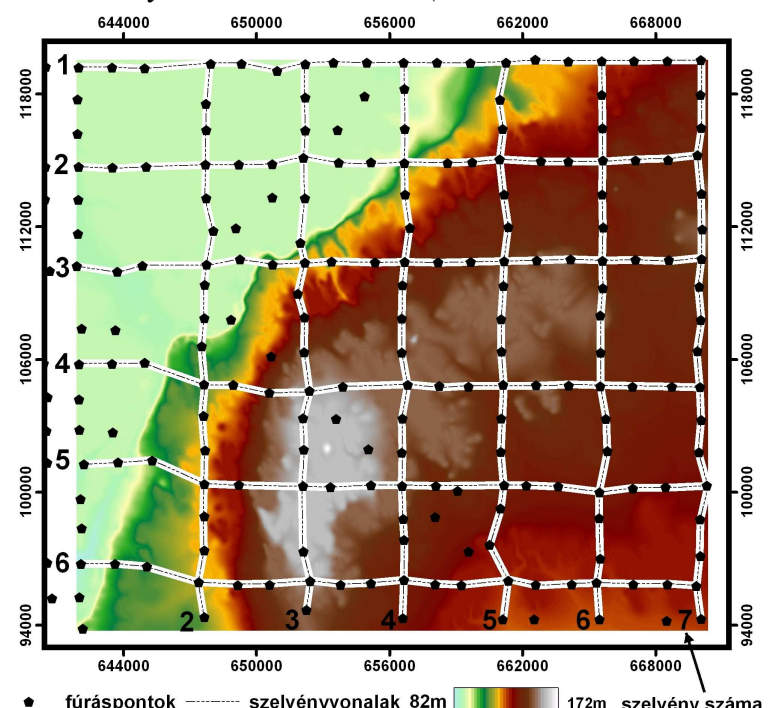

ÉD-2

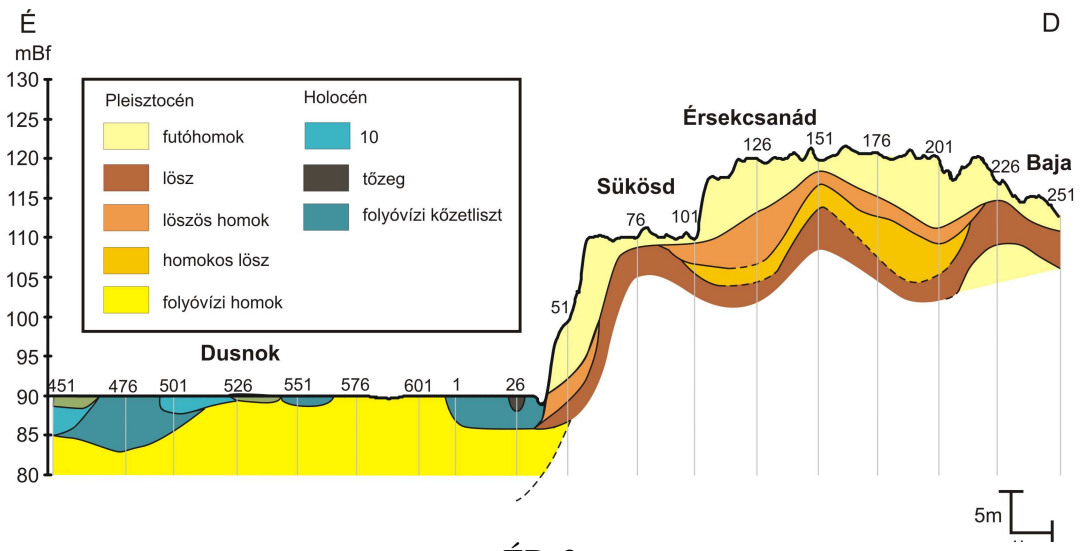

ÉD-3

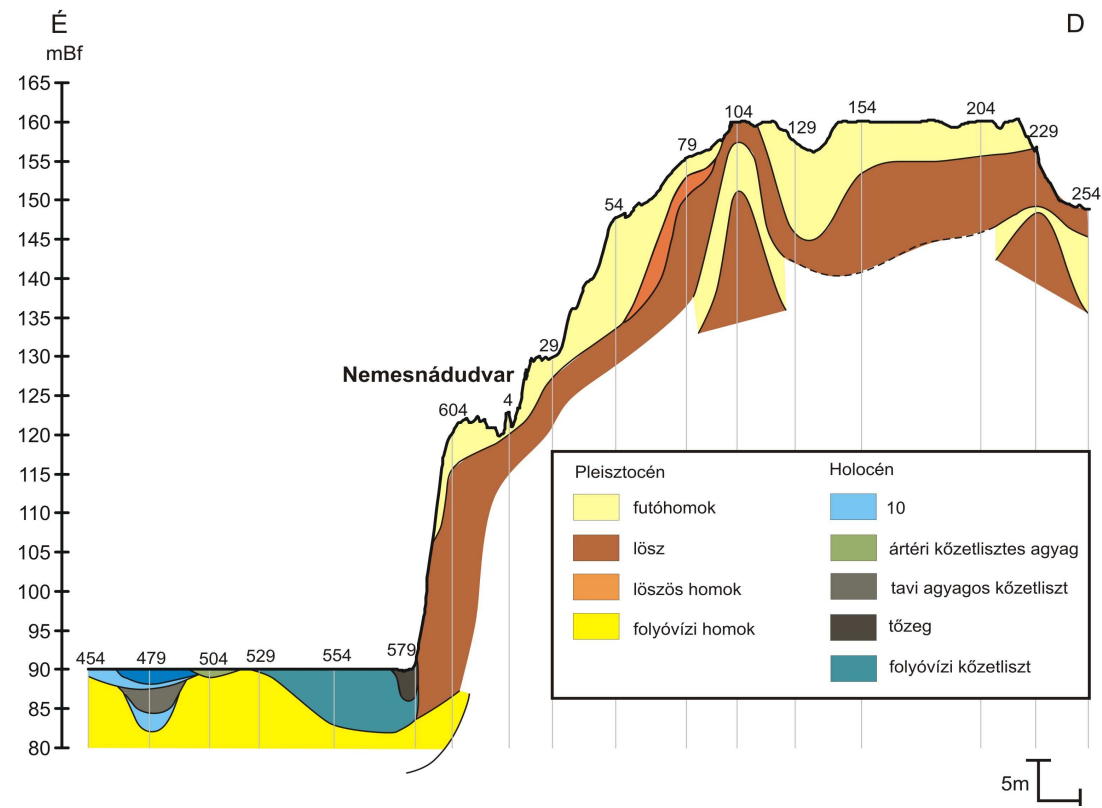


ÉD-4

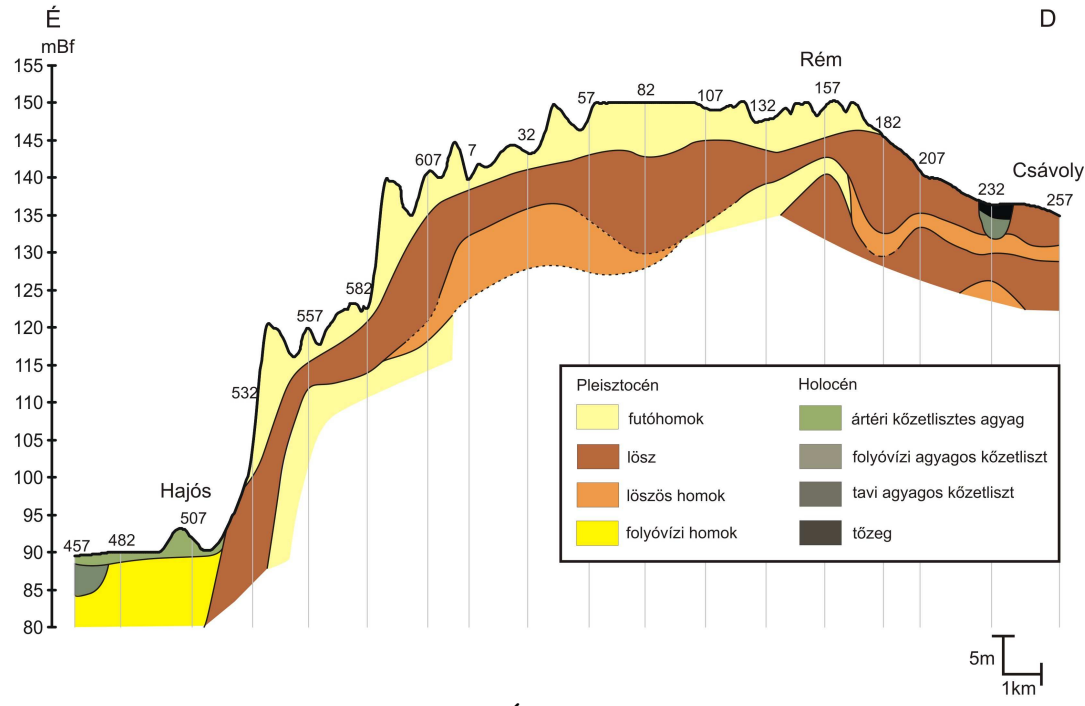

ÉD-6

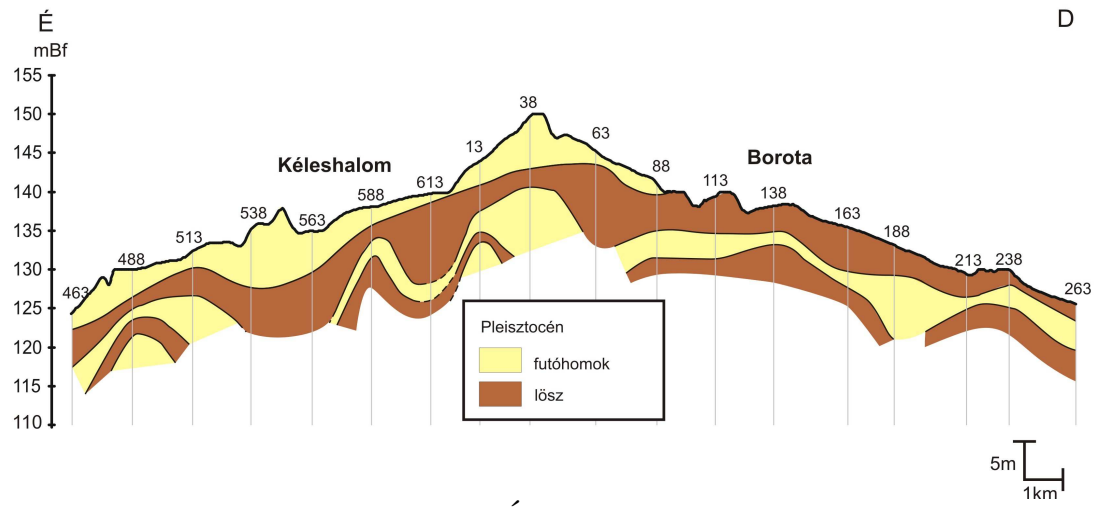

ÉD-7

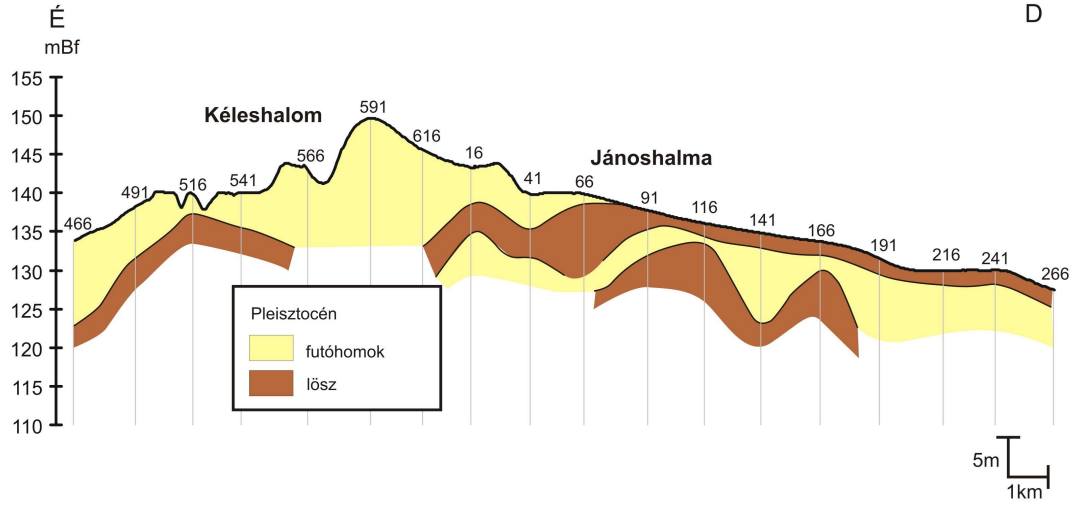

NYK-1

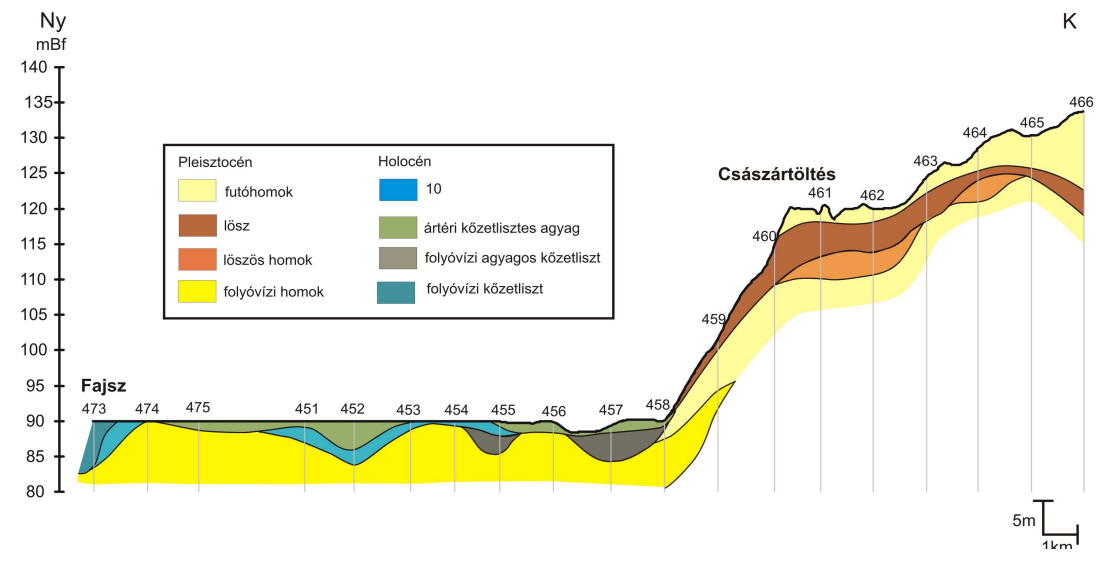


NYK-2
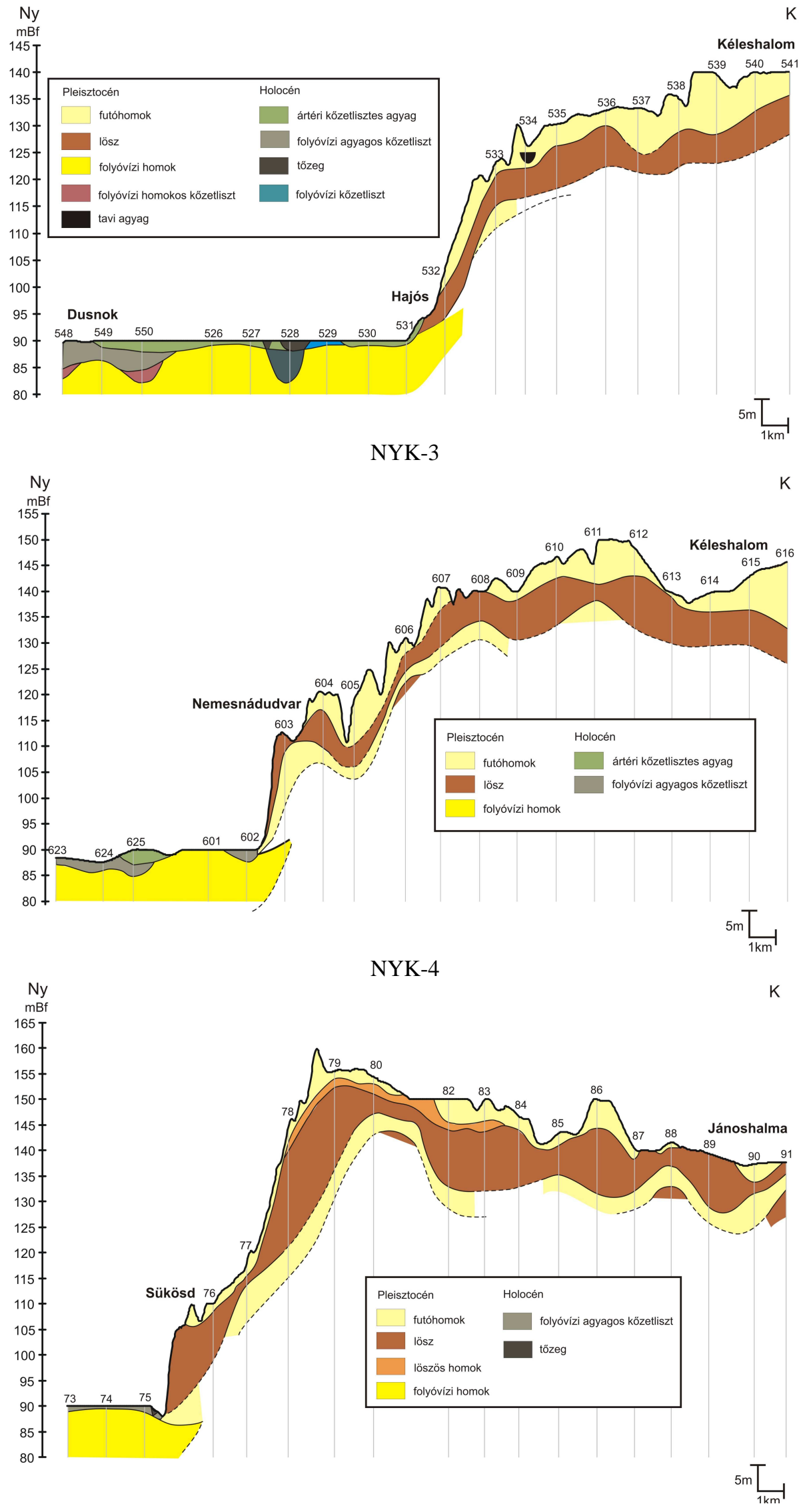
NYK-6

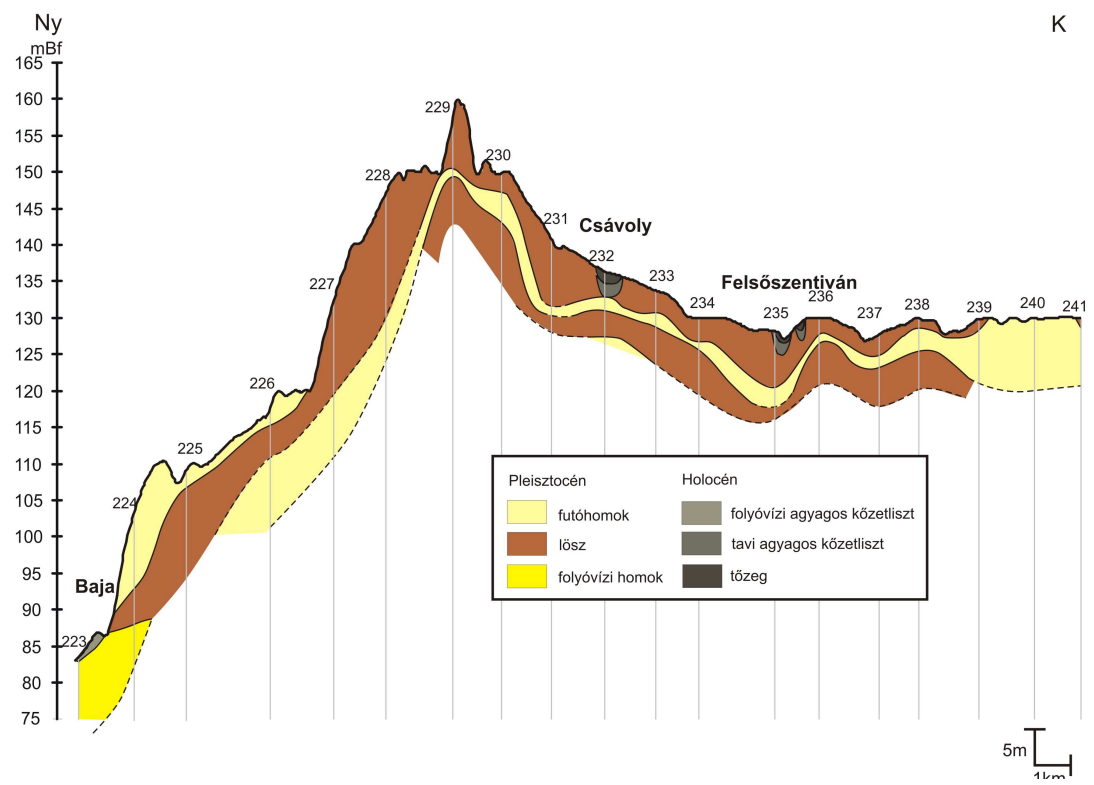

2. melléklet

A tájlehatárolások különbözöségei a szakirodalomban

a. természeti tájak rendszertani felosztása (Keresztesi et al. 1989)

b. a kistájak természeti adottságainak értékelése a szántóföldi növénytermelés szempontjából (Mezösi 1989)

c. a Marosi-Somogyi (1990), és a Dövényi (2010) féle kistájkataszterekben szereplö határvonal d. Marosi-Somogyi (1990) féle kistájkataszter térképmellékletében és a TAKI által digitalizált (Földrajzi kistájak é. n.) állományban szereplö Illancs határvonal e. Nebojszki (2004) által bemutatott kistájhatár

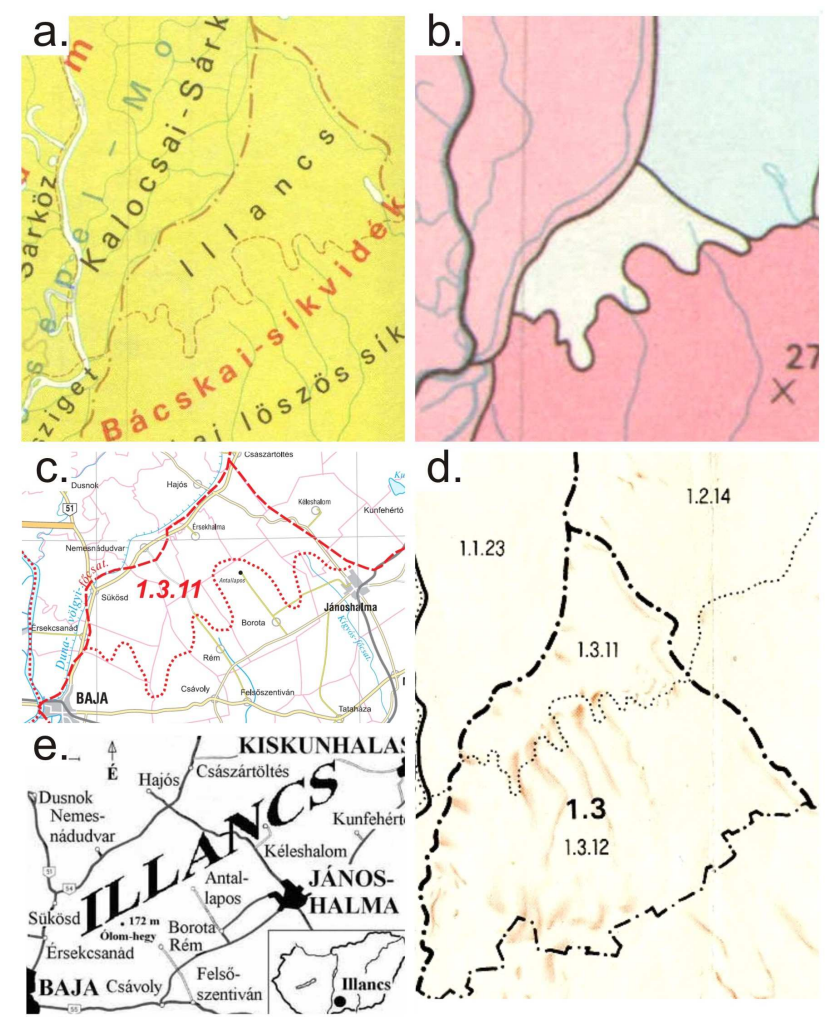




\section{3. melléklet}

Az Illancs a kutatásban pontosított (és vitatott) határai, valamint a vegetációs tájak, kiemelve a Homokhátságot, melynek az Illancs is része (Molnár et al. 2008)

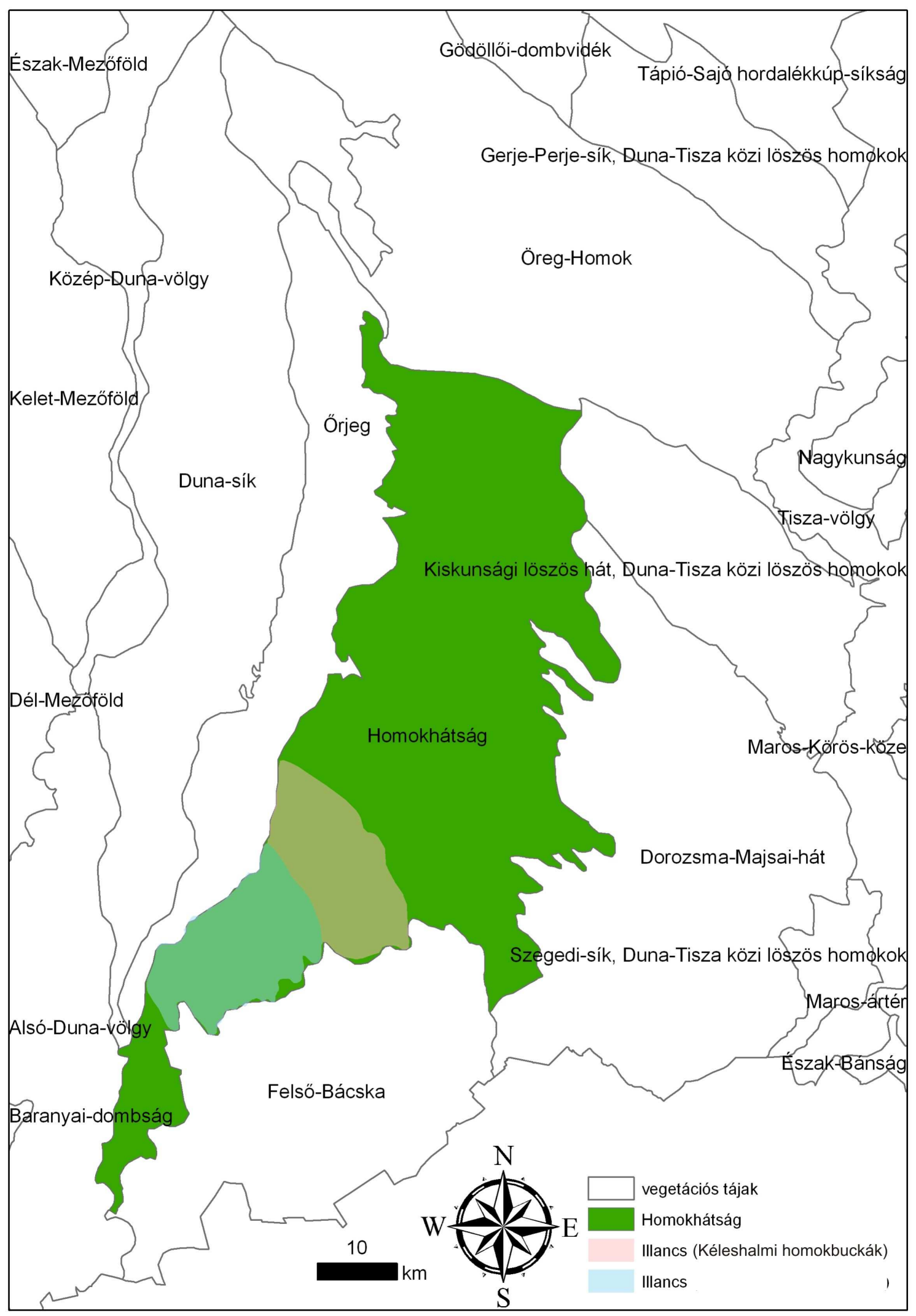




\section{4. melléklet}

\section{A kistáj különböző adottságú területei}

a. az Alföld földtani térképének kivágata (Rónai 1985)

sárga: futóhomok; barna: típusos lösz; szürke: infúziós lösz;

b. a talajok vízgazdálkodási tulajdonságai (Várallyay (1980)

1: igen nagy víznyelésủ és vízvezető képességü, gyenge vízraktározó képességü, igen gyengén víztartó talajok; 3: nagy víznyelésủ és vízvezető képességü, gyengén víztartó talajok, az egész szelvényben viszonylag egyenletes mechanikai összetétel mellett; 5: jó víznyelésű és vízvezető képességü, jó vízraktározó képességü, jó víztartó talajok, az egész szelvényben viszonylag egyenletes mechanikai összetétel mellett; 7: közepes víznyelésủ és vízvezető képességü, jó víztartó talajok, az egész szelvényben viszonylag egységes mechanikai összetétel mellett; 12: gyenge víznyelésủ, igen gyenge vízvezető képességü, erősen víztartó, kedvezőtlen vízgazdálkodású, szikes talajok; 13: gyenge víznyelésủ, igen gyenge vízvezető képességü, erősen víztartó, kedvezőtlen vízgazdálkodású, mélyben sós és/vagy szolonyeces talajok; 15: igen gyenge víznyelésủ, szélsőségesen gyenge vízvezető képességủ, igen erősen víztartó, igen kedvezőtlen, extrémen szélsőséges vízgazdálkodású, szikes talajok);

\section{c. Tájtípusok (Jakucs et al. 1989).}

10: mély talajvizü löszös síkság csernozjommal ;11: félig kötött buckás homokvidék, telepített erdökkel és homokpusztarét maradványokkal; 12: Kötött homokos síkság, mozaikosan homokpusztaréttel, akác- és nyárerdövel, szölö- és gyümölcsös kultúrákkal; 13: csernozjomos homoksíkság, kertészeti és szárazföldi hasznosítással; 14a: buckaközi medencék, magas vízállással, lápos réti illetve szikes réti talajokkal (zöld: ártéri síkság)

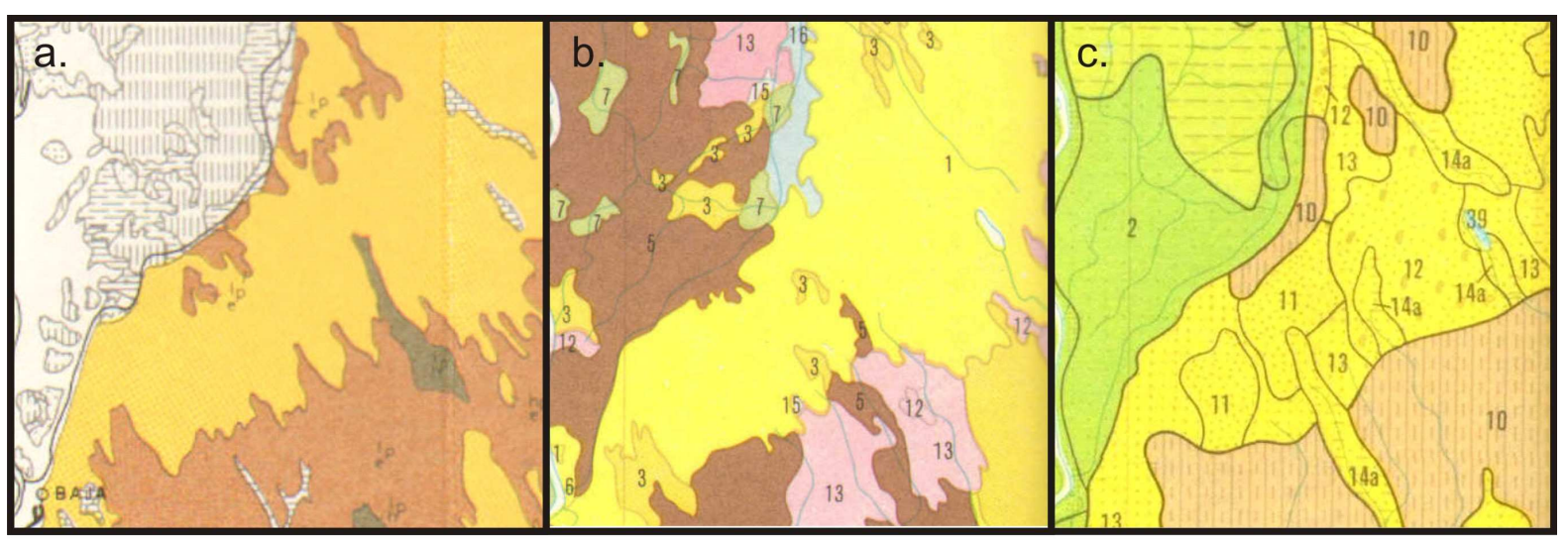

\section{5. melléklet}

\section{Az Illancs legmagasabb pontja, az Ólom-hegy (172 m) és környékének domborzatmodellje}

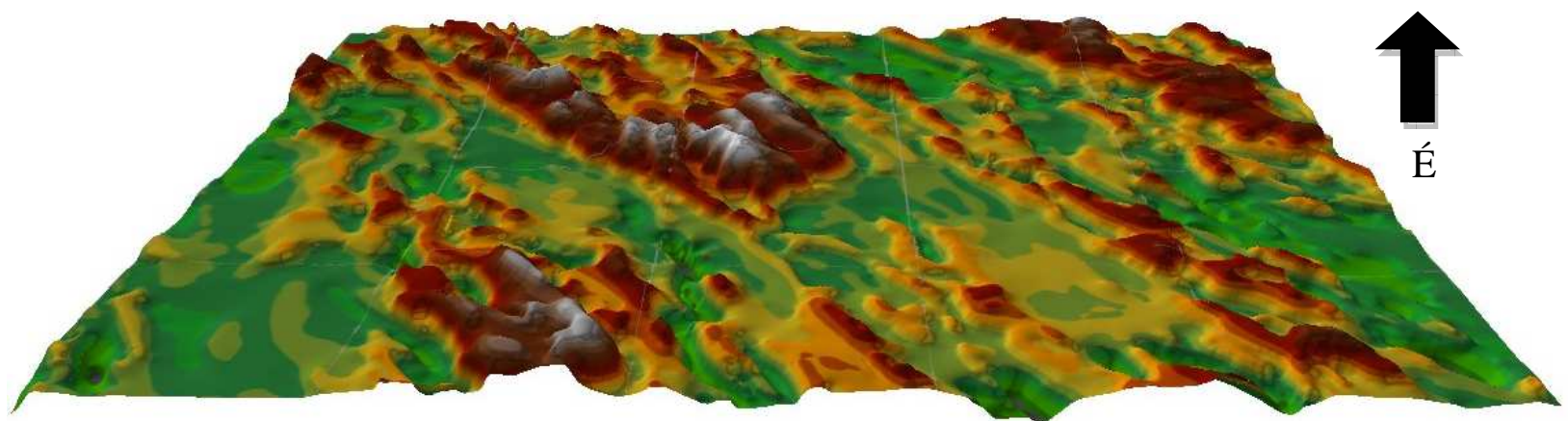




\section{6. melléklet \\ A dolgozatban megjelenö A-NÉR élőhelykategóriák rövid jellemzése \\ (Á-NÉR 2007, Bölöni et al. 2007)}

\section{B5 - Nem zsombékoló magassásrétek}

Legalább időszakosan vízzel borított, tápanyaggal jól ellátott termőhelyen kialakuló gyepes társulások, amelyekre jellemző, hogy a növényzet növekedése révén szembetünő felszíni egyenlötlenségek csak kivételesen jönnek létre. A növényzet alatt tőzegképződés rendszerint nem folyik. A domináns fajok a következők lehetnek: Carex acuta (=C. gracilis), C. acutiformis, C. disticha, C. melanostachya, C. otrubae (=C. cuprina), C. riparia, C. vesicaria, C. vulpina. Az idegenhonos (többnyire inváziós) fajok maximális aránya (amennyiben egyébként az élőhely egyértelmủen azonosítható) 50\%.

\section{D2 - Kékperjés rétek}

Nedves réti növénytársulások, amelyekben kékperje (Molinia) fajok uralkodnak. A talajvíz rendszerint nem éri el a felszínt. A talaj rendszerint erősen humuszos vagy tőzeges. Domináns lehet a Molinia hungarica vagy a Molinia arundinacea. Az idegenhonos (többnyire inváziós) fajok maximális aránya (amennyiben egyébként az élőhely egyértelmüen azonosítható) $50 \%$.

\section{F2 - Szikes rétek}

Magasfüvü, a vegetációs időszak kezdeti szakaszán átmenetileg vízzel borított rétek, melyek különböző mértékben szikesedett, illetve szikesedő (szolonyeces vagy szoloncsákos) réti talajokon alakulnak ki. Jellemző füfajaik: Agrostis stolonifera, Alopecurus pratensis, Beckmannia eruciformis, Glyceria fluitans subsp. poiformis, Alopecurus geniculatus, Festuca arundinacea, Elymus repens. Jellegzetesebb egyéb egysziküek: Carex distans, C. melanostachya, Juncus gerardii. A domináns egysziküeket a szikesekre jellemző kétsziküek kísérik, amelyek kaszálás után nagyban segítik az élőhely azonosítását.

\section{G1 - Nyílt homokpusztagyepek}

Alföldön, ritkábban dombvidéken, vagy hegylábon laza, humuszszegény homokon kialakult alacsony, maximálisan 75\%-os záródású, szárazságtűrő gyeptársulások. Domináns fajaik szárazságtűrő zsombékoló füvek. Állományaik korábban pusztai tölgyesekkel vagy nyáras-borókásokkal alkottak mozaikot. Az idegenhonos (többnyire inváziós) fajok maximális aránya (amennyiben egyébként az élőhely egyértelmüen azonosítható) 50\%.

\section{H5b - Homoki sztyeprétek}

Az alföldeken, homok alapkőzeten kialakult, humuszban gazdag talajok zárt szárazgyepjei. A gyepszint minimális záródása 50\%. Domináns füfajuk legtöbbször a Festuca wagneri, F. rupicola, Chrysopogon gryllus, Stipa capillata, Poa angustifolia, Bothriochloa ischaemum. Az idegenhonos (többnyire inváziós) fajok maximális aránya (amennyiben egyébként az élöhely egyértelmüen azonosítható) $50 \%$.

\section{OB - Jellegtelen üde gyepek és magaskórósok}

Jellegtelen üde gyepek és magaskórósok, amelyek a természetközeli élőhelyi kategóriákba nem sorolhatók be. A jellegtelenség oka és a terület eredete igen sokféle lehet. Ide tarozik pl. az ártéri és mocsári ruderális és félruderális gyomnövényzet, a hullámtéri liánosok, szedresek, a hullámtéri, gátmenti másodlagos, jellegtelen magaskórósok (Tanacetum, Cirsium, Chenopodium, Atriplex, Polygonum, Bidens, Rumex és Xanthium fajok) és jellegtelen üde rétek (Alopecurus, Dactylis, Agrostis, Agropyron fajok), továbbá az elgyomosodott, felhagyott üde legelők, a regenerálódó, korábban mütrágyázott vagy felülvetett kaszálók, a jelleg- 
telen, kiszáradó buckaközi élőhelyek, a Calamagrostis-os jellegtelen rétek. A 2-es természetességü, de élőhelyileg még azonosítható állományokat a megfelelö helyre soroljuk. Adventív fajokkal való borítása kisebb, mint $50 \%$. Az élőhely foltokban erősen gyomos is lehet.

\section{OC - Jellegtelen száraz- vagy félszáraz gyepek és magaskórósok}

Jellegtelen száraz- vagy félszáraz gyepek és magaskórósok, amelyek a természetközeli élőhelyi kategóriákba nem sorolhatók be. A jellegtelenség oka és a terület eredete igen sokféle lehet. Ide taroznak pl. a regenerálódó, régen felhagyott szántók, szőlők és gyümölcsösök gyepjei, a korábbi kezelésektől, mütrágyázástól, túllegeltetéstől, helytelen kaszálástól stb. eljellegtelenedett vagy elgyomosodott szárazabb kaszálók és legelök, a gátak, mezsgyék szárazgyepjei, az árvízvédelmi töltések és az azok mentén található szárazgyepek, a regenerálódó vetett szárazgyepek, a kunhalmok egy része, a régóta teljesen kiszáradt és befüvesedett csatornák, a száraz gyepeket, felhagyott szőlőket, mezsgyéket borító Calamagrostis és terresztris nád állományok, a tepelülésszéli zavart szárazgyepek, a szúrós gyomok által uralt legelőrészek, az alacsonyfüvü, fajszegény csillagpázsitos gyepek, a száraz csalánosok vagy a felhagyott foci- és golfpályák is. Az élőhely ritkásan cserjésedhet, a cserjék borítása nem éri el a 5\%-ot. A 2-es természetességű, de élőhelyileg még azonosítható állományokat a megfelelő helyre soroljuk. Adventív fajokkal való borítása kisebb, mint 50\%. Az élőhely foltokban erősen gyomos is lehet.

\section{OD - Lágyszárú özönfajok állományai}

Lágyszárú özönfajok (pl. Solidago, Aster, Helianthus fajok) által uralt területek. Az özönfajok borítása nagyobb, mint 50\%. Szükséges az elözönlött vegetációtípus hibridkategóriaként való feltüntetése. Ha csak özöngyomokból és gyomokból áll, természetességi értéke 1-es, a gyepfragmentumokkal mozaikoló állományok viszont 2-es értéket kapnak. 3-as természetesség nincs a kategórián belül.

\section{OG - Taposott gyomnövényzet és ruderális iszapnövényzet}

Erős taposással zavart területek egyszintü, többnyire alacsony, elfekvő növényzete, csupasz földfelszínek gyomvegetációja, valamint ruderális iszapnövényzete. Létrejöhet állattartó telepek udvarán, itatóhelyek környékén, tartósan vízzel borított vagy degradált, bolygatott felszíneken (belvizes szántók, libalegelők, vaditatók, dagonyázó helyek). Egyévesek dominálta, ruderális pionír növényzet. Jellemző fajok: Polygonum aviculare, Sclerochloa dura, Poa annua, Lolium perenne, Plantago major, Peplis portula, Echinochloa fajok. Ide tartoznak a vegetációval részben borított széles földutak is. Természetességi értéke 1-es. Nem tartoznak ide a törpekákás iszapnövényzettel borított területek (I1, I1N).

\section{J1a - Füzlápok, lápcserjések}

Lefolyástalan területeken és feltöltődőben levő morotvákban kialakult, cserjék (elsősorban a rekettyefüz) uralta, többé-kevésbé tőzeges talajú, gyakran fajszegény, lápi élőhelyek. Vizük állandóan pangó jellegü.

\section{P2b - Galagonyás-kökényes-borókás cserjések}

Általában a művelés felhagyása miatt - esetleg évszázadok múltán - cserjésedő egykori erdőterületek vagy erdő-gyep mozaikok. Az élőhelytípusnak az a lényege, hogy egy többnyire száraz (vagy kiszáradt) gyepes terület (kaszáló, legelö, esetleg emberi behatás által korábban kevéssé érintett sztyepterület) cserjésedni kezd és ennek hátterében szinte mindig közvetlen vagy közvetett kultúrhatást találunk. Így régi legelök többnyire másodlagos sztyepnövényzetének, felhagyott szőlők, gyümölcsösök lassú cserjésedése, leégett bokorerdők helyén visszaálló, az eredetihez képest módosult fajösszetételü (cserjék uralta) fás vegetációja ebbe a jelenségkörbe, illetve élőhelytípusba tartozik. A cserjék borítá- 
sa el kell érje a terület harmadát. A fák aránya kisebb 50\%-nál. Az idegenhonos cserjeés fafajok aránya kisebb 50\%-nál.

\section{M5 - Homoki borókás-nyárasok}

Ligetes megjelenésü, homoki gyepekkel mozaikos, cserjés vagy erdőformájú, kevés fajú és erdei fajokban szegény, boróka és / vagy fehér, illetve szürke nyár dominálta állományok az Alföld homokvidékein. Minimális záródása 20\%. Az idegenhonos fafajok maximális aránya (amennyiben egyébként az élőhely egyértelmüen azonosítható) 50\%.

\section{P8 - Vágásterüiletek}

Erdők, faállományok helyén, fakitermelést, erdőtüzet vagy egyéb természeti katasztrófát követően kialakult erdőtlen vagy már természetes vagy mesterséges újulattal rendelkező területek, ahol az újulat átlagos magassága a terület nagyobb részén nem éri el a fél m-t. Természetessége általában 1-es (olyan üres vágásterületek, ahol az eredeti élőhelyre jellemző lágyszárúak sincsenek jelen), 2-es (ha az eredeti erdő fás és lágyszárú fajai már vagy még kisebb mennyiségben jelen vannak) vagy ritkán 3-as (ha a vágásterületen mind a fiatal fák, mind a gyepszint alapvetően az eredeti élőhelyre jellemző).

\section{RA - Öshonos fajú facsoportok, fasorok, erdősávok}

Elszórtan álló idősebb őshonos fák, gyümölcsfák, dió, jegenyenyár alkotta, fasorok, erdősávok vagy facsoportok, melyek többnyire lágyszárú növényzet (gyep, mocsár, nádas) felett találhatók. A facsoportot legalább 5 nagyobb fa alkotja, minimális mellmagassági átmérő $25 \mathrm{~cm}$. Az erdőkategóriák minimális méretét vagy záródását nem éri el. Az idegenhonos fajokat tartalmazó állományok természetesége 2-es, az ezeket nem vagy alig tartalmazóké 3-as.

\section{S1 - Ültetett akácosok}

Akáccal létesített, többnyire elegyetlen, ültetvényszerü állományok, amelyek gyepszintje nagyobbrészt nem erdei, gyakran nitrofiton fajokból áll. Az akác (és az esetleg előforduló egyéb idegenhonos fafajok együttes) elegyaránya $75 \%$ feletti. Természetessége általában 1-es vagy ritkán, az eredeti élőhelyre jellemző aljnövényzet jelenlétében 2-es.

\section{S2 - Nemes nyárasok}

Nemes nyár fajtákkal, szabályos hálózatban létesített faültetvények, jellegtelen gyepszinttel. Az idegenhonos fafajok aránya $75 \%$ feletti. Természetessége általában 1-es vagy ritkán, a többnyire elöntést kapó területek „idős” (azaz nagy méretü fákból álló), régi fajták állományai esetében 2-es.

\section{S4 - Erdei- és feketefenyvesek}

Erdeifenyővel vagy feketefenyővel létesített többnyire elegyetlen, cserjeszint nélküli, száraz és laza talajokon álló, idősebb korban általában kiritkuló, ültetvényszerü állományok. A gyepszint a korábbi vegetáció maradványait őrizheti. A fenyők összesített elegyaránya $75 \%$ feletti. Természetessége általában 1-es vagy az eredeti élőhelyre jellemző aljnövényzet jelenlétében 2-es. Ahol az erdeifenyő őshonos (elsősorban a Nyugat-Dunántúlon), ott az eredeti élőhelyre jellemző, gazdag aljnövényzetü állományok természetessége 3-as.

\section{S6 - Nem őshonos fafajok spontán állományai}

Betelepített vagy behurcolt és agresszív módon terjedő fásszárú növényfajokból kialakult spontán erdők. Az idegenhonos fásszárúak aránya legalább 75\%. Szükséges az elözönlött erdőállomány hibridkategóriaként való feltüntetése (ha még felismerhető). Természetessége általában 1-es vagy ritkán, az eredeti élöhelyre jellemző aljnövényzet jelenlétében 2-es. 


\section{T1 - Egyéves, nagyüzemi szántóföldi kultúrák}

Tavaszi vagy öszi vetésủ egyéves nagyüzemi kultúrák vagy learatott helyük, rendszeresen szántott területek. T6-tól nem a táblaméret, hanem a művelés különíti el (fokozott mütrágyahasználat, vegyszerezés, gépesítés, az apróparcellás területeken nincsenek köztes mezsgyék és legfeljebb egy-két gyomfaj dominál). Az extenzív mủvelésủ egyéves szántóföldi kultúrák a T6-ba sorolandók. Természetessége általában 1-es, de a ritka, védendő gyomfajokkal bíró állományokat kettesnek tekintjük.

\section{U10 - Tanyák, családi gazdaságok}

Településektől elváltan található állandó vagy ideiglenes lakóépületek és állattartásra, borászatra stb. szolgáló épületek a körülöttük található udvarral, konyhakerttel, kisebb szőlő vagy gyümölcsfatelepítésekkel. Ide tartoznak a még nemrégiben felhagyott tanyák akkor, ha a rajtuk lévő épületek még jól felismerhetők. Természetessége 1-es. Nem ide tartoznak a régen felhagyott tanyahelyek, állattartóhelyek, amit a spontán regenerálódó vagy özöngyomosodó növényzet típusai szerint sorolunk be (pl. OC, RD, OD) 


\section{7. melléklet}

Illancs néhány védett növénye

a. tavaszi hérics (Adonis vernalis)

b. tarka sáfrány (Crocus reticulatus)

c. homoki árvalányhaj (Stipa borysthenica)

d. homoki bakszakáll (Tragopogon floccosus)

e. báránypirosító (Alkanna tinctoria)

f. fényes poloskamag (Corisperum nitidum)
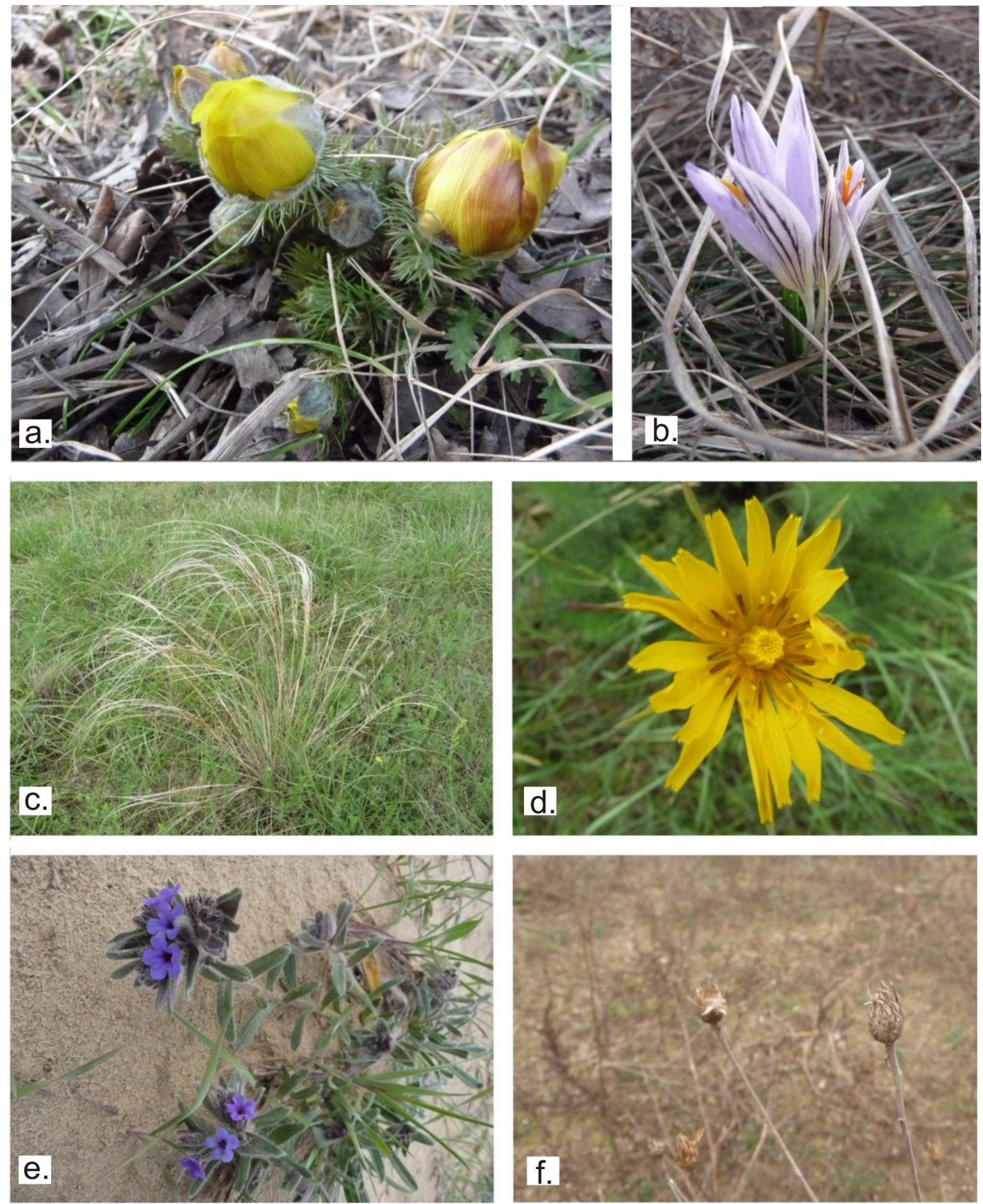
8. melléklet

A borotai rét vizsgált furatai (felülröl lefelé 1., 2., 3. furat) 


\section{9. melléklet \\ A felhasznált talajvizsgálati módszerek és eszközök}

\section{pH $\left(\mathrm{H}_{2} \mathrm{O}\right)$ (WTW inoLab pH 720)}

A talaj kémhatásának meghatározása elektroanalitikai eljárással történt, melynek alapja a különböző oldatokban elektródák segítségével mérhető feszültségkülönbség. Minden mintából 6-6 g talaj kimérését követően az egyik 6 g-ra $15 \mathrm{~cm}^{3}$ desztillált víz került, majd ezt 24 órás állás követte. A közvetlen mérés elött egy 4-es és egy 9-es pH-jú pufferoldattal állítottam be az elektródákat a mérési tartományba (MSZ-08-0206/2:1978 szabvány).

\section{Összes sótartalom (OK-104 Konduktométer)}

Légszáraz talajmintából ultradesztillált víz adagolásával a minták vízzel való telítését a képlékenység felső határáig végeztem. Az ismert kapacitású merülőelektródot a talajpépbe helyeztem, majd leolvastam a talajpép vezetőképességet millisiemensben (mS). Az MSZ08-0206-2:1978-as szabványban megadott táblázatba behelyesítve a vezetőképességet kaptam meg az összsótartalmat.

\section{$\mathrm{CaCO}_{3}$ tartalom (Scheibler-féle kalciméter)}

Az eljárás alapja a sósav és a kálcium-karbonát reakciója, mely eredményeképpen széndioxid keletkezik. A reakció során fejlődött szén-dioxid mennyiségéből kiszámítható a vizsgált talajminta mésztartalma a hőmérséklet és a légnyomás, mint módosító tényezők figyelembevételével (MSZ-08-0206/2:1978 szabvány).

\section{Fenolftalein lúgosság (Kézi titrálás)}

A szódában kifejezett fenolftalein-lúgosság mennyiségi meghatározásához 20 g talajmintát $200 \mathrm{ml}$ desztillált víz és $1 \mathrm{ml} 1 \%$-os fenol hozzáadása után összekevertem, majd 5 perc pihentetés után a részben kiülepedett, vörösre színezödött híg szuszpenzió tetejét óvatosan kevergetve 0,1 mol/l-es KHSO4-oldattal a megjelent vörös szín eltűnéséig gyors ütemben titráltam. A titráló oldat fogyásból számítottam vissza a minta szódában kifejezett fenolftalein-lúgosságát (MSz-08-0206/2-1978 szabvány)

\section{Kötöttség (Arany-féle kötöttség)}

A dörzsmozsárba helyezett $100 \mathrm{~g}$ talajra bürettából - pisztillussal történő folyamatos keverés mellett - desztillált vizet adagoltam. A desztillált víz hozzáadása mindaddig történt, míg a talajmassza el nem érte a képlékenység és a hígfolyósság határát, amely a fonalpróbával határozható meg (MSZ-08-0205:1978 szabvány).

\section{Szemcseméret eloszlás (Pipettás módszer)}

A talajminta előkészítése során elemi részecskékre diszpergált szuszpenziót készítettem. A talajszuszpenziót ülepítőhengerbe öntöttem, felkevertem, ülepedni hagytam és (a hőmérséklet függvényében) meghatározott időközönként $25 \mathrm{~cm}^{3}$ szuszpenziót pipettáztam ki. A talajszemcsék száraz tömegének meghatározása után, a szemcsék sürüségének ismeretében számítottam ki az egyes mechanikai frakciók (homok, por, agyag) \%-os mennyiségét (MSz-08-0205-1978).

\section{Humuszkoncentráció (Helios Gamma UV-VIS spektrofotométer)}

A talajmintákból 0,1-1 g közötti mennyiséget mértem ki a szervesanyag tartalom előzetes becslése alapján. A $100 \mathrm{~cm}^{3}$-es Erlenmeyer lombikban bemért talajhoz elöször $10 \mathrm{~cm}^{3}$ kálium-dikromát $\left(\mathrm{K}_{2} \mathrm{Cr}_{2} \mathrm{O}_{7}\right)$, majd $20 \mathrm{~cm}^{3}$ (96\%-os) kénsav $\left(\mathrm{H}_{2} \mathrm{SO}_{4}\right)$ hozzáadására került sor. 30 perces hütést követően $100 \mathrm{~cm}^{3}$ desztillált vizet adtam hozzá, majd a teljes leülepedésig (kb. 24 óra) állni hagytam. A dekantálást követően fotometráltam. A minták elött vakoldat mérésével állítottam be a müszert nullára, kiküszöbölve az oldószer, valamint a küvetta abszorbanciáját (MSZ 21470-52:1983) 
10. melléklet

A borotai mintaterület élőhelyeinek fajlistája

\begin{tabular}{|c|c|c|c|c|c|c|c|c|c|c|}
\hline \multicolumn{2}{|r|}{ Faj } & 1 & 1(é) & 2 & $3 / \mathbf{a}$ & $3 / \mathbf{b}$ & $3 / \mathrm{c}$ & 4 & 5 & HSZ \\
\hline Angol perje & Lolium perenne & & & & & & & & & + \\
\hline Apró szulák & Convolvulus arvensis & & & & & & & & & \\
\hline Aszúszegfü & Petrorhagia prolifera & + & + & & & + & & & & \\
\hline Betyárkóró & Erigeron canadensis & & + & & & & & & & \\
\hline Bókoló bogáncs & Carduus nutans & + & & + & + & + & + & + & + & + \\
\hline Csattogó szamóca & Fragaria viridis & & + & & & & & & & \\
\hline Csillagpázsit & Cynodon dactylon & & & & & & & & & + \\
\hline Csombormenta & Mentha pulegium & + & & + & & & & & & \\
\hline Csomós ebír & Dactylis glomerata & + & & & & + & & + & & + \\
\hline Ebszékfü & Matricaria maritima & & + & & & & & & & \\
\hline $\begin{array}{c}\text { Egybibés galago- } \\
\text { nya }\end{array}$ & $\begin{array}{l}\text { Crataegus } \\
\text { monogyna }\end{array}$ & & & + & & & & & & \\
\hline Egynyári seprence & Erigeron annuus & + & & + & & & & & & \\
\hline Fakó muhar & Setaria pumila & & & & & & & & & + \\
\hline Farkas kutyatej & $\begin{array}{l}\text { Euphorbia } \\
\text { cyparissias }\end{array}$ & + & + & & & & & & & \\
\hline Fehér here & Trifolium repens & + & + & & & & & + & + & + \\
\hline Fehér mécsvirág & Melandrium album & & & + & & & & & & \\
\hline Fehér pemetefü & Marrubium vulgare & + & & & & & & & & \\
\hline Fekete nadálytő & Symphytum officinale & & + & & & & & & & \\
\hline Gumós perje & Poa bulbosa & & & & + & & & & & \\
\hline Gyalogbodza & Sambucus ebulus & & & + & & & & & & \\
\hline $\begin{array}{l}\text { Hólyagos hab- } \\
\text { szegfü }\end{array}$ & Silene vulgaris & & + & & & + & & & & \\
\hline $\begin{array}{l}\text { Homoki fátyolvi- } \\
\text { rág }\end{array}$ & $\begin{array}{l}\text { Gypsophila fastigiata } \\
\text { L. subsp. arenaria }\end{array}$ & & + & & & & & & & \\
\hline Homoki pimpó & Potentilla arenaria & & & & & & & + & & + \\
\hline Kakukkfü & Thymus sp. & & + & & & & & + & + & \\
\hline Karcsú perje & Poa angustifolia & + & & & & & + & + & & \\
\hline Katángkóró & Cichorium intybus & & & & + & & & & + & \\
\hline $\begin{array}{l}\text { (nádképü) Kék- } \\
\text { perje }\end{array}$ & Molinia arundinacea & & & + & & & & + & & \\
\hline Komlós lucerna & Medicago lupulina & + & & & & + & + & & + & + \\
\hline Kötőkáka & $\begin{array}{l}\text { Schoenoplectus } \\
\text { tabernaemontani }\end{array}$ & + & & & & & & & & \\
\hline $\begin{array}{l}\text { Közönséges gyúj- } \\
\text { toványfü }\end{array}$ & Linaria vulgaris & & & + & & + & & & & \\
\hline Lándzsás útifü & Plantago lanceolata & & & & + & & & + & & + \\
\hline Mezei cickafark & Achillea collina & + & & + & + & + & + & + & + & + \\
\hline Mezei iringó & Eryngium campestre & & + & & & & & & & \\
\hline Mezei varfü & Knautia arvensis & & + & & & & & & & \\
\hline Nagy csalán & Urtica dioica & + & & & & & & & & \\
\hline Nádképü csenkesz & Festuca arundinacea & & & & & + & + & + & + & + \\
\hline Nagy bakszakál & Tragopogon dubius & & + & & & & & & & \\
\hline Orvosi somkóró & Melilitus officinalis & + & & & & & & & & \\
\hline
\end{tabular}




\begin{tabular}{|c|c|c|c|c|c|c|c|c|c|c|}
\hline Orvosi ziliz & Althaea officinalis & & & + & & + & & & & \\
\hline Parlagfü & $\begin{array}{c}\text { Ambrosia } \\
\text { artemisiifolia }\end{array}$ & + & + & & & & & & & \\
\hline Puha rozsnok & Bromus mollis & + & & & & & & & & \\
\hline Pusztai kutyatej & $\begin{array}{c}\text { Euphorbia } \\
\text { seguieriana }\end{array}$ & & & & + & & + & & & \\
\hline Réti imola & Centaurea jacea & & & & & & & + & & \\
\hline Selyemkóró & Asclepias syriaca & + & & + & & & & & & \\
\hline Siska nádtippan & $\begin{array}{c}\text { Calamagrostis } \\
\text { epigeios }\end{array}$ & & & & & & & + & & \\
\hline Sovány csenkesz & Festuca pseudovina & + & & & + & & & + & + & + \\
\hline Sziki cickafark & Achillea asplenifolia & + & & & + & + & + & + & & \\
\hline Sziki kerep & Lotus glaber & + & & & + & + & & + & + & \\
\hline Sziki szittyó & Juncus gerardii & & & & + & + & + & + & & \\
\hline Szürke káka & $\begin{array}{c}\text { Holoschoenus } \\
\text { romanus }\end{array}$ & & + & & & & & & & \\
\hline Szürke repcsény & Erysimum diffusum & & + & & + & & & & & \\
\hline Tarackos tippan & Agrostis stolonifera & & & & & + & + & & & + \\
\hline Tarackbúza & Agropyron repens & + & + & & + & & & + & + & \\
\hline Tarka koronafürt & Coronilla varia & & + & & & & & & & \\
\hline Tejoltó galaj & Galium verum & + & + & + & + & + & + & + & + & + \\
\hline Terjökekígyószisz & Echium vulgare & + & & & & & & & & \\
\hline Tövises iglice & Ononis spinosa & + & + & & & + & & & + & + \\
\hline Vadmurok & Daucus carota & + & & & & & & & & + \\
\hline Vajszínü ördög- & $\begin{array}{c}\text { Scabiosa ochrolence } \\
\text { szem }\end{array}$ & & + & & & & & & & \\
\hline Vasfü & Verbena officinalis & + & & & & + & & + & & + \\
\hline Vízi menta & Mentha aquatica & + & & & + & & & & & \\
\hline Vörös here & Trifolium pratense & + & + & & + & & & + & + & + \\
\hline
\end{tabular}




\section{1. melléklet}

A HegTOOL programhoz írt paraméterfile, mely a hdf-fileok különbözö rétegeiböl .tif kiterjesztésü file-okat készít, valamint a hozzá tartozó resample.bat file, amely a paraméterfilet felismeri és feldolgozását elindítja.

\section{NUM_RUNS $=1$}

BEGIN

INPUT_FILENAME $=$ D:LMODISL2001_0610-0625f1.hdf OBJECT_NAME $=$ MODIS_Grid_16DAY_250m_500m_VI

FIELD_NAME $=250 \mathrm{~m} 16$ days NDVI

BAND_NUMBER $=1$

SPATIAL_SUBSET_UL_CORNER $=(48.018 .5)$

SPATIAL_SUBSET_LR_CORNER $=(45.820 .5)$

RESAMPLING_TYPE $=$ NN

OUTPUT_PROJECTION_TYPE $=$ UTM

ELLIPSOID_CODE $=$ WGS84

$\mathrm{UTM} \mathrm{ZONE}=0$

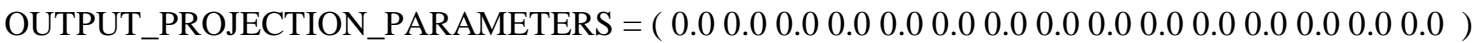

OUTPUT_PIXEL_SIZE $=231.656358$

OUTPUT_FILENAME = D:LMODISI2001_0610-0625f11.tif

OUTPUT_TYPE $=$ GEO

END

@echo off

rem $* * * * * * * * * * * * * * * * *$

rem * resample.bat $*$

rem $* * * * * * * * * * * * * * * * *$

rem

rem By Boudewijn van Leeuwen, Zsuzsanna Ladányi, 2008.07.16

rem Resamples Modis data according to a predefined parameter file.

resample.exe -p D:LMODIS \par2001_0610-0625f1.prm 
\# Project and scalefactor.py

\# Created by: Zsuzsi Ladányi \& Boudewijn van Leeuwen

\# Script to project the rasters, and multiplicate with the scale factor

\# Input parameter: A folder with Modis data in tif format

\# --

\# Import system modules and create the geoprocessor object

import sys, string, os, arcgisscripting

$\mathrm{gp}=$ arcgisscripting.create()

\# Check out any necessary licenses

gp.CheckOutExtension("spatial")

gp.overwriteoutput $=1$

\# Load toolboxes...

gp.AddToolbox("C:/Program Files/ArcGIS/ArcToolbox/Toolboxes/Spatial Analyst Tools.tbx")

gp.AddToolbox("C:/Program Files/ArcGIS/ArcToolbox/Toolboxes/Data Management Tools.tbx")

gp.addmessage ("A toolboxok futtatása " )

\# Get the parameter and set the working folder

\#inpath = sys.argv[0]

inpath = "D:IIMODIS \"

gp. Workspace $=$ inpath

outpath = "D:\\RESULT\"

\# Make a listing of all MODIS images

rasters = gp.ListRasters $(" * "$, "tif")

rasters.reset()

raster $=$ rasters.next ()

gp.addmessage ("A tif file-ok listájának készítése megtörtént... " )

\# For each image do:

while raster:

print raster

\# Declare variables:

totfile $=$ inpath + raster

gp.addmessage ("Feldolgozás alatt: " + totfile + "....")

\# print totfile

tempfile = outpath + "raster_temp.img"

\# Process: Single Output Map Algebra...

gp.Times_sa(totfile, "0,0001", tempfile)

\#gp.SingleOutputMapAlgebra_sa("totfile * 0,0001", tempfile,"")

\# Process: Project. ..

eov_out = outpath + raster.rstrip (".tif") + "_eov.tif"

gp.ProjectRaster_management(tempfile, eov_out,

"PROJCS['HD_1972_Egyseges_Orszagos_Vetuleti',GEOGCS['GCS_Hungarian_1972',DATUM['D_Hungari an_1972',SPHEROID['GRS_1967',6378160.0,298.247167427]],PRIMEM['Greenwich',0.0],UNIT['Degree',0. 0174532925199433]],PROJECTION['Hotine_Oblique_Mercator_Azimuth_Center'],PARAMETER['False_E asting',650000.0],PARAMETER['False_Northing',200000.0],PARAMETER['Scale_Factor',0.99993],PARA METER['Azimuth',90.0],PARAMETER['Longitude_Of_Center',19.048571778],PARAMETER['Latitude_Of _Center',47.14439372222],UNIT['Meter',1.0]];IsHighPrecision", "NEAREST", "250",

"Hungarian_1972_To_WGS_1984_2", "",

"PROJCS['WGS_1984_UTM_Zone_34N',GEOGCS['GCS_WGS_1984',DATUM['D_WGS_1984',SPHERO ID['WGS_1984',6378137.0,298.257223563]],PRIMEM['Greenwich',0.0],UNIT['Degree',0.01745329251994 33]],PROJECTION['Transverse_Mercator'],PARAMETER['False_Easting',500000.0],PARAMETER['False_ Northing',0.0],PARAMETER['Central_Meridian',21.0],PARAMETER['Scale_Factor',0.9996],PARAMETER ['Latitude_Of_Origin',0.0],UNIT['Meter',1.0]];-5120900 -9998100

450445547,391054;\#;\#;0,001;\#;\#;IsHighPrecision")

gp.AddMessage(eov_out + " kész!!")

\# print eov_out + " kész!!"

raster $=$ rasters.next () 
Statisztikai elemzések raszteres képállományokra egy adott könyvtárból, az eredmények táblázatos megjelenítése

\#

\# Zonalstatistics as table.py

\# Created by: Zsuzsi Ladányi

\# Script to make zonal statistics on a raster, resulting in a table

\# Input parameter: A folder with Modis data in tif format

\#

\# Import system modules and create the geoprocessor object import sys, string, os, arcgisscripting

$\mathrm{gp}=$ arcgisscripting.create ()

\# Check out any necessary licenses

gp.CheckOutExtension("spatial")

gp.overwriteoutput $=1$

\# Load toolboxes...

gp.AddToolbox("C:/Program Files/ArcGIS/ArcToolbox/Toolboxes/Spatial Analyst Tools.tbx")

gp.AddToolbox("C:/Program Files/ArcGIS/ArcToolbox/Toolboxes/Data Management Tools.tbx")

gp.addmessage ("A toolboxok futtatása " )

\# Get the parameter and set the working folder

\#inpath = sys.argv[0]

inpath = "D:\\ADATOK\\"

gp. Workspace $=$ inpath

outpath = "D:IIRESULT\"

\# Make a listing of all MODIS images

rasters = gp.ListRasters("*","tif")

rasters.reset()

raster $=$ rasters.next ()

gp.addmessage ("A tif file-ok listájának készítése megtörtént... " )

\# For each image do:

while raster:

print raster

\# Declare variables:

vegso_tablazat $=$ outpath + raster.rstrip $("$.tif") + "_zonal.dbf"

erdok_Illancs = "d:IIBIOMASSZAII erdofoltok_Illancs.img"

\# Process: Zonal Statistics as Table...

gp.ZonalStatisticsAsTable_sa(erdok_Illancs, "VALUE", raster, vegso_tablazat, "DATA")

raster $=$ rasters.next () 
14. melléklet

A vegetációs indexek lefutása 2000-2008 között

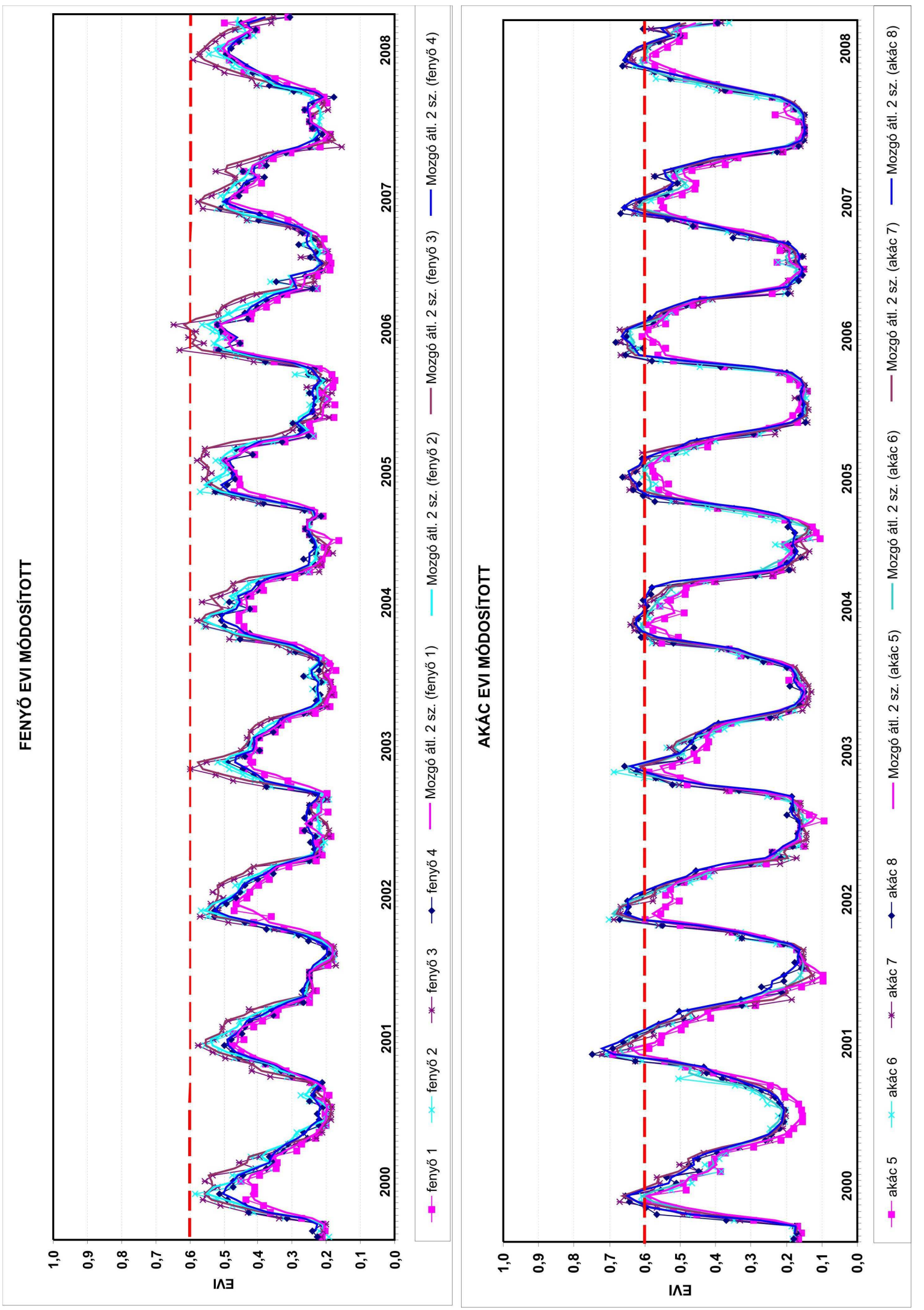


15. melléklet

Gemenc biomassza-produkciója a vizsgált években (2000-2009)

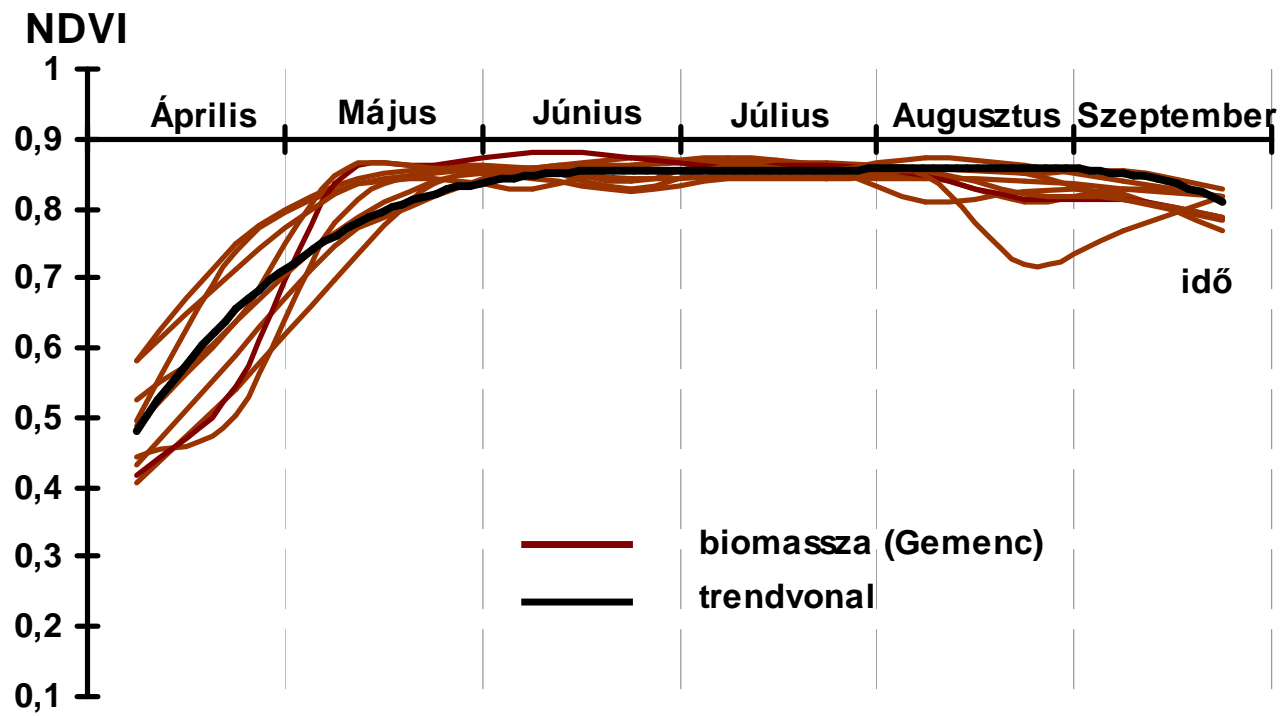




\begin{tabular}{|l|l|l|l|}
\cline { 2 - 3 } Kérdôiv & Telepiilés & Nerme: & Eletkora: \\
& Idốport: & & gazdálkodó \\
\hline & & hobbikertész \\
\hline & nem gazdálkodik \\
\hline
\end{tabular}

1. 1. On szerint kevesebb csapadék van ez az utóbbi évtizedekber, azaz a szárzodás folyamata érzékelhetỗ-e a Duna-Tisza közén?

2. Megfigyelt-e változást a kömyezố területek vízborításaban az 1980-s évek óta?

Ha iger, mit:

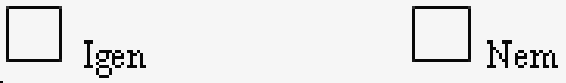

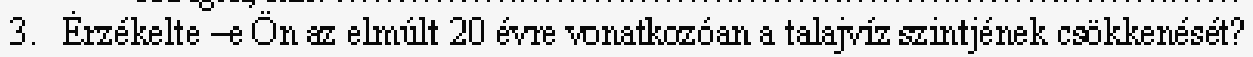

4. Becsülje meg a talajviz szintjének coökkenését!

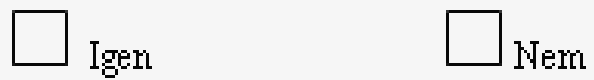

Vagy mit gondol, mennyit változott a talajvíz szintje a településen az 1980-s évekhez viszonyitva?

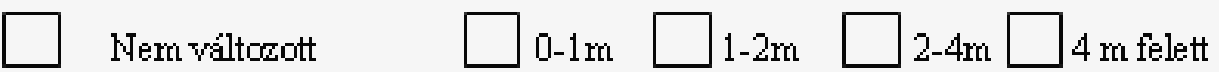

Ha több:

5. Ha On vagy csalártagjai foglalkoznak mezôgazdasággal, befolyásolta-e a gazdálkodását a vízhiány és a talajvíz szirtjének csökkenése?<smiles>CCN(C)C1CCC1</smiles>

$\mathrm{Ha}$ nem, akkor milyen növényt termesst:

6. Rákényszerïlt-e mứvelési ág-váltásra az elmúlt évtizedelben?

Ha igen, akkor mely növény helyett termel és rit

Nerm

7. Okoz-e károkat, többletköltségeket a vizhiáry a mezốgazdasági termelésben?

8. Öntöz-e?

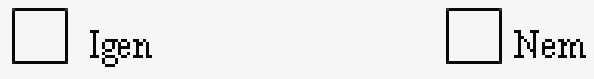

Ha igen, akkor használ-e modem technikát:

9. Ha érzékel problémát, On milyen javaslatot terne megoldására:

10. Tapasztalt-e a kömyezetében arra példát, hogy a vízhiány miatti terméskiesés miatt hagytak parlagon terïleteket, illetve ezen okból költöztek el a terïletrốl az emberek?<smiles>C1C[AsH2]C1</smiles>

11. Ön mben látná a terület vízhiányának megoldását?

$\square$ viztánozók építése mưvelési ág váltás rendszeres csatomatisztitás vizkivétel mélyebb rétegekbồl vizutárpoótlás a Tiszaboól és a Dunaboól nincs megoldás 